\author{
UNIVERSIDADE DE SÃO PAULO \\ FACULDADE DE FILOSOFIA, LETRAS E CIÊNCIAS HUMANAS \\ DEPARTAMENTO DE HISTÓRIA \\ PROGRAMA DE PÓS-GRADUAÇÃO EM HISTÓRIA SOCIAL
}

JOSÉ HENRIQUE BORTOLUCI

\title{
Pensamento Eurocêntrico, Modernidade e Periferia: Reflexões sobre o Brasil e o Mundo Muçulmano
}

São Paulo 
UNIVERSIDADE DE SÃO PAULO

FACULDADE DE FILOSOFIA, LETRAS E CIÊNCIAS HUMANAS

DEPARTAMENTO DE HISTÓRIA

PROGRAMA DE PÓS-GRADUAÇÃO EM HISTÓRIA SOCIAL

\title{
Pensamento Eurocêntrico, Modernidade e Periferia: Reflexões sobre o Brasil e o Mundo Muçulmano
}

\author{
José Henrique Bortoluci
}

Dissertação apresentada ao Programa de Pós-Graduação em História Social do Departamento de História da Faculdade de Filosofia, Letras e Ciências Humanas da Universidade de São Paulo, para a obtenção do título de Mestre em História.

Orientador: Prof. Dr. Peter R. Demant 
BORTOLUCI, José Henrique. Pensamento Eurocêntrico, Modernidade e Periferia: Reflexões sobre o Brasil e o Mundo Muçulmano. Dissertação apresentada ao Programa de Pós-Graduação em História Social do Departamento de História da Faculdade de Filosofia, Letras e Ciências Humanas da Universidade de São Paulo, para a obtenção do título de Mestre em História.

\section{E-mail: jhbortoluci@yahoo.com.br}

Aprovado em:

Banca Examinadora

Prof. Dr. Instituição:

Julgamento: Assinatura:

Prof. Dr. Instituição:

Julgamento: Assinatura:

Prof. Dr. Instituição:

Julgamento: Assinatura: 
O Haiti é aqui

O Haiti não é aqui

Caetano Veloso e Gilberto Gil

A partir das margens ou das periferias, as estruturas de poder e de saber são mais visíveis.

Boaventura de Sousa Santos 


\section{Resumo}

BORTOLUCI, J. H. Pensamento Eurocêntrico, Modernidade e Periferia: Reflexões sobre o Brasil e o Mundo Muçulmano. 2009. 221 f. Dissertação (Mestrado). Faculdade de Filosofia, Letras e Ciências Humanas, Universidade de São Paulo, São Paulo.

$\mathrm{Na}$ recente literatura em Ciências Sociais, o paradigma eurocêntrico da modernidade vem sofrendo ataques de diferentes naturezas. Entretanto, esse paradigma ainda fornece as categorias e formas de pensar hegemônicas para a análise sobre a modernidade e os obstáculos a ela, em sociedades periféricas. Este trabalho busca analisar o "setor sociológico" de uma estrutura de atitudes e referências eurocêntricas e as apropriações deste para a reflexão sobre os dilemas da modernidade, no Brasil e nas sociedades muçulmanas. A partir disso, busca-se avançar na crítica a esse paradigma eurocêntrico, por meio de um diálogo interparadigmática pós-colonial - este entendida como um programa de estudos críticos à modernidade, elaborado a partir de um ponto de vista periférico. Por fim, pretende-se mostrar que uma série de elementos dessas abordagens antieurocêntricas estão presentes em análises históricas e sociológicas acerca da modernidade no Brasil e nas sociedades árabes e muçulmanas.

Palavras-Chave: Modernidade. Eurocentrismo. Periferia. Brasil. Mundo Muçulmano.

\section{Abstract}

BORTOLUCl, J. H. Eurocentric Thought, Modernity and Periphery: Reflections on Brazil and the Muslim World. 2009. $221 \mathrm{f}$. Dissertação (Mestrado). Faculdade de Filosofia, Letras e Ciências Humanas, Universidade de São Paulo, São Paulo.

The Eurocentric paradigm of modernity has been suffering several kinds of attacks in the recent literature of Social Sciences. Nevertheless, such paradigm still provides the hegemonic categories and structures of thought for the reflection about modernity and the obstacles imposed to it in peripheral societies. This work intends to analyze the "sociological sector" of a eurocentric structure of attitudes and references, and the appropriations of such structure for reflections about the dilemmas of modernity, in Brazil and in Muslim societies. Furthermore, it intends to advance a criticism about that eurocentric paradigm, by means of an interparadigmatic postcolonial dialogue - such a dialogue understood as a programme of critical studies on modernity, formulated from a peripheral point of view. Finally, this work tries to demonstrate that many elements of those anti-eurocentric approaches are present in historical and sociological analysis about modernity in Brazil and in Arab and Muslim societies.

Keywords: Modernity. Eurocentrism. Periphery. Brazil. Muslim World. 


\section{SUMÁRIO}

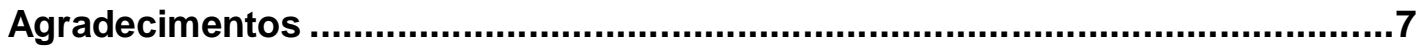

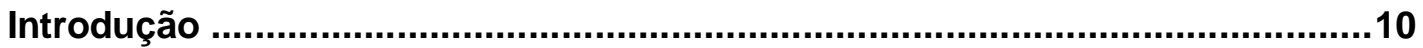

1. Formas e categorias do pensar eurocêntrico ...........................................15

Orientalismo e Eurocentrismo ........................................................... 15

Uma teoria do poder: a tradição do "Despotismo Oriental" ..........................31

Racionalização e conduta de vida metódica ..............................................41

Internalismo culturalista e "história imóvel" ..............................................46

2. Pensamento Eurocêntrico e os dilemas da modernidade no Brasil e nas sociedades árabes e muçulmanas......................................................................52

Eurocentrismo e o Mundo Árabe e Muçulmano ........................................56

Discursos eurocêntricos e o desafio do moderno no Brasil..........................80

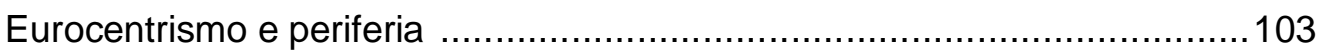

3. Modernidade, crítica ao eurocentrismo e o problema da modernidade periférica........................................................................................................... 107

Elementos da razão eurocêntrica ..................................................... 107

Modernidade e Ocidente............................................................. 115

Uma tentativa de inserir a diversidade: a abordagem das múltiplas

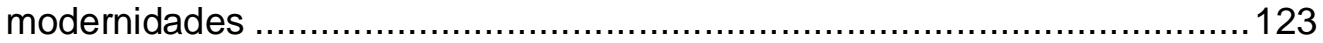

Para além das Múltiplas Modernidades: diálogos teóricos por uma teoria crítica da modernidade a partir da periferia

4. As sociedades árabes e muçulmanas: modernidade periférica como simbiose do arcaico e do moderno......................................................................158

5. Marxismo dialético brasileiro e a busca da especificidade da modernidade periférica................................................................................................................. 176

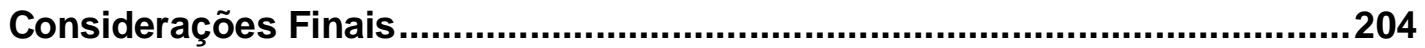

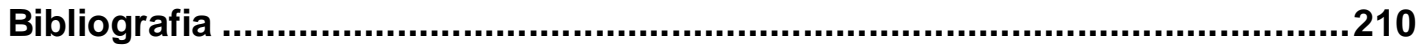




\section{Agradecimentos}

A imagem mais corriqueira que se tem de um pesquisador na área de Ciências Humanas - mesmo daquele que apenas começa e engatinhar por essa vida - é uma imagem de solidão: as longas horas em frente a um amontoado de livros, textos e notas, em uma biblioteca ou gabinete, com a companhia discreta da quinta ou sexta xícara de café do dia. Essa imagem, reveladora de um comportamento comumente entendido como adequado, parece ser o índice de validade do trabalho desse pesquisador: uma vez que não dispomos de laboratórios onde podemos aplicar e replicar nossos experimentos, o trabalho constante e solitário aparece como um dos únicos garantidores de que aquela pesquisa é algo sério e não um desperdício de tempo com diletantismo vazio.

Esse sentimento de mergulho solitário deve marcar, creio eu, a experiência da maioria dos que se iniciam pelas bandas da pesquisa. Aprendemos desde o início que os prazos devem ser cumpridos, que só se dá conta da bibliografia com trabalho obstinado, que temos que delimitar nossos objetos (que terror...) e que a dissertação não se escreve da noite pro dia. Vamos aprendendo, como dizia o mestre Florestan Fernandes, que ciência é trabalho - e trabalho duro.

Contudo, essa imagem do aprendiz de pesquisador solitário, mergulhado em seus livros, esconde uma realidade fundamental: só é possível pensar, produzir e crescer coletivamente. Se o trabalho individual e constante tem uma importância crucial - e é evidente que ele tem -, estou muito seguro de que ele só ganha sentido quando serve como maneira de sintetizar vivências e aprendizados que são coletivos.

Entendo este trabalho como a síntese dessas muitas experiências coletivas de que tive a felicidade de fazer parte, sobretudo nos últimos seis anos de minha vida, desde que ingressei no curso de Relações Internacionais, na Universidade de São Paulo. Ali, pude conhecer pessoas excepcionais e participar de inúmeros espaços de formação. Com essas pessoas e nesses espaços, aprendi, entre tantas outras coisas, que a vida intelectual só vale a pena se ela aponta para um processo de humanização que vá muito além de uma aquisição individual de habilidades, conhecimentos ou títulos. Uma humanização que parte de uma insatisfação brutal com o estado de coisas e com a mais do que comum passividade acadêmica frente 
a elas; mas que entende que apenas com uma prática política e dialógica constante pode-se tentar chegar - coletivamente, mais uma vez - a um mundo em que todos tenham a chance de transpor a fronteira entre o "ser e o ser mais", nas palavras de Paulo Freire.

Muitos me acompanharam neste breve percurso, até aqui. Agradeço, inicialmente, ao Professor Peter Demant - meu orientador desde 2003, quando comecei meu primeiro projeto de iniciação científica. Sua dedicação ao meu desenvolvimento acadêmico foi de importância fundamental. Além disso, agradeço pelo seu humanismo e sua capacidade de discordar respeitosamente, sem nunca ter expressado nenhuma exigência de que seus pontos de vista e opiniões determinassem, por menos que fosse, minhas conclusões.

Os professores Paulo Daniel Farah e Gildo Marçal Brandão, membros de minha banca de qualificação, desempenharam um papel muito importante para a elaboração deste trabalho. Também tive o prazer e a oportunidade de cursar, no meu primeiro semestre de mestrado, uma disciplina sobre o pensamento político brasileiro com o professor Gildo, fundamental em uma fase em que os problemas aqui apresentados estavam ainda em uma primeira etapa de maturação. Agradeço também aos professores Bernardo Ricupero, Jessé Souza e Sérgio Costa, com quem tive a oportunidade de discutir alguns dos temas aqui apresentados, em diferentes ocasiões.

Agradeço à Fapesp pelo financiamento desta pesquisa, entre março de 2007 e fevereiro de 2009. Aproveito para agradecer imensamente a cada uma das pessoas que me auxiliaram ao longo destes anos, para que minha formação universitária fosse possível ou menos penosa - em particular ao meu primo Geraldo, ao meu tio Carlos, aos Srs. Baltazar S. Parra e Durval Mangilli, e à família Watanabe.

Agradeço a cada aluno com quem dividi uma sala de aula na Fundação Escola de Comércio Álvares Penteado (FECAP), onde tive a satisfação de lecionar ao longo destes dois anos e meio, principalmente no Bacharelado em Relações Internacionais. Agradeço igualmente aos meus colegas naquela instituição, em particular aos coordenadores do Bacharelado, Cláudia e Glauco, pelas oportunidades e pelo companheirismo. 
A lista de amigos que me acompanharam até aqui é muito grande, e certamente há um pouco de cada um deles neste trabalho. Não irei nomeá-los um a um - já que com isso corro o sério risco de me esquecer de pessoas fundamentais -, mas apenas lembrar de algumas pessoas que estiveram comigo em momentos e espaços fundamentais.

Agradeço aos meus colegas da turma de 2006 do Bacharelado em Relações Internacionais: são tantas as pessoas entre estas por quem sinto carinho e gratidão, que tenho apenas a lamentar que nossos encontros sejam cada vez mais raros. Aos grandes amigos de Jaú, meu recanto, responsáveis por muito do que sou - e por continuarem sendo pessoas tão especiais.

Sou eternamente grato aos meus grandes amigos da "Veredas" - em particular aos muito queridos Tassia, Ernesto, Fatah, Talita e Sarah -, companheiros de gestão Centro Acadêmico de Relações Internacionais no ano de 2004, com quem pude ir vivenciando um "sentimento do mundo", desde então. Sentimento esse que foi explorado, aprofundado e recriado pelos amigos da "Terceira Margem" - é uma felicidade conviver com pessoas brilhantes e especiais como o Gabriel, a Andreza, o Léo, o Thiago, o Sérgio, a Cris, a Nádia, a Lu e, de forma especial, o Jonas e o Caio - amigos sinceros, a quem tanto devo.

Participei, com muitos desses e outros amigos e companheiros, de um grupo de estudos sobre teorias do imperialismo e sociologia paulista, ao longo dos últimos dois anos. Talvez não seja preciso dizer que este trabalho tem uma dívida imensa com todos esses "imperialistas" - sobretudo o capítulo 5, que é fruto direto de nossas discussões conjuntas.

Ao João Paulo, responsável por momentos quase diários de alegria - um amigo precioso, de quem tenho a imensa sorte de ser irmão.

À Melina, por me tornar alguém melhor e renovar minhas esperanças a cada dia - vamos de mãos dadas.

Aos meus pais, meus grandes mestres, Dirce e José (Didi) - a quem humildemente dedico este trabalho. A eles, devo absolutamente tudo. 


\section{Introdução}

Na capa da edição 2047 da revista Veja, de 13 de fevereiro de 2008, somos confrontados com uma imagem que, a princípio, deixa pouco espaço para dúvidas e exige poucos esforços de raciocínio. Vemos ali uma espécie de gênio da lâmpada, ou um sultão brasileiro. O membro da "elite burocrática" do governo federal - como indica a manchete - flutua em seu tapete voador, este estampado como um cartão de crédito. Em sua cabeça, um turbante:

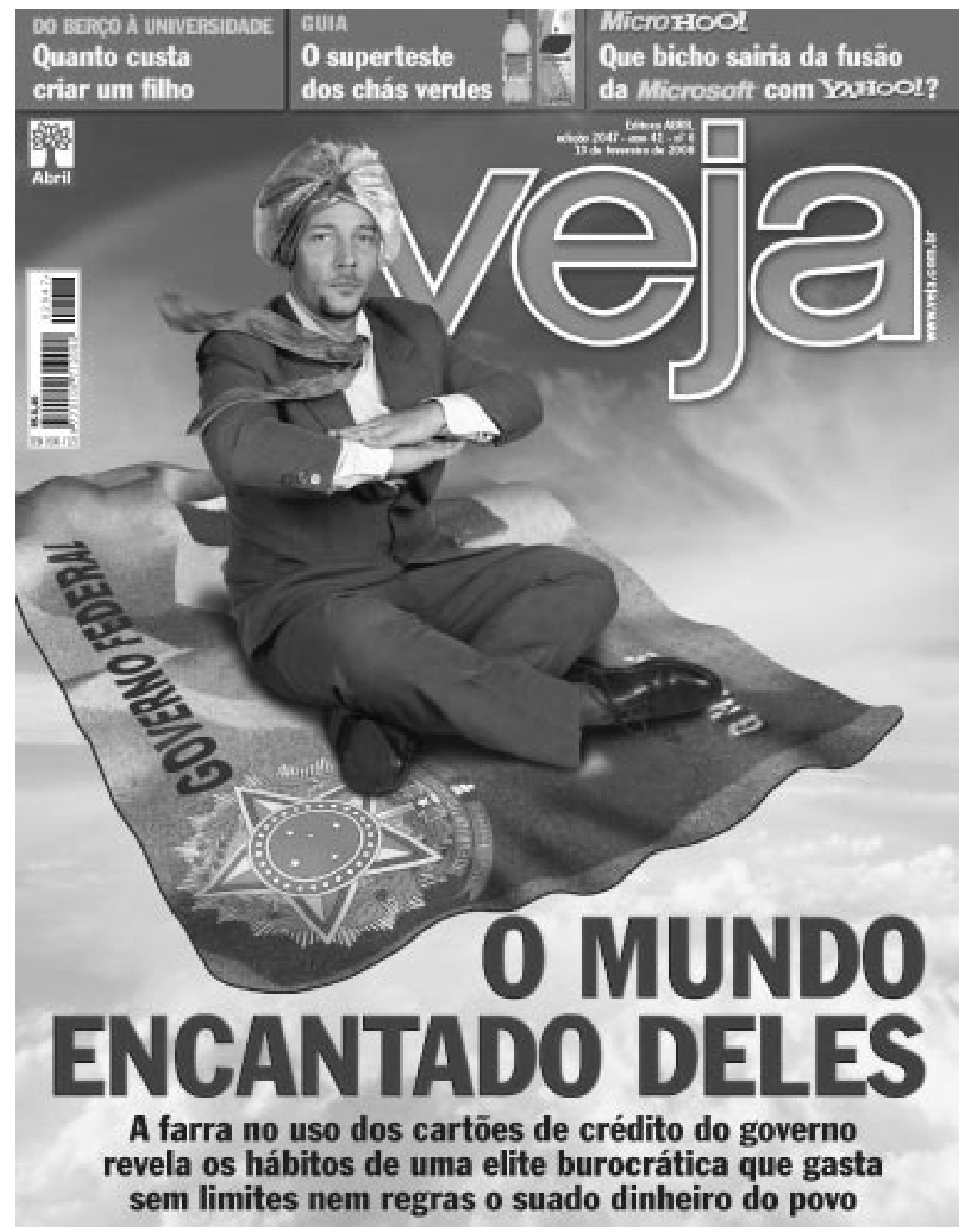


O tapete voador, o turbante e a posição dos braços daquele membro exemplar da elite burocrática brasileira remetem ao universo mágico das Mil e uma Noites. Ela traz à mente as imagens, histórias e encantos de um outro mundo. Um mundo de odaliscas e sultões, de haréns, desertos, encantos e mistério. Um mundo que não é o das modernas burocracias ocidentais - apesar do fato de o nosso personagem vestir um terno, traje que, na imagética ocidental, remete a uma posição masculina de respeito e autoridade. Os elementos do exótico, evidentemente, ganham preeminência frente ao elemento frágil, que é esse enganoso terno.

Não haveria, então, como disfarçar: essa elite à oriental nada teria a ver com o mundo racionalizado dos aparatos de estado e do capitalismo ocidentais.

Essa elite é própria a um mundo encantado - ou seja, um mundo que não se "desencantou", como Weber nos ensina sobre o processo de racionalização por que passaram as modernas sociedades ocidentais. Um mundo preso à tradição, à magia, às relações pessoais e familiares, onde o gozo imediato vale mais que a lógica do trabalho e do ascetismo. Um mundo em que a casa tem precedência sobre a rua e em que o estado terá constituído a sociedade, e não o contrário. Um estado que é tudo, enquanto a sociedade não é nada.

A revista nos ensina qual é o padrão de comportamento dessa elite burocrática: com seus hábitos irresponsáveis, sua propensão à "farra", nada condizente com valores republicanos ou ascéticos, essa elite burocrática gastaria ao seu bel-prazer todo o dinheiro suado do povo. Esse grupo desponta como a fonte dos males que assolam a sociedade brasileira. Ela é a responsável pelo atraso do país, é o obstáculo à mudança. Vivem em um mundo encantado e impedem que a sociedade se desencante. Esses "donos do poder" comporiam o estamento anti-moderno, que impede que as ondas progressistas da modernização se alastrem pelo tecido social. Localizam-se no topo, pairam sobre as nuvens, longe de qualquer controle ou contato com a sociedade.

O círculo proposto por essa imagem vai se fechando. Ela oferece, a todos aqueles que passam os olhos pela capa da revista, uma porta de entrada para uma "interpretação do Brasil" - e, mais do que isso, para um conceito de modernidade e de modernização. A operação parece se dar em dois níveis: primeiramente, essa elite é descrita como "oriental"; ao mesmo tempo, o "oriental" é subentendido como 
tudo aquilo que se afasta do moderno - e, assim, do racional, do aceitável e do justo. Portanto, um "Brasil oriental" equivaleria a um "Brasil não moderno", ou seja, a um país atrasado, dominado por uma elite governamental corrupta, distante do povo, da sociedade.

Um Brasil incompleto, que ainda não teria "chegado lá" - "lá", onde chegaram as modernas sociedades ocidentais. Por ainda aguardar na sala de espera da história, acompanhado das outras nações atrasadas, a crônica de seu destino só poderia ser narrada pela negativa - sua história se reporia continuamente, marcada por um fatídico ainda não.

Essas operações, pressupostas pela imagem oferecida pela revista, não são triviais, óbvias ou necessárias. Elas se assentam, pelo contrário, em uma narrativa hegemônica da modernidade e de seus "outros". Uma narrativa que se foi constituindo simultaneamente à constituição da própria idéia de Ocidente e de seu contato com povos coloniais ou com os impérios orientais, e que depois foi apropriada de formas diversas para a compreensão sobre os destinos históricos de sociedades periféricas - e não apenas do Brasil, evidentemente. Na história do pensamento social dessas nações, os esforços de autocompreensão corresponderam (e correspondem), com extrema freqüência, a um exercício de comparação com aquilo que, supostamente, teria se constituído nas "modernas sociedades ocidentais". Mas essas imagens sobre o moderno e o não moderno também povoam o imaginário cotidiano, os discursos do senso comum e são, com imensa freqüência, mobilizados pelos meios de comunicação dessas sociedades ou de "estados ocidentais modernos", quando buscam representá-los.

Essa narrativa eurocêntrica da modernidade - que corresponde à autoimagem hegemônica do centro hegemônico do sistema-mundo moderno - e as alternativas teóricas a ela são os objetos centrais deste trabalho. Procuro nele analisar, em particular, como essa forma de ver a modernidade, própria ao discurso eurocêntrico, leva a que as histórias das sociedades periféricas sejam narradas sob o signo da incompletude ou do fracasso, cuja culpa normalmente é atribuída a 
traços internos de cada uma dessas sociedades, os quais funcionariam como bloqueios ao processo de modernização.

Parto, para isso, de um diálogo crítico com várias vertentes do que se convencionou chamar de Estudos Pós-Coloniais, Descoloniais, Culturais e Subalternos. Esses trabalhos fornecem, de início, uma espécie de enquadramento geral de problemas e perspectivas, a partir das quais busquei propor leituras, aproximações e confrontações com outras tradições teóricas, seja para criticá-las ou para enquadrá-las no interior de um possível programa anti-eurocêntrico. Nesse sentido, não procuro me filiar a nenhuma teoria particular nem desenvolver uma perspectiva teórica original, mas, seguindo algumas trilhas que vêm sendo desbravadas em uma série de teorias críticas contemporâneas e por estudos históricos e sociológicos sobre o Brasil e as sociedades muçulmanas, apontar para possíveis diálogos que sirvam àquele programa inter-paradigmático e interdisciplinar a que acabei de me referir.

No capítulo inicial, parto de uma crítica ao primeiro modelo anti-eurocêntrico elaborado por Edward Said, em a Orientalismo (1978). Busco mostrar, em seguida, como alguns trabalhos pós-coloniais posteriores buscaram solucionar os dilemas desta obra, permitindo que seus "insights" teóricos pudessem ganhar maior precisão conceitual e potencial crítico. A partir dessa primeira consideração, discorro brevemente sobre a constituição de uma estrutura de atitudes e referências eurocêntricas e, sobretudo, de um setor sociológico dessa estrutura, em alguns momentos fundamentais do moderno pensamento social.

A seguir, no capítulo 2, busco mostrar como aquela estrutura foi apropriada, de formas diversas, para uma reflexão sobre os obstáculos à modernidade, no Brasil e nas sociedades muçulmanas. Para isso, concentro-me em alguns autores representativos, tanto clássicos quanto contemporâneos, que desenvolveram interpretações gerais sobre a história e a estrutura social dessas sociedades, a partir de diferentes apropriações daquela estrutura de atitudes e referências eurocêntricas.

No capítulo 3, procuro realizar uma crítica a esse paradigma eurocêntrico, sobretudo pelas limitações e mistificações que impõe para uma análise da modernidade em sociedades periféricas. Procuro analisar brevemente uma série de perspectivas teóricas - e particularmente a perspectiva das Múltiplas Modernidades, 
os Estudos Pós-Coloniais e trabalhos da tradição marxista -, tentando delinear alguns elementos de um programa teórico crítico à modernidade periférica que seja, ao mesmo tempo, um programa crítico à modernidade, elaborado a partir de um "ponto de vista periférico".

Por fim, nos capítulos 4 e 5, procuro mostrar que as questões apontadas no capítulo 3 encontram um espaço fundamental em uma série de análises históricas e sociológicas que buscaram enfrentar os desafios colocados pelo paradigma eurocêntrico. No caso das sociedades árabes e muçulmanas, apresento algumas das leituras sobre a simbiose entre o "arcaico e o moderno" na constituição dessas modernidades periféricas e pós-coloniais. No caso do Brasil, foco-me nas contribuições do "marxismo dialético" brasileiro, em particular dos estudos históricos, sociológicos e literários derivados de uma "intuição de Brasil”, originada no conhecido "Seminário d'O Capital', a partir de fins dos anos 1950, na Faculdade de Filosofia da Universidade de São Paulo. Em ambos os casos, procuro mostrar a necessidade do diálogo entre uma agenda teórica direcionada a uma teoria crítica da modernidade periférica e o pensamento social desenvolvido em nações periféricas. 


\section{Formas e categorias do pensar eurocêntrico}

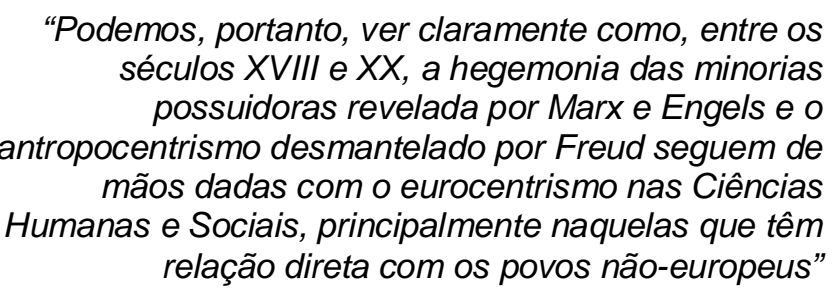

Anouar Abdel-Malek, $1975^{1}$

\section{Orientalismo e Eurocentrismo}

O conceito de "orientalismo" adquiriu notoriedade (e, é preciso dizer, forte caráter pejorativo) nas ciências sociais a partir de 1978, com o lançamento do livro Orientalism, de Edward Said. Até então, o termo não era visto de forma depreciativa, sendo geralmente utilizado para caracterizar estudos sobre o Oriente desenvolvidos por pesquisadores e instituições ocidentais. Said, um intelectual palestino radicado nos Estados Unidos, desenvolve naquele livro uma ampla análise da produção cultural e teórica européia (sobretudo francesa e inglesa) acerca do Oriente que teria constituído a "tradição orientalista", alvo de suas profundas críticas.

$\mathrm{Na}$ verdade, a crítica ao pensamento eurocêntrico ou orientalista nas academias centrais é anterior ao livro de Said, tendo ocupado espaço já nas décadas de 60 e 70, estimulada, sobretudo, pelos processos de independência nacional no terceiro mundo e articulada principalmente em linguagem e conceitos marxistas - as obras de Anouar Abdel-Malek e Maxime Rodinson estão entre as mais representativas desse conjunto de trabalhos. Além disso, Said e os estudos pós-coloniais posteriores ajudaram a popularizar, na academia ocidental, uma tradição anti-eurocêntrica que, no século $X X$, teve como notáveis representantes pensadores da descolonização e da negritude, em geral advindos de regiões periféricas e apresentando em suas biografias alguma forma de envolvimento em

\footnotetext{
${ }^{1}$ Citado em Wallerstein (2007: 68).
} 
lutas anti-racistas ou pela descolonização - nomes como Frantz Fanon, C.L.R. James, Aimé Césaire e Amílcar Cabral saltam à mente ${ }^{2}$.

Com Said, a crítica ao orientalismo não ganha apenas notoriedade, mas passa a sofrer uma profunda influência do pensamento estruturalista e pósestruturalista francês - sobretudo das análises de discurso e da reflexão sobre a constituição de mecanismos de poder enredados em tramas discursivas, desenvolvidas por Michel Foucault. Desde a década de 1970, tornou-se quase uma moda incontornável nos setores críticos da academia norte-americana a referência ao pensamento de autores como Foucault, Derrida e Lyotard, nas diversas áreas das Humanidades. Não é exagero notar que Said é um dos precursores e um dos mais influentes promotores dessa apropriação do pensamento francês contemporâneo pela academia norte-americana. Os chamados Estudos póscoloniais são, em grande medida, um capítulo desse processo de apropriação.

Para Said, o orientalismo é um estilo de pensamento baseado em uma distinção epistemológica e ontológica entre o "Ocidente e o Oriente". Essa distinção fundamental seria o ponto de partida para a elaboração de teorias, romances, obras de arte e outras peças culturais sobre o Oriente, seus povos e costumes (Said, 2003: 2). Porém, o orientalismo não constituiria apenas uma forma de representação: essa duplicação do discurso (Oriente versus Ocidente) própria ao Orientalismo seria marcada de uma pretensão de estereotipar o outro - no caso, o outro do discurso, o Oriente - e de reduzi-lo a uma determinada essência. 0

2 Entretanto, nem sempre os recentes estudos pós-coloniais reconhecem-se como continuadores de uma espécie de linhagem político-teórica que remonta ao pensamento radical anticolonial ou anti-racista. Como aponta Bart Moore-Gilmort (1997: 15), apenas em meados da década de 80 Said teria reconhecido a existência de trabalhos predecessores ao seu no tipo de crítica que ele buscava avançar. O mesmo pode ser dito de Gayatri Spivak e Homi Bhabha que, juntos de Said, vieram se firmando como a tríade maior dos estudos pós-coloniais - dando a entender, em diversos momentos, que a origem de suas reflexões se assenta muito mais firmemente na "alta cultura ocidental" do que no pensamento e na ação de homens e mulheres em disputa contra o legado da colonização. Contudo, parece-me que essa é uma tendência que, felizmente, vem se enfraquecendo: os textos de autores pós-coloniais, subalternos e da área de Estudos Culturais parecem vir abrindo espaço, nos anos recentes, para uma retomada do legado daqueles pensadores antes tidos como "políticos" ou "anti-acadêmicos", ao menos nas academias centrais -, sem o abandono de autores críticos e da tradição do "alto humanismo" ocidentais. Creio que essa mudança pode ser observada, por exemplo, na própria obra de Said: este autor, a partir da década de 1990 e, em especial, em Cultura e Imperialismo (1993), voltou-se em grande medida para as "vozes emergentes" e "contra-discursos subalternos" em situações coloniais e pós-coloniais, como veremos à frente. 
orientalismo ter-se-ia desenvolvido como um estilo ocidental de dominar, reestruturar e exercer autoridade sobre o Oriente (Said, 2003: 3).

Said tenta mostrar que o orientalismo não é uma fantasia etérea da Europa sobre o Oriente, mas sim um grande corpo teórico e prático em que houve, por diversas gerações (sobretudo, ao longo dos séculos XVIII e XIX, mas com repercussões que chegam até nossos dias), um considerável investimento material. Tendo tido seus principais elementos desenvolvidos ao longo do enfrentamento europeu contra o Oriente em sua expansão econômica e militar, o orientalismo seria uma dimensão considerável da cultura política e intelectual moderna (Said, 2003: 12) - no interior da qual, convém afirmar, desenvolveram-se os principais discursos sociológicos sobre a modernidade.

O próprio Said afirma que o uso do termo "orientalismo" para a produção contemporânea refere-se às formas pelas quais cientistas sociais e produtores culturais nutrem-se de elementos do discurso orientalista original europeu, dos séculos XVIII e XIX ${ }^{3}$ (Said, 2003: 19). O conceito de discurso é central para a compreensão da abordagem geral de Said em Orientalismo, assim como para uma reflexão sobre esse processo de "nutrição" teórica.

Como afirma Stuart Hall, refletindo sobre o legado teórico de Said, um discurso orientalista é uma forma particular de representar o "Ocidente", o "Resto (não-Ocidente)" e a relação entre eles. Um discurso é um grupo de afirmações que constituem uma forma de "representar" um tipo particular de objeto. O próprio conceito de discurso não se basearia na distinção convencional entre pensamento e ação, linguagem e prática: a idéia de discurso refere-se à produção de conhecimento a partir da linguagem; mas ele próprio é produzido por uma prática, ou seja, a prática de se produzir sentido (Hall, 1992: 291). Dessa forma, o conceito de discurso orientalista pode ser entendido como uma série de formas de representação concatenadas logicamente, que fornecem a base categorial e o domínio analítico a partir do qual se desenvolvem esforços de compreensão de realidades sociais tidas como não-ocidentais. O núcleo articulador desse discurso é uma distinção entre o desenvolvimento das sociedades ocidentais (tido como "normal" ou "clássico") e o desenvolvimento das outras sociedades: o Oriente

${ }^{3}$ Aliás, como bem mostram Perry Anderson e Norberto Bobbio, mesmo essa produção dos três últimos séculos nutre-se de categorias gestadas ao menos desde Aristóteles. Umm bom exemplo disso é a história do conceito de "despotismo oriental", de que tratarei mais à frente (Anderson, 1985; Bobbio, 1996). 
("estagnado, irracional e atrasado") é "construído" como um contraste, um "outro" a partir do qual se pode caracterizar o próprio Ocidente ("dinâmico, racional e progressista") (Turner, 1994: 96). É de se observar que, no interior desse discurso, o conceito de Oriente não é necessariamente geográfico: ele delimita, sobretudo, uma fronteira entre o "nós" (Ocidente) e o "eles" (não-Ocidente), "no interior de uma relação que produz e reproduz o outro como inferior, ao mesmo tempo em que permite definir o nós, o si mesmo, em oposição a este outro...” (Costa, 2006: 119).

Dessa forma, a crítica ao orientalismo, popularizada por Said, mas desenvolvida anterior e posteriormente por uma série de autores, é, sobretudo, um método de desconstrução de essencialismos. Para efetuar essa crítica, o que se deve observar em uma determinada produção teórica não é somente, segundo Said, a sua fidelidade ao original representado, mas o estilo de abordagem, as figuras de linguagem, as estruturas categoriais e os mecanismos narrativos (Said, 2003: 20-21).

Nas últimas três décadas, poucas obras nas áreas de Ciências Sociais e Humanidades despertaram maior polêmica em todo o mundo do que Orientalismo. O livro, por seus avanços e, principalmente, pela imensidão de caminhos abertos a novas investigações empíricas e teóricas, produziu clivagens acadêmicas e ascendeu disputas ferinas entre críticos de todos os tipos. Não é meu objetivo aqui realizar uma revisão das recepções de Orientalismo, nem mesmo elencar sistematicamente as possíveis críticas à obra ${ }^{4}$. Entretanto, é preciso apontar que esse primeiro esquema anti-eurocêntrico saidiano - como quase toda corajosa peça de interferência no debate acadêmico - possui algumas fragilidades na forma de constituir suas categorias fundamentais e de abordar os materiais utilizados; essas insuficiências constituem desafios a uma crítica a discursos eurocêntricos que se proponha a analisar textos de naturezas diversas, produzidos em diferentes contextos.

Nota-se, inicialmente, que é bastante vacilante a forma como Said trata a relação entre discurso orientalista e imperialismo ao longo do livro. Apesar de estabelecer uma ligação entre ambos, Said parece oscilar entre uma consideração da determinação discursiva sobre o mundo material ("o orientalismo gera o imperialismo") e o oposto (“o imperialismo gera o orientalismo”). É muito provável

\footnotetext{
${ }^{4}$ Para isso, remeto a Moore-Gilbert (1997) e Demant (2007).
} 
que o autor não assumiria nenhuma dessas alternativas: a própria noção de discurso, da forma como ele a apresenta, restringe tal tipo de simplificação. Entretanto, não são poucas as vezes em que Said parece fornecer uma espécie de autonomia ao setor discursivo dos instrumentos de dominação, que faz com que sua categoria de "orientalismo" resvale na imagem de uma enteléquia histórica: o "Orientalismo", estrutura sem sujeito, geraria um Oriente a serviço de um Ocidente dominador ${ }^{5}$. Essa espécie de determinação estrutural do discurso orientalista leva a que Said construa uma imagem unitária do orientalismo: ele parece abarcar tudo, munido de uma potência (quase) auto-sustentável.

Essa forma de descrever o orientalismo deve-se, em grande parte, ao uso particular que faz Said dos trabalhos em que Foucault desenvolve de forma mais acabada suas análises de discurso e sua abordagem da constituição da "episteme" ocidental - em especial As palavras e as coisas (1966) e A Arqueologia do Saber (1969) -, além de livros em que Foucault descreve a constituição de dispositivos de controle ocidental e a forma como estes servem à constituição da subjetividade moderna, como Vigiar e Punir (1975).

A influência de Foucault nessa primeira fase de estudos de Said acerca dos discursos ocidentais sobre o Oriente é notável, a ponto de nos convidar ao questionamento de outras possibilidades, não declaradas no texto de Said, de paralelo entre as obras. Como exemplo disso, não seria descabido sugerir que o estudo "arqueológico" de Said sobre os discursos acerca do Oriente obedece a uma lógica comparável aos estudos de Foucault sobre a loucura e a internação, sobretudo a História da Loucura (1961). Se em A palavra e as coisas o pensador francês buscava reconstituir a arqueologia da razão moderna, naquele trabalho ele voltava-se à compreensão das formas pelas quais a cultura européia moderna se constituiu a partir de um mecanismo de exclusão, pela definição de áreas, em particular a "loucura", nas quais ela não mais se efetivaria - apesar de tais áreas terem sido constituídas por essa própria cultura. Trata-se, em síntese, de uma

\footnotetext{
${ }^{5}$ Outro problema, menos importante para os objetivos deste trabalho, é a dúvida sempre presente na escrita de Said sobre sua crença na existência do Oriente. Said oscila entre a idéia de que "o Ocidente cria o Oriente" e de que "o Ocidente representa falsamente o Oriente" - aproximando o "orientalismo", nesta segunda formulação, da idéia de "ideologia", como tratada na tradição marxista (Moore-Gilbert, 1997). Entre os diversos motivos dessa oscilação, é comum apontar-se que Said ainda não haveria conseguido, nessa obra, combinar de forma não contraditória suas referências marxistas (sobretudo Gramsci) e pósestruturalistas (Foucault).
} 
história do "outro da razão", indissociável de uma história do "mesmo da razão". Sem desenvolver aqui essa questão, diria que Said, voltando-se para a constituição de uma forma diferente de "outro da razão européia", realiza um esforço em muitos aspectos comparável de reconstrução das tramas de discurso e poder que deram origem às formas fundamentais da moderna subjetividade européia.

Centremo-nos aqui, contudo, na apropriação das análises de discurso e das considerações epistemológicas de Foucault realizada por Said. Nas palavras do próprio Said:

"I have found it useful here to employ Michel Foucault's notion of a discourse, as described by him in The Archeology of Knowledge and Discipline and Punish, to identify Orientalism. My contention is that without examining Orientalism as a discourse one cannot possibly understand the enormously systematic discipline by which European culture was able to manage - and even produce - the Orient politically, sociologically, militarily, ideologically scientifically, and imaginatively during the post-Enlightenment period. Moreover, so authoritative a position did Orientalism have that I believe no one writing, thinking or acting on the Orient could do so without taking account of the limitations on thought and action imposed by Orientalism" (Said, 2003: 3).

Essa forma de descrever o orientalismo como fornecedor das condições de possibilidade do conhecimento e da ação sobre o Oriente parece-me amplamente baseada na idéia foucaultiana de "episteme". Tal conceito, em Foucault, é fundamental para suas reflexões sobre as possibilidades do conhecimento e sobre a constituição das disciplinas ocidentais. A episteme é a concatenação de práticas discursivas de uma determinada época, dotada de regras e condições a partir das quais o próprio conhecimento se torna possível. Foucault descreve a episteme como o espaço “...onde os conhecimento, encarados fora de qualquer critério referente a seu valor racional ou a suas formas objetivas, enraízam sua positividade e manifestam assim uma história que não é a de sua perfeição crescente, mas, antes, a de suas condições de possibilidade" (Foucault, 2007: XVIII; destaque meu). 
Nesse sentido, o orientalismo, apesar de restrito a um determinado setor da experiência ocidental ${ }^{6}$, forneceria, para Said, as condições de possibilidade de todo conhecimento e de toda prática direcionados àquela entidade à qual o Ocidente se contrapunha. Ele poderia ser lido como o fundamento de racionalidade de qualquer elaboração intelectual, artística ou política que tematizasse aqueles povos ou regiões. De forma geral, essa idéia sobre a operação do orientalismo baseia-se amplamente em uma concepção igualmente foucaultiana sobre as formas de operação do poder: este, disseminado socialmente, constituiria os objetos do conhecimento. Em síntese, Said busca mostrar, em Orientalismo, a constituição de um "Oriente discursivo" como contraponto a um Ocidente em constituição, ou seja, a constituição de um discurso que mediaria ou ordenaria logicamente a relação entre Ocidente e Oriente (Moore-Gilbert, 1997: 38). Independentemente se "simpáticos" ou não com relação ao Oriente, os discursos ordenados a partir do discurso orientalista seriam dominados por uma vontade de potência do Ocidente sobre o Oriente - este seria descrito como essencialmente sem voz, sensual, feminino, despótico, irracional e atrasado, sendo o Ocidente o seu negativo.

Não é grande surpresa apontar que Orientalismo recebeu críticas muito próximas àquelas feitas ao estruturalismo e ao pós-estruturalismo em geral, como as que já apresentamos acima. O alvo fundamental é a própria categoria de

${ }^{6}$ Certamente, o orientalismo é um conceito muito mais restrito que o de episteme. Com este, Foucault, sobretudo em As Palavras e as Coisas - provavelmente seu texto mais marcado pelo estruturalismo e, segundo comentaristas, a obra síntese desse movimento intelectual (ver Dosse, 2007: cap. 34) - procurou descrever a constituição da episteme moderna como aquela que fornecia o solo para qualquer conhecimento: "Numa cultura e num dado momento, nunca há mais de uma epistémê, que define as condições de possibilidade de todo saber. Tanto aquele que se manifesta numa teoria quanto aquele que é silenciosamente investido numa prática" (Foucault, 2007: 230). Contudo, a forma como Said opera esse conceito para a área específica dos estudos sobre o Oriente assemelha-se muito ao esforço de Foucault. É de se observar que o "orientalismo", como descrito por Said, teria uma potência duradoura maior do que qualquer das epistemes descritas poelo pensador francês - uma vez que este descreveria, em $A$ Palavra e as Coisas, a sucessão dessas ao longo do período moderno, enquanto Said parece abarcar na mesma estrutura discursiva, ao longo de Orientalismo, textos clássicos escritos na Antigüidade ou no início do Renascimento - como A Divina Comédia, de Dante - e textos jornalísticos ou discursos políticos correntes, sem maior especificação das diferenças desses textos em relação à sua estrutura interna e às suas relações com a política de seus tempos. Alguns críticos apontaram a dificuldade em definir temporalmente o período de vigência do discurso orientalista como um obstáculo ao argumento de Said. Aijaz Ahmed, por exemplo, aponta que Said oscilaria entre uma delimitação moderna desse discurso (via influência de Foucault) e de sua associação com uma "textualidade européia contínua", cujas origens estariam na Grécia antiga - esta segunda opção sendo uma influência direta, segundo Ahmad, do "alto humanismo" de autores como Erich Auerbach, cuja obra teria marcado profundamente a formação de Foucault (ver Ahmad, 2002: 110-116). 
"orientalismo", que, em muitos momentos, não deixa margem para a diferença em seu interior; essa categoria, em outros termos, traz dificuldades para a análise de obras individuais e contextos específicos, assim como impõe barreiras a uma consideração das disputas constantes (políticas e intelectuais) a respeito das possibilidades de representação do não-ocidental. Em síntese, o maior risco das investidas de Said é a descrição do orientalismo como um mal congênito do Ocidente: o orientalismo pode ser lido como uma espécie de ontologização da incompreensão ocidental sobre o oriental.

Quanto ao problema dos contextos diversos, uma crítica comum que vem sendo desenvolvida por autores latino-americanos é que esse primeiro esquema saidiano deixaria de fora experiências de sociedades que se constituíram no entrechoque com o colonizador português ou espanhol em um período de "primeira modernidade" (ver, por exemplo, Dussel, 2000; Mignolo, 2000 e 2003; e Quijano, 2000). Essa consideração é de extrema importância para este trabalho: o discurso europeu não "nasce" e encontra sua forma definitiva como um "orientalismo" - não há critérios históricos para se afirmar que o processo de dominação européia sobre populações não-européias teria sua realização máxima no período posterior ao lluminismo e à Revolução Industrial, como parece sugerir o recorte de Said. Tratase de um processo anterior, distinto em suas múltiplas realizações e que gerou uma diversidade de formas discursivas eurocêntricas atreladas a processos materiais de dominação.

Esses tipos de crítica a Orientalismo, de formas e em tons diversos, irá marcar tanto os trabalhos que buscam se afastar ao máximo da obra de Said (como, por exemplo, Irwin, 2008; Lewis, 1993), quanto aqueles que, de alguma forma, compartilham de preocupações intelectuais e políticas com o autor (Ahmad, 2002; Dirlik, 2003; Moore-Gilbert, 1997; Quijano, 2000). O próprio Said, nas duas décadas seguintes à publicação de seu clássico, passou a absorver grande parte dessas críticas, porém sem abandonar a coerência de um projeto intelectual "militante" e anti-eurocêntrico. Sobretudo no livro Cultura e Imperialismo, Said busca uma caracterização das formas de entrelaçamento entre cultura metropolitana e imperialismo que se afasta de forma significativa daquele estruturalismo dramático de Orientalismo. Nesse processo, a sombra de Foucault, apesar de nunca desaparecer, vai perdendo espaço para outras referências teóricas - sobretudo 
para Gramsci e pensadores "descoloniais" e periféricos, como C.L.R. James e Fanon.

Nesse novo enquadramento que se vai constituindo entre o início da década de 1980 e meados da década de 1990, menos totalizante e mais flexível que o inicial, Said mostra grande desconforto com a ausência de uma perspectiva de mudança e de uma possibilidade de agência no esquema foucaultiano de análise de discurso. Tendo isso em mente, como já apontado, Said passa a dar maior centralidade às manifestações de resistência à dominação ocidental material e discursiva. Nessa nova forma de abordar o mesmo problema, Said tenta escapar da prisão estruturalista que ele havia erigido em seu livro clássico. Como aponta Ahmad, em Orientalismo, Said buscaria mostrar o nó secular que se teria firmado entre o "Alto Humanismo" ocidental e o colonialismo; contudo, ao buscar brevemente refletir sobre as formas de agência que poderiam desatar esse nó, Said lança mão de valores e conceitos do próprio "liberalismo humanista", sem uma invocação de atores e processos históricos reais que disputariam projetos de sociedade (e projetos discursivos relacionados àqueles) de conteúdo antieurocêntrico. Nas palavras de Ahmad, "o que é notável a respeito dessa afirmação às vezes retumbante do valor humanista é que o humanismo-como-idealidade é invocado precisamente no momento em que o humanismo-como-história foi rejeitado tão inequivocamente" (Ahmad, 2002: 114). O que sustentava a crítica, naquele primeiro esquema saidiano, era um conjunto de valores depurados do humanismo ocidental, sem uma ligação a processos sociais específicos; ou, como ele parece expressar em diversos momentos (ver, por exemplo, Said, 2003: 25-26), sua própria experiência como um "homem do exílio" - um palestino que recebeu uma educação ocidental e que, em todos os momentos de sua biografia, teria experimentado a sensação da inadequação, do deslocamento e da exterioridade que garantiria outro ponto privilegiado de crítica à tradição ocidental eurocêntrica. Pode-se perceber que, em Orientalismo, há uma tensão interna ao projeto de crítica ao eurocentrismo - tensão que só se resolve com um movimento para além da confiança irrestrita ou exclusiva de Said no humanismo, ou, ainda, de sua crença na possibilidade de autocertificação da crítica.

Em Cultura e Imperialismo, o autor busca outras estratégias para identificar atores e discursos anti-eurocêntricos. Sobretudo, ele busca realizar um exercício de "leitura em contraponto" (Said, 1995: 104), um método de crítica cultural que busca 
desvelar a "estrutura de sentimentos" em que se encontram mergulhadas as culturas centrais - estrutura que faria parte da aventura imperial européia -, mas também as culturas periféricas ou coloniais. Sem o imperativo de constituir uma estrutura bem definida de possibilidades do próprio saber, trata-se, nesse segundo momento da obra de Said, da elaboração de uma forma de leitura cultural voltada a estabelecer as relações entre imperialismo e cultura: "Ler Austen sem ler Fanon e Cabral - e assim por diante - é separar a cultura moderna de suas ligações e comprometimentos" (Said, 1995: 97).

Essa nova forma de compor seu exercício crítico é, em termos que poderíamos emprestar de Walter Benjamin, uma demonstração das articulações entre cultura e barbárie própria aos "monumentos" culturais ocidentais. Como se pode perceber, o foco de Said é deslocado de uma análise dos discursos ocidentais como fenômenos logicamente discretos (que se definem pela inferiorização do outro) para uma consideração das relações entre fenômenos políticos e produções culturais no centro e na periferia colonial, articulados pela lógica assimétrica do imperialismo.

Esse desenvolvimento ulterior da crítica saidiana abre caminhos para uma leitura mais flexível e, de certo, mais proveitosa dos problemas tratados em Orientalismo. Distanciado de uma ânsia estruturalista, Said continua a fornecer importantes considerações sobre as temáticas e categorias que permearam as formas ocidentais de fazer sentido sobre as sociedades orientais. Para isso, sai de cena o "orientalismo" e passa-se a trabalhar a partir de uma idéia de "estruturas de atitudes e referências" (baseada no trabalho do crítico marxista Raymond Williams) nas formas de intercâmbio cultural entre Ocidente e Oriente; uma estrutura apropriada de formas diversas por atores em contextos específicos. Nos termos de Said:

“...quero mostrar que a 'estrutura de atitudes e referências' prevalece e exerce influência de todas as maneiras, em todas as formas e lugares, mesmo bem antes da chamada era do império; longe de ser autônoma ou transcendente, ela está próxima do mundo histórico; longe de ser fixa e pura, ela é híbrida, partilhando da superioridade racial bem como da genialidade artística, da autoridade política bem como da 
técnica, de procedimentos simplistas e redutores bem como de métodos complexos" (Said, 1995: 155-6).

Dessa maneira, Said tenta mostrar que o Imperialismo (assim como, posteriormente, formas violentas e assimétricas de capitalismo global) estaria articulado a um horizonte de conceitos, problemas e imagens que povoariam 0 imaginário ocidental e colonial. A literatura, dessa forma, não pode ser vista como uma consideração das relações entre grandes obras que, no Ocidente, constituiriam um cânone, mas como um local de interseção de uma estrutura de atitudes e referências marcadas por aquela lógica assimétrica de poder global. Dessa maneira, Said passa a trabalhar não apenas com obras clássicas ocidentais que teriam realizado apropriações específicas daquela estrutura - como Heart of Darkness, de Conrad, ou Aida, de Verdi -, mas igualmente com o seu contraponto colonial: entram em cena os textos de Fanon e C. L. R. James ou as múltiplas apropriações por autores "descoloniais" caribenhos de A Tempestade, de Shakespeare. Uma leitura em contraponto, em síntese, leva em conta tanto o processo de imperialismo como a resistência a ele, o que exige uma expansão do horizonte de leitura dos chamados "clássicos" da literatura européia, incluindo o que se mostra escondido - ou seja, o próprio imperialismo e as reações político-culturais a ele.

Essa nova forma de avançar uma crítica ao pensamento eurocêntrico aproxima o trabalho de Said daquele de diversos outros pensadores sociais, políticos e teóricos pós-coloniais contemporâneos que vêm se debruçando sobre a construção de discursos teóricos e políticos sobre as sociedades não ocidentais produzidos nestas, seja em um contexto imperial ou de grande assimetria de poder. Nesse sentido, sem que se lance mão de uma espécie de enteléquia teórica de validade universal, pode-se pensar nas formas pelas quais uma "consciência européia da modernidade" foi se constituindo ao longo dos últimos séculos e, simultaneamente, produzindo uma imagem do não-idêntico (o não europeu, o colonial, o oriental...) que se manteve atrelada a uma imagem de si, funcionando como seu princípio de legitimidade e garantia de superioridade. Podemos pensar nessa "imagem" - para utilizarmos um termo pouco preciso, de início - como uma estrutura de atitudes e referências eurocêntricas, atrelada à constituição material de um sistema mundial moderno de cujo centro emanam essas formas de pensar e de 
orientar a ação política. Dessa forma, as relações políticas e simbólicas entre Ocidente e Oriente têm sua especificidade definida em termos de uma estrutura política e econômica própria à modernidade capitalista, cujo centro foi-se constituindo no Ocidente (e, ao mesmo tempo, foi constituindo o próprio Ocidente).

Portanto, essa forma de crítica pós-colonial passa a fazer sentido no interior de uma consideração do capitalismo moderno. Como aponta Said:

\begin{abstract}
"Todas as culturas tendem a elaborar representações culturais estrangeiras a fim de melhor dominá-las ou de alguma forma controlá-las. Mas nem todas as culturas fazem representações de culturas estrangeiras e de fato as dominam ou controlam. Este é o traço distintivo das culturas ocidentais modernas. Isto exige que o estudo do conhecimento ou das representações ocidentais do mundo não europeu seja um exame tanto dessas representações quanto do poder político que elas expressam" (Said, 1995: 143).
\end{abstract}

O eurocentrismo pode ser descrito, dessa maneira, como o imaginário dominante do sistema mundo moderno (Mignolo, 2003: 49; Wallerstein, 2007). Tendo isso em vista, pode-se pensar o eurocentrismo como um conjunto de categorias e imagens de mundo adaptável às alterações na organização do poder global, mas sempre emitido a partir de um ponto de vista do centro europeu/ocidental desse sistema. Esse olhar central hegemônico ontologiza as diferenças com relação às outras sociedades (periféricas), enxergando-as como formas incompletas de realização de um ideal moderno ${ }^{7}$.

\footnotetext{
${ }^{7}$ A definição do "sistema mundo moderno" como horizonte para análise da constituição e operação do eurocentrismo vem sendo avançada por autores latino-americanos a que já me referi acima. Essa consideração permite uma análise das formas como esse discurso surgiu nos contatos com povos e regiões não-européias em um período anterior à "Era do Imperialismo", assim como as formas como ele foi apropriado para a compreensão dos dilemas da modernidade dessas sociedades - sobretudo na América Latina. Como aponta Mignolo, esse novo recorte ajuda a solucionar um "problema das temporalidades" na crítica pós-colonial: o sistema mundo moderno teria no século XVI seu momento de constituição, ao ponto que Said, Guha, o pós-estruturalismo e a teoria crítica alemã teriam no século XVIII e no lluminismo a fronteira cronológica da modernidade (Mignolo, 2003: 43). Como aponta Quijano (2000: 202), "América se constituyó como el primer espacio/tiempo de un nuevo patrón de poder de vocación mundial y, de ese modo y por eso, como la primera identidad de la modernidad".
} 
Como observa Boaventura de Sousa Santos, o raciocínio eurocêntrico moderno, absorvido em parte considerável pelas teorias sociológicas da modernidade, opera a partir de uma concepção de tempo em que o contemporâneo é apenas uma parte extremamente reduzida do simultâneo, a partir de uma operação reflexiva que estabelece um centro que, por sua vez, definiria a contemporaneidade. Como aponta este autor, baseando-se em Koselleck, essa "não contemporaneidade do contemporâneo" não problematiza a hierarquia envolvida na definição do contemporâneo (Santos, 2006: 100). Essa dicotomia entre contemporâneo/não-contemporâneo exemplifica a própria estrutura em que se organiza a maioria dos discursos eurocêntricos. O dualismo, em formas diversas, é um dispositivo lógico essencial ao discurso eurocêntrico ${ }^{8}$.

Norberto Bobbio aponta que essa espécie de "ideologia européia" constituise ao longo da história, no entrechoque com as populações "não-européias" (esta idéia sendo, igualmente, histórica). Na época moderna, quando esses entrechoques tornaram-se mais freqüentes, a "ideologia européia" - que reúne "... em uma rápida síntese, os traços de um modo geral de conceber a política no qual se refletiu orgulhosamente durante séculos a consciência da Europa" (Bobbio, 1996: 143) - alimentou-se de formulações e imagens bipolares que remetiam ao pensamento grego e às primeiras conceituações da idéia de um "despotismo oriental" (Bobbio, 1996).

Conforme se observou anteriormente, as várias formas daquela estrutura de atitudes e referências eurocêntricas não são dominantes apenas nos primeiros trabalhos da Idade Moderna que trataram de caracterizar as sociedades não-

${ }^{8}$ Como afirma Quijano: "Esa perspectiva binaria, dualista, de conocimiento, peculiar del eurocentrismo, se impuso como mundialmente hegemónica en el mismo cauce de la expansión del dominio colonial de Europa sobre el mundo. No sería posible explicar de otro modo, satisfactoriamente en todo caso, la elaboración del eurocentrismo como perspectiva hegemónica de conocimiento, de la versión eurocéntrica de la modernidad y sus dos principales mitos fundantes: uno, la idea-imagen de la historia de la civilización humana como una trayectoria que parte de un estado de naturaleza y culmina en Europa. Y dos, otorgar sentido a las diferencias entre Europa y no-Europa como diferencias de naturaleza (racial) y no de historia del poder. Ambos mitos pueden ser reconocidos, inequívocamente, en el fundamento del evolucionismo y del dualismo, dos de los elementos nucleares del eurocentrismo" (Quijano, 2000: 211). Apesar de considerar adequada a caracterização de Quijano sobre o dualismo e o evolucionismo como formas lógicas de organização da maior parte dos discursos eurocêntricos, é importante destacar que nem sempre ele se expressa na forma de discursos racistas, sobretudo quando nos referimos a trabalhos elaborados ao longo do século XX. Nesse sentido, como veremos logo à frente, creio ser mais adequado pensar o "essencialismo" como uma descrição geral da forma como nos discursos eurocêntricos outorga-se sentido às diferenças entre Europa e não Europa. 
ocidentais. A sociologia, como ciência, origina-se em um ambiente cultural embebido pelo caldo de cultura eurocêntrico, durante um período de aprofundamento da dominação colonial européia em regiões periféricas. Desde o início, mesmo a proposição de suas questões fundamentais orientou-se pelo quadro categorial do eurocentrismo - ou seja, este forneceu uma estrutura de atitudes e referências que orientou, em grande medida, a elaboração de suas categorias e teorias fundamentais. Dessa forma, os fundamentos da sociologia moderna foram estabelecidos a partir de estruturas e valores presentes em sociedades ocidentais, a partir das quais se estabeleceriam parâmetros de comparação para o que seriam "sociedades modernas" (Costa, 2006: 119; Hall, 1992: 314). É nesse sentido que uma parcela hegemônica das teorias sociológicas da modernidade (e do "nãomoderno") forneceram uma versão científica a formas do discurso eurocêntrico em circulação, auxiliando na longevidade daquele imaginário europeu moderno.

De forma simplificada, nas diversas formas de discurso sociológico eurocêntrico, o "Ocidente" assume a função de uma cultura padrão, detentora de uma série de características essenciais em termos das quais as outras sociedades podem ser tratadas como deficientes. Dessa maneira, como mostra Turner, uma tabela de atributos positivos e negativos pode ser estabelecida, a partir da qual se podem avaliar os processos históricos de outras sociedades (Turner, 1994: 37). A modernização, no discurso eurocêntrico que, em grande medida, informa as teorias sociais clássicas, pode ser confundida com a consumação natural do desdobramento de etapas evolutivas, em sociedades dotadas de um certo número de variáveis sociais - e não como um processo contingente, situado no tempo e no espaço e derivado das disputas sociais específicas. A ausência de uma dessas variáveis constitui, dessa maneira, um obstáculo ao desenvolvimento dessas sociedades. Esse discurso sociológico funda-se em uma duplicação da narrativa ou seja, baseia-se em um raciocínio binário de fundo -, seja ela implícita ou explícita, a partir da qual se compõe o quadro da "normalidade" ou "completude" tidas como padrão de evolução social, base para a caracterização da "anormalidade" ou "incompletude" das sociedades dotadas de entraves àquele tipo de desenvolvimento.

Como observa Turner com relação à sociologia orientalista do Islã (mas que certamente se poderia estender para o discurso sociológico eurocêntrico, em geral), esta teria se fundado em uma epistemologia particular, predominantemente idealista 
e essencialista, segundo a qual o fracasso dessas sociedades em se desenvolverem ao longo de trajetos históricos ocidentais até uma sociedade racional, democrática e industrial se explica tendo-se por referência uma "essência dessas próprias sociedades" (Turner, 1989: 88). Trata-se, em resumo, de uma perspectiva sociológica internalista, de cunho essencialista. Nesse discurso, o "Oriente" (ou o não-Ocidente) pode ser definido como um "sistema de ausências", as quais constituiriam, em maior ou menor medida, "obstáculos" ao acesso dessas à modernidade (Turner, 1994: 39). Dessa forma, é possível perceber que grande parte das teorias sociológicas clássicas acabaram por fornecer dinâmica a uma forma de compreensão do real centrada naquela cisão fundamental entre "modernoocidental" e "atraso-não ocidental"; entre sociedades dinâmicas e estáticas; impessoais e personalistas; racionais e irracionais - no limite, funcionando como uma atualização, em um contexto moderno, da cisão grega entre civilização/liberdade e barbárie/despotismo (ver Bobbio, 1996).

Grande parte do pensamento atual que trata de sociedades periféricas e que, de alguma forma, realiza algum tipo de apropriação do eurocentrismo - seja ele produzido nas academias centrais ou periféricas -, sofreu uma influência das estruturas de referências eurocêntricas principalmente por meio do pensamento sociológico moderno. Referimo-nos, sobretudo, às sociologias de Marx e Weber ${ }^{9}$. Os dois autores, centrados em questões sobre o desenvolvimento do capitalismo e a racionalização processados no Ocidente, utilizam, de formas distintas (e variáveis, ao longo de suas obras), uma série de categorias e abordagens originadas em uma distinção fundamental entre Ocidente e não-Ocidente. Apesar da complexidade de suas obras, é inegável que em diversos momentos os autores lançam mão de abordagens internalistas e fornecem contribuições para a reafirmação dos elementos marcantes dos discursos eurocêntricos (Hall, 1992; Said, 2003; Turner, 1989 e 1994). Dentro de nossas preocupações, é preciso apontar as formas pelas quais importantes aspectos do pensamento desses autores se inserem e ajudaram a constituir uma tradição eurocêntrica de reflexão sobre a modernidade e as sociedades não-ocidentais.

${ }^{9} \mathrm{O}$ propósito aqui não é, evidentemente, denunciar o uso desses clássicos para a reflexão sobre essas sociedades periféricas, o que seria uma proposta completamente descabida. Contudo, é igualmente incorreto não nos atermos a como grande parte do pensamento social contemporâneo que busca fazer sentido dessas sociedades reproduz aspectos problemáticos da obra desses autores, em especial suas abordagens sobre as sociedades não-ocidentais. 
Nessa tradição, a idéia de obstáculo adquire uma importância central. Em Marx, essa idéia é sintetizada no conceito de "Modo Asiático de Produção", sendo este, como mostra Anderson, uma variação do conceito orientalista clássico de "Despotismo Oriental" (Anderson, 1985: 461-494). Em Weber, como se apreende a partir da análise de Schluchter (1996: 120), a idéia de obstáculo encontra-se principalmente nos pontos que balizam sua análise comparativa sobre as diferentes éticas econômicas: tipo de estado, leis, ciência e conduta de vida, podendo cada um desses elementos prover resistências ou não à ascensão do capitalismo racional - caso sirvam ou não à reafirmação da estereotipação, esta inibidora do "fluxo racional da vida cotidiana" (Pierucci, 2003: 131). Além disso, em ambos os clássicos há uma dicotomia de fundo entre o caráter dinâmico das sociedades ocidentais, em contraposição ao caráter estático das sociedades orientais (Turner, 1989: capítulo 1).

De forma esquemática, Turner busca descrever os principais componentes do discurso "orientalista" (Turner, 1994: 96-99). Creio que, a partir de nossas considerações acima, é possível nos orientarmos por esse raciocínio de Turner e tentar expandi-lo, buscando descrever os principais elementos do quadro categorial de uma sociologia eurocêntrica.

Primeiramente, o eurocentrismo pode ser visto como uma teoria do poder despótico. O segundo componente é a incorporação nesse discurso de uma teoria sobre a transformação social (ou, na verdade, de uma teoria sobre a ausência de transformação). Em terceiro lugar, o discurso orientalista apresenta uma teoria da sexualidade oriental ou não-ocidental em contraponto a um pretenso ascetismo ocidental. Por último, esse discurso incorpora uma teoria da disciplina e da racionalidade, pretensos traços ocidentais ausentes em sociedades não-ocidentais. A esses elementos, deve-se adicionar um quinto: o internalismo essencialista - a idéia de que há uma "essência cultural" que determina o desenrolar da história de uma certa coletividade humana, hipótese que afastaria a necessidade de se avaliar (ou de se dar centralidade analítica) às disputas internas entre grupos e indivíduos pertencentes a essas coletividades ou às relações entre estes e membros de outras coletividades. Relembro, por fim, que, em termos de estrutura lógica do discurso, o eurocentrismo pode lançar mão do dualismo e de alguma forma de evolucionismo 
histórico ${ }^{10}$. A articulação entre dualismo e evolucionismo é a forma lógica de organização de discursos históricos que - lançando mão de análises sobre estruturas de poder, racionalidades e formas de vida ou de padrões de organização social que perduram no tempo em sociedades tipicamente não entendidas como ocidentais - se organizam em torno de uma dicotomia básica entre completude (a experiência social moderna/ocidental tida como típica) e incompletude (sociedades "atrasadas", que poderão "chegar lá"), em formas de narrativa em que a História pode ser descrita como uma espécie de "sala de espera" (Chakrabarty, 2000: 8).

Entre esses elementos, o primeiro (teoria do poder), o segundo (teoria da transformação social), o quarto (disciplina e racionalidade) e o quinto (internalismo essencialista) receberão, neste trabalho, uma especial atenção: eles nos servirão de baliza para a tentativa de esquematização de um "setor" da estrutura de atitudes e referências eurocêntricas que organiza a descrição da dinâmica histórica de desenvolvimento das sociedades não ocidentais - um setor sociológico daquela estrutura mais ampla, por assim dizer.

O que busco no restante deste capítulo não é, evidentemente, desenvolver uma descrição exaustiva sobre as origens e desdobramentos do pensamento eurocêntrico entre os pensadores ocidentais. Pretendo apenas reconstruir as principais trilhas dessa forma de pensar sobre o Ocidente, os seus outros e a relação entre ambos, a partir de uma consideração de alguns momentos, textos e categorias chave do pensamento europeu - ou, em outros termos, busco reconstruir brevemente a constituição dos principais elementos daquela estrutura de atitudes e referências característica de um "setor sociológico" do pensamento eurocêntrico.

\section{Uma teoria do poder: a tradição do "Despotismo Oriental"}

O uso da idéia de "despotismo" como categoria chave na descrição das sociedades não européias é anterior ao desenvolvimento de uma dicotomia Ocidente/Oriente. Conforme essa dicotomia foi se constituindo como um dos

${ }^{10}$ É preciso advertir, porém, que os autores que trabalham a partir de uma perspectiva eurocêntrica ou que são de alguma forma influenciados por ela não se utilizam de todos esses elementos, necessariamente. Em geral, esses cinco elementos são utilizados seletivamente, conforme a sociedade analisada, a postura intelectual ou política do autor, ou a questão a que se quer dar destaque. 
elementos fundantes da consciência européia da modernidade, a idéia de despotismo passou a ser adjetivada como "oriental" - mesmo que o conceito fosse aplicado para a compreensão de sociedades não localizadas no Oriente, como as civilizações da América pré-colombiana. A idéia de "despotismo oriental" é o principal elemento da "teoria do poder despótico" que, como vimos, constitui um dos componentes de uma sociologia eurocêntrica.

Conforme afirma Bobbio (1996: 142-3), a história desse conceito atravessa o pensamento político europeu, funcionando como categoria fundamental para uma contraposição básica entre "governo das leis" (ou "governo da liberdade") e "governo dos homens" (ou "despotismo"). Em uma diversidade de pensadores europeus - de Platão e Péricles até os mais recentes teóricos políticos -, a primeira dessas formas foi entendida como a única capaz de garantir igualdade formal entre os indivíduos. Essa dicotomia, para além de uma formalização de princípios normativos antagônicos, passou a acompanhar a elaboração de uma "ideologia européia" fundada em uma cartografia dual: o governo dos homens, de início, seria uma representação conceitual da visão grega sobre os persas. Dessa forma, já no pensamento grego se operaria uma indexação entre, de um lado, princípios de organização de poder e, de outro, civilizações ou regiões.

A dicotomia liberdade/despotismo, central no pensamento político e social europeu, funcionou como o principal critério de distinção entre Ocidente e nãoOcidente (e, sobretudo, Oriente). O despotismo, como conceito síntese, foi sendo constituindo como verdadeira antítese de uma autovisão hegemônica da Europa uma espécie de denominador genérico para tudo o que o "outro" representava, a partir do qual o "Eu" europeu se firmava.

Nesse sentido, a contraposição entre "liberdade" ou "democracia" (nos tempos modernos) e "despotismo" não se refere apenas a uma categorização de diferentes formas de governo. Como aponta Bobbio,

“...a contraposição entre democracia e despotismo é parte constitutiva, vital, essencial daquela visão de mundo, daquela filosofia da história por meio da qual o pensamento europeu buscou, em antítese ao que é diverso e negativo, definir positivamente a própria identidade, em uma tradição ininterrupta embora com alternadas vicissitudes 
caracterizadas pela maior ou menor intensidade da contraposição" (Bobbio, 1996: 145).

A comparação entre estruturas sociais e estatais européias e asiáticas ganha força a partir dos trabalhos de Maquiavel e Bodin, produzidos em um contexto de aproximação e ameaça à Europa pelo Império Turco Otomano. A partir do século XVIII, o termo é estendido para além da Turquia, passando a constituir a categoria fundamental para se pensar a estrutura oriental de organização do poder (Anderson, 1985: 461-462). O grande responsável pela categorização iluminista da idéia e pela sua consagração no pensamento moderno é Montesquieu. Este autor, por seu tratamento sistemático do despotismo em O Espírito das Leis, confirma a continuidade de uma tradição européia, mas, igualmente, demonstra a posição que o Oriente assumia no imaginário da Europa da época do lluminismo, uma vez que seu pensamento se encontra exatamente no momento de passagem da filosofia clássica à sociologia moderna (ver Aron, 2008 e lanni, 1989).

A teoria das formas de governo de Montesquieu não comporta apenas um componente institucional (na tradição dos filósofos clássicos europeus), mas também uma ampla consideração "sociológica" (mesmo antes que a disciplina da Sociologia seja reivindicada, como aponta Aron, 2008) sobre as formas de vida e os princípios de legitimação do poder. Nesta, o despotismo é descrito como uma das três formas típicas, sendo as outras duas a República (que comportaria tanto a Democracia quanto a Aristocracia) e, entre essas, a Monarquia. Como se sabe, a cada uma dessas formas de governo corresponderia um determinado princípio: enquanto o princípio da República seria a virtude e o da Monarquia a honra, Montesquieu entende que o medo seria o princípio do Despotismo, na medida em que, em sociedades despóticas, o "homem é a criatura que obedece a outra criatura que manda" (Montesquieu, 1982: 63).

Ao longo de toda sua caracterização daquela forma de governo, o filósofo descreve o súdito do despotismo como uma espécie de escravo, para o qual o mando é algo naturalizado e a objeção a ele não se coloca como possibilidade: a obediência cega ao déspota exigiria ignorância, algo que se inscreveria na educação e na religiosidade dos povos sujeitos a essa forma de poder total (ver, p. ex., Montesquieu, 1982: 70). Em contrapartida, a elite governante despótica se formaria por uma transmissão direta do poder desde aquele que o deteria de forma 
suprema: "o vizir é o próprio déspota, e cada oficial particular é o vizir", uma vez que “...nesse governo, a autoridade não pode ser posta em dúvida; a do magistrado mais subalterno não o é mais do que a do déspota" (Montesquieu, 1982: 98).

Assim, o governo despótico se sustenta por meio de uma espécie de estamento onipotente no alto e pela submissão sem reação dos debaixo. $O$ despotismo, então, se basearia em uma "igualdade aniquiladora" de todos os súditos, uma vez que todos seriam iguais em sua sujeição aos mortais caprichos do déspota. Em um estado despótico, não haveria a figura política e jurídica da "pessoa" (Montesquieu, 1982: 108). Assim, Montesquieu, de forma exemplar, estabelece uma relação, fundamental para o pensamento eurocêntrico, entre uma teoria do poder e uma teoria das formas de vida ou de racionalidade - ou seja, das "causas morais" que sustentariam um regime, junto das causas naturais (clima e natureza do solo, entre outros; ver Aron, 2008: 33). O governo despótico dependeria não apenas de um aparato político de dominação, mas ele se assentaria em uma espécie de ser social servil, indisposto a rebelar-se ou a alterar o estado das coisas - como veremos com mais atenção à frente.

Em seu volumoso tratado, Montesquieu utiliza inúmeros exemplos para precisar seu conceito de despotismo, quase todos extraídos das histórias do Império Otomano, da China ou da Índia - sociedades da Ásia, região do mundo onde o despotismo se encontraria "naturalizado" (Montesquieu, 1982: 96). O filósofo fixa a idéia de que os Estados asiáticos não possuíam propriedade privada estável nem nobreza hereditária e, por conseguinte, eram de caráter arbitrário e tirânico.

Há, em todo o livro, aquela indexação clássica entre, de um lado, formas de vida e de governo e, de outro, uma região em que habita o "outro":

"Na Ásia, o poder deve ser sempre despótico, pois não sendo a servidão tão extremada, ocorreria logo uma divisão que a natureza da região não poderia suportar"; “...na Ásia reina um espírito de servidão que nunca a abandonou e, em todas as histórias desse continente, não é possível encontrar um só traço que marque uma alma livre; aí nunca se verá senão o heroísmo da servidão" (Montesquieu, 1982: 305). 
A obra de Montesquieu será de grande influência sobre a maneira como os grandes pensadores europeus dos séculos XVIII e XIX caracterizariam o Oriente entre eles, Hegel, James e John Stuart Mill, Richard Jones, Karl Marx e, já no século XX, Max Weber (Anderson, 1985; Bobbio, 1996; Turner, 1989). Como mostra Perry Anderson, os formuladores clássicos do conceito de despotismo oriental destacaram diferentes elementos para caracterizar aquela forma de governo, constituindo, entretanto, uma tradição intelectual dotada, em linhas gerais, de pressupostos comuns sobre os sistemas políticos e sociais asiáticos. Os traços distintivos desses sistemas seriam a posse estatal da terra, a ausência de restrições jurídicas, a substituição das leis pela religião, a ausência de nobreza hereditária, a igualdade social na servidão, a existência de comunidades aldeãs isoladas, 0 predomínio da agricultura sobre a indústria, a necessidade de obras públicas de engenharia hidráulica, o clima tórrido e, por fim, a imutabilidade histórica (Anderson, 1985: 471).

Montesquieu desempenha um papel fundamental para a consolidação, no imaginário europeu moderno, dessa imagem de Oriente despótico. Como aponta Aron (2008: 18), Montesquieu, dispondo de poucas informações concretas sobre as sociedades orientais, descreve-as como uma espécie de "deserto da servidão", em que o soberano reinaria absoluto, sustentado pelo medo; em que não haveria classes sociais em equilíbrio e nem o equivalente, em termos de valores, da virtude antiga ou da honra européia.

Em Marx, a idéia de "Despotismo Oriental" desdobra-se no conceito de "Modo Asiático de Produção". Valendo-se das mesmas fontes de Mill sobre a vida nas aldeias asiáticas e bastante influenciado pela caracterização de Hegel sobre a imutabilidade histórica das sociedades orientais, Marx tentou desenvolver, de forma oscilante ao longo de sua produção, um conceito que explicasse a diferença decisiva entre o desenvolvimento social ocidental e oriental ${ }^{11}$. É preciso apontar que

${ }^{11}$ Nimtz (2002) e Jani (2002) desenvolvem interessantes críticas ao tratamento de Marx
como um autor eurocêntrico, centrando-se, sobretudo, na dialética entre teoria e prática na
produção intelectual e na atuação política desse autor. Contudo, nenhum desses autores
debruça-se sobre a construção do conceito de Modo Asiático de Produção na obra de Marx.
De qualquer forma, algumas de suas observações e citações de Marx nos auxiliam a
desenvolver leituras de sua obra que não sejam esquemáticas e etapistas. Na seguinte
afirmação de Marx, em uma carta a um grupo de revolucionários russos, de 1877 , adverte
contra a transformação de seu "historical sketch of the genesis of capitalism in Western
Europe into a historical-philosophical theory of general development, imposed by fate on all
peoples, whatever the historical circumstances in which they are placed" (Marx, citado em 
Marx nunca se considerou um estudioso das sociedades não-européias, de maneira que o estudo dessas só adquire sentido em sua obra no interior de suas preocupações sobre o desenvolvimento do capitalismo na Europa. De qualquer forma, conforme o pensamento marxista adquiriu importância teórica e, sobretudo, política ao redor do mundo, suas considerações sobre a "sociedade asiática" ou sobre o "Modo de Produção Asiático" ganharam, igualmente, grande significação conceitual e política (ver Turner, 1993; Demant, 2007).

Esse conceito possui um estatuto bastante controverso no interior do marxismo: conforme aponta Turner, o conceito de Modo de Produção Asiático pode servir à formulação de um marxismo menos dado a esquemas teleológicos de evolução - evitando uma descrição marxista ortodoxa da história como uma sucessão de escravismo, feudalismo, capitalismo e socialismo. Contudo, a aceitação do conceito pode levar a que os marxistas endossem uma posição privilegiada da história ocidental em relação à oriental, uma vez que ele acentuaria um caráter progressista e dinâmico ocidental, em contraposição a um Oriente estacionário (Turner, 1993: 348). Nos termos já apresentados, parece tratar-se de um dilema entre duas versões diferentes de eurocentrismo: aceitando-o, lança-se mão de uma visão dualista da história; dispensando-o para se vincular às formas "vulgares" ou ortodoxas do marxismo (representadas, sobretudo, pela cartilha soviética), adere-se a uma história evolucionista.

O núcleo desse conceito é a idéia de que, devido ao "fato" de os Estados asiáticos serem os detentores de todas as terras, não se teria desenvolvido nessas sociedades uma estrutura de classes:

"O déspota aparece, aqui, como o pai das numerosas comunidades menores, realizando, assim, a unidade comum a todas elas... O despotismo oriental aparentemente leva a uma ausência legal de propriedade. Mas, de fato, seu fundamento é a propriedade tribal ou comum criada, na

Nimtz, 2002: 75). José Aricó, marxista argentino, aponta que o pensamento de Marx sofre uma espécie de "virada anti-eurocêntrica" na fase final de sua vida, a partir do estudo de sociedades periféricas (em especial a Rússia), quando passa a incorporar a idéia de que "... o modo capitalista de produção está condicionado por modos de produção que não se encontram no mesmo estágio alcançado pelo desenvolvimento do primeiro" (Aricó, 1982: 58). A partir daí, Marx passaria a trabalhar com um conceito de capitalismo mundial cujos desdobramentos aproximam-se daquilo que Trotski teorizou, posteriormente, a partir da idéia de "desenvolvimento desigual e combinado". 
maioria dos casos, por uma combinação de manufatura e agricultura dentro da pequena comunidade que, assim, fazse completamente auto-suficiente, em si mesma contendo todas as condições de produção e de produção de excedentes" (Marx, 1975: 67-68).

As possíveis conseqüências de ausência legal de propriedade da terra (já que o déspota seria o "proprietário efetivo" dela) e do insulamento das comunidades em unidades auto-suficientes seriam, para Marx, ou a "vegetação" dessas comunidades lado a lado, ou o desenvolvimento de sistemas comuns de trabalho (sistemas de irrigação, meios de comunicação...) como obras coordenadas pela unidade superior, centralizada e centralizadora (Marx, 1975: 68).

Além disso, Marx aponta uma diferença fundamental entre a história do desenvolvimento das cidades no Ocidente e no Oriente. No feudalismo europeu, a existência de cidades politicamente independentes teria sido crucial para a ascensão de uma classe burguesa e do capitalismo industrial; no Oriente, as cidades manter-se-iam subordinadas à agricultura e ao Estado; elas surgiriam ao lado das aldeias nos pontos favoráveis ao comércio exterior ou onde o chefe de estado e seus funcionários trocariam suas receitas por trabalho (Marx, 1975: 68). Em síntese, esse tipo de arranjo social - cujos fundamentos seriam a propriedade estatal da terra, a auto-suficiência das aldeias e o caráter estatal ou comercial das cidades - levaria à impossibilidade da existência de conflitos de classes como os que se produziram no Ocidente - e, sem isso, se bloquearia o funcionamento da principal força histórica dinâmica. Não haveria, enfim, qualquer tipo importante de "conflito social progressista" - o capitalismo não se poderia gerar internamente, tendo de ser trazido "de fora" (Turner, 1989: 36-38).

Este aspecto do pensamento marxiano - certamente bastante marginal frente ao conjunto de sua obra, porém não menos problemático dadas suas implicações ideológicas - foi abandonado por diversos marxistas posteriores, apesar de nunca ter sido completamente deixado de lado. O conceito de "Modo Asiático de Produção" ocupou importante espaço na produção intelectual marxista até, ao menos, a década de $60^{12}$. Contudo, a partir da década de então, o conceito 12 A alta carga ideológica do conceito não foi o único motivo para que a maioria dos
pensadores marxistas se afastassem dele ao longo das últimas décadas. Além desse
motivo, o conceito mostrou-se demasiadamente vago para dar conta da diversidade social 
passa a sofrer severas críticas dentro do próprio marxismo, perdendo grande parte de seu fôlego final com a obra de Perry Anderson Linhagens do Estado Absolutista, publicada em 1974.

Em Weber, por sua vez, essa tradição impacta na formulação de sua sociologia da dominação, ainda que de forma matizada. Desde sua ótica da modernidade (e de sua forma de dominação característica), Weber constrói os outros tipos de autoridade que sirvam de baliza para a definição da própria dominação racional. A forma fundamental de dominação, no Oriente de Weber apesar de não se restringir apenas a este -, seria um tipo de patrimonialismo centralizado, em contraste à descentralização do feudalismo. Weber denomina de formação estatal-patrimonial a estrutura de dominação em que um príncipe organiza sua dominação não-doméstica com o emprego de coação física contra os dominados, "sobre territórios e pessoas extrapatrimoniais (os súditos políticos), da mesma forma que o exercício de seu poder doméstico" (Weber, 1999: 240). Nesse tipo de dominação, o direito individual do soberano sobrepõe-se a qualquer outra forma de poder.

Em sua preocupação constante em descrever os aparatos a partir dos quais as diferentes formas de dominação se mantêm, Weber procura descrever a criação de cargos patrimoniais voltados à administração dos domínios do "príncipe". Nesse processo, Weber observa uma tendência da geração de uma estereotipificação dos cargos e funções oficiais - a qual não interessaria ao senhor, uma vez que essa fixação pode trazer desafios ao seu domínio. O autor observa, contudo, que esse é um processo bastante comum na história: "a estereotipagem e apropriação monopolizadora dos poderes oficiais pelos detentores, como companheiros jurídicos, cria o tipo 'estamental' do patrimonialismo” (Weber, 1999: 253). Weber

das sociedades asiáticas (Anderson, 1985; Demant, 2007). Ademais, o conceito foi criticado por falhas internas, sobretudo por apresentar uma contradição fundamental: como aponta Turner, por exemplo, é difícil entender como aldeias auto-suficientes poderiam ser compatíveis com um Estado centralizador que deveria manter uma intervenção permanente na economia destas (Turner, 1993: 350). A avaliação desse autor, ele mesmo amplamente influenciado pelo marxismo, parece exemplificar bem a postura atual de rejeição majoritária ao conceito no interior do marxismo: "O MPA teve uma importância negativa no marxismo já que sua função teórica não foi a análise da sociedade asiática, mas a explicação da ascensão do capitalismo na Europa dentro de um quadro comparativo. Portanto, a sociedade asiática foi definida como uma série de hiatos - a burguesia inexistente, a inexistência das instituições burguesas - que explicavam o dinamismo da Europa. A 'sociedade asiática' foi, dessa forma, uma manifestação, no marxismo, de uma problemática orientalista cujas origens remontam à filosofia política grega, passando por Hegel, Montesquieu e Hobbes" (Turner, 1993: 351). 
adverte, contudo, que essa estereotipificação não corresponde à instalação de uma típica burocracia moderna:

\begin{abstract}
"Ao cargo patrimonial falta sobretudo a distinção burocrática entre a esfera 'privada' e a 'oficial'. Pois também a administração política é tratada como assunto puramente pessoal do senhor, e a propriedade e o exercício de seu poder político, como parte integrante de seu patrimônio pessoal, aproveitável em forma de tributos e emolumentos" (Weber, 1999: 253).
\end{abstract}

O centralismo desse estado patrimonial, a subordinação da sociedade a critérios estatais e a conseqüente debilidade política e econômica dos diferentes setores da sociedade seriam fatores que impossibilitariam o desenvolvimento de um sistema capitalista moderno, autônomo e suficiente (ver Kuper, 1989: 81).

Deve-se a Karl Wittfogel, em Oriental Despotism: a comparative study of total power (1957), o principal uso do conceito de despotismo oriental, no século XX. Wittfogel, bebendo sem restrições da tradição que erigiu durante séculos o conceito, entende sua empreitada teórica como uma tarefa crítica, em particular contra a vulgata etapista soviética. O autor descrevia o estado soviético como uma das variações contemporâneas daquela forma de organização total do poder que ele tentava descrever - uma forma na qual o estado seria o principal agente econômico e político, sem qualquer forma de equilíbrio que lhe limitasse o poder. No "despotismo oriental", como descrito por Wittfogel, a burocracia que dirige o estado assume um estatuto fundamental:

"Richard Jones and John Stuart Mill indicated that in Oriental society the officials enjoyed advantages of income which in the West accrued to the private owners of land and capital. Jones and Mill expressed a significant truth. But they did so only in passing and without stating clearly that under agrodespotic conditions the managerial bureaucracy was the ruling class... The present inquiry analyzes the patterns of class in a society whose leaders are the holders of despotic state power and not private owners and entrepreneurs" (Wittfogel, 1957: 4; destaques meus) 
Como se vê por esse trecho bastante significativo do livro, Wittfogel consegue realizar uma espécie de guinada weberiana nas análises de Marx sobre as sociedades orientais. O autor aponta que Marx, apesar de ter absorvido as principais lições da tradição européia de estudos sobre o Oriente, haveria fracassado em concluir que, sob o Modo de Produção Asiático, a burocracia constituía a classe dirigente (Wittfogel, 1957: 6) ${ }^{13}$. Contudo, aproximando-se de alguns dos momentos mais questionáveis da obra de Marx, Wittfogel igualmente aponta o suposto caráter estacionário da "Sociedade asiática" - sempre utilizando essa expressão no singular, vale observar - e o caráter progressista, ao menos na teoria, da ação imperialista européia sobre as sociedades asiáticas (ver, p. ex., Wittfogel, 1957: 8).

A partir dessas breves exposições, pode-se perceber que o núcleo da tradição do despotismo oriental é a idéia de que, naquelas sociedades, o Estado é tudo e a sociedade não é nada. A visão eurocêntrica sobre o poder despótico centra-se na noção de que a estrutura das sociedades não-ocidentais seria caracterizada pela ausência de sociedade civil, ou seja, pela inexistência de instituições mediadoras entre o indivíduo e o Estado. Isso criaria as condições para a exposição permanente do indivíduo ao livre arbítrio do Estado (ou do déspota), assim como explicaria o fracasso do desenvolvimento endógeno do capitalismo fora da Europa (Turner, 1994: 23; Schluchter, 1996: 175).

Entretanto, como já pontuamos acima, a teoria do poder despótico articulase, na maioria das vezes, a uma consideração sobre os fundamentos sociais para a sustentação desse poder. Ou seja, costuma haver uma articulação, no interior das várias formas de discurso eurocêntrico, entre uma explicação sobre o poder total e sobre as formas de vida ou padrões sociais de racionalidade que permitem que essas estruturas de poder se mantenham indefinidamente. Não se procura formular aqui uma teoria geral dos discursos eurocêntricos - e, como já se tentou mostrar

\footnotetext{
${ }^{13}$ Este trabalho de Wittfogel foi, de fato, visto como uma crítica feroz à ortodoxia comunista que, em 1931, na Conferência de Leningrado, havia rejeitado a relevância do conceito de "Modo de Produção Asiático" para a análise das sociedades orientais, uma vez que, em grande medida, ele se chocava com o etapismo oficial, como já apontado. O autor, por sua vez, argumentava que o abandono desse conceito pela cúpula do partido devia-se ao risco em se admitir a possibilidade teórica de uma classe dominante que controlasse os meios de administração sem possuir propriedade privada, uma vez que isso poderia indicar uma continuidade de poder político da Rússia czarista na Rússia stalinista (Turner, 1993: 350).
} 
nas páginas anteriores, essa teoria seria de pouco valor para a compreensão de realizações singulares dessa estrutura geral de referências eurocêntricas; contudo, a análise apresentada até o momento leva-me a crer que a dicotomia liberdadedespotismo apresenta uma grande afinidade com outras duas dicotomias conceituais básicas: racionalidade/irracionalidade e progresso/imobilidade.

\section{Racionalização e conduta de vida metódica}

Os discursos eurocêntricos sobre as sociedades não-ocidentais são permeados por diversas narrativas sobre a insuficiência das formas de vida, visões de mundo e princípios de orientação da conduta dos povos não-ocidentais, em contraponto às formas de vida e racionalidade descritas como ocidentais. Como se pode observar, não se trata de uma definição muito precisa sobre um setor da vivência social, mas de uma variedade de elementos culturais, religiosos e valorativos que orientariam a conduta geral dos indivíduos de uma determinada coletividade, condicionando ou restringindo a capacidade de agência de indivíduos e grupos sociais frente ao peso das estruturas tradicionais de dominação e organização social. Os diversos autores dessa tradição que tento descrever buscaram decantar os princípios gerais da "racionalidade" criativa e progressista ocidental a partir da contraposição à ausência desses condicionantes nas culturas não-ocidentais.

Voltemos brevemente a Montesquieu. Como se apontou anteriormente, a categoria "despotismo", na obra desse pensador, compreende não apenas as formas de organização do governo, mas as formas de vida e princípios de conduta que a elas corresponderiam. O autor desenvolve uma extensa tentativa de relacionar as "paixões" e caracteres do espírito dos diferentes povos com as suas formas de organização social e de governo. A "servidão dos povos da Ásia" descrita por Montesquieu se sustenta no caráter do espírito dessas sociedades, marcado por uma de "indolência" natural e pela ausência de "coragem" - uma espécie de torpor perene que lhes abafaria qualquer criatividade ou empreendedorismo: 
"Se, a esta fraqueza dos órgãos que faz com que os povos do Oriente recebam as mais fortes impressões do mundo, acrescentardes certa preguiça do espírito, relacionada naturalmente com a do corpo, que faz com que esse espírito não seja capaz de qualquer ação, de qualquer esforço, de qualquer contenção, compreendereis que a alma, que uma vez recebeu impressões, não mais pode modificar-se. É isso que faz com que as leis, os costumes e as maneiras, mesmo as que parecem indiferentes, como a maneira de vestir, sejam hoje, no Oriente, semelhantes às de mil anos atrás" (Montesquieu, 1982: 260).

Este trecho do raciocínio de Montesquieu é notável na forma como ele sintetiza a relação entre a ausência de uma racionalidade criadora e a manutenção de uma estrutura social ossificada. Ela é ilustrativa de um raciocínio que será característico, posteriormente, das Ciências Sociais no século XIX, em seu exercício de descrição de estáticas sociais (com foco analítico nas estruturas) e dinâmicas sociais (com foco nos agentes). O Oriente fornecia, na imaginação moderna européia, as imagens síntese da "estaticidade" - em uma amostra que mesmo as temáticas mais elementares das Ciências Sociais modernas são marcadas por uma lógica assimétrica de poder global.

Já em Montesquieu encontramos um outro importante aspecto da descrição eurocêntrica sobre a ausência de uma racionalidade criadora oriental, referente às formas religiosas e os incentivos à ação dela decorrentes - o que, em linguajar mais contemporâneo, poderíamos descrever como as diferentes "éticas religiosas". Montesquieu tenta elaborar, em diversos momentos de seu livro, comparações entre a religião cristã e a "maometana", mostrando como a primeira convém melhor a governos moderados, enquanto a segunda conviria a governos despóticos. A religião maometana, tendo sido imposta por um conquistador, agiria sobre os homens "com este espírito destruidor que a fundou" (Montesquieu, 1982: 474-476).

No pensamento social contemporâneo, nenhum outro pensador desenvolve uma teoria da racionalidade ocidental mais influente do que aquela de Max Weber. Essa temática atravessa toda a sua obra, não se restringindo apenas à Ética Protestante: mesmo seus estudos comparativos de sociologia da religião apontam para esse objetivo norteador de compreensão do processo de racionalização que teria se dado no Ocidente. Como observa Schluchter, um de seus maiores 
estudiosos contemporâneos, sua sociologia comparada correspondia, em última instância, a uma sociologia da burguesia, ou seja, um estudo das afinidades eletivas entre constelações de classe burguesas e modos de conduta de vida religiosamente condicionados, cujo modelo máximo de efetivação teria se dado com 0 Protestantismo ascético (Schluchter, 1996: 107).

A idéia geral desenvolvida por Weber, sobretudo n'A Ética Protestante, é a noção de afinidade eletiva entre essa ética (uma conduta de vida religiosamente condicionada) e o espírito do capitalismo. A teoria da racionalização como um processo de mudança cultural peculiar ao Ocidente foi a base para 0 desenvolvimento de toda a sociologia weberiana. Apenas no Ocidente ter-se-ia desenvolvido o tipo de racionalidade que possibilitaria, de forma mais efetiva, o rompimento com a tradição e o estabelecimento do autocontrole que, por sua vez, encontrariam máxima afinidade com o espírito do capitalismo. A ética protestante seria a realização máxima da forma peculiarmente ocidental de "racionalismo de dominação do mundo": essa ética sendo caracterizada por um ethos que apresentaria uma enorme afinidade com o "espírito do capitalismo moderno", desenvolvido no Ocidente $^{14}$. Ela seria a orientadora de uma racionalização das condutas de vida no mundo. Assim, essa ética religiosa, na forma como era apropriada pelos indivíduos, fornecia as modalidades de conduta de vida e de concepções sobre trabalho, lucro e ascetismo que se adequariam às transformações sociais e às exigências psicossociais próprias ao capitalismo em gestação no Ocidente, ou seja, apresentaria afinidades com o "espírito do capitalismo", cujo principal adversário era uma espécie de sensibilidade e de comportamento que Weber chama de tradicionalismo - um conjunto de obstáculos à instalação daquela nova forma de organização social e de orientação de condutas. Em outros termos, o desencantamento do mundo se realizaria, com nova ética religiosa puritana, com a mais larga das conseqüências.

Por esses caminhos, o problema da origem do capitalismo - que na tradição marxista é tratado em termos da "acumulação primitiva de capital" e dos problemas políticos e sociais próprios ao desaparecimento da ordem feudal - é tratado por

\footnotetext{
${ }^{14}$ Weber não deixa dúvidas quanto à restrição geográfica em sua descrição do capitalismo moderno: "Escusado dizer, dada a própria colocação do problema, que aqui se trata apenas do capitalismo da Europa Ocidental e da América do Norte. 'Capitalismo' existiu na China, na Índia, na Babilônia, na Antigüidade e na Idade Média. Mas, como veremos, faltava-Ihe precisamente esse ethos peculiar" (Weber, 2004: 45; destaque no original).
} 
Weber, de forma mais desenvolvida e sem desconsiderar os elementos materiais igualmente envolvidos, como o problema da ascensão desse novo espírito:

\begin{abstract}
"Para saber quais as forças motrizes da expansão do capitalismo moderno não se precisa pôr em primeiro lugar a questão da origem das reservas monetárias valorizáveis como capital, e sim antes de mais nada a questão do desenvolvimento do espírito capitalista. Por toda parte onde emerge e se efetiva, lê cria para si as provisões monetárias como meios de sua efetivação, não o contrário" (Weber, 2004: 61; destaque no original).
\end{abstract}

Com essa mudança de eixo, o raciocínio de Weber contempla de forma mais definitiva a caracterização de internalismo que marca a maioria dos discursos eurocêntricos, uma vez que as causas fundamentais da emergência do regime capitalista moderno são buscadas no interior de uma região ou civilização, sobretudo a partir de uma consideração de seus elementos culturais - em Weber, correspondentes à racionalização das formas de vida, a partir das "afinidades eletivas" entre uma certa ética religiosa e certas formas de ética profissional próprias ao capitalismo (ver Weber, 2004: 83).

Apesar de sua notável sofisticação, a teoria weberiana da racionalização assenta-se na dicotomia eurocêntrica entre "Ocidente racional e progressista" e "Oriente irracional e preso à tradição". Essa dicotomia aparece mais claramente em seu estudo sobre a China, em que ele desenvolve uma comparação entre a ética protestante e o confucionismo. Como aponta Steinmetz, sua análise comparativa das religiões mundiais pode ser vista como uma continuação teórica, apesar de matizada, do trabalho de Hegel, uma vez que pressupõe uma espécie de hierarquia entre elas - no limite, levando a cabo uma espécie de "racismo civilizacional ou cultural" (não biológico, por certo) que dava a coerência a seu empreendimento comparativo e à sua elaboração teórica (ver Steinmetz, 2006: 9).

A grande temática em torno da qual essa comparação se constrói é a idéia de "impessoalização". Essa temática também já aparece no texto d’A Ética, constituindo um dos traços fundamentais do processo de racionalização: a ruptura com a tradição exigiria o estabelecimento cada vez mais amplo de relações 
impessoais. A ética puritana execraria a "divinização da criatura"; a conduta de vida puritana canaliza as energias "para os trilhos da ação objetiva (impessoal)... Toda relação pessoal de caráter puramente sentimental - e portanto não condicionada racionalmente - de pessoa para pessoa incorre muito facilmente na suspeita, aos olhos tanto da ética puritana como de toda ética ascética, de cair em divinização da criatura" (Weber, 2004: 208; destaque no original).

É interessante perceber que a comparação de sistema sociais tendo-se por critério o nível de impessoalização das relações entre os indivíduos ocupa ainda um espaço importante na sociologia da dominação de Weber, em especial como forma de comparação entre o princípio burocrático e os pré-burocráticos de dominação. Entre estes, o patriarcalismo, baseado na "santidade da tradição", é descrito a partir dessa dicotomia: ele se assentaria, em sua essência, não no dever de "servir a uma 'finalidade' objetiva e impessoal e na obediência a normas abstratas, senão precisamente no contrário: em relações de piedade rigorosamente pessoais" (Weber, 1999: 234).

A interpretação que Weber faz da China é estruturada em torno da premissa da estagnação econômica e da incapacidade do desenvolvimento interno do capitalismo $^{15}$. Na China de Weber, persistiria o poder da magia - não há um processo de desencantamento - e da parentela, em contraposição ao Ocidente, onde se desenvolveria um racionalismo puramente objetivo inacessível aos povos orientais, voltado à dominação do mundo, mediante a descoberta de suas regularidades impessoais (Weber, 1987: 151) ${ }^{16}$. O confucionismo serve a uma reiteração tradicionalista dos laços com familiares ou assemelhados, "mas sempre com pessoas e não com tarefas objetivas" (Weber, 1987: 153). "Nenhum elo intermediário conduzia do confucionismo e de sua ética... para um modo de vida

${ }^{15}$ George Steinmetz aponta que Weber se baseou amplamente nos escritos de J. J. M. Groot, o sinologista alemão que defendia, em oposição à maioria de seus colegas acadêmicos, o caráter semi-civilizado da China, em vez de considerá-la uma civilização mundial. Seguindo aquele estudioso, Weber não haveria dado atenção ao crescimento do capitalismo chinês em fins do século XIX ou ao impacto de forças externas - como o imperialismo ocidental e a entrada forçada do ópio britânico - sobre a economia e "ética" chinesa (ver Steinmetz, 2006: 9).

${ }^{16}$ Há que se observar que essa impessoalização, apesar de ser peça fundamental de sua descrição do processo de racionalização ocidental, também é a peça chave para a compreensão da crítica de Weber à modernidade: a "dominação da impessoalidade" levaria a uma atitude instrumental em relação a si, aos outros e à natureza (Ver Souza, 1997: 67). A "jaula de ferro" da modernidade derivaria exatamente desse processo sistemático de impessoalização - ou de "reificação", como desenvolveria Lukács, bastante influenciado pela leitura de Weber. 
burguês. Mas é somente este que importava. E o puritanismo - inteiramente contra sua vontade - o criou" (Weber, 1987: 154). A ética confuciana seria, assim, uma ética fundada na magia e no personalismo, ambos fixadores de formas de vida tradicionais (ver Weber, 1999: 271). Obstáculos à modernização, portanto.

\section{Internalismo culturalista e "história imóvel"}

Como mostra Turner (1989: 9-10), a sociologia do século XIX considerava, em geral, que a análise dos fenômenos sociais compreendia tanto uma estática social - criação de tipologias de sistemas sociais em função de suas condições necessárias de existência e a interdependência entre suas partes - quanto uma dinâmica social - análise do desenvolvimento histórico de sistemas sociais a fim de se chegar a leis gerais de evolução social. Ainda que essas teorias, mais ou menos evolucionistas, fossem relativas a todas as sociedades humanas, a teoria social tendia a assinalar uma grande diferença entre o caráter dinâmico das sociedades ocidentais e a natureza imóvel das sociedades não-ocidentais. Uma das principais questões formativas da sociologia clássica - por que o capitalismo industrial emergiu inicialmente no Ocidente? - sustenta-se sobre um sistema explicativo que parte desse contraste fundamental entre sociedades ocidentais e os seus outros. Dito de outra maneira, a estrutura de referências e atitudes eurocêntrica, na Idade Moderna, foi erigida em torno de uma distinção entre o caráter dinâmico do Ocidente e o caráter estacionário das sociedades não-ocidentais (Turner, 1994: 22).

Hegel fornece em sua Filosofia da História - em grande sintonia com autores como Montesquieu e John Stuart Mill - um exemplo paradigmático dessa forma de representar o Oriente, exemplar e, posteriormente, inspiradora do discurso sociológico da modernidade. Em Hegel, o estudo das sociedades não-européias adquire uma variedade de sentidos complementares ${ }^{17}$. É bastante comum a consideração de Hegel como o primeiro grande "pensador da modernidade", no sentido de que ele foi o primeiro a erigi-la como problema filosófico fundamental (ver

${ }^{17}$ É evidente que não posso desenvolver aqui uma análise do sistema filosófico hegeliano tarefa para a qual eu não estaria preparado. Na verdade, não se pretendeu fazer isso com nenhum dos autores tratados até o momento. O objetivo é apenas apontar alguns dos elementos fundamentais da leitura de Hegel sobre as sociedades não-ocidentais e a forma como essa leitura se inscreve na tradição eurocêntrica que procuro aqui descrever. Para isso, baseio-me, em especial, em Arantes (2000: $2^{\underline{a}}$ parte, capítulo 1). 
Habermas, 2002). Nesse intuito de pensar filosoficamente a modernidade, Hegel formula uma teoria da história que, em grande medida, pode ser lida como uma das mais acabadas sublimações de uma concepção eurocêntrica do desenvolvimento histórico, entendida como realização progressiva da liberdade. Como aponta Bobbio, a contraposição hegeliana entre liberdade e despotismo corresponde, em grande medida, ao contraste entre Ocidente e Oriente (Bobbio, 1996: 150). A fórmula de Hegel, apresentada em suas preleções sobre a História Universal, é bastante conhecida:

“...pode-se dizer que a história universal é a exposição do espírito, tal como ele pelo seu labor consegue chegar a saber o que em si é. Os Orientais não sabem que o espírito ou o homem como tal é em si livre. Porque não o sabem, não o são. Sabem apenas que um é livre; mas, justamente por isso, semelhante liberdade é apenas capricho, barbárie, apatia da paixão ou também doçura e mansidão sua, a qual é somente um acaso ou arbítrio da natureza... Com o que eu disse em geral acerca da diferença que existe no conhecimento da liberdade - e claro está, primeiro na forma de que os Orientais apenas souberam que um é livre, o mundo grego e romano que alguns são livres, mas nós sabemos que todos os homens são em si livres, que o homem é livre - dispomos já da divisão que faremos na história universal e segundo a qual a abordaremos" (Hegel, 1991: 58-9).

Em Hegel, observa Arantes, a História - o próprio desenrolar da racionalidade - é o solo universal da experiência; ela só se precisa à luz das instâncias que recusa, o "fundo neutro e indiferenciado da não-história" (Arantes, 2000: 187). Para essa narrativa da história, Hegel ordena as sociedades através de uma noção de progresso, partindo de uma distinção entre sociedades "históricas" e "sem-história" - entre estas, encontram-se tanto os "povos primitivos" quanto sociedades como a Índia e China.

A não-racionalidade, no esquema hegeliano, é descrita sob o signo da não consciência. A passagem à História representaria o abandono do reino do imediato e a entrada em um processo de "tomada de consciência", ao se iniciar uma etapa de desdobramento reflexivo. Essa etapa reflexiva se materializaria em uma série de 
instituições e práticas - a dizer, os próprios fenômenos que presidem a instauração da história, como o Estado, a escrita alfabética e a prosa atrelada às funções da memória (ver Arantes, 2000: 191-4).

Os casos da Índia e da China são fundamentais para Hegel - e, no estudo de ambas, ele não se afasta da tradição eurocêntrica de seu tempo. Para cada uma dessas sociedades, Hegel desenvolve o raciocínio em torno de um dos elementos do discurso eurocêntrico: a China, um verdadeiro império imóvel, é descrita a partir da idéia de "despotismo oriental". A Índia, por sua vez, é descrita como mergulhada em uma espécie de sono informe, uma situação muito próxima a que poderíamos descrever como "encantamento"; nesse sono profundo, a Índia seria o reino do desejo, da fantasia e dos sentimentos (ver Arantes, 2000: 196) ${ }^{18}$. Mesmo compartilhando princípios diferentes, as conseqüências desses traços decisivos nas duas sociedades é inequívoco: "A China e a Índia permanecem estacionárias e perpetuam uma existência vegetativa natural até os dias presentes" (citado em Anderson, 1985: 466).

Em vez de uma história, essas sociedades viveriam uma perpétua reaparição do mesmo: a existência dessas sociedades é um curso uniforme, reprodução de um equilíbrio dado desde sempre. Elas seriam o reino da duração o tempo seria próprio do reino da história. Pode-se afirmar, seguindo Arantes, que a distinção entre tempo e duração corresponde à cisão entre História e não-história. Nas sociedades não ocidentais e a-históricas, não teria havido uma "internalização do devir": nenhuma oposição diferencial teria sido capaz de desencadear um processo de mediação; dessa forma, o antes e o depois permanecem indiscerníveis (Arantes, 2000, 1985: 211). Dessa maneira, a filosofia da história (assim como a filosofia da religião) de Hegel baseava-se em uma desigualdade hierárquica das culturas e religiões mundiais. Como aponta Susan Buck-Morss (2000: 858-859), as preleções de Hegel sobre a história e a religião sinalizam uma ruptura com relação à sua visão da história universal e, especificamente, a história colonial que marca seus escritos anteriores, e particularmente Fenomenologia do Espírito ${ }^{19}$. Sua

18 "[India] has always been the land of imaginative aspiration, and appears to us still as a fairy region, an enchanted world. In contrast with the Chinese state, which presents only the most prosaic understanding, India is the region of phantasy and sensibility" (Hegel, 1952: 219).

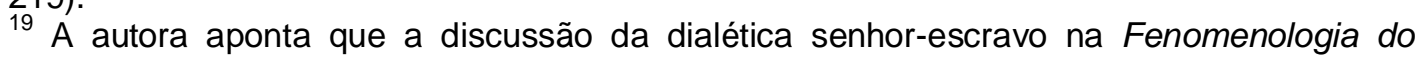
Espírito seria uma resposta direta à escravidão atlântica e à revolta de 1794 em São Domingos. Seus textos sobre história e religião, contudo, seriam marcados por uma visão 
filosofia da história e da religião reproduz uma imagem de mundo - ou seja, incorporaria e desdobraria elementos de uma estrutura de atitudes e referências que organiza a história da humanidade a partir de uma consideração da superioridade ocidental.

Marx não se afasta do tom da época ao descrever o Oriente como estático. Sua categoria de "Modo de Produção Asiático" é desenvolvida exatamente para explicar os motivos por que, em suas palavras, a "sociedade indiana não tem nenhuma história" ou "a China vegetava contra o tempo" (Anderson, 1985: 475). A inexistência de forças intermediárias entre as aldeias que se auto-reproduziam "em baixo" e a o Estado "hipertrofiado" "em cima", somada à posse estatal da terra, levaria a que a história do Oriente fosse essencialmente cíclica. Já foi anteriormente observado que o fundamental para a fixação dessa visão do Oriente em Marx é o fato de que este não constitui seu objeto particular de análise, mas sim um contraponto para a explicação de processos sociais que transcorriam no Ocidente sobretudo, a ascensão do capitalismo industrial. Algo semelhante se pode observar com relação a Weber. Apesar de este ter dado grande atenção ao estudo das sociedades asiáticas, isso se dá, sobretudo, como meio de compreensão das especificidades do desenvolvimento da racionalidade ocidental (ver Love, 2000: 172). Weber, além disso, é ambíguo ao longo de sua obra quanto ao caráter estacionário das sociedades orientais. Se em sua sociologia sistemática (Economia e Sociedade) Weber descreve o patrimonialismo como um sistema instável, aberto a disputas internas e à transformação (Kuper, 1989: 31), em sua sociologia comparativa das religiões Weber abre enormes espaços para a equiparação de seu esforço teórico com a tradição eurocêntrica da história oriental imóvel - e, mais uma vez, seu estudo da China é o caso mais representativo.

Como se vê, as razões de dinâmicas sociais tão distintas deveriam, em acordo com o mesmo discurso, ser buscadas no interior dessas sociedades. Algum traço interno a elas - formas de organização do poder, presença ou ausência de

muito menos crítica com relação à escravidão, descrevendo a África, em diversas passagens, como uma "terra de crianças" e de barbárie. Como aponta Buck-Morss (2000: 859): "Notoriously condemning African culture to prehistory and blaming the Africans themselves for New World slavery, Hegel repeated the banal and apologetic argument that slaves were better off in the colonies than in their African homeland, where slavery was "absolute" and endorsed gradualism: 'Slavery is in and for itself injustice, for the essence of humanity is Freedom; but for this man must be matured. The gradual abolition of slavery is therefore wiser and more equitable than its sudden removal'" 
leis escritas, existência de cidades ou propriedade privada da terra e, sobretudo, padrões culturais - seria responsável por traçar seus destinos históricos.

Nos principais textos da tradição eurocêntrica que busquei descrever, a caracterização das sociedades não-ocidentais como imóveis geralmente encontrase ligada à descrição do "despotismo oriental" ou de formas de vida e racionalidade "tradicionais", não metódicas. Traços típicos dessa forma de organização social ou dessas formas de vida forneceriam os princípios para a "explicação depreciativa" do caráter vegetativo dessas sociedades. Esses traços seriam os próprios bloqueios à transformação, a que vim me referindo até aqui. A percepção da existência de algum desses entraves - ou a elevação de qualquer um deles ao estatuto de princípio explicativo geral das formas de organização de uma determinada sociedade - torna-se o ponto de partida para a construção narrativa da imobilidade histórica de uma determinada sociedade não-Ocidental.

Essa estrutura de atitudes e referências que foi brevemente descrita neste trabalho constitui o núcleo da tradição eurocêntrica de maior impacto na constituição das Ciências Sociais modernas. Isso não é o mesmo que dizer que ela "determinou" ou "forneceu as condições de possibilidade" da reflexão sobre a modernidade (ou os obstáculos a ela) em contextos periféricos. Tomando distância do determinismo deste linguajar estruturalista extremado da primeira crítica acadêmica pós-colonial, creio que uma estratégia analítica de maior relevância é a observação das formas como essa estrutura, internamente bastante diversa e elaborada ao longo dos últimos séculos, foi apropriada (e, dessa forma, reelaborada e renovada inúmeras vezes) em contextos específicos - mesmo por autores nãoeuropeus que, de maneira alguma, poderiam ser entendidos como cúmplices diretos de uma estratégia imperialista ocidental.

A análise dos discursos sobre o drama da modernidade em sociedades periféricas, a partir de uma consideração acerca das apropriações de formas e categorias de pensamento eurocêntricos, pode ser de grande valia na elucidação sobre as maneiras como um "olhar central" forneceu pontos de partida para uma reflexão sobre a identidade e os destinos de sociedades não centrais. 
Para além disso, creio que essa análise ajuda-nos a refletir acerca da possibilidade de uma consideração da modernidade a partir de um outro olhar, este lançado a partir de perspectivas não contempladas por aquele pensamento eurocêntrico que procurei esquematizar. Em outros termos, a crítica ao pensamento eurocêntrico deve ser complementada por uma reflexão sobre as possibilidades de uma crítica à modernidade lançada a partir de uma perspectiva periférica - um exercício teórico e político que, entendo eu, define o próprio programa crítico de pesquisa pós-colonial. 


\section{Pensamento Eurocêntrico e os dilemas da modernidade no Brasil e nas sociedades árabes e muçulmanas}

"A cultura ibérica, que é a cultura do privilégio; a cultura africana, que é a cultura da magia; e a cultura indígena, que é a cultura da indolência. Com esses ingredientes, o desenvolvimento econômico é uma parada..."

Roberto Campos, $1991^{20}$

"..we should be confident of the superiority of our civilization, which consists of a value system that has given people widespread prosperity in those countries that embrace it, and guarantees respect for human rights and religion. This respect certainly does not exist in Islamic countries. [Therefore], the West is bound to occidentalize [the rest of the world] and conquer new people. It has already done it with the communist world and part of the Islamic world, but unfortunately part of the Islamic world is still 1,400 years behind. From that point of view, we must be conscious of the strength and force of our civilization..."

Silvio Berlusconi, $2001^{21}$

Em um trabalho bastante polêmico, o historiador indiano Dipesh Chakrabarty, ligado à corrente conhecida como "Estudos Subalternos", buscou demonstrar que, no discurso histórico tradicional, a Europa é a soberana de "todas as histórias" mesmo da história "da Índia", "da China" ou de qualquer outra sociedade não européia. Chakrabarty articula, com esse raciocínio, uma contundente provocação, de forma bastante consciente. O historiador aponta uma tendência de que todas essas histórias nacionais particulares se tornem variações de uma narrativa mestra - a própria narrativa da história da Europa -, que alocaria cada uma dessas histórias nacionais em uma posição de subalternidade (Chakrabarty, 2000: 27).

Esse traço eurocêntrico da narração da história da modernidade forneceria o pano de fundo para várias manifestações do exercício intelectual voltado à compreensão da história dessas sociedades. Uma dimensão, digamos, mais

${ }^{20}$ Citado em Werneck Vianna (1997: 190).

${ }^{21}$ Citado em Hassan (2001: 13). 
epidérmica desse fardo eurocêntrico é observável cotidianamente nos currículos escolares e nas agendas de pesquisa ao redor do mundo: especialistas nas sociedades centrais podem refletir sobre a história de suas sociedades com relativa ignorância em relação às histórias não-ocidentais, sem que isso pareça afetar a qualidade de seus trabalhos (Chakrabarty, 2000: 28); a ignorância simétrica, contudo, é considerada uma falha imperdoável na formação do pesquisador, ou o ranço de um nacionalismo "old-fashioned".

Contudo, essa não é a manifestação fundamental do caráter eurocêntrico da maior parte da historiografia e das Ciências Sociais produzidas no mundo. O problema fundamental refere-se às formas de pensar que orientam a narrativa da modernidade (e das possibilidades da "transição" a ela) a partir das quais cada uma das histórias nacionais é investigada. Nesse sentido, apenas a história da Europa, aquela narrative mestra a que se refere Chakrabarty, sería passível de formulação teórica: "only 'Europe', the argument would appear to be, is theoretically (that is, at the level of the fundamental categories that shape historical thinking) knowable; all other histories are matters of empirical research that fleshes out a theoretical skeleton that is substantially 'Europe'” (Chakrabarty, 2000:29; destaque no original).

Chakrabarty, de forma bastante astuta, descreve um problema fundamental: grande parte do conhecimento gerado sobre sociedades não-ocidentais (ou sobre sociedades periféricas) é resultado das tentativas de acomodação da história dessas sociedades a uma estrutura de atitudes e referências - cujo núcleo busquei descrever no capítulo anterior - que assegura dignidade histórica real a apenas uma experiência de realização da modernidade (seja em seus aspectos reais ou idealizados) - a experiência européia ou ocidental. Só esta, nos termos do historiador indiano, poderia ser pensada teoricamente - as outras, seguindo-se um raciocínio eurocêntrico, podem ser narradas como "estudos de caso", variações de um modelo ou como exemplos de fracassos históricos, segundo uma teoria da história centrada na idéia de "transição" à modernidade. "Fracassos", diga-se de passagem, tanto da sociedade em geral, descrita como presa a um mundo tradicional - como veremos a seguir - quanto de atores específicos, como, por exemplo, a "burguesia nacional", incapaz de levar a cabo seu "desígnio histórico revolucionário". Esse tipo de raciocínio, que permeia as ciências sociais de países periféricos, é uma demonstração da epistemologia "idealista" derivada de uma apropriação de narrativas eurocêntricas da modernidade - o cientista imputa ao ator 
uma ação condizente com a teoria, sendo esta pensada a partir de um imaginário europeu da modernidade.

Em uma outra linguagem, Chakrabarty parece corroborar as conseqüências de uma afirmação que atravessa a história do pensamento social em nações periféricas: não teríamos sido contemplados pelos clássicos - a não ser, poderíamos dizer, como formas diversas de habitar o pólo negativo das dualidades que orientaram a reflexão sobre a modernidade, que teria a Europa (ou o Ocidente) como sujeito.

A somatória dos "obstáculos" próprias à estrutura lógica e categorial eurocêntrica é parte fundamental de uma história de fracassos da transição ao moderno - uma história que só pode ser narrada após a definição de um pólo que poderia assumir a condição de modelo de modernidade. A história da transição e dos bloqueios, apropriada de formas diversas para narrar a história de coletividades não-européias, tem como sujeito a Europa.

Não há, certamente, apenas uma maneira de constituir uma história dos bloqueios na descrição de sociedades não-centrais, como tentei mostrar no capítulo 1 e continuaremos a ver neste capítulo. Os "Estudos Subalternos" indianos, uma das vertentes próxima a uma agenda de estudos pós-colonial, desenvolve, em seus primeiros estudos, uma crítica às formas depreciativas de abordar a ação camponesa na história indiana, inspiradas em raciocínios eurocêntricos. Cito o próprio Chakrabarty:

"There is, then, this double bind through which the subject of 'Indian' history articulates itself. On the one hand, it is both the subject and the object of modernity, because it stands for an assumed unity called 'the Indian people' that is always split in two - a modernizing elite and a yet-to-be modernized peasantry... The mode of self-representation that the 'Indian' can adopt here is what Homi Bhabha has justly called 'mimetic'. Indian history, even in the most dedicated socialist or nationalist hands, remains a mimicry of a certain 'modern' subject of 'European' history and is bound to represent a sad figure of lack and failure. The transition narrative will always remain 'grievously incomplete* (Chakrabarty, 2000: 40; destaque meu). 
Incompletude parece-me, dessa forma, um termo-chave nessa discussão, uma vez que ele sintetizaria o pólo negativo das dicotomias em torno das quais se articulam as várias versões do discurso eurocêntrico da modernidade. Esta - a modernidade - como forma de síntese da auto-percepção ocidental sobre sua história, é descrita sob o signo da completude, contraposta a diversas formas de incompletudes próprias aos outros dessa auto-percepção.

Creio que essas considerações sobre a centralidade do "sujeito" europeu na narrativa hegemônica da modernidade colocam um permanente dilema para as formas diversas de sua apropriação: como se pode pensar (e de fato se pensou) a modernidade em sociedades periféricas a partir de uma estrutura de referências que define esse objeto como o "não-moderno"? Não parece haver uma resposta geral a esse tipo de dilema. Como veremos a seguir, essa estrutura de atitudes e referências foi apropriada de formas diversas, perfazendo uma espécie de plataforma a partir da qual se buscou pensar os desafios, dilemas e possibilidades do moderno em sociedades periféricas. Assim, não tento aqui reduzir todas essas sociedades em uma imagem uniforme do "outro do Ocidente": em cada uma delas, devido às suas formações históricas particulares, a questão da modernidade se colocou de maneira específica, encaminhando-se diferentes usos daquele modelo histórico.

Os casos do Brasil e das sociedades muçulmanas, estudados paralelamente, fornecem um interessante quadro para uma comparação dessas apropriações. Não há como negar que essas sociedades tiveram histórias bastante diversas como "outro do Ocidente": para dizer o mínimo, o Brasil nasce do próprio contato com o colonizador europeu, tendo de enfrentar, permanentemente, o questionamento sobre sua identidade - ocidental e não-ocidental, ao mesmo tempo. Como colônia nas Américas, o Brasil é parte desse grande outro europeu da "primeira modernidade", como apontamos acima, sendo parte de uma região que nasce como periférica - com a especificidade de ter sido colonizada por Portugal, nação tida, no interior da Europa, como das "menos européias". O Mundo Muçulmano, por sua vez, constituiu, a partir do século VII, um imenso império (na verdade, uma série 
deles) ${ }^{22}$ em que vigorava uma importante fé "não-ocidental" e que, em diversos momentos, representou ameaças militares e culturais reais aos povos da Europa; impérios que, por sua proximidade e poder, representaram um outro fundamental para a Europa moderna (sobretudo nos séculos XVII e XVIII); e, por fim, impérios que, nos últimos três séculos, tiveram de enfrentar o problema político e intelectual da decadência frente a potências européias em constituição e, mais recentemente, as conseqüências de um alegado fracasso das tentativas de modernização levadas a cabo por diversas elites modernizadoras pós-coloniais, no século XX.

\section{Eurocentrismo e o Mundo Árabe e Muçulmano}

Grande parte dos autores que foram apresentados no primeiro capítulo utilizaram sistematicamente exemplos da história dos povos árabes e muçulmanos como forma de exemplificar a distinção entre os destinos históricos da Europa e dos povos não-europeus. Em grande medida, a proximidade entre o Império TurcoOtomano e o continente europeu justificou essa posição central da alteridade muçulmana no desenvolvimento da identidade européia a partir da Idade Moderna. Nesse sentido, a escolha de Said em Orientalismo - buscar descrever a formação do discurso da alteridade européia, focando-se nas imagens a respeito de povos árabes e muçulmanos que se desenvolveram na cultura ocidental, especialmente nos séculos XVIII e XIX - não deixa de ter mérito, apesar das críticas que já apresentamos anteriormente. A "proximidade" muçulmana incentivou o desenvolvimento de uma identidade do europeu como "não-muçulmano" e a descrição dessas sociedades árabes e muçulmanas como pólo antagônico do moderno ser europeu em constituição.

Essa posição de destaque das sociedades árabes e muçulmanas no desenvolvimento da estrutura de atitudes e referências eurocêntricas, sobretudo nos chamados "clássicos do pensamento ocidental", foi bastante analisada pela recente literatura de crítica ao eurocentrismo (Said, 2003 e 1995; Turner, 1989 e Bobbio, 1996). Dessa forma, creio ser mais proveitoso concentrar-me na obra de alguns dos mais influentes autores contemporâneos - árabes (como Fouad Ajami) e

\footnotetext{
${ }^{22}$ Não há, evidentemente, como sintetizar essa história de 14 séculos neste trabalho. Como introduções gerais a ela, remeto aos trabalhos de Demant (2004) e Hourani (2006).
} 
ocidentais (como Bernard Lewis e Ernest Gellner) - que se debruçaram sobre a história dessas sociedades a partir de apropriações diversas dos discursos eurocêntricos. Essa escolha também nos ajuda a observar como as estruturas lógicas e categoriais descritas anteriormente continuam sendo apropriadas para pensar os problemas da modernidade (ou da pretensa ausência dela) nessas sociedades.

$\mathrm{Na}$ academia norte-americana, poucas áreas passam, atualmente, por um período de maiores disputas acadêmicas e políticas do que os estudos sobre o Oriente Médio e o mundo muçulmano. Isso se deve tanto à existência de tradições de estudos da região bastante contrastantes - cujos partidários, ao longo das últimas décadas, travaram um duro debate teórico e ideológico - quanto à densidade que hoje essa região ocupa na política externa dos Estados Unidos, sobretudo a partir dos atentados de 11 de setembro de 2001. Um das tradições de maior destaque é a chamada "escola internalista" - também chamada de "culturalista" ou "essencialista" -, no interior da qual se destacam autores como Bernard Lewis, Fouad Ajami, Daniel Pipes, Martin Kramer e - de forma menos precisa quanto à propriedade da classificação de seus argumentos como "internalistas" - Fareed Zakaria e Bassam Tibi. Essa "escola" é aquela que mais se aproxima de uma caracterização eurocêntrica para a tentativa de compreensão daquelas sociedades, seja pelos estilos narrativos, pelo ponto de vista de um internalismo culturalista ou pelas categorias mobilizadas.

Tratarei, por hora, da obra de alguns dos mais influentes (intelectual e politicamente) acadêmicos contemporâneos que tratam das sociedades árabes e muçulmanas, buscando mostrar as maneiras como eles mobilizam elementos dos discursos eurocêntricos que procurei sintetizar.

\section{Bernard Lewis}

Bernard Lewis é um dos mais conhecidos especialistas em Oriente Médio dos Estados Unidos, tanto entre o público especializado quanto não especializado. Professor Emérito de Estudos Orientais na Universidade de Princeton, Lewis é o mais importante dos autores culturalistas das últimas décadas - uma definição usada pelos seus críticos, diga-se de passagem. Lewis teve seus trabalhos 
analisados já em Orientalismo, por Edward Said, autor com quem travou importantes discussões sobre o Oriente Médio e sobre os estudos dessa região ${ }^{23}$. Lewis é um dos acadêmicos que, nos últimos anos, mais vigorosamente se colocaram a favor de uma intervenção norte-americana no Iraque. Este é um dos motivos para a atual visibilidade de Lewis, muito além dos muros da academia. Porém, essa observação não nos deve confundir: Lewis é considerado, por muitos, o "decano" dos estudos sobre o Islã nos Estados Unidos, tendo formado gerações de especialistas em assuntos do Oriente Médio e do Islä ${ }^{24}$, além de ser um dos orientalistas mais traduzidos no mundo ${ }^{25}$.

Nas obras em que busca analisar o Islã e as sociedades árabes contemporâneas, Lewis parte da constatação de que essas sociedades passam por uma profunda crise, cujas raízes estendem-se profundamente no passado. Essa crise teria como causa, sobretudo, a forma como essas sociedades relacionam-se com sua fé e como essa impacta nas formas de absorção de instituições da "modernidade ocidental", ou seja, ela se estenderia aos principais elementos que constituem a cultura desses povos. Sua vasta e influente obra pode ser lida como uma reflexão (incrivelmente erudita, diga-se de passagem) sobre a não realização da modernidade ocidental entre os povos muçulmanos ${ }^{26}$. A narrativa que organiza o raciocínio do historiador é a narrativa dos obstáculos à modernidade - os "objetos" de Lewis, as sociedades árabes e muçulmanas, vão sendo desveladas como um ainda não. Trata-se, no que há de fundamental, de uma narrativa da incompletude

${ }^{23}$ Ver, por exemplo, Said (2002 e 2003) e Lewis (1993).

${ }^{24} \mathrm{Um}$ de seus alunos mais combativos, Martin Kramer, descreve bem (em tom louvatório, evidentemente) a enorme influência de Lewis na academia e na opinião pública norteamericanas e européias: "Over a 60-year career, Bernard Lewis emerged as the most influential postwar historian of Islam and the Middle East. His elegant syntheses made Islamic history accessible to a broad public in Europe and America. In his more specialized studies, he pioneered social and economic history and the use of the vast Ottoman archives. His work on the premodern Muslim world conveyed both its splendid richness and its smug self-satisfaction. His studies in modern history rendered intelligible the inner dialogues of Muslim peoples in their encounter with the values and power of the West. While Lewis' work demonstrated a remarkable capacity for empathy across time and place, he stood firm against the Third Worldism that came to exercise a broad influence over the historiography of the Middle East. In Lewis' work, the liberal tradition in Islamic historical studies reached its apex" (Kramer, 1999). Para uma análise da atual influência de Lewis na formação de uma visão política e academicamente hegemônica sobre o Oriente Médio, ver Hirsh (2004).

${ }^{25}$ Inclusive no Brasil. Em um país em que pouquíssimas obras estrangeiras sobre as sociedades orientais são traduzidas, uma porção significativa dos trabalhos de Lewis preenche as prateleiras de nossas livrarias. Este é um dos motivos pelos quais este autor receberá uma atenção especial neste trabalho.

${ }^{26}$ Para Lewis, a grande exceção a essa crônica do fracasso da modernidade entre as sociedades muçulmanas seria a Turquia, como veremos mais à frente. 
dessas sociedades - incompletude que só pode existir frente a um paralelo histórico de completude, que lhe sirva de parâmetro teórico e valorativo.

A duplicação do discurso é presença marcante em todos os escritos de Lewis consultados, instrumento narrativo fundamental para a construção de seu argumento. Os exemplos são vários, mas fiquemos com dois: a seção final daquele que é provavelmente seu mais conhecido livro, O Oriente Médio (1996), é intitulada "O desafio da modernidade". A modernidade aparece, como no restante do livro, como um outro tentando fixar-se em meio a uma sociedade que the impõe obstáculos incontáveis. Desafio de um lado, modernidade de outro. E modernidade como instituições e formas de vida ocidentais, que se irradiam pelo globo, destruindo modos de vida "atrasados" ou "tradicionais" - a não ser que encontre em seu caminho obstáculos, como crenças religiosas de difícil adaptação. Um segundo exemplo é o título de um de seus livros mais recentes, que bem caracteriza o teor de toda a obra, O que deu errado no Oriente Médio? (2002). O "erro" é todo ele explicado em termos de proximidades e distâncias com relação a um outro "moderno", "avançado". O erro, no linguajar do historiador, é a distância entre "eles" e "nós".

Para compreender sua abordagem das sociedades muçulmanas contemporâneas e sua consideração sobre os bloqueios à modernidade próprios àquelas sociedades, é necessário resumir sua análise sobre como essa crise ter-seia constituído. Lewis busca mostrar, em diversas passagens, que o Islã, em si, não seria incompatível com o desenvolvimento dessas sociedades: foi no interior dessa civilização que teria havido o maior desenvolvimento cultural, científico e artístico de todo o mundo ao longo da Idade Média. Contudo, esse quadro teria se alterado lentamente ao longo dos últimos quatro séculos, quando o Islã - aqui, no sentido civilizacional - passou a sofrer uma série de derrotas e a confrontar-se com instituições inventadas no Ocidente que se mostravam mais eficazes política, militar e economicamente. Pontos simbólicos iniciais dessas derrotas foram, para Lewis, o Tratado de Carlowitz, de 1699 - assinado entre o Império Otomano derrotado e a Santa Liga européia - e a ocupação do Egito por Napoleão Bonaparte, em 1798. Essas derrotas teriam forçado os povos muçulmanos a se perguntarem sobre os motivos de seu atraso frente aos ocidentais. Lewis afirma, entretanto, que a maioria das respostas para essa pergunta tendiam, já nos séculos XVIII e XIX, a destacar a necessidade de um retorno ao Islã puro, de cujos fundamentos os povos 
muçulmanos teriam se distanciado, provocando seu enfraquecimento frente aos “infiéis” (Lewis, 2002: 55). Referindo-se ao século XVIII, Lewis afirma:

\begin{abstract}
"O declínio dos otomanos, porém, deveu-se não tanto a mudanças internas, mas sim à incapacidade deles de acompanhar o rápido avanço do Ocidente em ciência e tecnologia, nas artes da guerra e da paz, e no governo e comércio. Os líderes turcos estavam bem conscientes dos problemas e tinham algumas boas idéias para solucioná-los, mas não conseguiam vencer as imensas barreiras institucionais e ideológicas à aceitação de novos costumes e novas idéias. Ou como disse um ilustre historiador turco: 'A onda científica quebrava-se contra os diques da literatura e da jurisprudência'”. (Lewis, 1996: 259; destaque meu).
\end{abstract}

Lewis admite ainda que, mesmo quando aceitas pelas sociedades mediorientais, boa parte das inovações ou das experiências tecnológicas, políticas ou econômicas vindas do Ocidente foram utilizadas como maneiras de se ampliarem os mecanismos de dominação à disposição de regimes autoritários. Exemplo disso seria, para Lewis, a boa aceitação dos modelos fascista e nazista na década de 1930 - que, apesar de terem se desenvolvido na Europa, eram eminentemente antiocidentais. O mesmo teria se dado com a grande aceitação da economia socialista, ao menos na forma de uma grande intervenção do estado na economia - o que seria condizente, comenta Lewis, com a prática oriental de as pessoas se apoderarem do poder para obterem vantagens econômicas pessoais (Lewis, 2002: 75).

Dessa forma, as sociedades do Oriente Médio não teriam passado por um devido processo de modernização aos moldes ocidentais. Como se pode perceber, Lewis destaca que esse processo não teria ocorrido principalmente devido a barreiras sociais e, sobretudo, culturais à modernização, presentes naquelas sociedades - haveria "diferenças cruciais em abordagem, atitude e percepção entre duas civilizações vizinhas" (Lewis, 2002: 78). A primeira barreira seria a forma como o Islã encara a condição da mulher na sociedade: ela não disporia de igualdade legal e religiosa no interior da comunidade islâmica, o que sustentaria a sua submissão. A emancipação das mulheres seria vista como a diferença crucial entre 
modernização - aceita até por alguns fundamentalistas radicais, segundo Lewis - e ocidentalização, já que constituiria uma violação dos verdadeiros valores islâmicos. A segunda barreira seria a relutância dos povos islâmicos em aceitar a ciência ocidental e, sobretudo, a filosofia a ela adjacente. A terceira barreira, simbolizada pela dificuldade da aceitação da música ocidental por aquelas sociedades ${ }^{27}$, é o insuficiente controle do tempo e seu uso efetivo na regulação das atividades cotidianas e daquelas reguladas pelo estado, em comparação com o Ocidente. Esses vários entraves descritos por Lewis adquirem um caráter de traços gerais das muitas sociedades árabes e muçulmanas (ou dos "povos das terras do Islã", como Lewis expressa em diversas passagens). Essa narrativa organiza-se em torno da idéia de obstáculos à modernidade, de forma bastante didática e eficiente: em alguns dos livros mais recentes de Lewis (2002 e 2004, por exemplo), a grande erudição do intelectual presta-se à construção de uma espécie de essência islâmica anti-moderna, a partir de uma somatória de casos e exemplos sobre como aquela civilização foi incapaz de absorver as instituições da modernidade (ou do Ocidente).

O ponto central da argumentação de Lewis está na forma como a "religião muçulmana" prescreveria a organização da sociedade. Para isto, Lewis "constrói" um Islã quase puro, inatingível pela dinâmica social e que parece se impor sobre qualquer quadro de estratificação social, a partir do qual se pode proceder a uma avaliação de adequação/inadequação com as instituições ocidentais. O secularismo - próprio dos estados ocidentais modernos -, por exemplo, não encontraria eco em uma civilização na qual a união de fé e política encontra-se presente desde sua fundação: "Maomé foi, por assim dizer, seu próprio Constantino" (Lewis, 2002: 115). O mesmo não se daria na cristandade, onde o preceito da separação do poder religioso e do secular já encontraria fundamento no ensinamento de Cristo sobre a distinção entre César e Deus. "Na organização política universal islâmica, tal como

${ }^{27}$ Tentando descrever um típico café em uma cidade do mundo árabe-muçulmano, Lewis aponta que "é muito improvável que se ouça qualquer tipo de música erudita ocidental. Mesmo entre os elementos mais ocidentalizados, social e culturalmente, a apreciação da música erudita é ainda muito limitada - em acentuado contraste com o Japão ou mesmo a China, outras sociedades não-ocidentais onde a música erudita de estilo ocidental é muito apreciada, executada e mesmo composta. ... a música é a última e a menos eficaz nos processos artísticos de ocidentalização. E esse fato, talvez, nos diga alguma coisa, uma vez que a música, entre as artes da civilização, é realmente a última que um estranho chegando de fora pode compreender, aceitar e executar" (Lewis, 1996: 28-29). A essa pergunta de Lewis de poderia devolver uma outra: com que freqüência toca-se "música erudita ocidental" em bares e cafés "ocidentais" - digamos, em Nova lorque ou Berlim? Contudo, outra forma, talvez mais eficiente, de responder a essa questão é apontar a já grande e crescente difusão do que se entende por música erudita no interior dessas sociedades. 
concebida pelos muçulmanos, não há César, apenas Deus, que é o único soberano e a única fonte de lei" (Lewis, 2004: 27). A verdade - e a tragédia - parecem estar prescritas na origem, em uma espécie de pecado original da revelação divina a Maomé que condiciona todo o futuro. É esse pecado original, que se reporia historicamente sem nenhuma espécie de quebra fundamental geral, forneceria o padrão de racionalidade e as formas de vida que se imporiam a um fluxo de modernização que nunca conseguiria se impor.

A construção dessa espécie de Islã imutável parece contradizer a argumentação de Lewis sobre a decadência "moderna" dos povos muçulmanos. Contudo, esses dois argumentos são, de fato, apenas aparentemente contraditórios: a "crise do Islã", observável nos últimos séculos, teria como causas profundas os preceitos fundamentais de organização dessas sociedades, e estes já estariam, em grande medida, definidos no ato fundacional da fé muçulmana: as seguidas referências ao texto do Corão por Lewis (e pelos orientalistas, em geral) atestam esse destino pré-determinado dessas sociedades (ver, por exemplo, 1988: 97). Lewis parece aceitar, em grande medida, a leitura fundamentalista do Islã ${ }^{28}$ (com um sinal trocado em termos valorativos, evidentemente), entendendo este como ente que prescreve hábitos e práticas de todos os tipos - desde as formas de relacionamento entre estado e sociedade como os padrões adequados de vestimentas -, ao longo dos séculos, com grande uniformidade. Essa é a forma como Lewis adere a uma narrativa da imutabilidade dessas sociedades. Suas transformações devem-se não a uma dinâmica interna entre grupos e classes em disputa material e simbólica ao longo do tempo, mas ao choque com um outro que se mostrou mais dinâmico: "A história moderna da região é de mudança rápida e imposta - de desafio feito por um mundo estranho e de diferentes fases e aspectos de reação, rejeição e resposta" (Lewis, 1996: 29). Internamente, ela possuiria poucos elementos dinâmicos que sustentassem um processo de grande transformação cultural e política. Essa essência muçulmana, construída por Lewis

${ }^{28}$ Um grande número de críticos aponta a semelhança entre as leituras de autores orientalistas e de muçulmanos fundamentalistas sobre suas sociedades: a estrutura da argumentação seria bastante semelhante, mas os preceitos de "resolução" dos problemas e os ideais de sociedade é que seriam opostos. Dissertando, por exemplo, sobre a não separação entre estado e fé no "islã clássico", Lewis afirma: "It was never so in the past, and the attempt in modern times to make it so may perhaps be seen, in the longer perspective of history, as an unnatural aberration that which in Iran has ended and in some other islamic countries may also be nearing its end" (Lewis, 1988: 2). Ver, para essa crítica, Halliday (1993) e Said (2002). 
ao longo de sua obra, funciona como uma enteléquia, um princípio explicativo geral (que convive com outros princípios, mas que assume uma carga explicativa determinante) para a história de um grande número de sociedades, ao longo de quatorze séculos. Em Lewis (e em praticamente todo o discurso eurocêntrico que trata das sociedades muçulmanas), o Islã, base dos princípios de ação individual e de solidariedade coletiva, não seria capaz de fornecer os preceitos de ação racional próprios à vida moderna, constituindo-se, dessa forma, como obstáculo para sua plena instalação.

Esse Islã "total" do discurso eurocêntrico de Lewis permite que ele realize uma espécie de síntese civilizacional, unificando sobre o conceito de Islã um grande número de povos, etnias e estados, em diferentes períodos históricos. Isso é bastante claro, por exemplo, em seu livro The Political Language of Islam (1988). Há que se reconhecer o livro como uma imensa demonstração de conhecimento histórico e filológico sobre as diversas sociedades muçulmanas, o que permite que Lewis caminhe com naturalidade por uma imensidão de textos árabes, turcos e persas. Contudo, os pressupostos que guiam esse esforço são reveladores. A partir do estudo de conceitos políticos utilizados ao longo dos séculos de história da civilização islâmica, Lewis procura analisar os preceitos da política e das formas de organização social que marcaram a história dessa civilização. É interessante observar que o historiador Fred Halliday, em sua crítica ao orientalismo, centra-se em uma característica fundamental desse discurso: a compreensão de que o estudo do mundo árabe e muçulmano equivale ao estudo de suas línguas e escritas, e que a compreensão da língua e dos textos tradicionais é o caminho para compreensão da sociedade e da política (Halliday, 1993: 151). Essa necessidade do estudo dos textos tradicionais resvala, com freqüência, em uma visão essencialista da história desses povos, segundo a qual todo o seu desenvolvimento no tempo estaria prescrito nas origens. Esse parece ser o grande pressuposto, mais uma vez, desse controverso - porém bastante influente - estudo de Lewis.

O que permite essa análise de Lewis, mais uma vez, é a sua visão do Islã como um sistema total, como um dado, e não um dos elementos de uma dialética social, passível de reelaborações conforme os diferentes contextos históricos e estruturações sociais. Dessa maneira, Lewis pode afirmar que “...from the time of the Prophet to the present day, the ultimate definition of the Other, the alien outsider and presumptive enemy, has been the kāfir, the unbeliever" (Lewis, 1988: 5). O livro 
organiza-se em torno da idéia de permanência - as transformações nas interpretações das leis sagradas e nas práticas sociais que organizam a vida política, apesar de serem apontadas, parecem pouco relevantes para a análise do autor. Seguindo a tradição do orientalismo clássico, Lewis realiza uma leitura bastante literal dos textos e práticas da tradição islâmica, sem se deter sobre os reais significados (sujeitos a mudanças e a reinterpretações) e as tensões em torno da doutrina islâmica. Afirmações do tipo "the sharī’a is simply the law, and there is no other. It is holy in that it derives from God, and is the external and unchangeable expression of God's commandments to mankind" (Lewis, 1988: 72) são bastante comuns no texto de Lewis, contribuindo para aquela narrativa da permanência. Essa narrativa é, no discurso eurocêntrico sobre as sociedades árabes e muçulmanas, a descrição da reiteração das origens, da busca das raízes (e o uso deste termo não é fortuito), profundamente incrustadas no passado, que já conteriam respostas bastante precisas sobre os males do presente. Sobre a jihād, Lewis pode afirmar:

"The classical Islamic discussions of the justified war and the laws which regulate its conduct relate most entirely to struggles against external enemies. The principle of war against the apostate, however, opened the possibility of legitimate, indeed obligatory, war against an enemy at home, which in modern times has been developed into a doctrine of insurgency and revolutionary war as a religion obligation and a form of jihād. This too has its roots deep in the Islamic past" (Lewis, 1988: 90).

Em suma, essas barreiras à modernização, constituídas de traços internos à cultura e à organização social dos povos muçulmanos, explicariam a crise em que eles se encontram. Lewis critica a visão de que o "atraso" dessas sociedades seria conseqüência da ação imperialista ocidental sobre elas. O Imperialismo europeu teria tido, na verdade, efeitos dúbios, tanto positivos quanto negativos - o que contrariaria a visão unidimensional sobre esse fenômeno presente nas mitologias nacionalistas da região (Lewis, 2004: 66). Este é um ponto importante da argumentação de Lewis, bastante representativa do que se costuma chamar de internalismo nos estudos sobre as sociedades médio-orientais, como veremos mais 
à frente. Lewis descreve em termos bastante brandos os motivos e conseqüências do domínio ocidental sobre as sociedades e territórios do Oriente Médio. Segundo ele,

"a Grã-Bretanha e a França dividiram o Crescente Fértil não em colônias e dependências, como nos velhos dias, mas em novos Estados, com novas fronteiras e nomes, que controlaram e administraram sob mandato da Liga das Nações, a fim de prepará-las para a independência. Nesses estados, estabeleceram regimes tomando como modelos os seus" (Lewis, 1996: 303; destaque meu) ${ }^{29}$.

O autor aponta ainda as vantagens econômicas trazidas pelo período de imperialismo (infra-estrutura, acesso a bens de consumo etc.) e as vantagens decorrentes do acesso desses povos às línguas ocidentais: “...as línguas inglesa e francesa, antes conhecidas apenas de uns poucos na região, com exceção do Egito e do Líbano. Com essas línguas veio o acesso ao mundo moderno, à sua cultura e à ciência. A introdução da ciência ocidental, ou, para ser exato, moderna, é em geral reconhecida como um ganho para os povos da região"30 (Lewis, 1996: 313). O resumo da história é descrito, por fim, como bastante positivo: "O grande serviço prestado pelo Oriente Médio ao Ocidente foi o fornecimento de bases e instalações de apoio à guerra contra o Eixo. E, em troca, o maior serviço do Ocidente ao Oriente Médio foi salvá-lo da experiência direta do domínio do Eixo" (Lewis, 1996: 314). As acusações contra os Estados Unidos igualmente não fariam sentido - não seria pertinente referir-se à atuação norte-americana no Oriente Médio como uma

\footnotetext{
${ }^{29}$ Lewis subscreve, como se vê, a tese eurocêntrica que vê a colonização como um processo "pedagógico", por meio do qual as potências ocidentais preparam os povos colonizados para suas independências futuras. O exercício imperialista, dessa forma, é descrito como uma empresa humanista e, digamos, filantrópica - o colonizador, sujeito de todo o processo, está na colônia, no limite, para descolonizá-la. Como aponta com precisão Linhares (2000), 'No seu nascedouro, a palavra 'descolonização' já vem carregada de ideologia, parecendo definir um destino Histórico dos povos colonizados: depois de ter colonizado, o europeu 'descoloniza', estando, pois, implícita a vontade do país colonizador de abrir mão de pretensos direitos adquiridos em determinado momento. A generalização do termo implica, de certa forma, uma interpretação eurocêntrica da História, ou seja, a noção de que só a Europa possui uma história ou é capaz de elaborá-la. Os outros não têm história: nem passado a ser contado nem futuro a ser elaborado".

${ }^{30}$ Nesta frase, a interessante confusão entre "moderno" e "ocidental" revela, de maneira sintomática, a posição eurocêntrica com relação à assumida equivalência entre modernidade e Ocidente.
} 
das causas fundamentais dos atuais problemas políticos e sociais da região. Lewis destaca que a oposição generalizada contra essa potência não deriva da reclamação contra determinadas políticas norte-americanas, mas representam uma "rejeição e uma condenação, ira e desprezo ao mesmo tempo, dirigidas a tudo o que os Estados Unidos parecem representar no mundo moderno" (Lewis, 2004: 81).

Frente a essa constatação de crise decorrente, sobretudo, de fatores endógenos, Lewis conclui que existem apenas duas respostas possíveis para esse dilema $^{31}$ :

\begin{abstract}
"Em nossos dias, duas respostas a essa questão recebem amplo apoio na região, cada uma envolvendo seu próprio diagnóstico do que está errado e a receita correspondente para sua cura. Uma, que atribui todo o mal ao abandono da herança divina do islã, defende o retorno a um passado real ou imaginário. Esse é o procedimento da Revolução Iraniana e dos chamados movimentos e regimes fundamentalistas em outros países muçulmanos. O outro procedimento é o da democracia secular, que tem sua melhor corporificação na República Turca fundada por Kemal Ataturk" (Lewis, 2002: 183).
\end{abstract}

Esse é o ponto central de onde parte a análise de Lewis sobre 0 fundamentalismo islâmico. Para ele, estaríamos vivendo em uma época em que o Islã inspira em alguns de seus seguidores sentimentos de ódio e violência, boa parte dos quais direcionados contra o Ocidente - e contra os Estados Unidos, em particular (Lewis, 1990). Isso seria conseqüência direta daquela série de derrotas sofridas pelos muçulmanos, que teriam levado naturalmente a um direcionamento do ódio primeiramente contra o inimigo milenar e a uma retomada de antigas crenças e lealdades, presentes em uma visão de Islã puro. Os Estados Unidos seriam centrais ao pensamento fundamentalista: eles representariam o exemplo máximo de uma civilização sem cultura, rica e confortável, materialmente avançada, mas artificial e desprovida de alma, mecânica e desprovida da espiritualidade e vitalidade presente em povos "autênticos" (Lewis, 1990). Esse pensamento fundamentalista, além de basear-se em uma leitura tradicional do Islã, também se

${ }^{31}$ Os dois movimentos dominantes no século XX, o socialismo e o nacionalismo, segundo o autor, já teriam sido descartados (Lewis, 2002: 183). 
basearia em ideologias anti-ocidentais diversas, em especial o nazismo, o marxismo e o terceiro-mundismo. O fundamentalismo muçulmano encontra-se em expansão, segundo Lewis, porque se aproveita de diversas vantagens e das condições históricas do tempo atual ("tensões crescentes, ideologias vacilantes, lealdades exauridas e instituições decadentes"), podendo, assim, fornecer:

"...uma base emocionalmente familiar para a identidade grupal, a solidariedade e a exclusão; uma base aceitável de legitimidade e autoridade; uma formulação imediatamente inteligível de princípios a serem usados tanto numa crítica do presente quanto num programa para o futuro. Através de tudo isso, o islã pode prover os símbolos e slogans mais efetivos para a mobilização, seja a favor de uma causa ou um regime, seja contra eles" (Lewis, 2004: 39).

Assim, o programa fundamentalista passaria por um combate ao Ocidente, visto como a fonte do mal que estaria corroendo suas sociedades. Em muitos casos, destaca Lewis, essa oposição exigiria um enfrentamento inicial dos próprios regimes de seus estados, como se deu na Revolução Iraniana. O segundo ponto desse programa é a idéia de um retorno à lei islâmica e ao autêntico modo de vida muçulmano, para o qual, novamente, a derrubada de governos apóstatas seria fundamental (Lewis, 2004: 40). Isso demandaria uma negação do secularismo, passando-se assim pela necessidade da abolição dos códigos legais importados e dos costumes sociais que teriam vindo com eles (Lewis, 2002: 124). Por último, como já expresso, o fundamentalismo visaria a um combate aos Estados Unidos. Lewis relembra, neste ponto, a influência da análise de Sayyd Qutb, para quem a degeneração e a libertinagem do modo de vida americano representariam a maior ameaça ao Islã (Lewis, 2004: 85). Em suma, segundo Lewis, os fundamentalistas islâmicos descreveriam os problemas do mundo muçulmano como derivados de um excesso de modernização, a qual representaria uma traição aos valores islâmicos. Novamente aqui, os Estados Unidos seriam vistos como a única força rival capaz de obstruir a disseminação divinamente ordenada do islã (Lewis, 2004: 126 e 146), daí se reforçando a necessidade de combatê-los.

Essas considerações de Lewis sobre o fundamentalismo muçulmano e sobre a persistência da democracia na região são orientadas pelo seu quadro geral de 
obstáculos à modernidade, exposto até agora. Nesse quadro, a cisão entre Oriente e Ocidente, atraso e modernidade, encontra uma exceção: a Turquia seria a única sociedade muçulmana que teria conseguido se desligar de suas amarras tradicionais e liberar-se para a modernidade. Mustafá Kemal Ataturk, o líder reformador turco, aparece como o exemplo de reformador radical - radical por realizar uma verdadeira troca de raízes sociais, eliminando assim (e "só assim"), os obstáculos à modernidade ${ }^{32}$ : "Ataturk, como sempre, foi direto até as raízes do assunto. 'Nós queremos usar roupas civilizadas' disse. Mas o que significa isso? E por que deveriam as roupas de civilizações muito mais antigas ser consideradas incivilizadas? Para ele, civilização significava civilização moderna, isto é, ocidental” (Lewis, 1996: 20). Ao descrever a Turquia, Lewis utiliza o recurso de internalizar o outro (moderno), gerando um modelo dualista que é uma extensão da cisão modernidade-Ocidente/atraso-Oriente original. Ataturk é o anti-Khomeini (ou o antiislâmico, este entendido como o indivíduo que partilha de formas de vida antimodernas), a resposta para a eliminação dos bloqueios auto-impostos. No texto de Lewis, bastante representativo do eurocêntrico do século XX, a defesa de Ataturk é, em essência, uma defesa do caráter anti-moderno do Islã.

Para concluir, deve-se lembrar da influente expressão trazida inicialmente por Lewis para o debate acadêmico e político sobre o Oriente Médio, nos últimos 18 anos: esse enfrentamento do fundamentalismo contra a modernidade - ou contra o que há de ocidental nela - configurariam, para Lewis, nada menos do que um "choque de civilizações"33.

"It should by now be clear that we are facing a mood and a movement far transcending the level of issues and policies and the governments that pursue them. This is no less than a clash of civilizations - the perhaps irrational but surely historic reaction of an ancient rival against our Judeo-Christian heritage, our secular present, and the worldwide expansion of both. It is crucially important that we on our side should not be

32 Hirsh (2004) desenvolve uma interessante análise a respeito do impacto sobre a produção histórica de Lewis de suas primeiras pesquisas, realizadas na Turquia, na década de 50. Ao que tido indica, Lewis foi o primeiro pesquisador ocidental a ter acesso integral aos documentos do governo otomano.

${ }^{33}$ Samuel Huntington (1993), em sua famigerada análise do mundo pós-Guerra Fria, deu enorme repercussão a esse termo utilizado inicialmente por Lewis. 
provoked into an equally historic but also equally irrational reaction against that rival" (Lewis, 1990).

Esse choque de civilizações, segundo Lewis, apesar de estar assentado atualmente em um contexto de supremacia Ocidental e um conseqüente ódio islâmico, representaria, na verdade, uma etapa avançada de um padrão histórico de confrontação entre esses dois sistemas: "The struggle between these rival systems has now lasted for some fourteen centuries. It began with the advent of Islam, in the seventh century, and has continued virtually to the present day. It has consisted of a long series of attacks and counterattacks, jihads and crusades, conquests and reconquests" (Lewis, 1990).

\section{Outras análises contemporâneas: Ernest Gellner e Fouad Ajami}

Essa análise da obra de Lewis - por mais sucinta que tenha sido, tendo em vista a dimensão da obra desse historiador - demonstra a variedade de aspectos históricos abertos a uma consideração a partir de uma matriz eurocêntrica de reflexão. Exemplarmente, Lewis consegue tratar de temas tão variados como a incorporação da tecnologia ocidental, a ausência de uma reforma protestante, a excepcionalidade da modernização turca e o islamismo radical, lançando mão inegavelmente, de forma "criativa" e "erudita" - de um sem número de narrativas teóricas que dispõem o Ocidente como sujeito.

Nos anos mais recentes - sobretudo a partir do final da década de 70, com a Revolução Iraniana -, um dos temas centrais na reflexão acadêmica, política e jornalística a respeito das sociedades muçulmanas foi o tema do "fundamentalismo" - ou do islamismo, no sentido das várias formas de mobilização da fé islâmica com objetivos políticos. Esse fenômeno vem sendo, em grande parte das análises, descrito como a manifestação fundamental do fracasso dessas sociedades em se modernizarem. Dada a importância do tema, apresento brevemente as análises de dois influentes acadêmicos sobre essa "crise" atual dessas sociedades.

Ernest Gellner, um dos mais eminentes antropólogos contemporâneos, assume uma perspectiva liberal e racionalista para avançar uma crítica ao fundamentalismo religioso (sobretudo islâmico) e ao relativismo pós-moderno - para 
ele, as duas grande ameaças ao racionalismo iluminista. Segundo o antropólogo, essas constituiriam as três opções fundamentais do espírito humano, irredutíveis entre si (Gellner, 1993). Gellner descreve o fundamentalismo como uma forma de exercício literal da fé, sem acordos ou concessões; nessa forma de vivência religiosa, a doutrina seria superior ao rito, sendo seguida na forma como foi fixada na escrita. O fundamentalismo repudiaria a noção moderna de religião e se basearia em uma afirmação do sobrenatural como expressão de lealdade à ordem social (Gellner, 1993: 2). O Islã seria, hoje, o grande depositário dessa manifestação religiosa, uma vez que teria imposto as maiores resistências à secularização - esta, um processo real e inquestionável da modernidade; dessa forma, "... there is one very real, dramatic and conspicuous exception to all this: Islam" (Gellner, 1993: 5).

Para explicar essa excepcionalidade do Islã, Gellner descreve uma série de características internas a essa fé religiosa: entre estas, ele destaca que no Islã haveria apenas leis divinas (as leis humanas seriam prevenidas pela divindade); além disso, fatos iniciais da história islâmica (como a cisão entre xiitas e sunitas) impactariam ainda vividamente os destinos dessas sociedades. Gellner preocupase enormemente em descrever os "males de origem" da crise contemporânea: a separação original de poderes conferida pela divindade não teria exigido um lluminismo - o Islã já disporia de uma divisão entre o "legislativo" divino e o "executivo" humano subordinado àquele. Essa característica original do Islã teria condenado esses povos a uma submissão constante aos sábios da lei, já que "a socially and politically transcendent standard of rectitude was ever accessible, beyond the reach of manipulation of political authority, and available for condemning the de facto authority if it sinned against it" (Gellner, 1993: 7-8). Para Gellner, esses preceitos iniciais do Islã levaram à ascensão de uma civilização bastante homogênea, dotada de um ideal e uma auto-imagem claramente definidos (Gellner, 1993: 8). Dessa maneira, a história do Islã pode ser narrada como uma série de ciclos e disputas em torno desses princípios - seja disputas entre autoridades "terrenas" e "religiosas" ou entre "baixo" e "alto" Islã (ver Gellner, 1993: 8-15) -, sem qualquer grande mudança real.

Gellner tenta aproximar a atual situação das sociedades muçulmanas das de outras sociedades subdesenvolvidas. Ele aponta que todas essas sociedades teriam vivido um dilema fundamental: elas deveriam emular os valores daqueles de 
cujo poder elas gostariam de se aproximar (abrindo mão da própria tradição) ou deveriam afirmar os valores da própria tradição, mesmo com os custos da fraqueza material $?^{34}$. Gellner aponta, sem surpresas, que a escolha do Islã foi um apego ferrenho à "tradição" - uma tradição avessa à onda moderna da secularização, segundo a descrição de Gellner.

A imagem do Islã que Gellner mobiliza para compor o quadro acerca da "encruzilhada" em que a humanidade se encontraria deriva-se, em grande medida, de alguns de seus estudos anteriores sobre sociedades islâmicas -sobretudo Muslim Society, de 1981. Na verdade, este livro retrata o Islã de forma muito menos inequívoca, buscando descrever, em algumas passagens, as diferenças internas às sociedades islâmicas e os diferentes impactos da modernização conforme os tipos de arranjos sociais anteriores. Gellner faz uma reconstrução etnográfica de diversas práticas e padrões sociais observados por ele ao longo de diversos anos, sobretudo em tribos e comunidades tradicionais muçulmanas do Norte da África. É inegável que Gellner fornece diversas contribuições extremamente relevantes para o estudo dessas sociedades tribais e para a relação entre elas e as comunidades urbanas, ao longo da história - mesmo a idéia de que haveria uma disputa histórica entre um Islã escrituralista e um Islã popular não é passível de apreensão a priori, servindo, em diversos momentos, para uma consideração do autor a respeito dos destinos da modernização em ambientes em que prevalece cada uma dessas formas da fé e em que as elites apresentam uma determinada formação ${ }^{35}$.

Entretanto, é interessante notar que Gellner, com grande freqüência, parece deslizar de sua própria descrição da diversidade interna para formular afirmações acerca de uma essência imutável do Islã - não é à toa que o título do livro nos fala de uma "sociedade muçulmana", e não de uma diversidade de sociedades de fé muçulmana. O sentido do título é clarificado no início do primeiro capítulo:

34 Esse tipo de dilema, para o caso das sociedades árabes e muçulmanas, foi exemplarmente analisado no já clássico livro de Alberto Hourani, O Pensamento Árabe na Era liberal (2005). Contudo, a análise de Hourani (e diversos outros trabalhos contemporâneos, como Espósito, 1997; Halliday, 1995 e Göle, 1993) procuram explorar as maneiras pelas quais essa "tradição" foi sendo retrabalhada por essas sociedades, de forma a permitir formas específicas de realização do moderno.

${ }^{35}$ Ver, por exemplo, a discussão de Gellner sobre a relação dos tipos de elite, dos padrões de colonização e do tipo primordial de conformação religiosa nas diversas sociedades predominantemente muçulmanas (Gellner, 2000 [1981]: 68-69). 
"Islam is the blueprint of a social order. It holds that a set of rules exists, eternal, divinely ordained, and independent of the will of men, which defines the proper ordering of society. This model is available in writing; it is equally and symmetrically available to all literate men, and to all those willing to heed literate men. These rules are to be implemented throughout social life" (Gellner, 2000: 1).

O Islã aparece como uma ordem social total, com mecanismos internos, divinamente revelados, que não seria passível de modificação - a mensagem divina, nota Gellner, seria completa e final, além de conter prescrições para a totalidade da vida social ${ }^{36}$. É notável que, descrevendo o Islã como uma doutrina completa desde o início, Gellner (assim como Bernard Lewis) assume - ou transforma em versão primordial - uma vertente do Islã muito próxima daquela dos chamados fundamentalistas religiosos, que pregam, em sua maioria, esse apego "inegociável" às fontes tradicionais (ver, para essa discussão, Halliday, 1995; Espósito, 1995; Espósito e Voll, 1996; Mahmood, 2005).

Vemos em Gellner, dessa forma, um movimento de ampliação da descrição etnográfica de processos sociais e práticas religiosas (ou religiosamente motivadas) em comunidades islâmicas se converterem em explicações totais da gramática das relações sociais de toda uma civilização - uma espécie de falácia de generalização sem devidas mediações, a qual um autor crítico a Gellner e ao culturalismo chamou de "antropologismo" (ver Hudson, 1995).

Como apontei anteriormente, a estrutura de referências eurocêntricas, que procurei descrever no capítulo anterior, não é apropriada apenas por autores ocidentais quando se voltam a sociedades não-ocidentais, mas constitui, igualmente, uma reserva de imagens, conceitos e estilos a partir dos quais os próprios não-ocidentais, em muitos casos e por diferentes razões, refletem sobre suas sociedades. Nos atuais debates políticos e acadêmicos sobre as sociedades muçulmanas, uma série de autores originários destas figuram entre as vozes mais

\footnotetext{
36 "Islam, through the doctrine that the lines of Prophets was completed, satisfies this logicalphilosophical requirement. No further increments to the Normative Truth are either possible or allowed. The logical point does not perhaps matter much. But sociologically it is extremely important. By firmly closing the door, in principle, to further additions to the Revealed doctrine, it enormously strengthens the hand of those who have Access to the delimited truth through literacy and who use it as a charter of legitimacy" (Gellner, 2000: 23).
} 
proeminentes a lançar mão desse arcabouço teórico, com impactos políticos evidentes - inclusive pelo fato de a origem normalmente ser entendida como sustentáculo da autoridade de seus discursos.

Fouad Ajami, cientista político libanês, Professor de Estudos do Oriente Médio na Johns Hopkins University, é um notório caso dessa "apropriação pelos nativos" daquela estrutura de referências. Importante estudioso do mundo árabe nos Estados Unidos, Ajami ganhou bastante espaço na mídia norte-americana a partir dos atentados terroristas de 11 de setembro, expondo opiniões contundentes a favor das ações norte-americanas no Afeganistão e no Iraque. Pode-se observar também uma grande alteração nas principais posturas desse intelectual a partir dos últimos anos, principalmente no que se refere à modernização dos estados árabes e do avanço de ideologias islamistas, o que fez com que seus trabalhos recentes, principalmente por destacarem o que ele trata como "patologias auto-infligidas da política e da cultura árabes", fossem vistos com reservas por boa parte da academia norte-americana (Lockman, 2005: 87).

Em suas intervenções mais relevantes ao debate público nos Estados Unidos, onde é radicado, Ajami parte da constatação de que as sociedades árabes passam atualmente por um período de enorme crise: "a darkness, a long winter has descended on the Arabs" (Ajami, 2001). O fundamentalismo islâmico é uma das conseqüências dessa crise, que pode ser descrita como conseqüência do fracasso do processo de modernização no interior dessas sociedades. Isso se refletiria atualmente no insucesso da democracia e no enfraquecimento do estado-nação no mundo árabe. Juntamente do fundamentalismo islâmico, como conseqüência dessa crise, ascenderia também o anti-ocidentalismo (ou o anti-americanismo, em particular).

Aqui se encontra o argumento central de Ajami: o repúdio ao Ocidente, comum entre os povos árabes do presente, é fruto do hábito de transferir a um outro a responsabilidade por uma crise cuja responsabilidade seria dos próprios árabes. Ter-se-ia disseminado no mundo árabe uma condição cultural congênita que evita tomar para si a responsabilidade pelas "feridas auto-infligidas" (Ajami, 2003). A crise da modernidade dessas sociedades, dominadas por líderes autoritários e marcada por movimentos contestatórios com ideologias islamistas, não seria responsabilidade de ninguém, senão deles próprios. Ele observa que, como em qualquer sociedade enfraquecida, o culto ao "bandido" que atinge os poderosos é 
muito sedutor no mundo árabe atual: os seguidos de líderes extremistas seriam os filhos enraivecidos de uma geração árabe fracassada (Ajami, 2001). Ajami tenta articular a crise da modernidade, o predomínio de regimes autoritários, a ascensão de grupos fundamentalistas e o anti-ocidentalismo (este último, a causa final do terrorismo contra alvos ocidentais) da seguinte forma:

"A terrible war was fought between rulers and Islamists; the regimes in Algeria, Tunisia, and Egypt won, but the insurgents took to the road, and vowed to return as triumphant conquerors after the dynasties and the despots were sacked. Rich, famous, free and young, bin Laden taunts the rulers of a silent, frightened Arab world seething with resentments of every kind. He and his lieutenants cannot overthrow the Arab ruling order, so they have turned their resentments on us" (Ajami, 2001).

Frente à constatação da crise de modernização devido a fatores unicamente internos - ou, ao menos, fundamentalmente internos -, os povos árabes se encontrariam um "beco sem saída" de sua história (Ajami, 2001). Contudo, Ajami constata que essa situação pode ser revertida por meio da ação das grandes potências na região com o objetivo de derrubar os regimes autoritários e, dessa forma, permitir que esses estados possam ser reinseridos na história. É isso que teria ocorrido no Iraque, segundo Ajami, após a ação norte-americana, apesar dos retrocessos pontuais próprios de povos ainda não acostumados a processos democráticos:

" The ballot is not infallible, and in Palestine we have now seen it reflect the atavisms of that society and the revolt against bandits and pretenders who had draped their predatory ways in the garb of secularism. But we can't hide behind "anthropology" and moral and political relativism. We can no longer claim that this is Araby, self- contained and immutable, under an eternal sky. We have rolled history's dice in the region, challenged its stagnant ways" (Ajami, 2006). 
Mais do que agir para a derrubada de regimes autoritários, Ajami acredita que é papel dos Estados Unidos atuarem como condutores de um amplo processo reformista com o objetivo de modernizar todo o mundo árabe, cujas tradições políticas e econômicas e cuja cultura teriam levado esses povos a uma situação crítica, da qual o fundamentalismo constituiria apenas um dos elementos (Ajami, 2003).

Breve consideração acerca do olhar eurocêntrico contemporâneo sobre as sociedades árabes e muçulmanas

Entre os atuais estudos sobre autoritarismo e democratização no mundo árabe-muçulmano, os discursos eurocêntricos são a base analítica para parte dos autores que trabalham a partir de uma perspectiva centrada na cultura política. Como mostram Brynen, Korany e Noble (1995: 6), podem ser identificadas três posições quanto à centralidade da cultura política para a compreensão desses processos. Uma primeira posição é a de que a análise cultural deve ser situada histórica e socialmente e que, em qualquer análise, deve-se observar o dinamismo e as disputas em torno da cultura, uma vez que essa não é fixa - autores como John Esposito (ver 1995 e 1996), Michael Hudson (ver 1995) e Fred Halliday (ver 1995 e 2003) seriam importantes representantes dessa abordagem. Uma segunda postura é a de que a cultura política não seria uma variável importante: ela seria uma variável dependente da própria política. Esses autores entenderiam que o uso da cultura como elemento exaustivo para a análise, além de apresentar dificuldades metodológicas (variações de atitudes, fraqueza e escassez dos dados etc.), restringiria o valor da análise das dinâmicas sociais e políticas dessas sociedades talvez o argumento mais conhecido, nesse sentido, seja o de Anderson (1995). Uma terceira corrente, a mais próxima do que estamos descrevendo como eurocentrismo, destaca a incompatibilidade ou tensão entre a cultura árabe e/ou islâmica e a democracia. Os autores aqui analisados são importantes representantes desta posição. Além do Islã, outros trabalhos apontam como impeditivos à democratização a intolerância e falta de confiança com relação aos que não fazem parte de um círculo próximo (geralmente descrito como a tribo ou o clã), a propensão à aceitação de teorias conspiratórias pelas sociedades 
muçulmanas (Pipes, 1996; Entelis, 1989; Ajami, 1981), o patriarcalismo próprio à família árabe (Sharabi, 1988) e o patrimonialismo, como fenômeno a-histórico (Bill e Springbord, 1990).

Entre os fatores apontados pelos autores internalistas como bloqueios à modernização dessas sociedades, o Islã é o mais importante. A idéia geral é que o Islã seria um fator imprescindível para o entendimento das sociedades em que ele é a principal fé, sendo o responsável por levá-las a tomar um rumo diferente das outras (Demant, 2004: 335). Caso se queira entender essas sociedades, seria necessário compreender-se como os preceitos básicos do Islã impactaram em seu desenvolvimento histórico - sobretudo em suas relações com o Ocidente - e como hoje ele pesa sobre as formas como essas sociedades se organizam política e economicamente.

Deve-se observar que o pressuposto implícito à análise desses autores, como buscamos demonstrar, é que o Islã é um elemento imutável, tanto no espaço quanto no tempo. A explicação para a dinâmica das sociedades muçulmanas atuais poderia, dessa forma ser buscada, em grande medida, no Corão ou no modelo político e social da comunidade em que viveu o Profeta ou no califado. O Islã é visto, aqui, de forma a-histórica: boa parte dos argumentos desses autores aceita a idéia de que as instituições muçulmanas já estavam pré-figuradas nas práticas do Profeta, sem que se atenha ao fato de que se produziram, ao longo da história, sistemas políticos diferentes, em grande parte devido a desenvolvimentos internos às instituições políticas islâmicas e à interação dessas instituições com diferentes condições históricas e culturais (Sabra, 2003). Isso permite que o Islã seja fixado como um dado, a partir do qual os outros fatores se articulariam. Como destacava Said especificamente sobre a obra de Lewis:

"According to Lewis, Islam does not develop, and neither do Muslims; they merely are, and they are to be watched, on account of that pure essence of theirs (according to Lewis), which happens to include a long-standing hatred of Christians and Jews... The core of Lewis's ideology about Islam is that it never changes, and his whole mission is now to inform conservative segments of the Jewish reading public, and anyone else who cares to listen, that any political, historical 
and scholarly account of Muslims must begin and end with the fact that Muslims are Muslims" (Said, 2003: 317-318).

Atribuir tal papel ao Islã na explicação das sociedades em que ele é a crença majoritária permite que a fraqueza das instituições democráticas ou 0 fundamentalismo muçulmano sejam entendidos como conseqüência de uma fé que continua a governar a mente de seus aderentes, apenas esperando as condições históricas para que ela possa ressurgir em seu formato puro, tradicional, como forma de organização do social e do político (Lockman, 2005: 65).

Esposito observa que esse enquadramento teórico e ideológico, ou seja, a idéia de que existe um Islã monolítico, permite que conflitos complexos e bastante diferentes entre si - como os do Sudão, Líbano ou da Bósnia - sejam analisados sem que se dê especial atenção aos fatores políticos e socioeconômicos a eles subjacentes, uma vez que eles são descritos basicamente em termos culturais, sobretudo religiosos (Esposito, 1995: 204). Essa compreensão do papel da cultura no desenvolvimento histórico das sociedades, aqui chamada de "internalismo culturalista", é dotada de um pressuposto essencialista fundamental; um essencialismo que assume uma inércia civilizacional de séculos, uma "estática" social, em oposição a uma pretensa "dinâmica ocidental". A cultura é um "dado", a que se conforma a política e, no limite, toda a possibilidade de agência coletiva e de contestação.

Neste ponto, a observação de Barrington Moore acerca do papel da cultura na compreensão de disputas políticas e dinâmicas sociais parece um contraponto bastante pertinente:

"Culture or tradition is not something that exists outside of or independently of individual human beings living together in society. Cultural values do not descend from heaven to influence the course of history. To explain behavior in terms of cultural values is to engage in circular reasoning. The assumption of inertia, that cultural and social continuity do not require explanation, obliterates the fact that both have to be recreated anew in each generation, often with great pain and suffering. To maintain and transmit a value system, humans beings are punched, bullied, sent to jail, thrown into 
concentration camps, cajoled, made into heroes, encouraged to read newspapers, stood up against a wall and shot, and sometimes even taught sociology. To speak of cultural inertia is to overlook the concrete interests and privileges that are served by indoctrination, education, and the entire complicated process of transmitting culture from one generation to the next" (Moore, 1967: 486).

A essencialização da cultura como ponto de partida da análise dessas sociedades traz graves conseqüências quando do tratamento da questão do "impacto da modernidade ocidental" sobre elas, em especial no que se refere à democracia secular. Para Lewis e Ajami, por exemplo, o Islã tem em si implícita a não separação entre igreja e estado - o Islã seria din wa dawla (Fé e Estado), de acordo com seus preceitos originais. A aceitação da democracia aos moldes ocidentais exigiria uma revisão desses preceitos - ou, como afirma Lewis, os muçulmanos devem buscar o "remédio Cristão" para o mal próprio dessa não separação entre igreja e estado (Lewis, 1996: 61). O Islã, em sua forma original e até hoje praticado, deveria ser considerado uma barreira aos avanços democráticos no mundo muçulmano, uma vez que seria intrínseco a ele uma oposição à modernidade. Aos povos do Oriente Médio restaria, então, uma escolha entre um projeto modernista reformador - aos moldes daquele liderado na Turquia por Kemal Ataturk - e um outro modelo que atribui todo o mal ao abandono da herança histórica do Islã (Sabra, 2003). Os grupos islamistas, por sua vez, seriam uma resistência natural ao avanço da democracia nessas sociedades, uma vez que pregam a aplicação de um Islã puro como forma de organização social, o que impediria o desenvolvimento de uma instituição baseada na soberania popular. Mais do que isso, como afirma Sabra, tais movimentos em geral são vistos, pelos internalistas, como a forma final de uma série de ideologias totalitárias a dominar o Oriente Médio, facilmente plantadas no terreno fértil da teocracia islâmica (Sabra, 2003).

Um outro elemento fundamental desse tipo de apropriação do discurso eurocêntrico, aqui em análise, é o já mencionado "internalismo" de traço culturalista. Há um consenso entre os autores dessa "escola": as sociedades árabes e muçulmanas estariam passando por uma grande crise, da qual o fundamentalismo e a persistência do autoritarismo seriam os principais elementos. Ao mesmo tempo, 
esses autores dão respostas bastante inflexíveis para a questão sobre o papel exercido pelo Ocidente para a configuração histórica dessa crise: se há "culpados"37 por esse processo, eles são as sociedades atingidas por esses males, e não o Ocidente ou qualquer estado que pertença a ele. Isso, de certa forma, já é evidente na própria idéia de que alguns autores possam ser classificados como internalistas. Contudo, a forma categórica como essa questão é colocada por esses autores faz ecoar mensagens bastante contundentes sobre a forma como o Ocidente deve se colocar para resolver os problemas do Oriente Médio e sobre como as próprias populações dessa região devem assumir o fardo da culpa por uma crise gerada internamente.

Mais uma vez, esse tipo de análise internalista sofre de uma simplificação que não se pode justificar em termos de um esforço de parcimônia explicativa: essa simplificação leva a que importante parte da explicação histórica seja obscurecida. Como qualquer região do globo - e, em especial, do Terceiro Mundo - o Oriente Médio não pode ser entendido sem que se leve em conta os padrões de interação entre ele e outras regiões do mundo, em especial as dinâmicas políticas, econômicas, sociais e culturais entre a região e as grandes potências ${ }^{38}$. Como observa Halliday, por exemplo, pode ser dado destaque a dois processos históricos nos quais o Oriente Médio esteve inserido e cujas conseqüências para as sociedades/estados da região foram, em graus diferentes, marcantes: 1) O Oriente Médio foi, por um longo período, sujeito à dominação do mundo capitalista, seja por meio de colonialismo ou de controle indireto, com grandes conseqüências tanto para a formação dessas sociedades como para a própria definição das fronteiras entre os estados, que não representa divisões estabelecidos em um passado distante, mas, sim, as decisões de administradores coloniais; 2) A Guerra Fria, da qual a região constituiu uma das mais importantes arenas de disputa (Halliday, 2003, 27-30) ${ }^{39}$.

37 Já de início, vale a pena observar como uma análise histórica ou sociológica cientificamente fundamentada parte de um ponto equivocado ao organizar explicações em termos da busca de "culpados", em vez de centrar-se na reconstrução e explicação de processos históricos.

${ }^{38}$ Trataremos deste tema de forma mais aprofundada no próximo capítulo.

39 Uma ampla análise das conseqüências da Guerra Fria para as dinâmicas internas aos estados e para as dinâmicas regionais no Oriente Médio - partindo-se, a dizer, do pressuposto de que a região não deve ser entendida como um todo monolítico, mas sim levando-se em conta as especificidades nacionais e subregionais - pode ser encontrada em Shlaim e Sayigh (1997). 
Ainda segundo Halliday:

\begin{abstract}
"The contemporary Middle East cannot be understood apart from the historical experience it underwent in the colonial era, the character of its economic links to the developed countries, and the impact upon it prolonged Soviet-American rivalry. But while these international factors provide a context and often a catalyst, it is equally important to locate the conflicts of the region in their specific, local origins and to develop judgements and political assessments also based on these particular factors. It is, indeed, in the tension between these two approaches that the specific difficulty of analyzing the Middle East lies" (Halliday, 2003: 22).
\end{abstract}

Estas questões levantadas por Halliday nos levam a questionamentos centrais sobre a possibilidade da análise de processos de modernização e de dimensões da modernidade, particularmente em sociedades periféricas, sem uma consideração sobre as formas como essa se relaciona com as demais sociedades, em especial as ocidentais. Trata-se, a primeira vista, de um problema de recorte de objeto; contudo, creio que as considerações desenvolvidas até o momento convidam para uma reconsideração dessas questões como referentes ao próprio nível de análise e à ontologia do social a partir da qual as questões e teorias sobre a modernidade são formuladas. O ponto central, como se tentará mostrar nos capítulos seguintes, é se definir a partir de que ponto de vista se pode elaborar um discurso crítico sobre a modernidade - e quais as possíveis conseqüências de se assumir um ponto de vista que não o eurocêntrico.

\title{
Discursos eurocêntricos e o desafio do moderno no Brasil
}

O pensamento social no Brasil, no que tem de mais essencial, gravita em torno do problema da constituição da modernidade brasileira. Desde a obra de intervenção de um político do Império como Tavares Bastos até a mais recente produção acadêmica, nossos diversos "intérpretes" (se é que esse termo possa ser usado para toda essa produção, sem as devidas ressalvas) esforçaram-se, acima 
de tudo, para fazer sentido sobre a constituição da modernidade em uma sociedade tão notavelmente "não-clássica" como esta.

Sérgio Buarque de Holanda, no seminal Raízes do Brasil, aponta que somos uma nação que já nasce marcada por uma dificílima empreitada: "A tentativa de implantação da cultura européia em extenso território, dotado de condições naturais, se não adversas, largamente estranhas à sua tradição milenar é, nas origens da sociedade brasileira, o fato dominante e mais rico de conseqüências" (Holanda, 2006 [1936]: 31). Logo à frente, Sérgio Buarque já levanta um condicionante que traria ainda mais dificuldades ao quadro geral: aquela tentativa de implantação de uma cultura européia teria como realizadores, nestas terras, uma nação das "menos européias" do Velho Continente: teríamos recebido nossa herança de uma nação ibérica (Holanda, 2006: 31). Esse fato é igualmente central para um outro grande intérprete, como Raymundo Faoro: a sua clássica análise sobre o estamento burocrático brasileiro (os verdadeiros "donos do poder" na história do país) inicia-se com uma abordagem sobre as origens do estado português - estado em que, diferentemente do que teria se dado com seus "clássicos" congêneres europeus, "o feudalismo cedeu lugar, ainda mal assentado, a poder maior, centralizador e de natureza militar" (Faoro, 1958: 3).

$\mathrm{Na}$ verdade, a questão sobre a constituição da modernidade no Brasil se desdobrou em diversas outras, mobilizadas conforme as diferentes posturas analíticas e preocupações dos diversos intérpretes. Três desses desdobramentos parecem-me centrais: o primeiro refere-se aos entraves à modernização presentes no Brasil ao longo de sua história; o segundo é o questionamento sobre as vias de acesso ao moderno; o terceiro, por fim, gira em torno da natureza da modernidade brasileira $^{40}$. Irei me concentrar, neste capítulo, no primeiro desses desdobramentos. O objetivo é mostrar como a idéia de "obstáculo" é marcante também em nosso pensamento social, tendo sido elaborada, de forma mais influente e sofisticada, nas

40 Tavolaro (2005) mostra a centralidade deste terceiro desdobramento, tentando igualmente desenvolver uma abordagem própria, partindo da idéia inicial de "múltiplas modernidades". Apesar de oferecer alguns pontos de partida originais e bastante ricos, perece-me que Tavolaro erra ao igualar a tradição sociológica da herança patriarcalpatrimonial à sociologia da dependência, afirmando que em ambas haveria um "essencialismo" que impediria que se analisasse a sociedade brasileira contemporânea e as sociedades centrais em "pé de igualdade". Apesar de concordar que a primeira dessas tradições fornece espaço para uma leitura essencialista (como se abordará mais à frente), não me parece que a sociologia da dependência, nitidamente orientada para uma consideração das dinâmicas globais da constituição da modernidade em contextos específicos, dê margem a esse tipo de interpretação. 
obras de dois de nossos maiores "demiurgos": Sérgio Buarque de Holanda (Raízes do Brasil) e Raymundo Faoro (Os Donos do Poder). A meu ver, esses dois clássicos - certamente fundamentais para a compreensão de nossa história e marcados por uma erudição e uma capacidade de síntese próprias a nossas mais importantes realizações intelectuais - são os exemplares maiores de duas "linhagens" ${ }^{\text {"41 }}$ no pensamento social brasileiro. Cada uma destas é centrada em um dos elementos categoriais da estrutura de atitudes e referências eurocêntricas já descrita: a abordagem sobre a conduta de vida e sobre o caráter despótico do poder, respectivamente. Tratando-as como obras fundamentais dessas duas linhagens, abre-se espaço para a reflexão sobre como ambas embasam-se em formulações e idéias anteriores e sobre como ainda são fontes de inspiração e diálogo nas atuais reflexões intelectuais, políticas e culturais sobre o país.

Dito de outra maneira, Holanda e Faoro são, no Brasil, representantes maiores daquele domínio analítico - bastante influente em interpretações sobre o desenvolvimento histórico da sociedade brasileira - que lança mão de categorias e "formas de pensar" derivadas de um discurso sociológico eurocêntrico para a compreensão da história desta sociedade, sendo as noções de "entrave" ou "obstáculo" e a descrição da imutabilidade histórica os articuladores dessa maneira de analisar esse processo histórico. O uso central dessa idéia fornece a chave lógica para a construção de uma "história imóvel" - este, como vimos, outra temática fundamental na estrutura categorial e lógica eurocêntrica. Essa constatação abre a possibilidade, por fim, do uso teórico da crítica ao eurocentrismo para a análise dessa literatura e das categorias por ela mobilizadas.

Werneck Vianna (1999) já observou que a absorção da obra de Weber no pensamento social brasileiro deu-se principalmente a partir da "perspectiva do atraso", tendo-se lançado mão, em especial, de suas categorias desenvolvidas para a análise do Oriente - sobretudo, o tema do patrimonialismo. Souza (1998 e 2000), tratando da tradição sociológica por ele denominada "sociologia da inautenticidade", amplia aquela reflexão de Werneck Vianna, buscando mostrar o impacto da idéia de que o Brasil seria um reflexo do colonizador português, tendo supostamente carregado ao longo de seu processo histórico todos os "vícios" originais daquele,

\footnotetext{
${ }^{41}$ Utilizo aqui o termo de forma pouco precisa, mas buscarei mostrar como outras obras importantes das Ciências Sociais brasileiras compartilham de diversos dos pressupostos, categorias e das formas de pensar presentes nesses trabalhos. Para a idéia de "linhagens" de pensamento, me baseio em Brandão (2007).
} 
sobretudo o personalismo e o patrimonialismo. Essas abordagens serviram como pontos de partida para a reflexão que aqui será desenvolvida, tentando-se avançar na análise da influência dos discursos eurocêntricos sobre nosso pensamento social e as limitações inerentes a esse discurso. Aqui, não se trata, portanto, apenas de uma avaliação do uso de categorias utilizadas pelos clássicos europeus para a compreensão das sociedades não-ocidentais: além destas, é preciso observar temáticas e técnicas de representação recorrentes em alguns textos chave do pensamento social brasileiro que encaminharam uma comparação entre o desenvolvimento histórico brasileiro e o das sociedades tidas como centrais, e as maneiras pelas quais o processo histórico do Brasil pôde ser descrito como anormal, patológico, incompleto. Isso permitirá, de forma paralela à exposição realizada com relação aos autores que tratam das sociedades árabes $\mathrm{e}$ muçulmanas, avaliar as dimensões e os reais impactos teóricos e políticos das formas do pensar eurocêntrico.

Antes disso, é preciso observar que as obras desses clássicos e a influência por elas exercida na produção posterior nas ciências sociais, apesar de sua enorme importância, não esgotam o impacto social dessas formas de fazermos sentido de nossa realidade. Apesar de apresentarem críticas distintas das que serão aqui desenvolvidas, Jessé Souza e Luiz Werneck Vianna tratam essa produção como, respectivamente, "a interpretação dominante e mais influente sobre a singularidade cultural brasileira" (Souza, 2000: 159) e (ao menos com relação aos trabalhos derivados da análise de Faoro) "a versão hoje hegemônica nas ciências sociais e na opinião pública sobre a interpretação do Brasil” (Werneck Vianna, 1999: 35).

Como observa Brandão (2005: 234), os clássicos de nossas ciências sociais "continuam a ser lidos como testemunhas do passado e como fontes de problemas, conceitos, hipóteses e argumentos para a investigação científica do presente". Mas, além disso, esses clássicos são constituídos a partir de visões socialmente disseminadas sobre nós mesmos e, depois de imprimirem a sua marca pessoal a esse arcabouço social, fornecem uma nova potência a essas auto-imagens, ainda que elas tenham sido ressignificadas. Nesse sentido, essas "formas de pensar" inserem-se em uma dinâmica social de longa duração, potencializando ou 
matizando conflitos sociais e fornecendo estruturas cognitivas orientadoras da práxis política e social ${ }^{42}$.

\section{A tradição do Despotismo Oriental e "Os Donos do Poder"}

No pensamento social brasileiro, a tradição do despotismo oriental encontra a maior expressão na obra de Raymundo Faoro. A sua grande obra, Os donos do poder - cuja primeira edição, publicada em 1958, não obteve grande reconhecimento - tornou-se, a partir de sua segunda edição, de 1975, uma das mais importantes e influentes interpretações sobre a história do Brasil. Seu impacto sobre a produção acadêmica é amplamente notado na literatura recente. Entre as principais obras que dão continuidade ao legado teórico de Faoro, destacam-se $O$ Minotauro Imperial (1978), de Fernando Uricoechea, e Bases do Autoritarismo Brasileiro (1982), de Simon Schwartzman (ver Campante, 2003; Werneck Vianna, 1999; Souza, 1998).

Como reivindica o próprio autor, essa obra é a grande introdutora em nossa literatura da "análise do Estado brasileiro sob o prisma do patrimonialismo" (Faoro, 1993: 18). O mote central do livro é a demonstração de que a chave interpretativa fundamental para a compreensão de nossa história é o "patrimonialismo estamental", ou seja, o domínio do aparato estatal centralizado por um estamento que se colocaria acima de toda a sociedade, impedindo sua livre expressão e seu desenvolvimento autônomo.

Esse tipo de dominação política derivaria, segundo Faoro, da continuidade, na colônia, da forma de organização do aparato de poder fundado na metrópole. Não seria uma simples coincidência o nosso tipo de estrutura social e o fato de termos sido colonizados por portugueses: aquele seria uma derivação inequívoca deste. Portugal teria sofrido um processo de centralização precoce, quando comparado aos outros estados europeus. O Estado português, criado sob o signo da guerra, teria como elementos centrais a predominância do Rei e o tesouro do príncipe desde o século XIV. Esse domínio patrimonial inicial teria dado lugar, nos

\footnotetext{
${ }^{42}$ As epígrafes com que se inicia este capítulo, formuladas em contextos específicos e tratando de sociedades periféricas diferentes, parecem exemplificar bastante claramente essa dinâmica.
} 
séculos seguintes, (sobretudo com a instalação de uma economia monetária e com o início dos empreendimentos comerciais marítimos) a um patrimonialismo estamental, sob domínio de um grupo, na medida em que "o quadro administrativo estereotipifica-se, ganha cartilagens e, de mera reunião de cortesãos e protegidos, faz-se órgão de domínio" (Faoro, 1958: 12). Aí estaria a fundação de uma nova época, cuja estrutura, afirma Faoro, "ainda hoje perdura" (Faoro, 1958: 4).

Depois de formada essa estrutura original, ela seria transposta por completo à colônia, transmitindo a mácula desse pecado original:

"A administração metropolitana, apressada e sôfrega em recolher tributos e quintos, instala-se com grandes tentáculos, na colônia. As peças do Estado português atravessam o oceano, firmando-se no litoral e nos sertões. Despreza-se a realidade americana, as peculiaridades locais são esmagadas: a disciplina da ordem pública portuguesa, prestigiada pelos batalhões, foi transplantada, como carapaça fabricada sem as medidas do corpo. O Estado sobrepõe-se à sociedade, amputando todos os membros desta que não pudessem ser dominados" (Faoro, 1958: 78).

Assim, "Repete-se, na América, a história de Portugal” (Faoro, 1958: 79). E essa história é repleta de obstáculos ao desenvolvimento do capitalismo racional, uma vez a economia cresce sob a tutela do Estado, cujos interesses coadunavam com o comércio urbano, mas não com qualquer tipo de indústria autônoma.

Como observa Werneck Vianna, Faoro avizinha o "iberismo" do despotismo oriental (Werneck Vianna, 1999: 35). Para Faoro, raciocinando de forma liberal clássica, mas também em consonância com os principais elementos da tradição eurocêntrica, essa presença "minotáurica" do Estado é um entrave ao desenvolvimento da livre iniciativa e da empresa lucrativa particular - ou seja, do próprio capitalismo racional. Esse só poderia passar a existir se essa forma de dominação patrimonial fosse rompida, ensejando-se a criação de um livre mercado; com isso, "as classes expulsariam os estamentos" (Faoro, 1958: 26). Daqui, depreende-se um dos reflexos mais notáveis da tradição eurocêntrica no pensamento de Faoro: nossa sociedade é descrita como destituída, desde sua criação, de qualquer grupo que se contrapusesse ao Estado e ao seu estamento 
dominante. Este seria o "portador" absoluto de toda nossa forma de ser. A única clivagem relevante é aquela entre estamento burocrático e o restante da sociedade, incluindo-se nesse resto, como observa Campante, camadas proprietárias ou não (Campante, 2003: 154). O estamento é a "estratificação dominante, detentora do monopólio dos poderes de direção e de mando do Estado. Exerce sobre o povo o influxo de modelo social, de padrão ético" (Faoro, 1958: 43). Com a plena centralização, concretizada no segundo Reinado, não restaria, então, qualquer dúvida: "O Estado era tudo, e a nação quase nada" (Faoro, 1958: 193). Nada que nos diferencie, portanto, das "sociedades asiáticas" descritas na tradição do despotismo oriental.

Quanto a este aspecto, é notável a semelhança entre o raciocínio de Faoro e a descrição de Weber sobre a sociedade chinesa e o papel dos "literati" - estamento burocrático portador da ética confuciana e que, por mais de 2000 anos, teria sido o estamento dominante daquela sociedade (Weber, 1951: capítulo V). Como aponta Love, o pressuposto orientador da análise de Weber sobre a China é que, uma vez estabelecida essa configuração sócio-política básica - um tipo clássico de "burocracia patrimonial" - ela se tornou um elemento quase "imutável" na história chinesa (Love, 2000: 176) ${ }^{43}$. Isso não passa despercebido ao próprio Faoro que, influenciado pela obra do sociólogo alemão, nota a adequação de uma "ética confuciana" como fundamento de conduta do estamento burocrático e a "sensível incompatibilidade entre seu espírito e o espírito do capitalismo" (Faoro, 1958: 268). Essa ética confuciana, cujo portador é o próprio estamento, seria outro grande obstáculo à racionalização de nossa conduta de vida.

O atraso brasileiro, portanto, é descrito como a conseqüência da permanente herança estatal portuguesa, que aqui teria impresso um padrão "oriental" de relações entre estado e sociedade. Este aspecto do raciocínio de Faoro e de Holanda, a dizer, a transposição de padrões culturais, de sociabilidade e instituições de Portugal ao Brasil, como se aqui não tivesse havido a necessidade da adaptação desses às novas condições históricas, é o principal alvo da crítica de Souza: "na perspectiva dos autores analisados [Sérgio Buarque de Holanda, Raymundo Faoro e Roberto DaMatta], a problemática valorativa é percebida como se influência e a

\footnotetext{
${ }^{43} \mathrm{Na}$ descrição de Faoro, qualquer ameaça ao domínio centralizador do Estado sempre foi vítima de enorme fracasso, como o que teria se dado, por exemplo, com a ocasião do Código de Processo e do Ato Adicional, durante a Regência (Faoro, 1958: 162).
} 
transferência de valores culturais transpusessem oceanos (no caso não só de água mas de dessemelhanças também), como quem leva a roupa do corpo" (Souza, 2000: 206; destaque no original).

Faoro se enquadraria, assim, em uma tradição "americanista", que enxerga o atraso social do Brasil como decorrente da persistência da herança ibérica. $O$ iberismo seria visto como um elemento de determinação estrutural e constituiria para os americanistas, "um caminho natural de obscurantismo, autoritarismo e burocratismo para a vida pública e social" (Werneck Vianna, 1997: 153). Werneck Vianna aponta ainda que Tavares Bastos - precursor da "linhagem" do pensamento político em que se enquadraria Faoro (conforme Brandão, 2005 e 2007) - já utiliza, em sua descrição do Estado Imperial centralizador, qualificações do gênero "nós e o despotismo chinês", "novo espírito chinês" e "sistema chinês" (Werneck Vianna, 1997: 167).

Fiquemos então, muito brevemente, com Tavares Bastos. Ele é provavelmente, ao lado de Faoro, o grande formulador de uma visão do Brasil informada por preceitos liberais. Este político do Império, em obras como $A$ Província (1870) e Os males do presente e as esperanças do futuro (1939) desenvolve um verdadeiro programa para o país, bastante informado pela tradição liberal em circulação na Europa e, em grande medida, influenciado pela observação das instituições políticas norte-americanas. Os "males" a serem combatidos sobretudo derivados da centralização do Império - são algo muito próximo ao que a tradição eurocêntrica descreveu como o despotismo oriental. Tavares Bastos é bastante explícito quanto a isto: "Queremos, sem dúvida, reformas constitucionais. Só nas estagnadas sociedades da Ásia são invioláveis as instituições e os povos" (Bastos, 1939: 10). A centralização política brasileira é, em inúmeros momentos, comparada aos impérios orientais estáticos: a capital brasileira, “...como Bizâncio, projeta ao longe a sombra do seu negrume" (Bastos, 1939: 28).

Tavares Bastos também observa que "o absolutismo brasileiro" deriva-se, em grande medida, da herança portuguesa. O raciocínio aqui, apesar de pouco desenvolvido, assemelha-se bastante àquele que será desenvolvido por Faoro, um século depois: Tavares Bastos aponta como Portugal teria "brilhado" no século XV, 
à frente dos outros povos, para depois "morrer para sempre": "a historia interna da metropole aclara a physionomia da colônia". (Bastos, 1939: 29) ${ }^{44}$.

A análise de Werneck Vianna - que tomamos emprestada, mais uma vez parece bastante precisa: para Tavares Bastos, a singularidade da formação brasileira é observada a partir da configuração de seu sistema político; dessa forma, ele inaugura uma tradição de análise que passa por Raymundo Faoro e, mais recentemente, por Simon Schwartzman (Werneck Vianna, 1997: 169; ver Schwartzman, 1982).

Voltemos a Faoro. Em trabalho posterior a Os Donos do Poder, Faoro descreveu o patrimonialismo como uma forma de dominação variável ao longo de um espectro,

"um arco que vai desde o 'despotismo oriental', como as sociedades hidráulicas descritas por Karl A. Wittfogel (Despotismo Oriental, 1966) totalmente alheias ao capitalismo e com ele talvez incompatíveis, até o estado patrimonial oculto no capitalismo, criando o 'capitalismo politicamente orientado', que controla, fomenta, estimula e faz da economia um apêndice de poder público" (Faoro, 1993: 17).

\section{A "especificidade" do desenvolvimento de Portugal é repetidamente} contrastada por Faoro com um processo ideal de desenvolvimento, que teria se dado nas sociedades européias clássicas e, em especial, nos Estados Unidos. Nesse ideal de desdobramento histórico, a sociedade é que forma o Estado, e não o contrário, como se teria dado em Portugal e, por transposição, no Brasil. Com a

\footnotetext{
${ }^{44}$ Uma diferença fundamental deve ser apontada entre Tavares Bastos e Raymundo Faoro: este, em seus principais textos, procura mostrar as possibilidades reais de um projeto de descentralização e de reforma das instituições brasileiras - algo que inexiste em Faoro, tanto em sua grande obra quanto em textos posteriores. Como aponta Werneck Vianna, para Tavares Bastos, grande parte do iberismo brasileiro não se localizaria na sociedade civil do mundo agrário, mas no "Estado asiático" - ou seja, para o liberal do Império, a sociologia deriva da política (Werneck Vianna, 1997: 162). Ricupero e Ferreira sugerem que, se o estado é a síntese da opressão em Os donos do poder, a nação (apesar de não ser considerada com maiores cuidados) não ofereceria alternativas muito melhores aos destinos históricos do país (ver Ricupero e Ferreira, 2005). Esse seria o principal motivo do caráter trágico da obra de Faoro - e mesmo de seus diagnósticos políticos elaborados quatro décadas depois da primeira edição de sua grande obra (para uma análise das reflexões e intervenções públicas de Faoro ao longo da década de 1990, ver Mendonça, 1999).
} 
presença inquebrantável desse estamento (durante ao menos cinco séculos), a "racionalização da vida" não pôde se desenvolver. Essa regulação da economia pelo estamento "fortalece o comércio, mas dificulta e impede a empresa racional, suporte onde assentaria a atividade industrial, que, no século $X V$, se difundiu largamente na Europa, com exceção da Península Ibérica" (Faoro, 1958: 28). Como se vê, Faoro lança mão da duplicação da narrativa comum ao discurso eurocêntrico: o desenvolvimento histórico brasileiro, repleto de entraves, é descrito como variação patológica do modelo padrão: "O estudo da colonização brasileira não pode ser desenvolvido pelo símile das colônias inglesas da América do Norte. Lá prevaleceu, efetivamente, a iniciativa particular sem nenhuma sombra de agenciamento e regulação estatais" (Faoro, 1958: 53). Em contraposição e desvantagem com relação a esse capitalismo racional da livre empresa, o capitalismo seria "politicamente orientado" - "uma modalidade patológica de acesso ao moderno, implicando uma modernização sem prévia ruptura com o passado patrimonial" (Werneck Vianna, 1999: 36).

Dada essa patologia original, dirá Faoro posteriormente, no Brasil, como buscarei examinar em mais detalhes logo à frente, a história é imóvel:

\begin{abstract}
"A história, por não ter o país uma sociedade civil viva, estruturada e atuante, desenvolve-se em decorrência dos impulsos ditados pelo poder público. Em conseqüência, em lugar de projetar um desenvolvimento que se expande para o futuro, triturando o passado, superando-o em novas manifestações, a história é recorrente, repetitiva. Não temos um processo histórico, mas uma sucessão temporal, com retornos de formas e de tempos que não passam de um recondicionamento de outro tempo" (Faoro, 1993: 17-18).
\end{abstract}

Conduta de vida metódica e a linhagem de "Raízes do Brasil"

Raízes do Brasil é uma obra seminal para a fixação de uma determinada forma de se compreender o Brasil. Na verdade, de uma série de formas: são inúmeras as análises da obra, apontando possibilidades bastante diversas de 
interpretação ${ }^{45}$. Certamente, trata-se de uma brilhante obra de "invenção do Brasil" (Cardoso, 1993), mas que, na verdade, aponta para diversos Brasis diferentes - e, talvez, essa seja uma das maiores riquezas desse genial ensaio. Ela é bastante aberta, muitas vezes ambígua, servindo realmente a essa diversidade de leituras. Isso se deve, sobretudo, à forma como o autor entendia o momento histórico em que o livro era escrito - vivia-se, a seu ver, um momento de ruptura do devir histórico (Dias, 2002: 905); "estaríamos vivendo assim entre dois mundos: um definitivamente morto e outro que luta por vir à luz" (Holanda, 2006: 180).

Nesse contexto, parece-me que o objetivo geral da obra é bem captado pela importante leitura de Avelino Filho: o livro pode ser lido como "a identificação dos obstáculos que entravam a modernização política e econômica do país; como as raízes daquilo que deve ser enfrentado para a criação de uma nova sociedade, de uma nova cultura política, que ao mesmo rompa com o bacharelismo e outros mecanismos sedimentados e liberte a verdadeira expressão do nacional" (Avelino Filho, 1987: 36-37). Essa descrição dos objetivos da obra carrega em si a complexidade da tarefa que Sérgio Buarque enfrenta: ao mesmo tempo em que as raízes têm de ser destruídas para permitir a ascensão da modernidade entre nós, a passagem para esse novo mundo não pode se basear em códigos importados das ditas sociedades modernas; o processo de absorção do moderno deve ser "antropofágico". O uso do termo é proposital: Sérgio Buarque sofre profunda influência das discussões modernistas da década anterior ao livro, o que me parece central para se compreender a maneira como ele, em linhas bastante gerais, vislumbra a forma de realização do "americanismo" entre nós (ver Avelino Filho, 1987 e Prado, 1998).

De qualquer forma, é difícil negar que a temática da destruição das raízes seja recorrente na obra. Nossas raízes são os verdadeiros obstáculos de nosso acesso ao moderno. Isso é captado pela leitura de Antonio Cândido (hoje, já ligada quase organicamente à obra): "E, do ponto de vista político, que sendo o nosso passado um obstáculo, a liquidação das 'raízes' era um imperativo do desenvolvimento histórico" (Cândido, 2006: 20).

${ }^{45}$ Uma boa revisão dessas interpretações encontra-se em Piva (1997). 
Quais seriam essas raízes? Elas seriam os padrões de sociabilidade que teríamos herdado de Portugal e que atravancariam a criação de uma ordem social moderna no país. Sérgio Buarque é bastante enfático:

"No caso brasileiro, a verdade, por menos sedutora que possa parecer a alguns dos nossos patriotas, é que ainda nos associa à Península lbérica, a Portugal especialmente, uma tradição longa e viva, bastante viva para nutrir, até hoje uma alma comum, a despeito de tudo quanto nos separa. Podemos dizer que de lá nos veio a forma atual da nossa cultura; o resto foi matéria que se sujeitou bem ou mal a esta forma" (Holanda, 2006: 40).

O traço central da conduta de vida ibérica e que a nós teria sido transferida é o personalismo. Esse traço seria específico da Península Ibérica, "uma característica que ela está longe de partilhar, pelo menos na mesma intensidade, com seus vizinhos do continente. É que nenhum desses vizinhos soube desenvolver a tal extremo essa cultura da personalidade, que parece constituir o traço mais decisivo na evolução da gente hispânica, desde tempos imemoriais" (Holanda, 2006: 32). Aqui, a duplicação do discurso já se revela ${ }^{46}$. Todo o desenvolvimento do raciocínio de Holanda girará em torno da comparação entre tipos dicotômicos de sociabilidade, baseando-se em um certo tipo ideal de conduta do homem moderno em muito baseado no modelo de homem puritano e de sua conduta de vida metódica. O trecho que segue ao anterior já carrega implicitamente essa comparação: "Pode-se dizer, realmente, que pela importância particular que atribuem ao valor próprio da pessoa humana, à autonomia de cada um dos homens em relação aos semelhantes no tempo e no espaço, devem os espanhóis e os portugueses muito de sua originalidade nacional" (Holanda, 2006: 32).

O ibérico é o anti-puritano: aproxima-se, na descrição de Holanda, ao confuciano, incapaz de orientar-se por laços impessoais ${ }^{47}$. Entre nós, haveria quase

${ }^{46}$ Esteves desenvolve com mais detalhes a ferramenta da "duplicação da narrativa" em Holanda (Esteves, 1998). Contudo, o autor não se refere a como esse mecanismo discursivo replica uma forma de construção da narrativa própria a uma tradição eurocêntrica.

47 Souza (1998) já indicou, a meu ver com extrema pertinência, a semelhança da comparação, realizada por Weber, entre a ética protestante e a confuciana, e aquela que 
uma "divinização da criatura", com sua correspondente aversão a relações sociais objetivas, impessoais. Esse traço cultural, o personalismo, exige que as relações diretas entre indivíduos sejam o princípio e o fim da ação social. Ações impessoais não encontrariam correspondência na estrutura cognitiva orientadora da conduta de vida desse homem ibérico "típico" (aqui, também em sentido weberiano). No contexto da colonização brasileira, esse personalismo inicial encontrará berço em uma estrutura rural patriarcal em que ele teria enorme espaço para florescer, desenvolvendo aí os fundamentos para sua "colonização" de toda a vida social:

\begin{abstract}
"A família patriarcal fornece, assim, o grande modelo por onde se hão de calcar, na vida política, as relações entre governantes e governados, entre monarcas e os súditos. Uma lei moral inflexível, superior a todos os cálculos e vontades dos homens, pode regular a boa harmonia do corpo social, e portanto deve ser rigorosamente respeitada e cumprida" (Holanda, 2006: 85).
\end{abstract}

O patriarcalismo, principalmente em sua versão patrimonialista, seria a forma política específica ao personalismo (Souza, 2000: 164).

O mesmo paralelo pode ser feito entre a valorização do trabalho da conduta de vida metódica puritana e o típico desprezo ibérico por ele, a nós transferido: "O trabalho manual e mecânico visa a um fim exterior ao homem, e pretende conseguir a perfeição de uma obra distinta dele. É compreensível, assim, que nunca se tenha naturalizado entre gente hispânica a moderna religião do trabalho e o apreço à atividade utilitária" (Holanda, 2006: 38).

A dicotomia entre "trabalho" e "aventura" também consumaria essa duplicação do discurso, recurso usado para representar o caráter deficitário da formação social brasileira com relação às sociedades modernas. A ética do trabalho não era parte da forma de ser social portuguesa: "o que o português vinha buscar era, sem dúvida, a riqueza, mas riqueza que custa ousadia, não riqueza que custa trabalho" (Holanda, 2006: 49). Esse tipo de conduta é descrito como bloqueador da própria inovação técnica, já que "nossos colonizadores eram, antes de tudo, homens

Sérgio Buarque desenvolve em Raízes do Brasil entre nossa conduta de vida tradicional (resumida no conceito de cordialidade) e a ética protestante. 
que sabiam repetir o que estava feito ou o que Ihes ensinara a rotina" (Holanda, 2006: 52-53).

O personalismo herdado de Portugal, aqui sintetizado com o domínio do patriarcado rural, teria gerado a "cordialidade". Essa pode ser vista como a síntese do padrão de conduta tradicional do brasileiro, gerada pela extensão do personalismo a todas as esferas do convívio social. Como afirma Souza (1998), o conceito de homem cordial sintetiza uma concepção de mundo social e de consciência individual, num quadro de referência recíproca. Em outros termos, estrutura da personalidade e estrutura social passariam a se nutrir reciprocamente.

O capítulo sobre a cordialidade, além de ser o mais influente, parece ser 0 ponto central de articulação do argumento de Sérgio Buarque sobre os obstáculos ao estabelecimento de uma ordem social moderna entre nós. O foco do capítulo são exatamente, como aponta Sallum Jr., as tensões entre as "formas tradicionais de sociabilidade, centradas na família patriarcal, e os padrões de sociabilidade inerentes ao mundo moderno" (Sallum Jr., 2006: 249). No padrão de conduta de vida captada pelo conceito de cordialidade, as relações pessoais, desenvolvidas, sobretudo, no seio da família, transbordam para a vida pública. A hipótese inicial que orienta a reflexão de Holanda é a idéia de que o Estado moderno nasceria pela transgressão da ordem familiar, e não pela ampliação desta. Só por meio dessa transgressão é que se poderia fundar uma ordem social "em que as instituições e as relações sociais, fundadas em princípios abstratos, tendem a substituir-se aos laços de afeto e de sangue" (Holanda, 2006: 143).

A "conduta de vida cordial" geraria estruturas políticas patológicas, uma vez que essas seriam frutos da institucionalização dos laços pessoais próprios da sociedade de homens cordiais. Essa ética, antítese da ética metódica impessoal moderna, permanece como entrave ao desenvolvimento de formas políticas modernas:

Com efeito, onde quer que prospere e assente em bases muito sólidas a idéia de família - e principalmente onde predomina a família de tipo patriarcal - tende a ser precária e a lutar contra fortes restrições a formação e a evolução da sociedade segundo conceitos atuais. A crise de adaptação dos indivíduos ao mecanismo social é, assim, especialmente 
sensível no nosso tempo devido ao decisivo triunfo de certas virtudes antifamiliares por excelência, como o são, sem dúvida, aquelas que repousam no espírito de iniciativa pessoal e na concorrência entre os cidadãos" (Holanda, 2006: 144; destaque no original).

Em uma sociedade de homens cordiais, resume o próprio autor, "Falta a tudo a ordenação impessoal que caracteriza a vida no Estado burocrático" (Holanda, 2006: 146). Assim, Holanda busca as causas do fracasso da instituição de uma ordem política moderna em traços específicos de nosso padrão de sociabilidade. Esse seria um reflexo político da cisão entre a visão de mundo ibérica (bem calçada em nossa estrutura social) e a cultura moderna, moldada pela Reforma Protestante e por revoluções científicas que teriam passado ao largo da Península lbérica (Avelino Filho, 1990: 7).

A cultura da cordialidade é descrita como motor de reafirmação do mesmo, de reiteração da tradição. Internamente, ela não poderia gerar os incentivos para a transformação da vida social - antes, ela deveria ser destruída para que se estabelecesse uma nova ordem social. Holanda consegue, contudo, captar em seu tempo as transformações que levariam à remoção desse obstáculo, sobretudo o crescente processo de urbanização por que o país estaria passando. Piva, em seu estudo da obra e do contexto social brasileiro em que ela foi criada, levanta uma importante advertência: apesar da valorização no novo em Raízes do Brasil, o livro parece descrever um Brasil dos anos 30 muito mais arcaico do que aquele que, de fato, existia. Esse anacronismo do livro, explica Piva, se dá pelo fato de que as "raízes" remetem-se às feições da elite que são alvos da crítica de Sérgio Buarque, elas mesmas anacrônicas face ao "Brasil real" (1997: xviii e xix). Parece-me, entretanto, que esse anacronismo também se deve à urgência com que Holanda via a necessidade de ruptura com aqueles obstáculos. As cores fortes visariam, pois, a destacar os traços negativos da ordem social brasileira, incompatíveis com uma ordem moderna, mais do que a estipular que a elite atrasada seria a destinatária única das mensagens formuladas por Sérgio Buarque.

Parece-me que há algo de correto nas análises de Avelino (1990) e Dias (2002) de que a cordialidade, em Raízes do Brasil, não pode ser vista como uma "essência" do brasileiro - embora essa tenha sido uma leitura comum desse conceito. Contudo, é inegável que Sérgio Buarque, assim como Faoro, desenvolve 
um argumento internalista e culturalista, tentando explicar nosso atraso como derivado de certas características internas à nossa sociedade (no caso, um padrão tradicional de conduta), características essas que, em alguns pontos da obra, parecem figurar como "resíduos explicativos" para a compreensão de nosso processo histórico. Esse é o ponto de partida estrutural de qualquer argumento eurocêntrico (ou de qualquer narrativa histórica que se apropria de uma estrutura de atitudes e referências eurocêntrica): trata-se da busca de traços internos às sociedades que permitam que se estabeleçam distinções entre seus processos de desenvolvimento, tendo por base a dicotomia Ocidente/não-Ocidente - o que descrevi anteriormente como internalismo culturalista. A isso se soma a evidente comparação entre as formas da sociabilidade brasileira e aquelas "próprias à modernidade". Assim, as causas do atraso desta sociedade poderiam ser buscadas internamente, essa busca correspondendo à própria análise dos entraves que impossibilitam nosso acesso ao moderno. As "sobrevivências arcaicas, que insistiam em confrontar-se com forças renovadoras do devir histórico" (Dias, 2002: 912) são sobrevivências de traços próprios das relações sociais e padrões de conduta e de racionalidade tradicionais estabelecidos no interior de nossa sociedade: o "externo" só é colocado como paralelo de comparação para a confirmação do atraso, não constituindo, ele mesmo, objeto de sustentação deste.

Raízes do Brasil, contudo, não é a única tentativa sistemática de analisar os impasses e bloqueios ao moderno no Brasil a partir de uma consideração de uma estrutura de personalidade e de relações "personalísticas". O conjunto de elementos conceituais sintetizados na idéia de "cordialidade" reaparece de forma bastante intensa - e retrabalhada a partir de outras contribuições teóricas - na obra de Roberto DaMatta, sobretudo nos livros Carnavais, Malandros e Heróis (1997 [1979]) e A Casa \& a Rua (1991). Nessas obras, DaMatta - um dos mais influentes cientistas sociais brasileiros nas últimas três décadas - busca sintetizar uma interpretação geral sobre a gramática social brasileira, a partir de uma abordagem estruturalista. Para isso, DaMatta analisa com atenção uma série de rituais sociais brasileiros, como o carnaval, a procissão, o desfile de sete de setembro e, em um plano mais cotidiano, o uso da expressão "sabe com quem está falando?". Com a análise desses momentos, DaMatta afirma buscar captar as principais cristalizações sociais que expressariam os principais elementos do padrão de sociabilidade no Brasil. Ou seja, a análise dos ritos não se esgota em suas especificidades, mas mira 
a uma imagem holística dos padrões invariantes e das possíveis tensões que marcariam a sociedade em seu conjunto, uma vez que eles seriam um veículo básico de transformação do "natural em social" (DaMatta, 1997: 35).

Em síntese, DaMatta procura descrever como a sociabilidade brasileira se organizaria em um sistema dual; nesse sistema, conviveria uma lógica de relações pessoais estrutural e um sistema individualista legal moderno. Esse sistema dual seria representado de forma mais sistemática pela dicotomia entre a casa - espaço social das relações pessoais - e a rua - um espaço "hobbesiano", onde vigeria fundamentalmente a forma de sociabilidade organizada pelo individualismo. A casa é descrita como o lugar do respeito, da proximidade e da intimidade; a rua é o loca do malandro, da luta, do trabalho e dos aspectos não controláveis da vida social. De forma esquemática, esses dois espaços sociais representariam a "oposição básica da gramática social brasileira" (DaMatta, 1991: 19), uma vez que funcionariam como categorias sociológicas fundamentais a partir das quais DaMatta descreve costumes, ritos, encontros cotidianos e peças culturais marcantes do ser social brasileiro.

O pólo personalista desse sistema dual damattiano pode ser entendido como um desdobramento e uma complexificação da idéia de cordialidade, como apresentada inicialmente por Sérgio Buarque ${ }^{48}$. O rito autoritário do "Sabe com quem está falando?" seria, em síntese, a face autoridade da ausência de uma vigência universal do individualismo entre os brasileiros. Ele serviria para trazer a tona o domínio do pessoal em uma situação em que o sistema de ordenamento individualizante ameaça imiscuir-se: a "pessoa" em situação "hierarquicamente superior" (não necessariamente relacionada a uma estrutura de desigualdades sócio-econômicas, como lembraria reiteradamente DaMatta), lança mão da expressão quando vislumbra a possibilidade de ver-se tratada como indivíduo. Esse ritual autoritário poria a nu a estrutura hierárquica e personalista da sociedade, sendo usado quando o pacto silencioso que sustentaria essa estrutura parece ser

\footnotetext{
${ }^{48}$ DaMatta, como um intérprete recente, consegue absorver diversas peças fundamentais de interpretação do Brasil para elaborar seu esquema explicativo. Dessa forma, além da influência de Sérgio Buarque de Holanda, é nítido o impacto da leitura de Os Donos do Poder e de Casa Grande e Senzala no pensamento desse autor. Isso não é nada estranho, sobretudo porque essas três grandes interpretações da história e dos padrões de sociabilidade brasileiros fornecem uma série de elementos - que podem ser alinhados, contrastados ou tensionados, por certo - que permitem a elaboração de uma imagem do Brasil como uma sociedade tradicional ou semi-tradicional.
} 
ameaçado pela dimensão equalizadora - ele serve para restabelecer a pessoa onde parece poder despontar o indivíduo. Esse seria, portanto, um ritual próprio a um sistema social em que as leis só se aplicariam aos indivíduos, e não às pessoas (DaMatta, 1997: 235).

É importante notar que, apesar de descrever o caráter duplo da gramática social brasileira, DaMatta parece dar muito mais importância à dimensão personalista das relações; elas parecem funcionar como a verdade permanente, passível de ser convocada a qualquer momento, como forma de desmanche dos mecanismos legais individualistas; sempre que possível, as "pessoas" se esforçariam em lançar mão de suas relações como forma de afastarem-se da universalidade das leis, para o seu benefício e o daqueles mais próximos.

DaMatta - apesar de focar-se sobretudo na descrição sincrônica da operacionalização dessa gramática dual (com um denso pólo personalista, como se sugere aqui) - tenta, em diversas passagens, buscar as origens históricas dessa sociabilidade tipicamente brasileira. Para isso, ele baseia-se amplamente em uma teoria da história que tem na Reforma Protestante o seu ponto de virada fundamental, a partir da qual se teriam articulado as formas de racionalidade, de estrutura social e de estrutura da personalidade tipicamente modernos.

"No caso especial do Brasil, tudo indica que temos uma situação na qual o indivíduo é que é a noção moderna, superimposta a um poderoso sistema de relações pessoais... Em formações desse tipo, a oposição indivíduo/pessoa é sempre mantida, ao contrário das sociedades que fizeram sua 'reforma protestante', quando foram destruídos, como demonstra Max Weber, os mediadores entre o universo social e o individual. No mundo protestante, desenvolveu-se uma ética do trabalho e do corpo, propondo-se uma união igualitária entre corpo e alma. Já nos sistemas católicos, como o brasileiro, a alma continua superior ao corpo, e a pessoa é mais importante que o indivíduo. Assim, continuamos a manter uma forte segmentação social tradicional, com todas as dificuldades para a criação das associações voluntárias que são a base da 'sociedade civil', fundamento do Estado burguês, liberal e igualitário, dominado por indivíduos" (DaMatta, 1997: 230; destaque no original). 
Dessa maneira, o Brasil, descendente direto do mundo ibérico católico (ver DaMatta, 1991: 23), teria mantido, como uma típica sociedade "semi-tradicional", um sistema de ética dupla, que explicaria, como se pode perceber pela citação acima, diversas dimensões da vida social e a deficiência da operacionalização de nossas instituições legais.

O esquema esboçado por DaMatta sistematiza em linguajar científico uma percepção muito comum do universo social brasileiro (ver Souza, 2000: 189-198). Ao descrever aquela ética dúplice, ele atualiza nessa linguagem a ideologia do "jeitinho brasileiro", uma dimensão absolutamente corriqueira de nossas autoimagens e base para a elaboração de uma diversidade de teses acadêmicas clássicas (como as aqui trabalhadas) ou contemporâneas, além de elemento central para uma "ideologia de Brasil" com forte caráter conservador ${ }^{49}$. Jessé Souza, em uma polêmica e sistemática crítica à interpretação de DaMatta, aponta que este não fornece um retrato da estratificação social brasileira a partir da qual teria efetividade a vinculação entre indivíduos e "espaços sociais" descrita pelo autor. Abrindo mão do tratamento das desigualdades sociais brasileiras, DaMatta descreveria os valores como algo que "existe independentemente de sua institucionalização, agindo de forma misteriosa sobre indivíduos e espaços sociais" (Souza, 2000: 192).

Essa crítica de Jessé Souza é de extrema relevância, e nos convida a uma série de outros questionamentos, mais próximo da temática aqui em pauta. Como já parece estar claro, DaMatta operacionaliza uma teoria da história eurocêntrica e de forte traço culturalista - seu objeto são as sociedades entendidas de forma isoladas, classificadas ao longo de um eixo de realização humana encabeçado pelas sociedades européias que realizaram suas revoluções protestantes. Em outros termos, diria que DaMatta não parece se preocupar em analisar como, de início, o individualismo ordenador da lógica social tida como moderna esconde em seu bojo relações hierárquicas; porém, para além disso, DaMatta não vislumbra a possibilidade de uma outra narrativa da história mundial, na qual poder-se-ia perceber, porventura, que o individualismo interno à Europa foi gestado à base de

\footnotetext{
${ }^{49}$ Não é por menos que um livro como $A$ cabeça do brasileiro (2007), de Alberto Almeida que acaba por "concluir cientificamente" como as teses de DaMatta seriam as mais corretas para uma interpretação da realidade social brasileira - adquiriu uma imensa notoriedade da mídia e vendeu uma quantidade incomum de cópias, em se tratando de um livro "científico". Para uma crítica a este livro, ver Oliveira (2007).
} 
uma diferenciação no plano internacional que lançou mão de uma série de instrumentos e formas de organização social que não se pautavam pela ideologia individualista européia - como atestam a história da escravidão, do imperialismo e da subalternização dos saberes não europeus, próprias à história da modernidade (ou à sua contra-história, não comumente teorizada).

Voltamos, mais uma vez, ao problema da ontologia do moderno a partir do qual se descrevem os dilemas sociais das sociedades periféricas. Porém, antes de tratarmos diretamente desta questão, é preciso que nos atenhamos ao outro elemento do discurso eurocêntrico presente em ambas as linhagens analisadas até o momento: a idéia de "história imóvel".

\section{A construção de uma "história imóvel"}

O capítulo brasileiro da apropriação da estrutura de referências eurocêntricas não escapa de uma descrição da história do país história como a reiteração de um princípio explicativo. Nas duas versões principais aqui tratadas, os autores (em especial Faoro) dão espaço para que se leiam suas descrições de nossa história como um processo homogêneo: algum traço particular de nossa sociedade é elevado a princípio explicativo dos motivos pelos quais "não nos tornamos uma sociedade moderna". E, em ambos os casos, esse princípio - o próprio obstáculo à nossa modernização - deriva-se de traços herdados de nossos colonizadores, insuficientemente ocidentais.

Essa prefiguração de nossa história nas origens permite a construção de uma "fenomenologia do mesmo": a história da sociedade brasileira, bloqueada, seria um simples transcorrer de formas de expressão de um mesmo princípio antimoderno. A utilização do recurso dos "entraves" é funcional - e em tudo coerente com um discurso eurocêntrico - à descrição de nossa imutabilidade histórica, como contraposição ao outro "ocidental” dinâmico.

O caráter a-histórico do uso da categoria "patrimonialismo" por Faoro já foi diversas vezes apontado (por exemplo, Souza, 2000: 171; Campante, 2003). Faoro faz um exercício, em diversos momentos da obra, de "torção da história" a fim de mostrar que o patrimonialismo estamental, emanando do centro, sufoca o livre 
desenvolvimento da sociedade (Campante, 2003: 159). Esse destino já estaria traçado desde o processo de formação do estado português, delineando-se uma estrutura que perduraria até hoje (Faoro, 1958: 4). O "Estado barroco" português não teria funcionado como fase de transição para um Estado liberal, supostamente ideal para o desenvolvimento do capitalismo industrial, como parece esperar Faoro $^{50}$, em acordo com uma determinada idealização do processo histórico:

"O que há de singular na história da Península não é o fato da existência do Estado barroco. Êle foi no Ocidente uma fase de quase todas as grandes monarquias, com a exceção notável da Inglaterra. A circunstância realmente marcante é a sua permanência de cinco séculos, em estado de congelamento. Perdurou essa estrutura social, sem lograr evolver para a ideologia do capitalismo industrial. Inclusive em suas colônias americanas e nas nações em que se transformaram, estacionou na fase barroca, com a mesma forma e iguais suportes econômicos" (Faoro, 1958: 40-41)

Patrimonialismo "sufocante", "tutelador", "centralista"; “congelamento", "afirmação", "perduração" da estrutura social. Em Faoro, o estado "chinês" instalado no Brasil reproduz uma história "tipicamente oriental". Os bloqueios nos levam a uma história imóvel - a uma "viagem redonda", como aparece na segunda versão da obra. Os "odres velhos" (os mesmos, desde o início) não permitem que se deite "vinho novo". A conseqüência é uma postura resignada de Faoro, mas que ao mesmo tempo aponta para a necessidade de uma ruptura abrupta com os nossos obstáculos: apenas assim poderíamos ter, de fato, uma história:

"As velhas caldeiras, a fim de que se expanda a pressão, hão de romper-se e fragmentar-se em mil peças disformes. A explosão há de ser total e profunda e os velhos odres devem ser abandonados. Somente assim a criança tolhida e enfêrma terá ensejo de crescer e tornar-se adulta. Essas são

${ }^{50} \mathrm{Em}$ texto posterior, a relação entre nossa história imóvel e o tipo de capitalismo que aqui se desenvolveu é mais clara: "Com um sopro, a economia particular é apropriada pelo governo, que redistribui os valores entre categorias econômicas identificáveis. Esta é uma crônica cíclica e repetitiva, que ainda não se concluiu. Este é o pré-capitalismo, o mercantilismo, o 'capitalismo politicamente orientado', o único que conhecemos, fora da teoria e dos livros" (Faoro, 1993: 26). 
as expectativas cegas da fé, que a razão e a análise históricas repelem" (Faoro, 1958: 271).

Sérgio Buarque, mais uma vez, é mais ambíguo quanto à sua retratação da história brasileira. Contudo, não é um exagero afirmar-se que sua leitura sobre o país não se afasta de um paradigma estático sobre seu processo histórico. E, assim como em Faoro, a construção dessa narrativa sobre o Brasil se dá em torno da articulação entre nossos obstáculos à transformação social e a conseqüente reiteração de nossas origens ibéricas - elas mesmas não permitem que realizemos uma ruptura com nosso passado e organizemos uma ordem social "americana". Esse raciocínio fundamental permite que Sérgio Buarque delineie uma narrativa histórica em que processos bastante afastados no tempo (como, por exemplo, os primeiros movimentos de ocupação do território, no século XVI, e o crescimento de nossas cidades e da vida intelectual, no século XIX) sejam explicados pelo mesmo princípio original que aqui encontrou solo fértil: o próprio personalismo ibérico. $O$ passado se ligaria ao presente (década de 1930) por uma reiteração das origens, que, por sua vez, Sérgio Buarque mostra estarem se esfacelando:

\begin{abstract}
"Ainda testemunhamos, presentemente, e por certo continuaremos a testemunhar durante largo tempo, as ressonâncias últimas do lento cataclismo, cujo sentido parece ser o do aniquilamento das raízes ibéricas de nossa cultura para a inauguração de um estilo novo, que crismamos talvez ilusoriamente de americano, porque seus traços se acentuam com maior rapidez em nosso hemisfério. No Brasil, e não só o Brasil, iberismo e agrarismo confundem-se... No dia em que o mundo rural se achou desagregado e começou a ceder rapidamente à invasão impiedosa do mundo das cidades, entrou também a decair, para um e outro, todo o ciclo das influências ultramarinas específicas de que foram portadores os portugueses" (Holanda, 2006: 12).
\end{abstract}

Dessa forma, a superação, assim como em Faoro, parece exigir, em um primeiro momento, uma ruptura com as próprias raízes ${ }^{51}$, somente assim podendo-

\footnotetext{
${ }^{51}$ A semelhança deste argumento com a análise de Lewis sobre o kemalismo como solução para os problemas das sociedades médio-orientais é notável, a não ser pelo fato de Holanda identificar-se com um processo de ruptura que parta "de baixo", dos novos setores
} 
se constituir aqui o "americanismo", uma ordem social dependente de relações impessoais contrárias à nossa tradicional cordialidade. Mas, há de se observar, Raízes do Brasil não é um livro de história, como aponta Sallum: nele, tenta-se reconstruir nossa identidade brasileira "tradicional", exercício para o qual "ele usa a matéria legada pela história para identificar as amarras que bloqueiam no presente o nascimento de um futuro melhor" (Sallum, 1999: 238). A isso, acrescentaria que esse uso do material histórico tende a buscar uniformidades no passado brasileiro, a partir da consideração da reiteração de um princípio de conduta que impede (ou condiciona) nosso acesso ao moderno.

Mais uma vez, é preciso observar que essa obra permite (ou, talvez, exige) uma leitura menos inequívoca sobre a necessidade ruptura com nossas raízes para a construção de uma ordem social moderna, como já nos referimos acima: ao mesmo tempo em que Sérgio Buarque parece pregar a necessidade dessa ruptura, ele adverte que a modernização deverá se basear no "tipo brasileiro", e não em um apego a formas importadas e que nada diriam sobre a realidade da sociedade do país ${ }^{52}$.

Essa parece a questão mais desafiadora de Raízes do Brasil: o iberismo, em suas manifestações na sociedade brasileira, aparece, ao longo de toda a obra, como o mal a se combater; contudo, por fim, ele parece o filtro a partir do qual deveríamos produzir a nossa forma peculiar de modernidade - no final das contas, não uma modernidade exatamente "americana" ou impessoal, mas uma espécie de modernidade encantada (ver Paixão, 2005: capítulo 6). O livro, dessa forma, parece apresentar uma contradição fundamental. Mas essa contradição não deve ser considerada um erro grosseiro: essa "aporia" é uma importante manifestação das dificuldades em se pensar a modernidade na periferia. Sérgio Buarque, lançando mão majestosamente da forma ensaio, realiza uma das primeiras tentativas de fundir, nas palavras precisas me Marcelo Paixão, um projeto de

“...democratização do país com a manutenção da densidade das relações humanas forjada ao longo dos séculos de Colônia e Império. Desta forma poderíamos encontrar um

emergentes da sociedade, fundamentalmente anti-oligárquicos (ver, com relação a esta questão, o controverso capítulo final de Raízes do Brasil).

${ }^{52}$ Para uma interessante discussão dessa questão, ver Piva (1997). 
caminho próprio para a modernização do Brasil, conseguindo evitar o desencantamento que marcava a paisagem social dos países mais avançados" (Paixão, 2005: 488).

Um projeto dos mais difíceis, que ainda assombra uma porção da intelectualidade contemporânea ${ }^{53}$.

\section{Eurocentrismo e periferia}

A busca de explicações sobre as possibilidades de realização da modernidade nas sociedades periféricas é marcada, com freqüência, por uma idéia de incompletude: estas seriam incompletas frente à "civilização ocidental" e aos modelos de evolução social nela baseados; a evolução histórica das sociedades, descritas como "o outro do Ocidente" seria marcada por resistentes entraves à transformação. De acordo com esse discurso, a história das sociedades não pertencentes ao centro ocidental "irradiador da modernidade" pode ser narrada como um "sistema de ausências" - a estrutura de referências eurocêntricas, com suas categorias, temáticas e recursos narrativos forneceria, consciente ou inconscientemente, o quadro adequado para a compreensão sobre os percalços "do Espírito do Ocidente, procurando uma nova morada nesta parte do mundo" (Antônio Cândido, citado por Brandão, 2001).

No caso brasileiro, o "não-Ocidente" dos discursos eurocêntricos parece propiciar uma fórmula útil para a compreensão desta "imundície de contrastes" - na expressão de Mário de Andrade. Frente a esse quadro, é compreensível por que elementos da tradição eurocêntrica foram tão essenciais para fundamentar uma forma hegemônica de fazermos sentido de nossa realidade social e, a partir daí, de orientarmos nossas auto-imagens e nossas práticas políticas, sobretudo em seus elementos de caráter mais conservador ${ }^{54}$. Até hoje, o Brasil é descrito como "país

${ }^{53}$ A polêmica obra de Richard Morse (1988) assim como a importante disputa travada entre
ele e Simon Schwartzman (ver Schwzartzman, 1988 e 1989; Morse, 1989) talvez sejam os
exemplos recentes mais marcantes de disputa em torno das possibilidades e vantagens de
uma "modernidade encantada", de uma "modernidade ibérica", na América Latina.
54 A breve análise de Werneck Vianna sobre a influência da obra de Faoro para a
orientação dos principais atores políticos no Brasil pós-abertura parece-me fornecer o mais
marcante exemplo dessa dinâmica entre interpretações de país e práxis social (ver Werneck
Vianna, 1999). A "afinidade eletiva" entre o diagnóstico histórico e sociológico de Faoro e a 
que nunca muda", ou o "jeitinho brasileiro" é visto como a forma de organizarmos nossa vida em sociedade. Uma variação desse discurso é a "internalização do moderno" para usá-lo como contraponto ao atraso também interno ${ }^{55}$ : O Brasil seria um país cindido entre regiões ou grupos sociais "modernos" e "atrasados"; ou, na fórmula de um conhecido "comentarista" contemporâneo, entre um "Brasil que paga impostos e um que vive de impostos dos outros". O dualismo, presente tanto em no imaginário social brasileiro quanto em importantes teses acadêmicas (ver Arantes, 1992), é a forma internalizada de uma cisão entre modernidade e atraso típica dos discursos eurocêntricos, por nós absorvida e naturalizada ${ }^{56}$.

A apropriação de elementos da tradição eurocêntrica parece ter sido uma das maneiras pelas quais a cultura brasileira buscou resolver uma espécie de malestar congênito, sintetizado brilhantemente por Paulo Emílio Salles Gomes: "não somos europeus nem americanos do norte, mas destituídos de cultura original, nada nos é estrangeiro, pois tudo o é. A penosa construção de nós mesmos se desenvolve na dialética rarefeita entre o não ser e o ser outro" (citado em Arantes, 1992: 15). Essa dialética entre o não ser e o ser outro fornece o mote dramático que, como aponta Arantes (1992: 17), foi explorado pelo ensaio de interpretação do Brasil a partir do problema da "formação".

Esse mal-estar é agravado pela própria condição de termos sido gerados como colônia da "menos européia das Europas" - uma espécie Calibã sob os olhos dos europeus, ao mesmo tempo que um "Próspero calibanizado", do ponto de vista da colônia. Como aponta Santos, a formação da identidade brasileira só poderia se dar por um tenso entrelaçamento entre a negação total do outro português (voltando-se para um "outro" que se assemelhasse mais à sólida figura de um

política neo-liberal da década de 1990 aponta para o caráter conservador mais freqüente de tais interpretações do Brasil que, como tento mostrar, são derivadas dessa estrutura de referências eurocêntricas (ver Souza, 2000; Oliveira, 2007)

55 Esse recurso já estaria presente na obra de Faoro, mas seria desenvolvida principalmente por Schwartzman, em sua conhecida análise sobre o caráter moderno de São Paulo frente ao restante do país, em Bases do Autoritarismo Brasileiro (1982).

${ }^{56}$ A influência do dualismo na experiência intelectual e cultural brasileira é brilhantemente captada pelo filósofo Paulo Arantes (1992). Contudo, parece-me que a sua influência não se teria extinto com a produção intelectual próxima à teoria da dependência e os trabalhos de intelectuais como Roberto Schwarz, analisados por Arantes - apesar de ter sido duramente criticado por estes, como veremos no capítulo 4. Pelo contrário, o dualismo ainda deve constituir uma das formas mais vigorosas de auto-compreensão do Brasil e das outras sociedades periféricas. 
Próspero, como a Inglaterra) e pela disputa com essa identidade subalterna (ver Santos, 2006: capítulo 7).

De qualquer forma, desenha-se um intricado dilema que colocou, ao longo da história intelectual brasileira, o desafio de pensar a modernidade nessa situação de dupla subalternidade.

Como se tentou mostrar ao longo destes dois capítulos, a estrutura de referências eurocêntrica é, no mínimo, insuficiente para uma análise histórica e sociológica sobre o processo de realização da modernidade na periferia do sistema internacional. Essa estrutura funciona como uma espécie de gramática maleável e passível de múltiplas apropriações, porém elaborada a partir de uma experiência histórica - ou de uma auto-consciência acerca dessa experiência - bastante particular, narrada sob o signo da completude.

Dadas as restrições e particularidades desse discurso, como se pode colocar o historiador ou o cientista social frente a essas "sociedades não contempladas pelos clássicos"? Certamente, o processo de constituição de discursos antieurocêntricos sobre a modernidade periférica não passa por um distanciamento absoluto com relação a todas as categorias e formas de pensar que são próprias àquela estrutura de referências - como se poderia, por exemplo, analisar o Brasil sem fazer uso algum da categoria do patrimonialismo, ou as sociedades muçulmanas sem uma consideração sobre o patriarcalismo?

Contudo, o problema parece estar mal formulado, se tomado nesses termos. Como se irá observar nos esforços de autores que tentam constituir teorias antieurocêntricas da modernidade periférica, não se trata de realizar uma espécie de "limpeza conceitual", instituindo-se um índice de termos não-recomendados ou proibidos. A questão que se coloca, como veremos, é como essa diversidade de conceitos pode ser relida e, porventura, reconstruída no interior de uma 
consideração que recoloque o problema da especificidade da modernidade periférica e, a partir disso, da própria modernidade ${ }^{57}$.

Não se trata de uma questão trivial: esse exercício analítico pressupõe um movimento de reorientação teórica, tendo em vista a compreensão histórica dessas realidades sociais específicas. E especificidade entendida não a partir da idéia de um desvio de um padrão histórico, mas como uma justa consideração sobre a realidade da modernidade e do capitalismo periféricos e sobre as dinâmicas sociais próprias a cada uma das sociedades analisadas. Especificidade que, junto de radicalidade, na sábia lição de Francisco de Oliveira (2001), são as condições fundamentais para se pensar o Brasil - e a modernidade periférica, poderíamos acrescentar.

Muitos pensadores sociais já tentaram explorar essas vias tortuosas. É por elas que, com cautela e tentando recompor os seus rastros, tentaremos nos enveredar.

\footnotetext{
${ }^{57}$ Nos termos de Derrida, diria que se trata - tendo-se em mente a especificidade da periferia e sua relação intrínseca em uma modernidade global internamente diversa -, em síntese, de "conservar, denunciando aqui e ali os seus limites, todos esses velhos conceitos: como utensílios que ainda podem servir. Já não se lhes atribui nenhum valor de verdade, nem nenhuma significação rigorosa, estaríamos prontos a abandoná-los a qualquer momento se outros instrumentos parecessem mais cômodos. Enquanto esperamos, exploramos a sua eficácia relativa e utilizamo-los para destruir a antiga máquina a que pertencem e de que eles mesmos são peças. É assim que se critica a linguagem das ciências humanas" (Derrida, 1971: 238)
} 


\section{Modernidade, crítica ao eurocentrismo e o problema da modernidade periférica}

"In Munich, you do not see or feel coloniality. In La Paz,
Bolivia, you feel it all the way, all the time, in your bones:
modernity is constantly reproducing coloniality. Which
means that the rhetoric of progress, of salvation, of
technology, of democracy goes hand in hand with the
logic and practice of oppression, racial discrimination,
political concentration of power in the hand of a Creole/Mestizo/an elite".

Walter Mignolo, $2006^{58}$

\section{Elementos da razão eurocêntrica}

O problema da adequação entre categorias ou teorias e a realidade não é nova. Muito pelo contrário, trata-se de uma questão filosófica fundamental, ou, na verdade, de uma série delas: como atingir o "verdadeiro"? É possível nomear os universais? A realidade é passível de apreensão? Como dar conta da diversidade do dado? Tais questões filosóficas, que atravessam a história do pensamento humano (não apenas ocidental), ganham especial importância no interior da discussão moderna sobre a compreensão das sociedades européias - sociedades em que surge a moderna sociologia, no bojo de um processo de expansão capitalista - e da simultânea compreensão dos seus "outros".

É nesse contexto que surge a sociologia e se institucionalizam as demais ciências humanas, evidentemente imbuídas de uma missão de compreensão científica dos processos sociais. Mas, paralelamente, elas fornecem dinâmica a uma forma de compreensão do real que se centra naquela cisão fundamental que tentei descrever nos capítulos anteriores: uma cisão entre "moderno-ocidental" e "atraso-não ocidental"; entre sociedades dinâmicas e estáticas; impessoais e personalistas; racionais e irracionais, completas e incompletas - no limite, nutrindose e atualizando aquela cisão grega entre civilização e barbárie ${ }^{59}$. Não é de todo

\footnotetext{
58 Mignolo (2006: 495).

${ }^{59}$ A referência a uma proximidade com a dicotomia grega civilização/barbárie não deve ser vista, aqui, como uma tentativa de atestar uma continuidade histórica entre gregos antigos e europeus do século XIX. Como mostram muito bem Dussel (2000) e Shohat e Stam (2006), 
exagerado afirmar que o não-ocidental, ao longo da constituição do eu europeu, passa a compartilhar uma posição de outro da razão ocidental, junto de outras categorias sociais depreciativas - como a "criança", o "louco", o "primitivo", a "mulher" ou "as massas". O pensamento europeu moderno vai lançar mão dessas categorias como forma de definir o terreno em que se assentaria a originalidade e a superioridade histórica dessa civilização. Para citar apenas três exemplos: a moderna psicologia, por exemplo, fundou-se em aproximações entre a personalidade infantil e a "mente primitiva"; a antropologia, ao menos até o início do século XX, debruçou-se sobre uma concepção de "mentalidade primitiva" arraigada na magia e na superstição, sem capacidade de abstração e de elaboração conceitual; e, por fim, como nos lembra Edward Said (1995: 373), sociedades não ocidentais vêm sendo descritas até hoje, em obras de grande circulação, pelo ângulo da patologia e/ou da terapia, como se apreende de títulos como The African Condition (Ali Mazrui, 1980), The Arab Predicament (Fouad Ajami, 1981) e The Republic of Fear (Samir Al-Khalil, 1989).

Apesar de constituírem uma espécie de agrupamento negativo, um "coletivo da regressão", cada um desses elementos conceituais ou sociais depreciados na constituição das principais tradições intelectuais ocidentais na modernidade possui sua história e sua especificidade, apesar de poder-se perceber que há uma grande circulação entre eles. Ou seja, a elaboração conceitual destinada à descrição de cada um desses elementos acabava por fornecer, ao menos, analogias para o desenvolvimento de todas as outras. Não é por menos que diversos autores clássicos, como Montesquieu ou Hegel, aproximam as sociedades não-ocidentais

essa pretensa continuidade - o mito da Grécia como lugar "onde tudo começou" (Shohat e Stam, 2006: 89) - é parte indispensável do próprio discurso eurocêntrico, não encontrando uma verdadeira identidade com a realidade histórica. Porém, essa proximidade deve ser apontada exatamente por esse motivo: o fato de os modernos se identificarem com gregos e romanos (ou com suas instituições - como atestam, por exemplo, a auto-identificação dos revolucionários franceses com os romanos ou a discussão dos últimos dois séculos sobre a democracia) faz com que sejam mobilizadas formas de pensar e ideais de sociedade que pretensamente existiam na "Antigüidade Ocidental", inclusive a dicotomia civilizaçãobarbárie que the era própria e tão impactante na filosofia, nas artes e na política. A propósito, é notável como essa imagem da Grécia como berço da civilização, em oposição a impérios bárbaros, ainda é mobilizada de forma eficaz - e sem maiores rodeios - pela indústria cultural: o filme "300" (2007, direção de Zack Snyder, adaptação para o cinema dos quadrinhos de Frank Miller) talvez seja a mais recente demonstração em massa de como o discurso orientalista é parte central da imaginação social do Ocidente e de como ela se presta a reforçar uma determinada narrativa geral sobre a história da humanidade narrativa que vem de mãos dadas com concepções políticas bastante inequívocas sobre como tratar esse outro, que há tantos séculos atormentaria nossa vivência "moderna", "ocidental", "aos moldes gregos", como se queira. 
de imagens de homens primitivos ou de crianças, ou, como mostram Robert Stam e Ella Shohat, que o cinema ocidental contemporâneo continue a retratar com freqüência o oriental como dotado de uma sexualidade feminina ou ambígua, frente à "masculinidade ocidental” (ver Shohat e Stam, 2006: capítulo 4).

A estrutura de referências e atitudes eurocêntrica que descrevemos anteriormente, nas suas várias versões e apropriações, é penetrante até mesmo nos esforços mais recentes de compreensão científica da realidade das sociedades que não se situam naquilo que se considera o núcleo civilizacional ocidental. Não se trata, portanto, apenas de artigos de um antiquário científico - obras fundadoras das ciências sociais, resquícios de formulações racistas do século XIX ou aplicações imediatas da teoria da modernização à dinâmica dessas sociedades. Há vários indícios de que as antinomias do pensamento eurocêntrico fazem parte de algumas das mais importantes obras recentes que tratam do Brasil e das sociedades árabes e muçulmanas, além de serem altamente impactantes para a dinâmica política interna e para as relações internacionais dessas sociedades.

Essa hipótese - tendo em vista igualmente uma série de esforços atuais de elaboração de discursos críticos anti-eurocêntricos - nos leva a crer que a crítica aos discursos eurocêntricos deve adquirir uma função crítica permanente, passando a fazer parte de nossos aparatos teóricos (e políticos, dada a importância dos temas tratados) cotidianos e assumindo um papel de ponto de partida crítico para uma análise da dinâmica entre pensamento e política e, fundamentalmente, para o estudo dessas sociedades. Estudo, este, entendido como um verdadeiro esforço intelectual de compreensão imbuído de um momento ético de transformação dessa realidade. A formulação de uma teoria crítica da modernidade periférica deve passar, como se buscará mostrar, por um momento de desconstrução das antinomias do pensamento eurocêntrico.

Algumas considerações sobre origens e componentes do discurso eurocêntrico

Neste trabalho, centrei-me apenas em alguns dos elementos da estrutura de atitudes e referências eurocêntricas, sobretudo aqueles que se referem à dinâmica histórica das sociedades não ocidentais. Mas, como se apontou diversas vezes, o 
"Eurocentrismo", em suas várias dimensões, forma uma das bases da própria experiência ocidental da modernidade. Segundo Lander, o eurocentrismo pode ser apresentado, sinteticamente, como a naturalização da sociedade liberal européia como a única possível ou desejável (Lander, 2000: 12). Essa naturalização seria, em seus aspectos epistemológicos, uma das muitas conseqüências de uma separação, fundadora do pensamento político ocidental moderno, entre homem (razão) e mundo. Uma das decorrências dessa cisão é uma pretensa busca de conhecimento descorporeizado e descontextualizado, objetivo e universal, busca essa atrelada a uma noção de progresso, desenvolvida em um contexto de assimetria de poder global.

Para a consciência européia da modernidade ${ }^{60}$, essas sucessivas cisões da realidade articulam-se com aquelas que servem de fundamento ao contraste essencial que se estabelece a partir da conformação colonial e neo-colonial do mundo, entre Europa e os outros. Dito de outra forma, é impossível pensar o "cogito cartesiano" em todas as suas conseqüências e desdobramentos sem pensar o próprio encontro da Europa com seus outros, no início da Idade Moderna. Dessa articulação entre formas do saber e percepções da alteridade, surge um campo teórico, imagético e ideológico que apregoa o suposto caráter universal da experiência européia e que possibilita uma leitura da totalidade da experiência humana a partir dessa particularidade (Lander, 2000: 16-17). Como aponta AbdelMalek (1975: 47), há um caráter setorial no dado que informa a sociologia. Essa setorialidade do dado, que naturaliza uma experiência histórica, é a base para uma história excludente, ou uma história das incompletudes e dos bloqueios.

Tentando captar as múltiplas dimensões desse discurso eurocêntrico, Coronil o define (muito peculiarmente denominando-o de "ocidentalismo") da seguinte maneira:

"conjunto de prácticas representacionales que participan en la producción de concepciones del mundo que 1) dividen los

\footnotetext{
${ }^{60}$ Consciência que é hegemônica, mas não uníssona: por exemplo, a dialética e o ponto de vista da totalidade, seja de um Hegel ou de um Marx, podem apontar para um potencial crítico que não se enquadraria nessa caracterização, apesar de refletirem sobre um momento fundador da modernidade e sobre sua constituição - e apesar de esses autores também serem influenciados pelos discursos eurocêntricos em diversos aspectos de seus pensamentos, como já se indicou. Para uma visão oposta, cuja ressonância entre diversos autores pós-coloniais não pode ser desprezada, ver Young (1990).
} 
componentes del mundo en unidades aisladas; 2) desagregan sus historias de relaciones; 3) convierten la diferencia en jerarquía; 4) naturalizan esas representaciones; y 5) intervienen, aunque sea de forma inconsciente, en la reproducción de las actuales relaciones asimétricas de poder" (Coronil, 2000: 89-90).

Como se pode imaginar e já apontei acima, essas dimensões extravasam a estrutura de atitudes e referências eurocêntricas que descrevi até agora, sobretudo no capítulo inicial. Esta estrutura pode ser compreendida como uma dimensão sociológica daquele discurso eurocêntrico mais amplo, o qual constitui, por sua vez, um dos braços de uma ideologia européia da modernidade. Esses dispositivos sociológicos interiores ao discurso eurocêntrico funcionam como uma espécie de "dispositivo de conhecimento universal" (Lander, 2000: 23) que, ao hierarquizar as diversas experiências humanas e colocá-las ao longo de uma reta que as distancia ou aproxima da experiência da modernidade, permite a descrição das outras formas de vida em sentido negativo, ou seja, como formas incompletas - e não como outras formas de completude, articuladas entre si. Como aponta Quijano, a diversidade dos discursos eurocêntricos lança mão, de formas diversas, de uma articulação lógica peculiar entre um dualismo (presente, como já demonstramos, nos pares atraso/moderno, completude/incompletude...) e um evolucionismo, uma vez que a experiência européia é naturalizada e situada na esfera positiva das dicotomias - de maneira que, por meio de uma realocação temporal, o não-europeu (ou nãoocidental) é percebido como passado (Quijano, 2000: 222).

Em algumas variações desse discurso, vigora uma forma de compreensão do progresso em níveis mundiais que Blaut chama de "difusionismo eurocêntrico". Segundo essa visão, o progresso seria permanente e natural na Europa e não no resto (o que é geral para todo o discurso eurocêntrico), e o progresso nos outros locais e principalmente resultado da difusão de idéias inovadoras e de produtos europeus (Blaut, 2000: xi). Blaut tenta esclarecer que esse modelo de evolução histórica global ganhou realidade e poder com o colonialismo europeu.

O entrelaçamento entre discursos eurocêntricos e a lógica assimétrica de poder global é um dado que não se pode perder de vista. Essa observação é especialmente importante e nos obriga a ler com atenção diversas críticas feitas a autores pós-coloniais e, sobretudo, a Edward Said, no que se refere às bases de 
seu aparato crítico ao discurso orientalista. Em diversos momentos da crítica saidiana (e sobretudo em Orientalismo), o "orientalismo" parece ganhar ares de entidade autônoma de dominação, uma espécie de discurso que se auto-reproduz, inventando um outro para uma auto-invenção e a dominação européias - como se tentou mostrar no capítulo 1.

O que parece escapar a diversas críticas pós-coloniais é a centralidade da "colonialidade do poder" própria à modernidade (Quijano, 2000), ou ao capitalismo instalando-se globalmente. Essa expansão do capitalismo leva consigo formas de conhecimento dominadoras, que se instalam na periferia e são aí, em inúmeros casos, reproduzidas - e, como aponta Coronil na citação anterior, intervêm consciente ou inconscientemente para a reprodução das relações assimétricas de poder dadas. Ahmad nos ajuda a compreender esse processo:

\begin{abstract}
"O que estou sugerindo é que tem havido historicamente todos os tipos de processos - ligados a gênero e classe, etnicidade e religião, xenofobia e intolerância - que infelizmente têm estado em ação em todas as sociedades humanas, tanto européias quanto não-européias. O que deu especial força às formas européias desses preconceitos, na história, com conseqüências devastadoras para as vidas de incontáveis milhões e expressos ideologicamente em racismos eurocêntricos plenamente desenvolvidos, não foi um processo trans-histórico de obsessão e falsidades ontológicas - uma concentração de singular força nos domínios do discurso - mas, muito especificamente, o poder do capitalismo colonial, que fez surgir outros tipos de poderes" (Ahmad, 2002: 133).
\end{abstract}

O que faz o eurocentrismo algo diferente dos outros etnocentrismos é exatamente o capitalismo e seu caráter mundial e assimétrico (ver Dirlik, 2003: 307). A idéia de um discurso eurocêntrico (ou qualquer outra forma de descrever esse conjunto de dispositivos representacionais) só ganha sentido real quando se leva em conta, nos termos de Quijano (2000: 222), a colonialidade do poder própria do sistema-mundo capitalista moderno.

É apenas tendo essa caracterização em mente que se pode avaliar o papel das ciências sociais em todo o mundo periférico, no qual estas adquiriram com 
enorme freqüência 0 papel de formas privilegiadas ${ }^{61}$ do estabelecimento de afirmações sobre a ausência ou os bloqueios à modernidade, ao invés de se constituírem em geradoras de conhecimentos dessas sociedades a partir de suas especificidades históricas, sociais e culturais. Para o caso da América Latina (mas apresentando um quadro de fácil generalização), Lander afirma:

"En América Latina, las ciencias sociales, en la medida en que han apelado a esta objetividad universal, han contribuido a la búsqueda, asumida por las elites latinoamericanas a lo largo de toda la historia de este continente, de la "superación" de los rasgos tradicionales y premodernos que han obstaculizado el progreso, y la transformación de estas sociedades a imagen y semejanza de las sociedades liberales-industriales... A partir de caracterizar las expresiones culturales "tradicionales" o "no-modernas", como en proceso de transición hacia la modernidad, se les niega toda la posibilidad de lógicas culturales o cosmovisiones propias. Al colocarlas como expresión del pasado se niega la posibilidad de su contemporaneidad" (Lander, 2000: 26).

Essa caracterização de Lander sobre a busca da superação dos bloqueios ao progresso e da instauração de uma ordem social liberal assemelha-se à caracterização que Werneck Vianna faz do "americanismo" na história do pensamento social brasileiro (Werneck Vianna, 1997). Para o caso do Brasil (e, se seguimos as pistas de Lander, da maioria das sociedades latino-americanas), o americanismo parece constituir a versão mais vigorosa, em termos intelectuais e políticos, de discurso eurocêntrico.

${ }^{61}$ Certamente isto não é uma descrição exaustiva sobre as ciências sociais nos países que não fazem parte do centro, da mesma forma como nem todo o pensamento produzido neste deve ser descartado como eurocêntrico, orientalista, ideológico ou qualquer coisa do tipo. Como se tentará mostrar mais à frente, as antinomias do discurso eurocêntrico podem ser superadas por uma série de formulações teóricas, muitas das quais da autoria de teóricos advindos de sociedades periféricas. 
Até agora, o que se tentou fazer foi identificar as maneiras como a estrutura de atitudes e referências eurocêntricas impacta na compreensão sobre o desenvolvimento histórico e as dinâmicas sociais em sociedades periféricas. O que se espera que reste de saldo desta reflexão é a inadequação dessas categorias e narrativas na compreensão daquilo a que ela se propõe - as sociedades analisadas a partir desses discursos sociológicos eurocêntricos não são entendidas em sua formação específica, em um quadro que as situe em uma dinâmica social que vai além de suas fronteiras. O que resta é uma descrição de incompletude.

Mas, invertendo tal raciocínio, seria possível pensar o Brasil, as sociedades árabes e muçulmanas e outras sociedades periféricas a partir da idéia de completude? O que haveria se "completado" nessas sociedades, ou, dito de outra forma, como o presente delas pode ser entendido em sua dignidade histórica, sem que ele seja descrito como dado inacabado? Estas questões são uma versão específica daquelas com que iniciamos esta segunda parte. Nosso problema é: que aparatos categoriais e procedimentos metodológicos nos permitem fazer "afirmações verdadeiras" sobre essas sociedades periféricas e, ao mesmo tempo, procedermos a uma crítica da modernidade a partir dessa posição? O momento da crítica deve abrir espaço a um esforço construtivo, que é no que tentarei focar-me, por meio da busca e análise de algumas referências teóricas que buscaram realizar projetos diversos de "descolonização" teórica.

Portanto, sem buscar desenvolver qualquer abordagem nova (o que seria inapropriado e irrealizável para uma pesquisa como esta) ${ }^{62}$, o objetivo das reflexões que se seguem é apontar os caminhos já trilhados por diferentes literaturas e tentar articulá-los à luz de nossos problemas de pesquisa e de nossas hipóteses. A questão fundamental que nos guia é a maneira como os quadros categoriais levam em conta as especificidades do processo de modernização na periferia e as especificidades da modernidade em sociedades periféricas, situando essas

\footnotetext{
${ }^{62} \mathrm{Na}$ verdade, este trabalho teórico se deu paralelamente ao estudo dos processos de modernização nas sociedades que estamos analisando. Este ainda é nosso objeto fundamental, o que exigiu, ao longo da pesquisa, uma consideração teórica mais atenta à especificidade da modernidade em contextos periféricos. O objetivo é que haja uma grande comunicação entre essas duas reflexões, uma vez que ambas se alimentaram mutuamente ao longo desta pesquisa. Não se trata, portanto, de um exercício de reflexão teórica que será posteriormente "aplicado" aos casos, embora a forma de apresentação dos resultados aqui adotada pareça demonstrar esse procedimento.
} 
sociedades em uma dinâmica de modernidade-capitalista global e atendo-se às dinâmicas internas entre grupos sociais.

Esse esforço exploratório parte de uma dissociação entre a modernidade e o Ocidente. Em seguida, analiso a recente literatura sobre as múltiplas modernidades, buscando identificar seus avanços e apontar suas fragilidades. Por fim, tento esboçar brevemente um programa de pesquisa voltado à reflexão sobre um empreendimento teórico que busque superá-las.

\section{Modernidade e Ocidente}

O discurso sociológico eurocêntrico, descrito até o momento, parte de uma premissa sobre as relações entre a modernidade, com suas instituições e modos de vida característicos, e o Ocidente. Aquela teria sido gerada no interior deste: a modernidade seria um "fenômeno ocidental", de forma que ambos, tomados como agregados culturais, poderiam ser vistos como sinônimos. Ocidental, neste sentido, seria, no mais das vezes, equivalente a europeu quando se refere a fenômenos até o século XIX; a partir de então, a América anglo-saxã também passaria a ser entendida como parte desse conglomerado civilizacional. É grande, por certo, a dificuldade e imprecisão em se definir qualquer um desses termos, uma vez que eles parecem congenitamente entrelaçados e são utilizados, em geral, de maneira intercambiável na mais vasta gama de discursos sociológicos, políticos ou do senso comum ${ }^{63}$.

Esta famosa citação de Weber, de sua introdução aos Ensaios Reunidos de Sociologia da Religião, é um caso clássico desse mecanismo de identificação:

No estudo de qualquer problema da história universal, um produto da moderna civilização européia sempre estará sujeito à indagação sobre qual combinação de fatores a que se pode atribuir o fato de na civilização ocidental, e somente nela, terem surgido fenômenos culturais dotados (como queremos crer) de um desenvolvimento universal em seu

\footnotetext{
${ }^{63}$ Entre os autores analisados no capítulo anterior, Bernard Lewis é, provavelmente, o primeiro no "ranking" em termos de identificação entre Ocidente e modernidade (ver, por exemplo, a nota 29 ).
} 
valor e significado. Apenas no Ocidente existe a ciência em um estágio de desenvolvimento que atualmente reconhecemos como válido... o conhecimento sistemático da teologia deve ser atribuído ao cristianismo sob a influência do helenismo, uma vez que existiam apenas fragmentos no islamismo e em algumas seitas hindus... Faltava à geometria da Índia a prova racional; foi este outro produto do intelecto grego também o responsável pela criação da mecânica e da física... Faltava à altamente elaborada historiografia chinesa o método de Tucídides... em todas as teorias políticas indianas faltava um método sistemático comparável ao de Aristóteles... O mesmo ocorre com a arte... música racional - tanto o contraponto como a harmonia -... só existiram no Ocidente... A impressão era conhecida na China. No entanto, uma literatura impressa, viável apenas para impressão e, sobretudo, os jornais e periódicos, surgiram no Ocidente... O próprio 'Estado', como entidade política, com uma constituição racionalmente redigida, um direito racionalmente ordenado e uma administração orientada por regras racionais ou as leis, tudo administrado por funcionários treinados, é conhecido, nessa combinação de características, somente no Ocidente... O mesmo ocorre com a força mais significativa de nossa vida moderna: o capitalismo" (Weber, 2008: 7-9; destaque no original).

A extensão da citação se justifica, dado o enorme número de exemplos de raciocínio eurocêntrico fornecidos por Weber. $\mathrm{O}$ que há de especial interesse é a forma como o autor arrola, ao longo de sua argumentação, uma série de instituições e formas de conduta próprios à idéia de modernidade (inclusive a dele próprio), identificado-as como intrínsecas ao Ocidente. Ciência, Estado e racionalidade (com suas aplicações nas artes, na arquitetura, na teologia...) são instituições que definem tanto o Ocidente (ou a civilização européia moderna, como expressa Weber) quanto a própria modernidade. Essa identidade dos termos faz com que Weber incorra em um certo raciocínio circular, sobretudo porque seu critério de racionalidade, espécie de fita métrica por ele utilizada para avaliar condutas de vida e bens culturais com relação àqueles do Ocidente, é ele próprio ocidental.

Contudo, apontaria ainda outra questão fundamental, anterior a estas: a forma como Weber estabelece o enquadramento de questões que ele se propõe a resolver é que o encaminha por uma via eurocêntrica. A questão sobre os motivos do 
surgimento da modernidade "no Ocidente" é típica de um raciocínio internalista, com maior ou menor proximidade do essencialismo. Esse tipo de formulação do problema - formulação que é uma parte fundamental do raciocínio científico e altamente dependente dos valores do próprio cientista, como, aliás, o próprio Weber afirmaria (ver análise de Löwy, 2007) - baseia-se em uma visão da história mundial que dissocia cada uma das sociedades ou civilizações, tratando-as como unidades ilhadas. Assim, antes de nos atermos às possíveis respostas fornecidas por Weber, é de fundamental importância a análise da idéia de história mundial que orienta sua colocação de perguntas $^{64}$.

Como aponta Demant, o conceito de "Europa", na forma como se desenvolveu ao longo da Idade Moderna, é um produto da era do Renascimento e da Reforma. Até então, o continente teria passado por uma complexa história de unificação e fragmentação que data da Antigüidade, sem que se gerasse uma base comum de identificação cultural. É na época moderna que "Europa" evolui de conceito geográfico para civilizacional. Ao longo do século XVI, esse conceito vai-se constituindo em torno de três critérios: 1) não-islã (exclusão da parte do continente dominado por povos muçulmanos); 2) cristão ocidental (exclusão da parte dominada pelos ortodoxos, na Europa oriental) e 3) enraizamento na Antigüidade Clássica Pagã (identificação com os padrões políticos e estéticos atribuídos aos gregos e romanos pré-cristãos) (Demant, 2007: 27). Demant (partindo da análise de Samuel Huntington, mas a expandindo) procura articular quais seriam as características comuns da civilização ocidental (fruto, como se verá, da expansão da Europa durante a colonização). A lista é longa:

"(1) individualismo e seu corolário...; (2) racionalismo...; (3) domínio da lei...; (4) cristandade; (5) partilha do poder através de instituições representativas...; (6) separação entre Estado e religião, que abriu o caminho para a tolerância religiosa e eventualmente o secularismo e a neutralidade religiosa do

\footnotetext{
${ }^{64}$ Nos termos de Muryatan Barbosa: "Quando aquele se pergunta: porque o capitalismo nasce no Ocidente? A resposta pode ou não ser pertinente, assim como pode ou não ser tida como cientifica. Mas, de fato, ao ser colocada, tal pergunta está intrinsecamente viciada, porque, como observa Ortiz [ORTIZ, Renato (2000). Um outro território: ensaios sobre a mundialização. São Paulo: Olho d'Água], a idéia de Ocidente pressupõe uma oposição binária, falsa, à de Oriente".
} 
espaço público; (7) pluralismo, a legítima coexistência pacífica de grupos e projetos mutuamente incompatíveis dentro de uma sociedade...; (8) feudalismo e capitalismo; (9) a crença no progresso e na perfectibilidade e emancipação...; (10) a ciência como método universal para a aquisição de conhecimento objetivo...; (11) direitos civis e humanos universais...; (12) a soberania do povo, encarnada na cidadania e democracia participativa...; (13) autodeterminação da nação e nacionalismo, encarnados no Estado-nação independente...; e finalmente (14) a idéia da irmandade dos homens, da responsabilidade mútua, justiça social e paz... A fim de que a lista acima não soe demasiadamente idealista, adicionemos que (15) escravidão, (16) racismo e (17) guerra, militarismo e expansionismo têm diversas vezes sido propostos como marcas do Ocidente!" (Demant, 2007: 41-42).

E com relação ao conceito de "modernidade"? É possível perceber, na maioria das teorias sociológicas clássicas (já tratadas, em parte, no primeiro capítulo deste trabalho) e contemporâneas que Ihes dão continuidade, a identificação da modernidade com um princípio que se materializa em instituições e modos de vida. Habermas (2002: 28), ao analisar o núcleo fundamental dos discursos filosóficos da modernidade, busca decantar o princípio da subjetividade como aquele que articularia as suas várias manifestações. Esse princípio, presente ao menos desde Descartes, seria apreensível por meio do individualismo, do direito à crítica, da autonomia da ação e da filosofia idealista que iriam se constituir no Ocidente. Para Habermas, os acontecimentos chave para a instauração desse princípio e, portanto, da própria modernidade, teriam sido a Reforma Protestante, o lluminismo e a Revolução Francesa. Esses eventos teriam instituído uma nova consciência histórica que, por sua vez, teria exercido influência sobre diversas esferas da experiência humana (e européia, fundamentalmente).

Esse princípio, a subjetividade, articulador global de uma "forma de ser" moderna, determinaria as várias manifestações da cultura moderna, como a ciência, a moral, a arte (sobretudo o romantismo), a religião e o Estado. A filosofia, a partir de Hegel, teria então mudado de estatuto: "...assim que a filosofia tem de refletir sobre seu novo lugar na história, a teoria - a apreensão da verdade - recebe um índice histórico" (Habermas, 2001: 169). Segundo Habermas, esse processo ter-se- 
ia articulado, primeiramente, no pensamento de Hegel. Em seu pensamento, a modernidade passa a compreender-se a si mesma, em oposição à tradição; a modernidade teria de se estabilizar a partir da única autoridade que não teria sido destronada com as revoluções européias: a razão.

Habermas não se esforça em se distanciar de uma descrição das origens ocidentais da modernidade; as experiências históricas que orientam seu diagnóstico da modernidade são aquelas próprias às revoluções políticas do século XVIII e suas conseqüentes manifestações culturais, valorativas e filosóficas. Dessa forma, para Habermas, a modernidade nasceria como um "projeto" no século XVIII, em solo europeu, com a instauração do princípio articulador da subjetividade e - seguindo diagnóstico de Weber - com a separação das esferas de valor:

"The Project of modernity formulated in the 18th century by the philosophers of the Enlightenment consisted in their efforts to develop objective science, universal morality and law, and autonomous art, according to their inner logic. At the same time, this project intended to release the cognitive potentials of each of these domains to set them free from their esoteric forms. The Enlightenment philosophers wanted to utilize this accumulation of specialized culture for the enrichment of everyday life, that is to say, for the rational organization of everyday social life" (Habermas, 1981: 9).

Em sua disputa com teóricos "pós-modernos", Habermas chega a tentar formular uma crítica à acusação destes sobre o caráter imperialista dos valores e instituições modernos ocidentais. A resposta de Habermas é típica de seu "universalismo europeu":

"As abordagens pós-modernas denunciam com razão os efeitos colonizadores dos padrões de comunicação e discursos de origem ocidental que estabeleceram um domínio mundial. Isso vale para uma grande parte da cultura material e simbólica da civilização ocidental que se difundiu pelas teias globais dos mercados e mídias. Mas essas teorias estão mal equipadas para a tarefa de diferenciar entre os discursos colonizadores e os convincentes, entre os 
discursos que devem a sua divulgação mundial a coerções sistêmicas e outros que se impuseram graças à sua evidência. A ciência e a tecnologia ocidentais são eficazes e convincentes não apenas segundo padrões ocidentais" (Habermas, 2001: 189).

A partir das considerações de Habermas e Demant, algumas breves conclusões podem ser avançadas. A justaposição entre as definições de modernidade e civilização ocidental (como entidade civilizacional, em suas características "positivas"), apreensível a partir das definições tomadas desses autores, esclarece as maneiras como os dois conceitos vão se definindo simultânea e mutuamente ao longo da Idade Moderna, época tanto de criação de um "eu" europeu quanto de sua expansão e de seu confronto com diversos "outros", em suas empreitadas coloniais. Essa afirmação ganha maior sentido se lida à luz dos autores analisados no capítulo inicial: mesmo a obra de Montesquieu, anterior às principais revoluções burguesas européias, já estabelece o terreno para esse entrelaçamento entre um conjunto de valores, práticas e instituições que, posteriormente, seriam chamados de "modernidade" e uma espécie de "unidade civilizacional" geograficamente definida, seja ela definida como "Europa", em um primeiro momento, ou como "Ocidente".

Como mostra Demant, a idéia de "Ocidente" vai-se constituindo a partir da expansão da idéia de Europa, como conceito civilizacional:

\footnotetext{
"A idéia era inicialmente menor do que o continente, mas gradativamente se expandiu para incluir todo o continente, e incorporar vastas áreas fora dele, criando no processo uma nova idéia: a do 'Ocidente'... Essa guinada foi conseqüência direta dos descobrimentos e da colonização que abriram novas áreas para assentamento europeu no além mar" (Demant, 2007: 28).
}

Essa observação de Demant sobre a criação do conceito de Ocidente abre uma porta importante para reflexões sobre o caráter "ocidental" de uma série de regiões do globo. Essas reflexões nos são de enorme valia para a desconstrução da identificação entre modernidade e Ocidente. A colônia "é" e "não é" ocidental, 
simultaneamente. Esse traço "colonial do poder europeu", que se impõe paulatinamente por vastas áreas e imensas porções da população mundial, cria sociedades de "dupla consciência". Mignolo, remetendo-se às análises de DuBois, fala sobre a "consciência dupla" do homem formado pela colonialidade - dupla, exatamente porque subalterna (Mignolo, 2000: 63-64). Esse princípio é a característica central do imaginário do mundo moderno-colonial a partir das margens dos impérios europeus. A colônia é, ao mesmo tempo, "mesmidade e diferença" (Mignolo, 2000) $^{65}$. Essa problemática do pertencimento ao Ocidente é um dos temas mais caros à reflexão cultural e sociológica no Brasil - o caráter bifronte das elites coloniais brasileiras (Cardoso, 1975), as obras de Machado de Assis e as reflexões de Roberto Schwarz sobre elas a partir da consideração sobre as "idéias fora do lugar" são grandes testemunhos dessa forma de ser colonial e pós-colonial e do sentimento de dualidade próprio à experiência periférica (ver Arantes, 1992) ${ }^{66}$.

Esses problemas, aqui apenas esboçados, são caminhos a serem percorridos para a problematização daquela identificação inicial entre modernidade e Ocidente que orienta os discursos sociológicos eurocêntricos. Colocar em questão essa identificação imediata constitui um exercício crítico central para uma reconsideração do aparato teórico das ciências sociais (ou de parte hegemônica delas), que vim tentando desenvolver até o momento. A identificação entre Ocidente e modernidade não fornece os recursos teóricos a partir dos quais se pode realizar uma análise da modernização e da modernidade periféricas: o "fenômeno periférico" se esvai, ou é reservado ao tratamento eurocêntrico da incompletude. Como afirma Abdel-Malek com relação às teorias sociais eurocêntricas, o problema crítico fundamental é a reestruturação do aparato conceitual: "O que é real é racional. E este real racional é o do centro hegemônico. É, portanto, a partir de uma exigência de racionalidade que está no centro de toda preservação social e de todo projeto social histórico que as sociedades não ocidentais são convidadas a se ajustar ao modelo ocidental" (Abdel-Malek, 1975: 45). "Modelo ocidental" que, no discurso eurocêntrico, pode ser substituído por "modernidade".

\footnotetext{
${ }^{65}$ Essas considerações de Walter Mignolo serão retomadas mais à frente.

${ }^{66}$ Esses problemas já vão sendo arrolados como forma de tensionar o próprio conceito de modernidade e sua identificação com o Ocidente, levando-me já a sugerir, desde agora, a fecundidade crítica de uma consideração sobre a "gênese" global e a diversidade de formas de realização da modernidade.
} 
Stuart Hall fornece uma importante contribuição para um projeto de dissociação entre as categorias de modernidade e Ocidente. Esse autor analisa as formas como essas duas "entidades" são constituídas como objetos discursivos. O conceito de "Ocidente" seria um significante que se ligaria a uma grande e fluida cadeia de significados (Hall, 1992). Hall lista quatro áreas principais em que ele circula e opera. Primeiramente, ele funciona como uma categoria analítica que permite mapear o mundo em termos de "Ocidente" e "não-Ocidente". Além disso, ele é um critério pelo qual se podem fazer julgamentos sobre o resto do mundo - tanto espacial quanto temporalmente. Em terceiro lugar, ele marca uma fronteira em torno da qual uma grande variedade de qualidades positivas e negativas podem ser reunidas. Por fim, "Ocidente" é um termo que representa uma forma de vida particular: desenvolvida, industrializada, urbanizada, capitalista, secular e moderna (Hall, 1992: 277). A partir dessa conceituação de Ocidente e da análise de sua operacionalização, Hall identifica as bases discursivas da identificação, no discurso eurocêntrico, entre as idéias de modernidade e Ocidente. Como aponta Sayyid, essa identificação indica que o termo "Ocidente" refere-se a um projeto: o Ocidente é uma formação ideológica centrada no discurso da modernidade (como vimos, sobretudo, no pensamento contemporâneo de Habermas).

Segundo esse aparato conceitual, a díade "modernidade-não modernidade" é equivalente à díade "Ocidente-Resto" (Sayyid, 2003: 101-102). E a decorrência desse ponto de partida não pode ser outra: modernização passa, na maioria das vezes, a ser sinônimo de ocidentalização.

Kaya expressa bem o "resumo da ópera":

"In short, modernity emerged as an outcome of a specific civilization, therefore, if the rest wanted to join modern life, they would have first to westernize. In other words, for the rest of societies to modernize, they would first need to 'deeasternize ${ }^{, 67}$. Therefore, the West was not only a particular way of life - democratic, civilized and so on - it also had the historical mission of 'universalizing' human societies" (Kaya, 2004: 50).

67 "De-easternize" como abandono da própria identidade, ruptura dos bloqueios à ocidentalização - sejam essas sociedades "orientais" ou de qualquer outro espaço geográfico periférico, como tento argumentar neste trabalho. 
Tudo leva a crer que esse conceito de modernidade que aqui procuro criticar é unidirecional, não comportando em si a possibilidade da diversidade. Essa visão eurocêntrica da modernidade não comporta a contingência histórica e a agência humana, que condicionam as múltiplas formas de sua realização - tanto em contextos periféricos quanto ocidentais (uma vez que a uniformização do Ocidente é o negativo do discurso eurocêntrico). Nesse sentido, esforços diversos para uma teoria crítica da modernidade periférica não constituem apenas tentativas de pensar novas categorias a serem contrapostas àquelas próprias ao pensamento eurocêntrico. Antes, pensar criticamente a partir da periferia parece significar examinar as várias formas desse pensar eurocêntrico para descobrir que questões ele permite colocar e quais outras ficam excluídas, esquecidas ${ }^{68}$. O que se perde, então, ao se eleger a estrutura de referências eurocêntricas como a narrativa mestra da modernidade? Por fim, como se vem tentando pensar para além dessa estrutura e, evidentemente, quais os possíveis ganhos críticos e analíticos dessas tentativas de superação?

Essas considerações e questões nos conduzem ao exame de uma literatura recente que busca solucionar os dilemas do discurso sociológico eurocêntrico. Sua análise servirá para 0 aprofundamento das reflexões teóricas sobre as modernidades periféricas e para o delineamento de um programa de pesquisa crítico aos discursos eurocêntricos.

\section{Uma tentativa de inserir a diversidade: a abordagem das múltiplas modernidades}

Desde meados da década de 1990, diversos cientistas sociais vêm desenvolvendo uma perspectiva teórica que busca romper o viés eurocêntrico nos estudos teóricos e empíricos sobre a modernidade, em suas múltiplas manifestações. Não se trata, evidentemente, da primeira tentativa neste sentido - e, por certo, nem da mais bem acabada, inclusive pelo fato de os estudos informados

\footnotetext{
${ }^{68}$ Parece ser uma consideração deste tipo dá sentido a um recente trabalho brasileiro como o de Jessé Souza (2003), uma das poucas iniciativas contemporâneas a problematizar este tipo de questão na academia brasileira.
} 
por essa perspectiva serem bastante recentes. Contudo, pela posição que vem adquirindo nas ciências sociais e pelo peso do desafio que lança ao discurso eurocêntrico - ao menos no nível da nomenclatura, pela ousadia de tratar a modernidade no plural -, considero adequado tratá-la antes de qualquer outro discurso sociológico que se esforce por colocar em questão a identificação entre Ocidente e Modernidade própria à estrutura de referências eurocêntricas hegemônica na história do pensamento social moderno.

A perspectiva das múltiplas modernidades (perspectiva, pois não seria pertinente tratá-la como teoria) centra-se, sobretudo, em uma análise cultural, ou civilizacional. O principal teórico da escola, Shmuel N. Eisenstadt, desenvolve um claro esforço de ampliação do diagnóstico weberiano da modernidade para que esse possa adequar-se ao estudo dos modos como as outras civilizações (estas, definidas sobretudo em termos religiosos, ao menos por Eisenstadt) realizam de formas diversas a modernidade (Eisenstadt, 2000). Outra contribuição teórica relevante é a de Charles Taylor, o influente filósofo canadense. Este autor, junto de Benjamin Lee, aponta que a maioria das teorias da modernização é "acultural". Esse tipo de teoria postularia que qualquer sociedade pode passar por um processo de modernização que as levaria a um resultado final bastante semelhante. As teorias aculturais tendem a descrever essa transição em termos da perda das crenças e solidariedades tradicionais devido a mudanças institucionais, demográficas ou da crescente operacionalização da razão científica.

Essa "tese da convergência" é o principal alvo de crítica da perspectiva das múltiplas modernidades (Taylor e Lee, s. d.). Segundo aquela postura eurocêntrica criticada, a modernidade, para sociedades que não fazem parte de seu centro irradiador, apareceria como um ponto de chegada - nesse processo, como não poderia deixar de ser, "this means, of course, that we expect they will end up looking like us" (Taylor e Lee, s.d.). Como se pode apreender do que foi mencionado anteriormente, essa perspectiva descrita por Taylor não se resume à teoria da modernização, tão em voga até a década de 60 - apesar de as várias vertentes dessa teoria serem o alvo principal dos teóricos das múltiplas modernidades. Como aponta Smith, esse modelo eurocêntrico, mais ou menos etapista, continua a exercer efeitos poderosos sobre as ciências sociais por meio de um "background" residual de hipóteses e modelos de pensamento, mesmo quando o acadêmico não é um "modernization scholar" (Smith, s.d.: 1). 
Eisenstadt tenta desenvolver a idéia de que o processo de modernização não equivale ao de ocidentalização. Ele busca descrever as várias formas pelas quais os processos de diferenciação estrutural desenvolveram-se nas diversas culturas do globo, gerando múltiplos padrões institucionais e ideológicos. Esses padrões, contudo, não seriam meras continuações das tradições de cada uma dessas sociedades: cada um deles é distintivamente moderno, apesar de fortemente influenciados pelas suas premissas, tradições e experiências culturais. Eisenstadt resume da seguinte maneira o projeto (em construção) das múltiplas modernidades:

The idea of multiple modernities presumes that the best way to understand the contemporary world - indeed to explain the history of modernity - is to see it as a story of continual constitution and reconstitution of a multiplicity of cultural programs. These ongoing reconstructions of multiple institutional and ideological patterns are carried forward by specific social actors in close connection with social, political and intellectual activists, and also by social movements pursuing different programs of modernity, holding very different views on what makes societies modern. Through the engagement of these actors with broader sectors of their respective societies, unique expressions of modernity are realized (Eisenstadt, 2000: 2).

O raciocínio de Eisenstadt implica que, apesar de a "modernidade ocidental" gozar de precedência histórica e de continuar sendo o ponto de referência para as outras sociedades (ou civilizações), ela não constituiria qualquer tipo de modelo "autêntico" de modernidade (Eisenstadt, 2000: 3). Além disso, a própria cristalização da modernidade européia não teria sido um processo unidirecional e pacífico, mas teria derivado de uma série de lutas, internas e externas, assentadas nas contradições e tensões próprias do desenvolvimento do capitalismo, da constituição dos estados e das disputas pela democratização. Com a expansão européia no início da Época Moderna, sobretudo nas Américas, teria havido a primeira transformação das premissas da ordem cultural e política daquela modernidade em gestação (Eisenstadt, 2000: 13). Essa consideração de Eisenstadt o leva a postular que "a modernidade" já nasceu múltipla, mas a partir de variações do modelo europeu - algo que parece se manter em todo o raciocínio de Eisenstadt: “... 
practically from the beginning of modernity's expansion multiple modernities developed, all within what may be defined as the Western civilizational framework" (Eisenstadt, 2000: 13).

As considerações teóricas de Eisenstadt, apesar de avançar com relação à conceituação de modernidade, ainda sofre de um certo grau de "difusionismo". Isso ocorre apesar da defesa de Eisenstad de que a civilização européia e seus produtos e manifestações não são imediatamente transplantados em outros lugares do globo. Para o autor, a modernidade "se moveu" ao redor do globo, por meio do colonialismo e do imperialismo, dada a superioridade militar, econômica e tecnológica européia. Como aponta Schmidt, os proponentes da abordagem das múltiplas modernidades (e isso é verdadeiro, sobretudo, com relação às contribuições de Eisenstadt) concordam com os teóricos da modernização que o "projeto da modernidade", "a partir do momento em que ele firmemente deitou raízes no Ocidente, começou logo a ter uma relevância global e a espalhar-se para o que às vezes é depreciativamente chamado de 'o resto'” (Schmidt, 2007: 149). Esse parece ser, entretanto, um ponto de tensão no interior do projeto, uma vez que outros autores, como Göle (2000 e 2002) e Kaya (2004), por exemplo, insistem muito menos na questão da expansão e da seguinte diferenciação de uma modernidade "original" - apesar de não "autêntica", como a descreve Eisenstadt. De qualquer forma, um ponto importante em que insiste Eisenstadt e outros autores que compartilham dessa perspectiva é a idéia de que a realização da modernidade nas diversas sociedades e civilizações deriva-se de uma permanente seleção, reinterpretação e reformulação das idéias importadas, originárias fundamentalmente da "civilização ocidental" moderna.

O processo de "modernização seletiva"69 permite estudar como as múltiplas manifestações daquele projeto original de modernidade se realizariam em sociedades de modernização posterior. Entretanto, é preciso apontar que, até o momento, os principais trabalhos que se inserem nessa perspectiva não se centraram nas disputas internas, mas nas formas como as tradições culturais

69 Tomo emprestado aqui o título do livro de Jessé Souza (2000) que, apesar de não mobilizar a perspectiva das múltiplas modernidades, fornece um ótimo e sofisticado exemplo de um estudo que tenta entender a realização específica (no caso, no Brasil) da modernidade a partir de um processo "seletivo", resultado das disputas e disparidades de poder entre grupos internos. 
impactaram na constituição de cada uma das modernidades. O argumento de Eickelman é exemplar desse ponto de vista:

\begin{abstract}
'Traditions' are clusters of cultural concepts, shared understandings, and practices that make political and social life possible. Such pervasive cultural understandings play a crucial element in constituting what we now recognize as 'multiple modernities'. They coexist with and shape the experience of modernity. In this sense, ethnicity, caste, and clientelism can be as distinctively modern as the idea of individual choice (Eickelman, 2000: 122).
\end{abstract}

Taylor e Lee, no mesmo sentido, afirmam que o principal motivo pelo qual se pode falar em múltiplas modernidades é o fato de que o ponto de partida cultural deixa suas impressões no resultado final. Uma transição de sucesso para a modernidade exigiria que um povo encontrasse recursos em sua cultura tradicional que, modificados, permitiriam que eles dispusessem das novas práticas. A esse processo os autores dão o nome de "adaptação criativa" (Taylor e Lee, s.d.). Dessa maneira, a modernidade, nessa perspectiva, cristaliza-se em torno das grandes civilizações - como a européia, a islâmica, a hindu, etc. -, sendo que cada uma delas deixaria suas impressões nas instituições da sociedade, "dando-lhes suas forma e 'cor', por assim dizer" (Schmidt, 2007: 150), ou seja, constituindo modernidades particulares a partir da absorção de valores e instituições que se conformassem de formas específicas com os dados culturais formadores de cada uma dessas civilizações.

É de se observar, inicialmente, que a perspectiva das múltiplas modernidades busca fornecer uma séria resposta ao tratamento das sociedades não-ocidentais como formas insuficientes de realização da modernidade. Como argumenta Kaya, essa perspectiva procura oferecer ferramentas para o tratamento da modernidade como um horizonte aberto, em que existiria espaço para múltiplas interpretações. $A$ modernidade não é um projeto definido e civilizacional, mas um campo de tensões (Kaya, 2004: 38). Ao entendê-la dessa maneira - ao invés de vê-la como uma linha de chegada, um desiderato de uniformização - esses autores propõem essa significativa ruptura epistemológica, que possibilita a compreensão da modernidade como um programa que incluiria a multiplicidade, a contingência: 
Thus, it may be said that since, contrary to postmodernism, modernity is an open, rather than a closed, way of life, it is not necessary to work outside modernity... Because modernity is in the streets, rather than being a programme, plural and different life perspectives compete for the good life. What could be emphasized is that modernity is an endless trial, because no centre provides the 'content' for social life (Kaya, 2004: 47-48; destaque meu).

Uma modernidade "que está nas ruas" é uma maneira astuta de definir um projeto teórico que busque dar conta das formas concretas de realização da modernidade e tente afastar-se de uma forma de discurso eurocêntrica ou da idéia da modernidade como um "projeto", fundamentalmente normativas.

Apesar dos avanços da perspectiva das múltiplas modernidades que se tentou brevemente expor até o momento, é preciso apontar que o projeto ainda demonstra uma série de inconsistências, além de basear-se em pontos de partida teóricos problemáticos que limitam a extensão possível de seus desdobramentos. As críticas que a seguir serão arroladas são os motivos principais de nossa consideração da necessidade de se avaliarem outras tradições teóricas anti-eurocêntricas, que permitam uma consideração da modernidade periférica para além da diversidade oferecida por essa perspectiva.

Inicialmente, é necessário apontar que os autores que vêm trabalhando no interior dessa perspectiva - sobretudo aqueles que seguem mais de perto as abordagens teóricas de Eisenstadt - centram-se demasiadamente na realização civilizacional ou religiosa da modernidade. Esse ponto de partida teórico reduz drasticamente as potencialidades do próprio projeto, além de resvalar em um sério risco de essencialização - não mais uma essencialização dicotômica, como aquela que é própria do discurso eurocêntrico, mas uma essencialização de cada um dos conglomerados humanos tratados como civilizações. Essas vias abertas no interior da perspectiva das múltiplas modernidades correm o risco de desembocar em armadilhas muito semelhantes às daquelas formas de teorização que ela buscava superar. Spohn (2006: 5) aponta que, mesmo trabalhando no interior desse tipo de paradigma civilizacional, essa perspectiva relega a um segundo plano uma análise 
da interação entre as diferentes civilizações - crítica que é complementar à anterior, que aponta os riscos da essencialização.

Além disso, a escolha dos padrões culturais tradicionais como ponto de partida para a análise da absorção do moderno incorre em um risco de não se levantarem questões relevantes acerca de diferenças sociais no interior de civilizações ou de estados. Dito de outra maneira, os trabalhos informados por essa perspectiva não se atêm à estratificação social e às disputas que envolvem a "escolha" das formas de participação na modernidade (apesar de se referirem a clivagens internas, mas sem que isso seja incorporado de forma efetiva em seus aparatos teóricos ou em suas análises de sociedades específicas ${ }^{70}$. Não se trata, aqui, de uma sugestão para que se substitua uma perspectiva civilizacional ou nacional por uma de classe, mas da necessidade de se incorporar ambas ${ }^{71}$. Uma abordagem teórica que pretenda explicar os processos de modernização em sociedades periféricas deve ser capaz de explicar a dialética entre o universal e o particular, ou entre o externo e o interno, envolvida nesse processo. Não me parece, por exemplo, que uma reflexão sobre a "modernidade italiana" informada por essa perspectiva se ateria ao problema crucial, classicamente formulado por Gramsci, acerca da "Questão Meridional" (ver Gramsci, 1987), ou seja, o problema das relações entre o norte o sul da Itália em sua passagem para a modernidade capitalista e as conseqüentes disparidades sociais entre as duas regiões.

Além disso, o fato de centrar-se quase exclusivamente em variáveis culturais afasta essa perspectiva de uma consideração mais atenta à lógica do capitalismo

\footnotetext{
${ }^{70} \mathrm{Knöbl}$ aponta que a América Latina foi uma região praticamente esquecida pelos estudos informados pela perspectiva das múltiplas modernidades. Ele observa que "...uma das razões desse esquecimento está com certeza ligada ao fato de que os debates sobre a posição da América Latina se deram no âmbito da teoria dos sistemas mundiais ou da teoria da dependência. Visto que ambas tendem a diminuir a importância de momentos culturais tão relevantes para a maioria dos autores que defendem o paradigma das 'múltiplas modernidades', é perfeitamente compreensível que poucos desses autores ousem penetrar no campo dos estudos latino-americanos (Knöbl, 2006: 505)". Essa observação de Knöbl é complementar ao que se afirmou até o momento e mostra a pertinência de abordagens teóricas que levem em conta tanto a economia política quanto as dinâmicas culturais envolvidas nos processos de modernização periféricos.

${ }^{71}$ Essa advertência serve para que esta observação não se assemelhe ao tipo de crítica apresentada por Francisco Weffort às perspectivas da dependência. Weffort aponta uma ambigüidade entre nação e classe no interior dos estudos de dependência, além de afirmar que uma teoria de classes não precisaria de uma premissa nacional para explicar o desenvolvimento capitalista (Weffort, 1971). A resposta de Cardoso, que considero bastante consistente, aponta para a inexistência de uma cisão metafísica entre interno e externo: a dinâmica interna dos países dependentes é um aspecto mais particular da dinâmica externa do mundo capitalista (Cardoso, 1979).
} 
mundializado e às diferentes inserções nele de estados e regiões. Essa, provavelmente, é a grande diferença entre essa perspectiva e os estudos sobre a dependência - que podem ser entendidos como uma extensão e uma atualização das teorias do imperialismo, mas com a atenção voltada para as dinâmicas internas aos países periféricos. Ao não dar centralidade ao capitalismo, esses autores não conseguem realizar uma adequada análise das disparidades de poder global que marcam o sistema internacional - seja desde o século $\mathrm{XVI}$, com a expansão marítima européia, seja desde o século XVIII, com a Revolução Industrial (para essa discussão, ver Demant, 2007, e Blaut, 2000).

A idéia de uma "adaptação criativa" ou de um caráter seletivo da absorção da modernidade, se não se atém a essas disparidades materiais (que se convertem e enredam-se em vantagens simbólicas), parece sugerir que existe um mercado de práticas e padrões de sociabilidade modernos à disposição de cada uma das sociedades ou civilizações, que devem prová-los para ver qual combina melhor com seu porte físico "tradicional". Como afirma Dube:

\footnotetext{
"In speaking of modernities are we merely saying that Indian modernity is different from German modernity, which is then different from, say, Mexican or Venezuelan modernity? If this is the case, what modalities of power are occluded here, not only in relation to authoritative grids of empire and globalization, but also within non-Western formations of state and nation? Equally, by invoking a bloated and singular modernity centered on the West in order to interrogate the homogenizing impulses of projects of power, do we perhaps succumb to reified representations of an imaginary but tangible Europe that overlook the labor of difference within the work of domination?" (Dube, 2002: 200).
}

A partir do que se tentou expor até aqui, parece-me bastante convincente a hipótese de que a perspectiva das múltiplas modernidades pode servir, no máximo, como um primeiro momento lógico de superação do discurso eurocêntrico. Ao tratar as modernidades no plural, esses autores implodem inicialmente as dicotomias do pensamento eurocêntrico, uma vez que apontam a não unicidade histórica da realização da modernidade segundo um molde específico. Dessa forma essa perspectiva propõe o desafio de lançar um olhar para a modernidade como algo 
diferente de um ponto de chegada ou de um padrão de averiguação da completude de experiências históricas. Contudo, essa perspectiva deve ser complementada por outras abordagens que superem suas fragilidades, aproximando-nos de um programa teórico aberto e eclético que leve em conta diferentes tentativas teóricas de superação dos discursos sociológicos eurocêntricos e que nos aproxime de uma conceituação de modernidade que propicie uma justa análise da modernidade em sociedades periféricas. A superação de suas fragilidades significa, sobretudo, que se deve pensar em maneiras de teorizar a história da modernidade e de sua constituição como uma história global ou como um conjunto de histórias entrelaçadas, para além do quadro de diversidade apresentado por essa perspectiva.

Portanto, o momento da diversidade deve dar lugar ao momento da dialética entre a modernidade como processo universal e suas múltiplas realizações particulares. Os caminhos que seguimos até o momento e as críticas apresentadas tanto às diversas formas de discurso eurocêntrico quanto à perspectiva das múltiplas modernidades apontam para a consideração da modernidade como um fenômeno global, como uma totalidade de totalidades, estas realizações específicas daquela modernidade global. Esse programa de reorientação teórica é expresso de maneira bastante contundente, entre outros, por Timothy Mitchell:

"... the significance of allowing the non-West to disrupt the history of the West is to show that the West has no simple origin, despite its claim for uniqueness, and its history cannot adequately be gathered into the form of a singular narrative. It is not that there are any different modernities. Modernity, like capitalism, is defined by its claim to universality, to a uniqueness, unity, and universality that represent the end (in every sense) of history. Yet this always remains an impossible unity, an incomplete universal. Each staging of the modern must be arranged to produce the unified, global history of modernity, yet each requires those forms of difference that introduce the possibility of a discrepancy, that return to undermine its unity and identity. Modernity then becomes the unsuitable yet unavoidable name for all those discrepant histories" (Mitchell, 2000: 24; destaques meus). 
É relevante apontar, mais uma vez, que esta reorientação teórica não é um projeto original, uma espécie de mata virgem anti-eurocêntrica ainda a ser desbravada. Creio, pelo contrário, que uma série de formulações teóricas advindas de tradições diversas (e, sobretudo, da tradição marxista e dos estudos póscoloniais), críticas ao paradigma eurocêntrico da modernidade, permitem que se aponte para uma teoria crítica da modernidade global - modernidade vista como uma totalidade, esta definida pelas inter-relações de suas unidades; estas são, também, totalidades, ao mesmo tempo em que são parcialidades da totalidade maior $^{72}$.

Essa consideração da unidade dialética entre a modernidade e suas múltiplas manifestações abre caminhos para que estas sejam encaradas em sua dignidade histórica; ao mesmo tempo, ela convida a uma consideração da modernidade que possa incorporar a sua própria crítica, a partir da periferia - ou seja, ela fornece o solo para uma teoria crítica da modernidade periférica que seja, ao mesmo tempo, uma teoria crítica da modernidade. Um programa crítico deste tipo tentaria tirar as maiores conseqüências de uma consideração como a de Marx, de que a "colônia revela as entranhas da metrópole". Em uma proposta de pesquisa próxima à que aqui se apresenta, Boaventura de Sousa Santos (2004: 19), em diálogo com os estudos pós-coloniais, propõe um posicionamento "...nas margens ou periferias mais extremas da modernidade ocidental para daí lançar um novo olhar crítico sobre ela".

Portanto, não se trata exclusivamente de uma questão de acuidade científica, mas, igualmente, de uma tentativa de pensar criticamente a condição periférica e, a partir dela, a modernidade. Seguindo as instigantes sugestões de Paulo Arantes, parece-me que o "atraso" (ou a condição periférica) pode conduzir a novas formas de pensar e ser revelador de processos sociais que estão além dele mesmo (Arantes, 1992 e 1996; ver também Mignolo, 2003 e Santos, 2004). A periferia,

72 Esta formulação é inspirada, sobretudo, em duas fontes: a descrição de Paulo Freire sobre a constituição do sistema da Pedagogia do Oprimido (Freire, 2007: 135) e a definição do conceito de totalidade em Hegel fornecido por Martin Jay. Cito este trecho, bastante elucidativo: "...by employing the term 'totality' to refer to all coherent entities within the cosmic whole, Hegel encouraged the vision that lesser or partial totalities existed on all levels of the meta-totality. This acceptance of what we have called 'latitudinal totalities' meant that any part in a larger whole might itself be considered an organized whole from the perspective of its internal dynamics. Thus reality for Hegel was populated by multitudes of hierarchically linked or horizontally juxtaposed totalities, which defied comprehension through reduction to their component parts" (Jay, 1984: 59). 
dessa maneira, pode servir como lugar de onde parte a crítica de toda a modernidade, não mais como o outro dessa modernidade, mas como parte dela mesma. Essa espécie de reorientação da perspectiva da história mundial a partir da qual é narrada a história da modernidade em suas várias manifestações não deve servir, entretanto, a um projeto de justificação do pretenso atraso e de todas as formas de mazelas que acometem a periferia, mas, pelo contrário, como forma de entendê-los como partes do fenômeno da modernidade.

A seguir, tentarei desenvolver uma breve consideração sobre os possíveis diálogos teóricos que, a meu ver, podem ser trilhados em busca de respostas a esses problemas teóricos apontados. Acredito que esse movimento de constituição de uma teoria crítica da modernidade periférica deve passar por uma articulação de perspectivas teóricas diversas, que se propõem a falar a partir da periferia. Como sugiro anteriormente, considero, sobretudo, a possibilidade de um diálogo entre as teorias Pós-Coloniais e abordagens marxistas heterodoxas que se preocuparam em observar o caráter desigual do capitalismo global. Esse diálogo deve servir para o encaminhamento de uma consideração sobre as formas de dominação material e simbólica mundiais, ou seja, sobre as dinâmicas entrelaçadas de um capitalismo e uma modernidade globais e de suas formas de realização particulares.

A partir desse diálogo, buscaremos examinar como essas perspectivas realizaram três movimentos teóricos: 1) Dialética entre universal e particular na realização da modernidade em sociedades periféricas; 2) Compreensão da dinâmica interna dessas sociedades a partir de um ponto de vista da totalidade, possibilitando a superação da cisão interna entre atraso e moderno; 3) Avanço de uma consideração sobre o "ponto de vista" periférico como base de elaboração de perspectivas críticas sobre a modernidade.

Esse programa de aproximação entre perspectivas marxistas (ou inspiradas no marxismo, que se esforcem por compreender as dinâmicas mundiais do capitalismo) e teorias pós-coloniais já vem sendo proposto por diversos autores, apesar de ser um trabalho ainda em andamento (ver p. ex., Bartolovich, 2005; Bartolovich e Lazarus, 2002; Amadeo e Rojas, 2007). Amadeo e Rojas sintetizam esse programa teórico de forma bastante adequada: 
"Somente uma rearticulação da teoria pós-colonial com a teoria do sistema-mundo pode começar a reconstruir uma teoria crítica da globalização e do sistema de dominação mundial. Mas esta rearticulação deveria incluir os aportes que um conjunto de autores decisivos do pensamento crítico do século XX (Lukács, Sartre, Merleau-Ponty, a Escola de Frankfurt, Jameson, entre outros) têm feito à relação conflitiva entre particularidade e totalidade, que resulta um elemento central para a análise de um mundo como o atual, desgarrado pela tensão entre um falso universalismo determinado pela mundialização capitalista e uns particularismos (nacionais, culturais, étnico-religiosos e sociais) que não por "imaginários" (no sentido de Benedict Anderson) tem menos efeitos materiais sobre a configuração deste mundo" (Amadeo e Rojas, 2007: 13).

Diferentemente do que expressam teóricos pós-coloniais como Robert Young (1990) ou mesmo o primeiro Edward Said (2003), creio que a tradição marxista, a começar do próprio Marx, é indispensável pela a elaboração de uma reflexão póscolonial - mesmo sendo válidas as críticas às diversas passagens eurocêntricas em seu pensamento, em parte destacadas no capítulo 1. Como aponta George Steinmetz (2006: 6), a crítica desses autores - que não deve ser desprezada, mas contextualizada - centra-se em apenas uma pequena parte de seu trabalho - em geral no artigo de 1853, "The British Rule in India" e nas análises sobre o "Modo de Produção Asiático" - ignorando sua análise do caráter mundial do capitalismo ou, como já apontamos, a atenção que ele dedica, nos últimos anos de sua vida, a sociedades periféricas. Tendo em mente as considerações apresentadas com relação ao conceito de Modo Asiático de Produção no capítulo 1, parece estar claro que, devido ao seu estatuto problemático e ao caráter complexo e cambiante da obra de Marx, o abandono desse conceito não implica, de forma alguma, o abandono de toda contribuição da obra daquele autor e da tradição marxista (para um desenvolvimento desse ponto, ver Bartolovich, 2005).

Por fim, esse movimento de diálogo teórico deve se dar de forma simultânea a uma reflexão sobre o pensamento social produzido em nações periféricas - em grande medida desenvolvido para dar conta da compreensão dos destinos da modernidade nessas sociedades. Sociedades essas que não foram "contempladas pelos clássicos", mas que - por isso ou apesar disso - esforçaram-se em lançar um 
olhar sobre si próprias e sobre o mundo a partir de suas experiências de modernidade.

Descrevo brevemente os três pontos destacados acima no restante desse capítulo. Não se trata de uma tentativa de síntese geral, mas de um esforço de aproximação e tensionamento entre essas contribuições diversas, a partir dos problemas de que tratamos até o momento Os pontos apresentados por essa literatura diversa servirão como base para a análise da literatura que, a meu ver, tenta oferecer respostas alternativas - e críticas - com relação à modernização e à modernidade no Brasil e nas sociedades árabes e muçulmanas.

Para além das Múltiplas Modernidades: diálogos teóricos por uma teoria crítica da modernidade a partir da periferia

Dialética entre universal e particular na realização da modernidade em sociedades periféricas

Ao longo deste trabalho, referi-me inúmeras vezes à tendência do pensamento eurocêntrico em encarar as histórias das sociedades como entidades isoladas, em geral com o objetivo de buscar elementos que determinassem "essencialmente" seus destinos históricos. Ou seja, a tradição sociológica eurocêntrica, como a descrevemos, segue de perto aquilo que, como trataremos em maiores detalhes à frente, Lukács definiu como sendo uma das características do pensamento burguês: a ênfase da reflexão se dá na constituição dos objetos como "mônadas", e não como "objetos em relação". Essa crítica lukácsiana é uma apropriação marxista peculiar das críticas hegelianas ao pensamento representativo, este sistematizado de forma mais sofisticada na filosofia kantiana.

Sinteticamente, vale ressaltar que uma das tarefas fundamentais da geração de pensadores de que Hegel faz parte era superar as dualidades do pensar, as antíteses rígidas, que encontravam forma mais acabada na filosofia de Kant. No desenvolvimento de sua "gramática filosófica", Hegel entende que a unidade mínima do pensar não é o objeto, mas a relação - não haveria, para ele, qualquer objeto que tivesse sentido interno, mas apenas "com relação a" outros objetos. 
Nesse pensamento da relação, proposto por Hegel, a idéia de causalidade direta perde espaço para uma idéia de reciprocidade: um objeto ou dado não causa o outro, mas é fundamento de sentido do outro enquanto tem o outro como fundamento de seu próprio sentido, na forma de uma determinação recíproca. Com isso, Hegel procura pensar o real a partir de unidades mais englobantes, por meio da constituição de identidades restauradas, uma vez que essas se constituem em relação. Com essas novas identidades restauradas, Hegel pode pensar a diferença como algo interno ao ser, já que este se dá em relação.

Essas questões, a princípio bastante abstratos, foram fundamentais para inúmeras correntes críticas do pensamento social no século XX. Elas fornecem pontos de partida filosóficos, em particular, para uma série de autores que tentaram avançar uma crítica a formas diversas daquele pensamento eurocêntrico, muitos deles buscando superar a lógica dualista aplicada ao estudo do desenvolvimento capitalista em sociedades periféricas. Um grande exemplo deste tipo de reflexão está presente nos textos de cunho mais teóricos dos estudos da dependência. Grande parte desses estudos foram escritos ao longo das décadas de 1960 e 1970, principalmente por teóricos latino-americanos ${ }^{73}$.

No interior dessas reflexões, creio que são dignas de especial atenção para uma reflexão teórico-metodológica atual as obras de Fernando Henrique Cardoso (1975, 1977 e 1979) desenvolvidas após a publicação de Dependência e Desenvolvimento na América Latina (Cardoso e Faletto, 2004). Nesses trabalhos, Cardoso busca desenvolver uma análise dialética do processo de desenvolvimento dos países periféricos, a partir de um detalhado tratamento teórico das relações entre dinâmicas sociais e econômicas internas e externas. Considero que a análise de Cardoso sobre o capitalismo global e a dinâmica social nos países periféricos fornece um modelo inspirador, de grande sofisticação teórica, para uma consideração da modernidade e de sua realização nessas sociedades periféricas. Nos termos colocados acima, essa análise dialética da dependência não constitui uma nova forma de dualismo, mas sim um pensamento da relação. No interior dessa reflexão, o centro não constituiu a periferia, mas ambos se constituem

\footnotetext{
${ }^{73}$ Não poderei tratar aqui da diversidade dos debates no interior dos chamados "Estudos da Dependência" ou "Teoria da Dependência". Remeto, para isso, ao trabalho de Joseph Love (1998) e à análise crítica de Cardoso (1977). No capítulo 4, tratarei de parte do ambiente intelectual brasileiro em que alguns desses estudos foram desenvolvidos.
} 
mutuamente - o capitalismo mundial sendo, dessa forma, aquela unidade reinstaurada, internamente diversa.

A meu ver, a idéia fundamental é que a modernidade se constitui e reconstitui globalmente, a partir das disputas internas e externas a cada uma dessas sociedades. O seguinte trecho parece esclarecedor:

“... a dinâmica interna dos países dependentes é um aspecto particular da dinâmica mais geral do mundo capitalista. Porém, essa 'dinâmica geral', não é um fator abstrato que produz efeitos concretos; ela existe por intermédio tanto dos modos singularizados de sua expressão na 'periferia do sistema', como pela maneira como o capitalismo internacional se articula. Essa 'unidade dialética' é que leva a recusar a distinção metafísica (isto é, que supõe uma separação estática) entre fatores externos e efeitos internos, e por conseqüência leva a recusar todo tipo de análise da dependência que se baseia nessa perspectiva" (Cardoso, 1979: 126).

É importante apontar que, ao contrário de vários teóricos pós-coloniais como, por exemplo, Bhabha (1998), teóricos recentes da modernidade colonialidade, como Walter Mignolo e Edgardo Lander, desenvolvem uma defesa dos estudos da dependência e de seu caráter de crítica teórica anti-eurocêntrica. Em uma das muitas passagens em que realiza essa defesa, Mignolo afirma que "Dependency theory was parallel to decolonization in Africa and Asia and suggested a course of action for Latin American countries some 150 years after their decolonization. World-system analysis operates from inside the system, while dependency theory was a response from the exteriority of the system-not the exterior but the exteriority" (Mignolo, 2002: 62). Lander, por sua vez, aponta com muita pertinência que o pensamento latino-americano nos anos 1960 e 1970 foi um rico caldeirão de idéias e esforços de renovação intelectual crítica, influenciado por movimentos progressistas de vários tipos e pelo processo de descolonização em curso, sobretudo na Ásia e na África. É nessa época que conceitos como os de dependência, colonialismo interno, pedagogia do oprimido, colonialismo intelectual, pesquisa participante e libertação passaram a circular intensamente, com amplas conseqüências intelectuais e políticas (Lander, 2000: 519). 
Creio que esse tipo de observação é de extrema importância, sobretudo por apontar a possibilidade de reabilitar o tipo de reflexão desenvolvida no interior dos estudos da dependência. Estes representaram uma espécie de esforço descolonial válido e necessário, além de extremamente influentes no panorama intelectual e político de seu tempo, sobretudo nas sociedades periféricas - além de plenamente complementares a uma série de estudos pós-coloniais recentes, sobretudo nesse esforço em desenvolver um novo conceito, crítico e global de modernidade.

Boaventura de Sousa Santos, em uma tentativa bastante eclética de elaborar uma abordagem pós-colonial das dinâmicas e movimentos sociais do que ele chama de "Sul global", afirma que "O Próspero interno faz com que a violência na América Latina assumisse muito mais vezes a forma de uma guerra civil do que a forma de uma Baía dos Porcos" (Santos, 2006: 214). Essa formulação de Boaventura é bastante pertinente não apenas para se pensar o processo de inserção das sociedades latino-americanas na modernidade capitalista, mas também das outras sociedades periféricas.

Essa ausência de distinção metafísica entre as dinâmicas sociais internas e os processos marcantes da modernidade capitalista global ajuda a avançar uma compreensão da modernidade em sociedades periféricas para além de um "internalismo" eurocêntrico ou de um externalismo que atribui ao "imperialismo" todas as desventuras dessas sociedades. A idéia de uma "não distinção metafísica entre fatores externos e efeitos internos" fornece um ritmo nada linear para o drama que o "Próspero" ocidental e os "Calibãs" desempenharam na história dessas sociedades. Não é por menos que a crítica ao pensamento eurocêntrico no pensamento de diversas sociedades periféricas centrou-se, em diversos casos como veremos com relação ao Brasil e ao Egito - na crítica a categorias como a de "burguesia nacional": camada social que, segundo uma narrativa hegemônica acerca da passagem ao moderno, deveria encarregar-se do processo de modernização dessas sociedades, atuando como uma espécie de camada protestante acumuladora/empreendedora, independente dos desideratos do capital internacional ou dos setores agro-exportadores retrógrados.

Uma terceira referência teórica que tem em mente esse mesmo tipo de reorientação é Anouar Abdel-Malek (1975). Pare ele, as dinâmicas sociais devem ser compreendidas em um quadro que extrapola os limites das civilizações ou dos estados. Nesse sentido, Abdel-Malek expõe o que seriam os "dois círculos da 
dialética social": a) o círculo da dialética social endógena (luta de classes e de grupos sociais no interior de uma mesma formação sócio-econômica nacional) e b) - círculo da dialética social exógena (nações, áreas culturais e civilizações). Segundo esse quadro apresentado por Abdel-Malek, o conteúdo da dialética social em cada um desses círculos é idêntico: "trata-se de exercer a hegemonia para assegurar a continuidade do estatuto do grupo a que se refere e para preservar a sua extensão" (Abdel-Malek, 1975: 40). Assim, esses dois círculos não seriam entidades autônomas, na conceituação do autor. Pelo contrário, eles seriam os dois pólos mutuamente constitutivos do binômio que estrutura a dialética social na época contemporânea.

De forma sintética, podemos perceber que todas essas propostas apresentadas propõem uma concentração analítica no sistema de relações entre as nações ou civilizações. Ou seja, esse tipo de proposta teórica, no limite, visa a redefinir a unidade da análise a partir da qual se concebe a modernidade: do estado-nação ou da civilização, a unidade passa a ser a totalidade das relações entre os componentes das diversas sociedades que compõem o moderno sistema mundo capitalista. Stuart Hall, por exemplo, ao refletir sobre o sentido do termo "pós-colonial", entende que um dos objetivos fundamentais dessa vertente de estudos críticos é exatamente reler a colonização como parte de um processo global essencialmente transnacional e transcultural, conduzindo à re-escritura diaspórica, descentrada e global de grandes narrativas, antes centradas em uma perspectiva nacional - ou seja, as histórias do colonizador e do colonizado não podem ser narradas como "entidades discretas". Nesse sentido, Hall afirma que a partir do contato colonial entre europeus e povos americanos, no final do século $X V$, não haveria algo como uma temporalidade européia exclusiva, homogênea e vazia (Hall, 1996: 249-251).

Com essa observação, Stuart Hall toca em um ponto fundamental para uma série de críticas à noção de temporalidade que orienta a construção dos discursos sociológicos eurocêntricos. Como observamos anteriormente, grande parte dos dispositivos organizadores dessa estrutura de atitudes e referências baseia-se em uma idéia de "não contemporaneidade do contemporâneo" - ou seja, fenômenos presentes e inter-relacionados são tratados de forma a alocá-los no tempo, de maneira a distanciá-los ou aproximá-los da experiência "moderna" presente. Dessa forma, uma série de fenômenos engendrados nos múltiplos processos interligados 
de modernização - como, por exemplo, o racismo pós-colonial - são descritos como experiências passadas, pré-modernas, signos do atraso. Homi Bhabha, em um influente trecho de O Local da Cultura, mostrou que mesmo teóricos europeus que realizaram críticas monumentais à modernidade, como Michel Foucault, mostramse, em alguns momentos de suas obras, reféns dessa "lógica do contemporâneo/não-contemporâneo". Segundo Bhabha (1998: 341-344), isso seria sobretudo visível na conceituação de Foucault do racismo nazista como um dispositivo arcaico, baseado na "simbologia do sangue", e não da política da sexualidade, como ele poderia imaginar, de acordo com uma lógica moderna de controle e extermínio. Para erigir esse raciocínio, continua Bhabha, Foucault teria de ignorar as experiências históricas das sociedades coloniais, que teriam servido como "campo de prova" para os discursos do darwinismo social, ao longo do período neo-colonial.

Com essa crítica, Bhabha alerta para a necessidade em se pensar em um conceito de modernidade (e uma noção de temporalidade global interligada) que não relegue as experiências coloniais a uma posição exterior. Cito parte de suas conclusões, dada a clareza e a pertinência dessa crítica:

\begin{abstract}
"O racismo dos impérios coloniais é, portanto [em raciocínios como os de Foucault, JHB], parte de uma encenação arcaica, um texto-sonho de uma forma de retroversão histórica que 'parecia confirmar sobre um palco global e moderno antigas concepções de poder e privilégio'... Esse momento de disjunção temporal, que seria crucial para se compreender a história colonial do racismo metropolitano contemporâneo no Ocidente, é colocado 'fora da história'... Esses relatos da modernidade do poder e da comunidade nacional tornam-se estranhamente sintomáticos no momento em que criam uma retórica da 'retroversão' para a emergência do racismo" (Bhabha, 1998: 343-344).
\end{abstract}

Todas essas contribuições elencadas acima propõem, mais uma vez, uma mudança de unidade de análise para a conceituação da modernidade, em sua diversidade. Em termos lógicos, essa mudança de unidade, proposta por teóricos como Cardoso, Sousa Santos, Abdel-Malek, Hall ou Bhabha corresponde, resumidamente, à passagem de uma consideração das sociedades como unidades 
discretas para uma análise do sistema de suas relações. O que se pode derivar dessas considerações é a possibilidade de se pensar a modernidade como unidade dialética entre o universal e as suas diversas realizações particulares, em relação umas com as outras.

Essa mudança de nível de análise requer uma reformulação das categorias que povoam as mais diversas teorias sociológicas da modernidade. Essa necessidade de "adaptação" das categorias sociológicas está presente na reflexão de uma série de teóricos sociais anti-eurocêntricos. Dipesh Chakrabarty, a quem já me referi no início do segundo capítulo, sintetiza o esforço dos historiadores subalternos indianos como voltado àquela espécie de adaptação teórica indispensável à reflexão sobre as sociedades periféricas que queira dar conta da especificidade de suas formações e da maneira como elas se enquadram em uma história global da modernidade ${ }^{74}$. Chakrabarty nos lembra, entretanto, que essa adaptação só faz sentido quando visa a desvelar o caráter eurocêntrico das narrativas hegemônicas da modernização, propondo uma nova forma de conceber a história global, a partir das margens do sistema-mundo moderno. Esse exercício corresponderia, na visão do autor, a uma "provincialização da Europa". Essa provincialização - que surge como um exercício de "desprovincialização" da história das sociedades periféricas - corresponde a um programa contínuo de reestruturação de aparatos teóricos e teorias gerais do moderno, a partir das múltiplas experiências periféricas da modernidade ${ }^{75}$.

74 Esse tipo de problema também será abordado por Florestan Fernandes, sobretudo durante a redação d'A Revolução Burguesa no Brasil (1975). Ele afirmaria, no início da década de 1970, que "a questão fundamental, que se coloca, é de adequação: aos fatos do capitalismo dependente; às transformações sofridas pelo capitalismo na era atual. Essa adequação, empiricamente possível e logicamente necessária, permite explorar os principais modelos de explicação aplicados ao estudo do capitalismo e do regime de classes no passado, respeitando-se a integridade do ponto de vista e da problemática inerentes a cada um deles" (Fernandes, 1972: 45; destaque meu).

${ }^{75}$ Ao refletir sobre os estudos pós-coloniais e subalternos (sobretudo sobre a obra de Chakrabarty), Mignolo fornece igualmente um impulso a nossos questionamentos. $O$ seguinte trecho sumariza os grandes problemas de que trata Mignolo: "Provincializar a Europa significa, em última análise, uma historiografia que, através da escrita e da intersecção de ambos os lados da modernidade (como o Terceiro Mundo contribui para a modernidade ao mesmo tempo que a modernidade produz o Terceiro Mundo, ou de forma equivalente, como interagem no interior da diferença colonial da modernidade), espacializa o tempo e evita grandes narrativas de transição, progresso, desenvolvimento e pontos de chegada" (Mignolo, 2003: 281). 
As considerações da escola dos subalternos indianos vêm inspirando uma série de análises entre autores críticos latino-americanos, como Walter Mignolo, Edgardo Lander e Aníbal Quijano. Nessa crescente onda de estudos - que, infelizmente, ainda não atingiram a atenção devida na academia brasileira -, são fundamentais, por exemplo, os recentes estudos de Mignolo sobre a "dupla consciência" do homem colonial e pós-colonial, derivada do próprio estatuto da colônia como modernidade e diferença - ou a questão da "diferença colonial", para utilizar a linguagem derridiana do autor (Mignolo, 2000 e 2003). Com essas observações, Mignolo reforça a idéia de que a modernidade tem uma gênese global - ou, nos termos em voga nesse debate, ela é desde o início "Modernidade/Colonialidade":

"The European Renaissance and New World were two fundamental anchors of the modern/colonial world held together by the complicity between the rhetoric of modernity and the logic of coloniality. From the sixteenth century on, they co-exist and co-depend as well on the formation of 'capitalism' as we know it today. As a matter of fact, the modern/colonial world cannot be conceived except as simultaneously capitalist. The logic of coloniality is, indeed, the implementation of capitalist appropriation of land, exploitation of labor and accumulation of wealth in fewer and fewer hands" (Mignolo, 2007: 477).

\section{Superação da cisão interna entre "atraso" e "moderno"}

Como sugeri em diversos pontos, uma das mutações mais comuns do discurso eurocêntrico é a análise das sociedades periféricas como entidades cindidas em regiões ou setores atrasados e modernos - o que chamamos no capítulo 1 de modelo dualista. Esse modelo é a conseqüência de uma espécie de "internalização do outro moderno": o moderno não é visto apenas como o Ocidente ou um país específico que serve como fim histórico, mas passa a ser representado por alguma região ou setor da sociedade periférica que teria realizado com sucesso essa "passagem" ao moderno. Dessa maneira, as múltiplas temporalidades da estrutura de referências eurocêntricas poderiam ser vista em operação no interior de uma 
mesma sociedade ou civilização. Esse tipo de reflexão é uma constante no pensamento social que trata das diversas sociedades periféricas, além de possuir ampla circulação social. Os exemplos não faltam: uma Itália (sociedade de "modernização tardia", considerada bastante atrasada para padrões europeus até, ao menos, a metade do século $X X)$ setentrional desenvolvida, racional e "mais européia" e uma Itália Meridional atrasada, camponesa e "mais mediterrânea"; um Brasil dividido em regiões presas ao passado e megalópoles hiper-modernas ${ }^{76}$, ou entre setores modernos e atrasados (como no "best-seller" já citado de Almeida, 2007); sociedades muçulmanas cindidas entre elites urbanas ocidentalizadas e grupos tradicionais tribais, ou entre países religiosas e uma Turquia que teria conquistado acesso quase completo ao panteão de estados modernos - o modelo parece se repetir à exaustão.

Essa talvez seja a forma atual mais influente e resistente desse discurso, apesar das críticas que, nas mais diferentes sociedades, foram feitas a esse modelo analítico. Em grande medida, a crítica ao pensamento eurocêntrico realizada por pensadores sociais, em sua maioria, oriundos de sociedades periféricas, teve de debruçar-se na elaboração de uma crítica aos modelos duais. Uma série de pensadores de grande importância, muitos dos quais buscando aprofundar as reflexões marxistas sobre as "revoluções capitalistas" em sociedades periféricas, foram responsáveis por apontar as insuficiências em se pensar a modernidade na periferia sem uma profunda consideração acerca das articulações entre atraso $e$ moderno que, inexoravelmente, se produzem ao longo desse processo. Participam desse esforço crítico contínuo teóricos como Trotsky, Gramsci, Florestan Fernandes e Samir Amin, para citar apenas alguns.

Creio que o que aproxima grande parte das críticas desses autores àquela estrutura dualista de reflexão é a análise dessas sociedades a partir de um ponto de vista da totalidade (interna, mas com articulações externas, como vimos). Ou seja, a crítica visa mostrar, por caminhos diferentes, que as cisões internas não são

\footnotetext{
${ }^{76}$ A famosa reação do historiador Lucien Febvre ao visitar o Brasil na década de 1950 é mais do que conhecida. Febvre considerou o país uma realidade extremamente excitante para um historiador, uma vez que aqui se poderiam ver homens vivendo lado a lado em diferentes períodos históricos - aqui, o passado ter-se-ia mantido intacto, em contato com as coisas presentes (ver Viotti da Costa, 1978: 178). Não parece ser muito diferente o tom, por exemplo, da imensa maioria dos trabalhos jornalísticos atuais que tratam das sociedades muçulmanas: a recente explosão do turismo e modernização técnica em Dubai, explorada por ricos e famosos de todo o mundo, fornece um irresistível convite para um sem número de análises dualistas.
} 
compreensíveis se tomadas em suas particularidades, mas apenas a partir de uma consideração histórica que ilumine as formas como, presentemente, articula-se esse sistema interno de relações - tendo-se em mente, além disso, as relações entre cada uma dessas regiões e setores com o "círculo dialético" externo, nos termos de Abdel-Malek.

Dessa maneira, a partir dessas múltiplas relações (abstrato nesta apresentação, mas bastante concretizado nas múltiplas análises históricas desses autores), tentaram-se avançar diversas análises críticas àquelas formas de "dicotomias sem dialética" (Brandão, 2007: 143-150) ou de "senso de contrastes, sem dialética" (Arantes, 1992: 26) que acometem a reflexão sobre as sociedades periféricas - em que a modernidade aparece ou como um outro, ou como uma "valorosa" exceção que foge à regra do atraso. Quanto a este aspecto, parece-me que as reflexões mais amplas e que permitem a melhor compreensão dos casos diversos de articulação concreta das múltiplas temporalidades são o conceito de desenvolvimento desigual e combinado, formulado originalmente por Trotsky, e a análise da "revolução passiva" e da "questão meridional" italianas, realizada por Antonio Gramsci.

Comento, muito brevemente, essas contribuições, como forma de clarear a discussão deste e do próximo capítulo. Michael Löwy, por exemplo, considera que o interesse pela teoria do desenvolvimento desigual e combinado justifica-se "não apenas por sua contribuição à reflexão sobre o imperialismo, mas também como uma das tentativas mais significativas de romper com o evolucionismo, a ideologia do progresso linear e o eurocentrismo" (Löwy, 1998: 73). Esse conceito se encontra ao longo de toda a obra de Trotsky: não há qualquer texto dele que o apresente sistematicamente, apesar de haver alguns de seus livros em que, certamente, sua influência é maior, como 1905 e A História da Revolução Russa ${ }^{77}$. Neste, a idéia recebe sua principal conceituação:

"A desigualdade do ritmo, que é a lei mais geral do processus histórico, evidencia-se com maior vigor e complexidade nos destinos dos países atrasados. Sob o chicote das necessidades externas, a vida retardatária vê-se na contingência de avançar aos saltos. Desta lei universal da

${ }_{77}^{77}$ Para uma história do conceito na obra de Trotsky, ver Knei-Paz (2001: capítulo 3). 
desigualdade dos ritmos decorre outra lei que por falta de denominação apropriada, chamaremos de lei do desenvolvimento combinado, que significa aproximação das diversas etapas, combinação das fases diferenciadas, amálgama das formas arcaicas com as mais modernas. Sem esta lei, tomada, bem entendido, em todo o seu conjunto material, é impossível compreender a história da Rússia, como em geral a de todos os países chamados à civilização em segunda, terceira ou décima linha" (Trotsky, 1977 [1930]: 25).

A idéia de "amálgama" é central para nossa argumentação e constitui, provavelmente, o ponto mais profícuo da análise de Trotsky ${ }^{78}$. Segundo essa idéia, o atraso não deve ser visto como uma barreira à assimilação e à adaptação de técnicas modernas de produção ou, de maneira mais extensa, de padrões de sociabilidade tidos como modernos. O progresso industrial não teria refutado 0 atraso russo, mas o teria complementado dialeticamente (Knei-Paz, 2001: 77). Por meio de uma consideração do caráter desigual e combinado do capitalismo, é possível avançar a crítica à tese da convergência, já esboçada pela perspectiva das múltiplas modernidades - o capitalismo não "cria um mundo à sua imagem". O processo global de expansão capitalista cria amálgamas únicos em cada uma das sociedades em que este vai progressivamente se instalando, de acordo com a posição internacional dessas sociedades, mas também com suas características sociais, econômicas e culturais. Como sugere Knei-Paz, "The conception of backwardness as Trotsky presents it was founded on the premiss that 'history does not repeat itself', that historical analogies, though useful, are limited and that the past of one part of the world transforms the future of another, that, consequently, the task of social analysis was to clarify the unique, albeit in relation to universal factors" (Knei-Ppaz, 2001: 99).

Como se vê, Trotsky tem em mente uma tarefa de reconstrução das categorias classicamente mobilizados pelo marxismo ortodoxo para a compreensão do desenvolvimento do capitalismo em sociedades de "modernização tardia". Trotsky

\footnotetext{
${ }^{78}$ Digo o mais profícuo porque, certamente, o raciocínio do pensador e revolucionário ainda está marcado por alguma concepção de linearidade histórica - a própria forma como ele utiliza as idéias de "atraso" e "moderno" podem atestar isso. Contudo, sua análise avança, particularmente, ao mostrar a especificidade da modernidade em sociedades periféricas, de maneira que pode ser aproveitado muito positivamente se lido em paralelo com as outras contribuições críticas que são apresentadas neste capítulo.
} 
tenta lançar um olhar sobre a diversidade das experiências de industrialização nessas sociedades, sobretudo a partir da história específica da Rússia. Esse tipo de passagem do particular para o geral também é muito próprio do pensamento de um outro autor fundamental na tradição marxista heterodoxa e um dos mais influentes pensadores marxistas nas últimas décadas. Antonio Gramsci, entre os inúmeros problemas de que tratou em sua obra, dedicou especial atenção à questão do desenvolvimento econômico, social e político na Itália desde sua unificação, o Risorgimento.

Evidentemente não seria apropriado entrar em todos os detalhes e nuances apresentados por Gramsci sobre a questão, sintetizados sobretudo em seu Caderno 19, elaborado ao longo dos anos de 1934 e 1935 (ver Gramsci, 2002, vol. 5). Sinteticamente, Gramsci descreve o processo de unificação italiana como uma espécie de revolução passiva, ou seja, uma espécie de revolução realizada pelo alto, sem um processo de transformação completa das relações sociais (como teria acontecido, pelo contrário, no exemplo clássico de revolução, a francesa) - ou seja, constituiu um processo de "revolução sem revolução" (ver Gramsci, 2002, vol. 5: 63). Nesse processo, o Partido Moderado teria exercido a hegemonia política sobre as principais forças sociais do país (sobretudo as forças urbanas do Norte), mas haveria igualmente dirigido o Partido da Ação (liderado por Garibaldi). Este não teria conseguido exercer a direção sobre as forças camponesas, ficando aquém do único tipo de movimentação que poderia levar a uma solução "jacobina" para a unificação nacional italiana. Em processos de "revolução passiva", a conciliação entre as diferentes frações das classes dominantes seria um recurso para afastar a participação das classes populares, na passagem para a "modernidade capitalista". Como aponta Coutinho, Gramsci não se refere à "revolução passiva" como uma espécie de "revolução frustrada" - o que seria incorrer em um raciocínio da "incompletude", a que já me referi inúmeras vezes. Ao contrário, a "revolução passiva" seria um tipo específico de revolução exitosa, "ainda que feita através de conciliações pelo alto e da exclusão do protagonismo popular" (Coutinho, 2000: s.p.).

O que nos é de especial interesse aqui é a análise que Gramsci desenvolve sobre as relações entre o Norte "desenvolvido" e o Sul "atrasado" da Itália, no interior desse processo de unificação. Essa é a uma questão crucial para Gramsci desde o período anterior à sua prisão, quando atuava como importante liderança do 
Partido Comunista Italiano. Um de seus textos políticos mais conhecidos é "Alguns temas da Questão Meridional”, escrito em outubro de 1926, no qual Gramsci estabelece vários dos problemas que serão desenvolvidos em seus cadernos durante seu período de cárcere, tendo em vista, fundamentalmente, a necessidade da união entre operários e camponeses para o avanço do processo revolucionário uma posição heterodoxa no interior do movimento comunista internacional, até algumas décadas depois ${ }^{79}$. Essas duas forças sociais, unidas, seriam as "portadoras do futuro", na visão do líder revolucionário (Gramsci, 1987: 165).

O que já é perceptível nesse texto é a tentativa de desenvolver uma análise das relações entre a Itália Setentrional e Meridional como caminho para a compreensão do desenvolvimento dessas duas regiões, em vez de tomá-las como realidades isoladas (ver Gramsci, 1987) - esta, uma perspectiva comum nas análises políticas e científicas das primeiras décadas do século XX. Essa postura teórica será desenvolvida de forma exemplar em suas análises do Risorgimento italiano, em que a consideração sobre a hegemonia do Norte sobre o Sul desempenha um papel fundamental:

"A 'miséria' do Mezzogiorno era 'inexplicável' historicamente para as massas populares do Norte; elas não compreendiam que a unidade não ocorrera numa base de igualdade, mas como hegemonia do Norte sobre o Mezzogiorno numa versão territorial da relação cidade-campo, isto é, que o Norte concretamente era um 'sanguessuga' que se enriquecia à custa do Sul e que seu desenvolvimento econômico-industrial estava em relação direta com o empobrecimento da economia e da agricultura meridional. Ao contrário, o homem do povo da Itália do Norte pensava que, se o Mezzogiorno não progredia depois de ser libertado dos entraves que 0 regime dos Bourbons opunha ao desenvolvimento moderno, isso significava que as causas da miséria não eram externas, a serem buscadas nas condições econômico-políticas objetivas, mas internas, inatas na população meridional, tanto mais que estava enraizada a conviç̧ão da riqueza natural da terra: e só restava uma explicação, a incapacidade orgânica

${ }^{79}$ Para o capítulo brasileiro dessa questão, ver o polêmico livro de Caio Prado Júnior, $A$ Revolução Brasileira, de 1966. 
dos homens, sua barbárie, sua incapacidade biológica" (Gramsci, 2002, vol. 5: 73-74) ${ }^{80}$.

É fundamental perceber como a solução apontada por Gramsci para o tratamento da "Questão Meridional" fundamenta-se em uma superação do dualismo, a partir de uma análise histórica que se orienta pela categoria da totalidade. Ela representa uma categoria lógica fundamental para compreender a funcionalidade do atraso nos processos de modernização ${ }^{81}$. Na seqüência da citação acima, Gramsci irá mostrar como a sociologia positivista italiana teria assumido a validade científica desses postulados acerca da inferioridade biológica ou intelectual dos homens do sul. Martin Jay indica que essa questão foi de extrema importância para o desenvolvimento de uma postura anti-positivista em Gramsci: resolver a "questão meridional" exigiria, antes de tudo, uma quebra com o positivismo em sua versão dualista (Jay, 1984: 154).

Além disso, o conceito de totalidade implícito nessa forma de resolução não se exaure na análise das relações internas ao estado-nação italiano; Gramsci insiste em diversas passagens que o contexto das disputas sociais nacionais é uma mera abstração se isolado dos seus nexos internacionais: "a personalidade nacional expressa uma 'especificação' do todo internacional, portanto está ligada às relações internacionais" (Gramsci, 2002, vol 5: 16). Gramsci alerta que as origens do Risorgimento e a solução das relações entre o norte e o sul da península a ele relacionadas só poderiam ser buscadas no processo histórico por meio do qual todo o sistema europeu se transforma, um processo indissociável com as disputas internas à Itália. Dessa maneira, Gramsci já coloca em operação aquilo que, posteriormente, Abdel-Malek trataria como a relação entre os "dois círculos da dialética social", ou a "não distinção metafísica entre interno e externo" alertada por Cardoso.

\footnotetext{
${ }^{80}$ Como aponta Gramsci a seguir, a conseqüência política desse dualismo é um tratamento da Itália meridional como uma espécie de "peso morto" para o país, e a convicção de que a Itália industrial do Norte faria maiores progressos sem ela - uma opinião que teria sido defendida em diversas ocasiões por personalidades políticas do Norte, no início do século XX (ver Gramsci, 2002, vol. 5: 74).

${ }^{81}$ Carlos Nelson Coutinho (1987), tentando demonstrar a amplitude das lições apresentadas por Gramsci, aproxima a "Questão Meridional" italiana da "Questão Nordestina" brasileira, destacando exatamente o problema da funcionalidade do atraso de determinadas regiões ao longo do processo de desenvolvimento de sociedades periféricas.
} 
Essas análises de Trotsky e Gramsci serviram de modelo para diversas análises de processos de modernização em sociedades periféricas. Os termos "revolução passiva" e "desenvolvimento desigual e combinado", por sintetizarem esse esforço crítico de busca da especificidade da modernização e da modernidade periféricas, tornaram-se quase sinônimos de "modernização capitalista" para os processos sociais relacionados à modernização nessas sociedades (ver, por exemplo, Arantes, 1992; Werneck Vianna, 1997; Oliveira, 1972; Amin, 1976; Gran, 1996). Essa busca pela articulação interna do que se convenciona chamar de "atraso" e "modernidade" marca, portanto, uma série de esforços de superação do dualismo - este, típico de uma mobilização específica de uma estrutura de atitudes e referências sociológicas eurocêntricas.

\section{Periferia como lócus de crítica da modernidade}

As duas breves considerações anteriores são fundamentais para que se tente avançar em um questionamento sobre a possibilidade de se entender a periferia ou, em outros termos, as sociedades periféricas - como pontos de crítica da modernidade. Esta é uma idéia bastante presente em uma série de trabalhos críticos ao pensamento eurocêntrico, constituindo, em muitos casos, a forma mesma de conceituar a essência de uma teoria pós-colonial ou descolonial. Nesse sentido, a partir da leitura de autores como Paul Gilroy, Boaventura de Sousa Santos ou Walter Mignolo, o exercício teórico pós-colonial não se referiria a um conjunto pré-determinado de conceitos ou à pré-delimitação de categorias e linhagens teóricas, mas constituiria o próprio exercício de reorientação do olhar para uma consideração da modernidade a partir de suas margens. Dessa maneira, percebe-se que, nessa diversidade de trabalhos, há a intenção de repensar a modernidade como uma realidade histórica global (desde sua gênese) e internamente diversa; nessa nova forma de ver a modernidade que se vai coletivamente formulando, a perspectiva histórica das sociedades periféricas forneceria o olhar a partir do qual se poderia avançar a crítica dessa modernidade ou dessa modernidade/colonialidade, mais precisamente.

Dito de outra maneira, e certamente correndo o risco de soar repetitivo, o que me parece que se está formulando coletivamente é a idéia política e epistemológica 
de um "ponto de vista" periférico: a periferia como lugar de onde parte a crítica de toda a modernidade, não mais como o outro dessa modernidade, mas como parte dela mesma, como já havia afirmado anteriormente. Nesse sentido, a idéia de que a modernidade deve ser encarada - em sua gênese e múltiplas manifestações como uma realidade global leva essa diversidade de trabalhos anti-eurocêntricos a postularem a possibilidade de pensar a periferia do capitalismo moderno como ponto privilegiado de crítica da modernidade - ou, mais precisamente, de uma crítica não eurocêntrica da modernidade.

É nesse sentido que se torna factível refletir sobre as possibilidades de se falar "a partir de" uma perspectiva política qualquer, já que esse tipo de reflexão marcou uma série de trabalhos críticos ao longo do século XX. Mais precisamente, essa idéia de um "conhecimento situado" da crítica à modernidade ou ao capitalismo é marca de diversos esforços críticos recentes nas Ciências Sociais e na Filosofia que passaram a influenciar uma parte importante da crítica Pós-Colonial Contemporânea.

É exemplar, nesse sentido, o esforço de uma série de pensadoras feministas, desenvolvido nas últimas três décadas, que buscaram refletir sobre o potencial de uma agenda de pesquisa que explore um "ponto de vista feminista" (feminist standpoint) como perspectiva política e científica (ver, p. ex. Harding, 1998). Tratase, sem sombra de dúvidas, de um projeto anti-objetivista, que defende que problemas políticos e científicos são sempre problemas para alguém (ver Harding, 1987: introduction); contudo, como apontam essas autoras, a defesa de conhecimentos situados não corresponderia a uma posição relativista: pelo contrário, elas propõem uma mudança na própria concepção da função social e da forma de operação do conhecimento científico, para que este se volte crucialmente para a crítica e a transformação das formas de dominação vigentes. Nancy Hartsock, por exemplo, descreve a epistemologia feminista como uma visão engajada, advinda de uma posição de opressão, com vistas a expor as relações reais entre os seres humanos como desumanas, podendo assumir, dessa forma, um papel histórico emancipatório (Hartsock, 1987: 160) ${ }^{82}$.

82 Como se pode imaginar, essas autoras foram acusadas de proporem uma visão epistemológica essencialista, como se o mundo estivesse de imediato aberto ao conhecimento para as mulheres, apenas pelo fato de serem mulheres (e oprimidas). A essas críticas essas autoras tentaram responder fundamentalmente de duas formas: 1) o ponto de vista feminista, como aquele que desvela uma opressão específica, não seria 
Evidentemente, a inspiração inicial dessas autoras foram, de um lado, as obras que desenvolveram a perspectiva de conflito social e da tomada de consciência presente na dialética do Senhor e do Escravo, proposta por Hegel na Fenomenologia do Espírito ${ }^{83}$; de outro lado, o trabalho fundamental de Georg Lukács, História e Consciência de Classe. Esta obra seminal do pensamento crítico do século XX busca, entre suas tarefas, desenvolver uma defesa do "ponto de vista" do proletariado como aquele a partir do qual se poderia avançar uma crítica às antinomias do "pensamento burguês", assim como fornecer as bases para a ação transformadora real da sociedade. O ponto de vista do proletariado seria o único que, num processo histórico de tomada de consciência, poderia realizar a crítica da totalidade das relações sociais próprias à sociedade capitalista (ver Lukács, 2003).

É interessante - e não se trata de nenhum acaso, por certo - perceber que Lukács desenvolve uma crítica ao "pensamento burguês" bastante semelhante, em diversos aspectos, às críticas que parte dos teóricos da dependência endereçaram às teorias da modernização ou que teóricos pós-coloniais vêm endereçando às teorias orientalistas ou eurocêntricas. Lukács aponta, por exemplo, que o pensamento burguês considera os fenômenos sociais em sua "unicidade isolada", em sua objetividade de puro fato; ele faz do objeto histórico tratado uma "mônada imutável excluída de toda interação com outras mônadas", "à qual as características que ela possui em sua existência imediata parecem estar ligadas como propriedades essenciais simplesmente insuperáveis" (Lukács, 2003: 315). Essa sua crítica encontra bastante paralelo (apesar de ser elaborada de forma e com objetivos não idênticos) à crítica ao tratamento das sociedades não ocidentais ou periféricas desconectada da história das outras sociedades e da modernidade capitalista, como já vimos anteriormente. Lukács sugere que "para poder compreender a mudança, o pensamento deve superar a separação rígida dos seus objetos; deve colocar as suas inter-relações e a interação dessas 'relações' e das 'coisas' no mesmo plano de realidade" (Lukács, 2003: 316). Lukács aponta ainda que o pensamento burguês, ao aceitar as formas secundárias da objetividade e

apenas acessível a mulheres, mas também a homens que compartilhassem dessa luta (ver Harding, 1987); 2) o conhecimento a partir desse ponto de vista não seria imediato, mas adviria de um processo de disputa, tanto científica quanto política - a ciência, dessa forma, sendo vista como um campo de batalha interligado às disputas sociais dos diversos grupos oprimidos (Hartsock, 1987: 162; Harding, 1987).

${ }^{83}$ Obras que, em geral, se relacionam à tradição francófona de recepção da obra de Hegel, via as leituras de Alexander Kojève - tradição de que fazem parte pensadores como Sartre, Simone de Beauvoir e Frantz Fanon. 
proceder a uma auto-supressão da história, é fundamentalmente antinômico funda-se em antinomias do tipo subjetividade-objetividade, liberdade-necessidade, indivíduo-sociedade, forma-conteúdo. A crítica às antinomias do pensamento burguês foi inspiradora (sobretudo entre os sociólogos que, de alguma forma, se aproximaram dos estudos da dependência, como veremos melhor no capítulo seguinte) de uma forma de superar a cisão atraso-moderno própria das várias formas do pensamento eurocêntrico.

O que ainda vale apontar, de forma bastante simplificada, é que Lukács tentou avançar a idéia de que o ponto de vista do proletariado seria objetivamente superior. Não entrarei aqui no mérito do complexo desenvolvimento dessa idéia nesse autor e no pensamento marxista do século XX (para uma análise dessa questão, ver Löwy, 2007). O que é importante destacar é que, em Lukács, já há uma primeira consideração a respeito de uma perspectiva política e epistemológica que privilegia conhecimentos situados, a partir dos quais seria possível conhecer e realizar a crítica da totalidade das relações sociais. Assim, seja de uma perspectiva proletária ou feminista, a idéia de uma epistemologia que privilegia loci de fala subalternos é característica de esforços em se pensar criticamente situações sociais de dominação específicas, a partir das perspectivas daqueles que se encontram subjugados nessas situações.

Creio que essa perspectiva epistemológica é de bastante valia na aproximação de diversas perspectivas teóricas que trataram dos processos assimétricos do capitalismo e as formas de dominação próprias à Modernidade/Colonialidade - como vêm se referindo diversos autores críticos latino-americanos. Neste caso, evidentemente, trata-se de pensar a especificidade de uma posição coletiva geo-histórica como fundamento possível de crítica à modernidade - posição essa ocupada pelas sociedades periféricas e, particularmente, pelas suas camadas subalternas. Em síntese, creio que o que mais aproxima perspectivas pós-coloniais e subalternas recentes e trabalhos de crítica anti-eurocêntrica desenvolvidas há algumas décadas - como os estudos da dependência - é exatamente uma agenda intelectual centrada na idéia de um "ponto de vista periférico" a partir do qual uma crítica da modernidade global pode ser avançada; dito de outra forma, proponho que essa articulação aponta para uma crítica "pós-colonial" da modernidade global como um esforço aberto e inter- 
paradigmático de formulação de conhecimentos situados a respeito da modernidade global.

Nesse sentido, o "pós-colonial" pode ser visto não como mais uma escola crítica das Ciências Sociais, mas como um ponto de vista político e epistemológico a partir do qual uma teoria crítica da modernidade periférica (como momento de uma teoria crítica da modernidade global) poderia ser dialogicamente avançada. Enfatizo aqui a idéia de que se trata de um "momento", uma vez que essa perspectiva pós-colonial, como vem sendo avançada nos principais trabalhos recentes, não exclui ou abre mão de outras perspectivas críticas da modernidade como, por exemplo, os trabalhos pós-estruturalistas ou frankfurtianos - mas os complementa, a partir da crítica à colonialidade da modernidade ${ }^{84}$. Repito a citação de Abdel-Malek, pela sua precisão: "a hegemonia das minorias possuidoras revelada por Marx e Engels e o antropocentrismo desmantelado por Freud seguem de mãos dadas com o eurocentrismo nas Ciências Humanas e Sociais, principalmente naquelas que têm relação direta com os povos não-europeus" (citado em Wallerstein, 2007: 68).

Creio que essa postura ajuda a solucionar vários questionamentos que foram colocados aos teóricos pós-coloniais acerca de suas relações com o pensamento marxista e pós-estruturalista e as possibilidades de integrá-los, ou sobre a delimitação temporal da "pós-colonialidade" (ver Hall, 1996; Appiah, 2003; Ahmad, 2002). Encarar a perspectiva pós-colonial a partir de uma idéia de ponto de vista crítico à modernidade, lançado a partir da história de sua periferia, permite que aportes teóricos de tradições diferentes possam integrar seus aparatos críticos, sem que haja uma inadequação a priori. É importante ainda perceber que essas formas específicas de pensamento de resistência, simbolizadas pela obra de pensadores como Frantz Fanon, Abdel-Malek, Albert Memmi, Aníbal Quijano e C.L.R. James só pode ser lida tendo-se em mente as longas lutas de descolonização travadas ao longo do século XX e as disputas por projetos sociais no interior dessas sociedades.

${ }^{84}$ Gilroy, por exemplo, mostra como o pensamento negro militante, base para suas propostas teóricas de reorientação do nível de análise da modernidade, desenvolveu-se em permanente diálogo com pensadores da diáspora judaica. Além disso, ele aponta como o pensamento de um pensador contemporâneo como Zygmunt Bauman pode ser de grande interesse para uma reflexão acerca da cumplicidade entre racionalidade moderna e terror racial, ou seja, para um pensamento anti-racista e anti-eurocêntrico - mesmo sem que aquele autor trate fundamentalmente dos problemas do racismo advindos do processo de colonialismo europeu (ver Gilroy, 2001: 397). 
Uma concepção interparadigmática e crítica que exemplifica essa definição de teoria pós-colonial ou descolonial é a que está em jogo com o uso da categoria "colonialidade do poder". A articulação de formas de opressão materiais e formas de conhecimento depreciativas - apontadas com mais ênfase pela tradição dos estudos da dependência e pós-coloniais, respectivamente - está em operação com a idéia de colonialidade do poder, na forma como ela vem sendo apresentada por teóricos críticos latino-americanos contemporâneos, no interior e em continuidade com uma série de formulações críticas ao eurocentrismo que marcaram a reflexão de intelectuais - sobretudo advindos de sociedades periféricas - ao longo das últimas décadas. Os teóricos da modernidade/colonialidade - como Walter Mignolo, Enrique Dussel e Aníbal Quijano - buscam compreender o caráter intrínseco entre o desenvolvimento da modernidade e a colonialidade do saber e do poder. Dussel aponta que, de início, os descobrimentos e a conquista são de fundamental importância para o desenvolvimento do "ego" europeu moderno (Dussel, 2000: 22). Essa forma de tratar o surgimento da modernidade é uma dura resposta a aspectos importantes do pensamento de teóricos como Hegel e, mais recentemente, Habermas, que, como vimos, tenderam a identificar o surgimento da modernidade com eventos "próprios à Europa" - como se a erupção desses aí não dependesse de uma história mundial e, em segundo lugar, como se eles não fizessem parte de uma história mundial intrinsecamente marcada pela assimetria de poder.

A definição dos descobrimentos e das conquistas coloniais a partir do século $\mathrm{XVI}$ como pontos de início da modernidade traz conseqüências fundamentais para uma elaboração de sua crítica, exatamente por desvelar e colocar em primeiro plano as diversas formas de violência geradoras e mantenedoras dessa modernidade e por descrevê-la como um fenômeno global, desde sua "gestação" primeira.

O caráter gerador da articulação entre a Europa e a periferia do sistemamundo moderno não se restringe apenas à identidade do eu europeu moderno, mas igualmente à gestação dos dispositivos sociais e organizativos que viriam a ser fundamentais para o estabelecimento da "moderna sociedade de controle" - com seus dispositivos de poder, conhecimento e personalidade analisados de forma mais marcante por Foucault (1977 e 2007) - e para a racionalização da produção na Europa da Revolução Industrial. Mitchell, mesmo sem mobilizar a idéia de modernidade/colonialidade, tenta sintetizar essa diversidade de novos estudos que 
buscam mostrar as origens relacionais da modernidade européia. Uma série de estudos recentes vêm mostrando, por exemplo, a importância dos engenhos de cana-de-açúcar movidos a trabalho escravo, nas Antilhas e no Brasil, para o desenvolvimento das modernas técnicas de gestão e controle do trabalho no interior da fábrica (ver Mitchell, 2000: 8).

Esses estudos apresentados por Mitchell vêm ampliando a idéia de que a colonização teria um caráter fundante do capitalismo "europeu", levando essa questão para além da consideração marxista acerca do papel das colônias na "acumulação primitiva de capital". A violência inaugural do capitalismo, classicamente analisada por Marx, ganha um aspecto mais abrangente e preciso quando se leva em consideração todas aquelas outras formas de acumulação que vão se constituindo ao longo da Idade Moderna nas relações entre as metrópoles ocidentais e suas colônias. Como diria Dussel, a primeira experiência moderna teria sido o enfrentamento entre conquistador e conquistado: "a colonização da vida cotidiana do índio, do escravo africano pouco depois, foi o primeiro passo 'europeu' de 'modernização' da civilização, de subsumir (ou alienar) o outro como 'si mesmo'” (Dussel, 2000: 47). No limite, críticas como a de Dussel se recusam a encarar a modernidade como um "projeto ocidental" incompleto: o filósofo afirma que a modernidade se comporia de um conceito emancipador racional e de um mito irracional, justificador da violência, sendo a função de uma teoria crítica antieurocêntrica o desvelamento e a crítica a esse mito (Dussel, 2000: 7).

Um movimento parecido com esse é realizado por Paul Gilroy. Esse autor, em seu importante livro O Atlântico Negro, elege como marco inicial da modernidade a subida do primeiro africano em um navio negreiro para ser transportado rumo ao exercício da colonização européia nas Américas. Essa proposta de Gilroy, mais do que uma mera provocação, estabelece o "Atlântico Negro" como uma unidade transnacional e transcultural de análise da modernidade, em substituição à perspectiva nacional própria da estrutura de referências eurocêntricas. Como nos sugere Gilroy:

"Subir a bordo, por assim dizer, oferece um meio para reconceituar a relação ortodoxa entre a modernidade e o que é tomado como sua pré-história. Fornece um sentido diferente de onde se poderia pensar o início da modernidade 
em si mesma nas suas relações constitutivas com estrangeiros, que fundam e, ao mesmo tempo, moderam um sentido auto-consciente de civilização ocidental" (Gilroy, 2001: 61).

O que esses autores estão propondo é que a modernidade não seja conceituada como um "projeto" europeu universalizável, realizado com maior ou menor êxito em determinadas regiões ou épocas, mas um processo global e assimétrico, visto a partir de suas partes menos favorecidas. Gilroy, particularmente, esboça um projeto em que as memórias da escravidão serviriam como recurso para se indagarem as bases da filosofia e do pensamento modernos. Contrariamente às crenças nas promessas irrealizadas da modernidade, Gilroy chama a atenção para a história da diáspora africana como uma das formas de reavaliar o papel da escravidão e da colonialidade na construção da modernidade. (ver Gilroy, 2001: 99; Mignolo, 2003: capítulo 2).

Como diz Bhabha, "A crítica pós-colonial é testemunha das forças desiguais e irregulares de representação cultural envolvidas na competição pela autoridade política e social dentro da ordem do mundo moderno" (Bhabha, 1998: 239). É nesse sentido que o "pós-colonial" não se refere apenas (e fundamentalmente) a um período. Como diz Hall (1996: 253), esse pós tem, sobretudo, um sentido de para além de, em um campo de forças do poder-conhecimento. Um esforço de superação, dessa forma, articulado a partir da perspectiva das sociedades e povos periféricos - a exterioridade (não o exterior) da modernidade.

Esse "campo de forças do poder-conhecimento" não se instaurou apenas quando os intelectuais do terceiro mundo passaram a produzir na academia anglosaxã, formulando teorias tributárias do alto-humanismo ocidental - como expressam algumas das mais conhecidas críticas ao programa pós-colonial (ver Dirlik, 2003). Esse campo de forças é uma arena de grande relevância na história intelectual de todas as nações periféricas e pós-coloniais. As formas e categorias do pensar eurocêntrico fornecem receitas diversas para a reflexão sobre o passado e sobre os destinos dessas sociedades, como já vimos. Por outro lado, em diversos contextos periféricos, foram-se constituindo perspectivas analíticas críticas àquele paradigma. Perspectivas que, em muitos casos, expressavam um descontentamento intelectual 
e político com as perguntas e respostas formuladas (e formuláveis) no interior daquela estrutura de referências eurocêntricas.

Uma tarefa fundamental de qualquer esforço de descolonização epistêmica é examinar essa diversidade de vozes locais e sua contribuição para uma reflexão sobre a modernidade, a partir da periferia. A reflexão sobre elementos do "atraso" nessas sociedades a partir da consideração sobre o caráter mundial da modernidade ilumina a idéia de que esta é também, desde seu início, colonialidade.

Tendo estes problemas em vista, apresentarei nos dois capítulos seguintes alguns desses esforços de constituição de leituras anti-eurocêntricas da modernidade, nas sociedades muçulmanas e no Brasil. O objetivo não é, mais uma vez, analisar obras em profundidade ou sistematizar todas as possíveis vozes insurgentes nesses exercícios pós-coloniais locais, mas observar como alguns autores e tradições deram respostas alternativas e críticas aos dilemas colocados pelos discursos eurocêntricos. Com isso, procuro demonstrar que diversos problemas sintetizados de forma teórica neste capítulo estão em jogo, há décadas, em uma série de interpretações históricas e sociológicas acerca da modernidade, em cada uma dessas sociedades. 


\section{As sociedades árabes e muçulmanas: modernidade periférica como simbiose do arcaico e do moderno}

O resultado, conscientemente perseguido pelo colonialismo, era pôr na cabeça dos indígenas que a partida do colono significaria para eles a volta da barbárie, a degradação, a animalização. No plano do inconsciente, o colonialismo não procurava pois ser percebido pelo indígena como uma mãe gentil $e$ benevolente, que protege a criança contra um ambiente hostil, mas sob a forma de uma mãe que, continuamente, impede o filho fundamentalmente perverso de suicidarse, de dar livre curso aos seus instintos maléficos.

Frantz Fanon (2005 [1961]: 244)

De que maneira pode-se dizer que as sociedades árabes e muçulmanas apresentam uma especificidade, que são distintas de todas as outras? Ou que os problemas ali encontrados não podem ser entendidos a partir dos mesmos procedimentos e categorias utilizados para a compreensão de outras sociedades do mundo? Como já vimos, a estrutura de referências eurocêntricas, em suas múltiplas manifestações, destaca exatamente o caráter "excepcional", "aberrante" das sociedades e estados da região. Pode-se observar "pelo negativo" uma outra manifestação dessa postura intelectual: é notável a pouca consideração dedicada a sociedades árabes e muçulmanas em recentes estudos comparados sobre democratização ou sobre estruturas e dinâmicas sociais de países periféricos. Tal constatação, em geral levantada por especialistas na região, reforça aquela idéia presente em boa parte da academia e entre lideranças políticas ocidentais de que a região constitui objeto sui generis, excepcional, não podendo ser alvo de uma reflexão histórica ou teórica comparativa (Halliday, 2003; Hudson, 2001; Ross, 2001). Excepcionalidade, em geral, acompanhada por uma forte imagem de exotismo.

Fred Halliday fornece uma consideração bastante interessante a respeito do "particularismo" no tratamento das sociedades árabes e muçulmanas. Halliday distingue entre um particularismo analítico e um particularismo histórico. De acordo com a primeira postura, as categorias usadas para descrever essas sociedades devem ser específicas para essa região - exemplo dessa postura é o nacionalista que rejeita por completo a sociologia de Weber e Marx em nome de conceitos 
autenticamente nacionais ou islâmicos, ou em nome de alguma forma modificada do pensamento de Ibn Khaldun, por exemplo. Já de acordo com um postulado de particularismo histórico, as especificidades do Oriente Médio podem apenas ser compreendidas à luz da consideração sobre a formação histórica dessas sociedades: "In terms of this second particularism the Middle East is peculiar, not because the categories of analysis applicable elsewhere do not apply, but because of the specific processes of historical formation through which Middle Eastern states have passed" (Halliday, 2003: 15). Essa consideração de Halliday, que poderia ser estendida a qualquer outra sociedade ou conjunto de sociedades, parece estar em grande acordo com a consideração sobre as modernidades periféricas que, até o momento, tentou-se aqui avançar.

O Oriente Médio e, mais especificamente, os países árabes e muçulmanos vêm sendo normalmente descritos como a principal região do mundo a não fazer parte da chamada "Terceira Onda de Democratização" - título dado aos processos políticos observados por alguns analistas em diversas regiões do mundo em desenvolvimento e do Leste Europeu ao longo das últimas três décadas e que, segundo muitos analistas, levaria à instalação de democracias liberais nesses estados (Huntington, 1991). A tese sobre a "Terceira Onda" - aliada a outras teorias que apregoam a inevitabilidade histórica da instalação de democracias liberais em todos os cantos do mundo, cuja representante maior é a famigerada tese do "fim da história", de Francis Fukuyama (1989) - marcou tanto a política das grandes potências ocidentais quanto a produção acadêmica sobre regimes políticos e democratização. Uma grande quantidade de trabalhos, sobretudo de cientistas políticos, passou a concentrar-se nos processos de "transição" em países em desenvolvimento e em ex-estados socialistas. Esses encaminhamentos acadêmicos, aliados ao imaginário político tão em voga com o fim da Guerra Fria, afastaram as sociedades árabes e muçulmanas do centro do debate sobre a política nos países em desenvolvimento, lugar que antes havia ocupado, junto da América Latina e de alguns estados asiáticos.

Essas sociedades, segundo essa análise, continuariam como estranhas (um "outro", mais uma vez) aos processos políticos mais fundamentais que teriam marcado a época recente. Na maioria dessas sociedades, o processo de liberalização política, iniciada em alguns países (como Egito, Jordânia e Líbano), 
havia sido paralisado, se não revertido; nenhum líder autoritário havia sido removido por meio de eleições competitivas (Posusney, 2004).

Apesar da constatação de que, atualmente, todos os Estados árabes possuam regimes autoritários ou, no máximo, em processo de abertura política, é preciso salientar que não há uma completa uniformidade entre eles - ou seja, não há algo próximo a um modelo bem definido de autoritarismo árabe. Contudo, é possível observar a existência de dois tipos fundamentais de regimes autoritários na região: as chamadas "ditaduras de partido único" e as "monarquias autoritárias" (ou regimes de controle familiar) (ver Owen, 1992; Brumberg, 2002). No interior desses casos há, evidentemente, importantes variações. O Marrocos e a Jordânia, por exemplo, constituem monarquias que, apesar de ainda manterem um domínio exclusivo familiar-real, passaram por recentes processos de abertura política que permitiram a entrada em jogo de forças internas de oposição. Além desses, o Líbano e o Iraque atuais oferecem difíceis obstáculos à análise e à classificação: o Líbano possui um regime parlamentar, com amplos direitos civis concedidos à população e com eleições freqüentes, apesar da manutenção de uma divisão de poder interna entre as comunidades religiosas que constituem o país; o Iraque, por sua vez, está longe de poder ser considerado uma democracia no período posterior à invasão norte-americana e à sua pretensa tentativa de implantação de um regime democrático, apresentando hoje um quadro de violência e caos político e social que tornam impossível qualquer tipo de avaliação crível quanto a seu futuro.

Assim, o mundo árabe e muçulmano continua estranho aos estudos mais abrangentes sobre democratização em perspectiva comparada e à reflexão acerca da política em países em desenvolvimento. Dessa forma, a maioria dos trabalhos referentes a esses processos foi realizada por especialistas na região, principalmente situados em instituições acadêmicas do mundo anglo-saxão, no interior do que se convencionou chamar de "Area Studies". É possível sistematizar esses trabalhos em quatro grandes conjuntos, como se fará a seguir.

Um primeiro conjunto de trabalhos já foi discutido no capítulo 2 - ao menos, por meio da análise de alguns de seus mais importantes "representantes" atuais. Trata-se da "escola culturalista", aquela que recebeu a maior herança do discurso orientalista clássico. Em geral, esses trabalhos destacam fatores culturais específicos dessas sociedades como a causa da persistência do autoritarismo no mundo árabe. O núcleo dessa perspectiva é a consideração, matizada ou não, de 
alguma forma de incompatibilidade entre o Islã e a democracia - ou, de forma mais ampla, entre o Islã e a modernidade em moldes ocidentais (além dos trabalhos de Lewis, Gellner e Ajami, destacam-se Vatikiotis, 1987; Kedourie, 1992; Pryce-Jones, 1989). No interior desse tipo de explicação, como já vimos, o Islã consistiria não apenas em uma religião, mas também em um sistema prescritivo da organização social e política de um povo, que negaria a idéia de soberania popular (a única soberania possível seria a divina), sendo incompatível, por conseguinte, com a idéia do voto majoritário. Além disso, outros trabalhos apontam como impeditivos à democratização a intolerância e falta de confiança com relação aos que não fazem parte de um círculo próximo (geralmente descrito como a tribo ou o clã), a propensão à aceitação de teorias conspiratórias pelas sociedades muçulmanas (Pipes, 1996; Entelis, 1989; Ajami, 1981) e o patriarcalismo próprio à família árabe (Sharabi, 1988).

Um segundo grande conjunto de trabalhos centra-se em explicações históricas e estruturais para a persistência dos regimes autoritários no mundo árabe. Boa parte desses trabalhos analisa a formação dos estados árabes e as maneiras pelas quais as relações com determinados setores das sociedades e as instituições estabelecidas pelas potências colonizadoras levaram a um determinado padrão de relações entre estado e sociedade que se manteve após as independências desses estados. Muitos desses trabalhos destacam a artificialidade dos estados criados pelos colonizadores, cindidos internamente e desprovidos de experiências e instituições democráticas durante o período de colonização. (AlKhafaji, 2004; Anderson, 1987 e 1995; Owen, 1992; Barakat, 1993; Turner, 1989). Owen (1992: 16-17), exemplarmente, destaca como características fundamentais do estado colonial - imediatamente anterior à independência dos estados do Oriente Médio e determinante para a sua configuração - a aliança entre os colonizadores e lideranças locais conservadoras (em geral grandes proprietários de terra ou lideranças tribais), a instituição de uma política de cisão da sociedade por meio do reavivamento ou da criação de divisão étnica, religiosa ou tribal (como, por exemplo, entre shi'tas e sunitas no Iraque) e a exigência de um determinado "superávit colonial", o qual, quando não atingido, deveria ser coberto por meio de empréstimos da metrópole, o que impossibilitava o desenvolvimento da economia local (análise bastante semelhante é fornecida por Barakat, 1993: 6-7) - uma série 
de políticas acompanhadas por um sistemático processo de alienação cultural do colonizado, como atesta o depoimento de Fanon com que comecei este capítulo.

Seguindo ainda a análise de diversos desses autores, a sociedade civil árabe e muçulmana pós-independência encontrar-se-ia em posição de dependência com relação ao estado: a burguesia teria se desenvolvido em uma estrutura em que seus interesses estariam fortemente ligados (ou mesmo corresponderiam) aos de elementos importantes do estado, dependendo deste para a manutenção desses interesses e para a supressão de grupos com objetivos antagônicos (Bellin, 2000; Niblock, 1998; Ayubi, 2006). Um segundo subconjunto de trabalhos que seguem explicações históricas e estruturais centra-se na idéia de que os estados árabes ou muçulmanos, em sua maioria, seriam rentistas - suas fontes de recursos não passariam pela tributação, mas sim da exploração de recursos naturais, em especial o petróleo (ou o gás natural, no caso Argelino), ou de outras formas de arrecadação independentes do desenvolvimento da economia interna - como auxílio externo, transferências militares e direitos de passagem. Na ausência de taxação, o governo conseguiria se isolar das demandas sociais por representação e, com os recursos disponíveis, seria capaz de distribuir concessões, subsídios e outros tipos de favores em troca de apoio político (Ross, 2001; Luciani, 1988). Em síntese, esse conjunto de trabalhos, bastante distintos entre si, pode ser lido como tentativas de compreensão de processos políticos a partir da consideração da disputa entre grupos internos e de suas relações com grupos e estruturas de poder externos, além das relações entre esses grupos e o estado, sendo esse conjunto de relações situadas historicamente.

Um terceiro conjunto de trabalhos, os quais entendo como sendo bastante complementares ao anterior, destaca os fatores regionais e internacionais como responsáveis pela manutenção dos regimes autoritários. Entre os fatores regionais, aponta-se com freqüência para o conflito árabe-israelense e para as outras disputas como responsáveis pela (ou como justificativa para) manutenção de grandes aparatos de segurança, controlados por um regime centralizador (Gause, 1995; Solingen, 1996). Além disso, diversos trabalhos apontam para o apoio diplomático, financeiro e militar das grandes potências aos regimes autoritários da região, constituindo importantes sustentáculos para sua manutenção (Shlaim, 1995 e 1988; Sayigh e Shlaim, 1997; Gerges, 1999; Khalidi, 2005). 
Por último, um quarto conjunto de trabalhos, sem negar a maneira pela qual construíram-se os atuais aparatos estatais dos estados árabes, coloca no centro da análise as instituições de repressão criadas pelos regimes autoritários e as estratégias por eles utilizadas para sua perpetuação, como manipulações ideológicas, acordos com lideranças regionais e exploração de uma alegada "ameaça islamista" no caso de uma abertura política. Nesse sentido, a persistência do autoritarismo seria explicada fundamentalmente pela existência de um aparato estatal coercitivo capaz de suprimir iniciativas democráticas surgidas no interior da sociedade, e não pela ausência de qualquer pré-requisito social ou cultural à democratização (Bellin, 2004). Tais fatores seriam a causa determinante do fracasso das tentativas de abertura política nesses estados, segundo essa literatura (Deegan, 1993; Al-Khalil, 1989; Baram, 1991). Estes trabalhos, sobretudo quando tentam compreender esses processos de construção e manutenção dos aparatos coercitivos à luz da consideração das dinâmicas sociais internas e das relações internacionais desses estados fornecem, igualmente, alguns importantes pontos de reflexão na análise de casos específicos.

A análise dessa literatura sobre as sociedades árabes e muçulmanas nos permite esclarecer alguns pontos sobre os casos específicos que serão analisados, ao mesmo tempo em que possibilita alguns avanços quanto às considerações teóricas já realizadas. Muitos desses estudos fornecem importantes análises de disputas internas pelo controle do estado, levando em conta o impacto que a colonização apresentou sobre esses processos. Destaco, aqui, os trabalhos de Owen (1992), Ayubi (2006), Barakat (1993), Gran (1996), Turner (1989) e Batatu (1979), sobretudo pela sofisticação em destacar as dinâmicas entre os diversos grupos internos, com uma consideração bastante apurada sobre as formas como solidariedades e práticas "tradicionais" passam a fazer parte do contexto de "modernidade" dessas sociedades, a partir dos processos políticos e sociais fundamentais do século XX - particularmente a colonização européia, os processos de criação de estados nacionais, a ascensão de novos grupos sociais, os processos de independência e, por fim, as disputas em torno do estado no período pósindependência. Esses processos foram fundamentais em praticamente todos os estados árabes e muçulmanos e são as principais balizas históricas para a consideração da modernidade nessas sociedades. 
Essa interpenetração entre traços sociais tradicionais e modernos, entendida como um processo que marca de forma profunda o processo de modernização das sociedades periféricas e pós-coloniais - apesar de não exclusivo a elas, evidentemente - é de grande relevância para uma análise dessas sociedades que se queira "descolonial" - ou, em outros termos, que mostre as múltiplas relações entre modernidade e colonialidade do poder, como já indiquei anteriormente. Ela permite uma consideração crítica de diversos aspectos da modernidade na forma como se realiza nessas sociedades que, em uma estrutura de análise eurocêntrica, seriam descritos com um linguajar dos "resquícios" ou dos "obstáculos". Portanto, irei me concentrar aqui nesta dimensão da "crítica pós-colonial" - na forma como a descrevi no capítulo anterior.

No caso das sociedades árabes e muçulmanas, a compreensão das formas de solidariedade colonial e pós-colonial entre o "arcaico" e o "moderno" parece servir como guia de correção de trabalhos exclusivamente "externalistas", que tendem a identificar todos os aspectos tidos como problemáticos dessas sociedades como conseqüências diretas e exclusivas das diversas formas de imperialismo sob as quais elas estiveram submetidas desde meados do século XIX. Não se trata, contudo, de uma escolha entre extremos: o relevante é demonstrar, como já indicamos no capítulo anterior, que a distinção entre interno e externo, nesse caso, não apresenta qualquer ganho analítico, sendo mais relevante mostrar como há uma articulação incontornável e uma mútua constituição dessas duas dimensões. Nesse sentido, não é apenas o "imperialismo" que forneceu a dimensão externa, mas o capitalismo moderno em expansão e que, a partir do século XVIII, passa a incorporar o Império Otomano como sua "periferia em constituição" - como se, nos termos da análise de Timothy Mitchell (1991) a "colonização", em suas várias dimensões, fosse, no caso das sociedades árabes e muçulmanas, anterior ao imperialismo.

Mais relevante do que apontar um caráter ideal desse tipo de perspectiva crítica, é crucial notar que ela marca a reflexão de diversos desses historiadores e sociólogos anti-eurocêntricos que se debruçam sobre a região. Turner, por exemplo, aponta que

“...los processos internos de cambio dentro de la estrutura otomana están claramente inmersos em la trama de la 
reestruturación masiva del contexto externo de la economia otomana. La comercialización del sistema agrario otomano, ademas, no era un rasgo particular al decadente imperio islâmico, sino um proceso comun a una diversidad de sistemas sociales bajo el impacto del capitalismo decimonónico. La subordinación de la economia islâmica a las relaciones capitalistas de producción y su rechazo a la periferia de la economía mundial no requiere de suposiciones orientalistas acerca de las diferencias esenciales entre la cultura oriental y la occidental para que los sociólogos y los historiadores entiendan estos procesos de acumulación de capital” (Turner, 1989: 108) ${ }^{85}$.

Turner aponta ainda que grande parte dos esforços atuais que se alinham a uma forma de raciocínio sociológico eurocêntrica são tentativas de transposição de "modelos" de análise acerca de geração do capitalismo para casos periféricos como se uma "sociologia da origem do capitalismo" equivalesse a uma "sociologia do desenvolvimento" (Turner, 1989: 104).

Diversos processos sociais de grande relevância são exemplos dessa dimensão da realização da modernidade nessas sociedades. Importantes análises acerca da formação da sociedade iraquiana, por exemplo, (sobretudo Batatu, 1979; Gran, 1996 e Baran, 1997) buscam mostrar que não há um antagonismo entre, de um lado, a participação das tribos nas dinâmicas políticas e sua manutenção como formas de solidariedade social e, de outro, a modernização da sociedade e do estado iraquianos. As tribos, como "forma de solidariedade tradicional", segunda uma visão eurocêntrica da modernidade, não se opõem a uma certa forma específica de realização da modernidade, sobretudo nesse contexto periférico.

O seguinte trecho, de Roger Owen, vai no mesmo sentido da hipótese apresentada:

${ }^{85}$ Evidentemente, esse não é um processo apenas econômico, mas também social e cultural. É, sobretudo, a partir do século XIX que a modernidade ocidental, com seus valores e formas de vida, passa a constituir uma referência fundamental para a cultura no mundo árabe e muçulmano, seja como referência a ser seguida ou como o símbolo máximo do que deveria ser rejeitado (ver Hourani, 2005). 
"In many analysis of Middle East politics, the so-called traditional categories of tribe, sect or clan remain fixed and unchanging, giving them a timeless quality in which the same struggles over differences of community or religion are endlessly repeated in patterns that have little to do with national boundaries or national politics. Or, if the creation of new and larger loyalties is allowed, these are supposed to transcend the new boundaries so as to create pan-Islamic or Pan-Arab aims and forms of organization. From this follow the still influential observation that politics in the Arab world continue to be a struggle between groups that are concerned with issues that are either smaller than those to be found at the state level or larger... Against this, I would like to argue the counter proposition, that methods of political organization and styles of political rhetoric are largely defined by the context and that, from the colonial period on, this context was created by the territorial state" (Owen, 1992: 20; destaque meu).

A idéia de "contexto", apresentada por Owen, serve precisamente para a continuidade de nosso argumento. Expandindo a definição de Owen de acordo com o que já foi apresentado aqui, diríamos que, mesmo no período imediatamente anterior ao colonialismo direto, o contexto das disputas políticas no mundo árabe e muçulmano era o contexto da modernidade capitalista: uma modernidade aberta à contingência e em constante mutação, a partir das disputas específicas entre atores sociais, nas diversas sociedades em que esse processo se instalava. Apenas tendo isto em conta é que se pode compreender a observação de do historiador Peter Gran de que só faz sentido se falar em "modernidade" - para o caso específico das sociedades árabes e muçulmanas - a partir dos séculos XIX e XX, com a expansão do capitalismo em níveis globais. Apenas então, em nível mundial e de forma interrelacionada, "...political elites had to devise comprehensive strategies to diffuse class conflict, the mass struggle typifying modern history having begun" (Gran, 1996: $337)^{86}$.

${ }^{86}$ Cito, correndo o risco de soar repetitivo, um outro trecho de Gran, no qual igualmente apóia-se a hipótese da integração das tribos a uma história/sociologia da modernidade: "Social history permits the scholar to integrate the history of tribal-ethnic states into modern history or, more broadly, into the idea of modernity in a less reserved and judgmental fashion. In tribal-ethnic states, social historians have shown, dominant elements on the scene - alone or in collusion with foreigners - set up a strategy of rule in which class conflict 
Debrucemo-nos um pouco mais sobre este caso, pelo momento. O Iraque sob o mandato britânico (1920 a 1932) e no período da monarquia (1932 a 1958) foi tema de algumas importantes e influentes análises históricas, a mais importante sendo o estudo de Batatu sobre a estrutura de classes da sociedade iraquiana e as relações que se estabeleceram entre as antigas classes sociais dominantes e as novas classes urbanas, no período de formação do Estado iraquiano (Batatu, 1979). Um importante debate sobre o período de formação do Estado iraquiano refere-se à maneira pela qual as transformações econômicas por que passava e as decisões políticas tomadas durante o mandato e a monarquia do país impactaram nas formas como se organizava a sociedade e como serviram para o fortalecimento ou a dissolução de antigos traços sociais pré-capitalistas, e para o estabelecimento de uma dependência da sociedade perante o Estado (além do livro fundamental de Batatu, destacamos também Al-Khafaji, 1986 e Farouk-Sluglett e Sluglett, 1983 e 2001). Para o período Ba'thista (1968-2003), a literatura é menos rica, apesar de crescente, uma vez que 0 acesso às fontes iraquianas era praticamente impossibilitado pelo regime ${ }^{87}$. Mesmo assim, é possível perceber na literatura uma preocupação central sobre as causas da manutenção do regime, em especial devido à ausência, observada por alguns estudiosos, de bases sociais de sustentação da liderança política ${ }^{88}$. Alguns desses estudos destacam as maneiras pelas quais o Ba'th (e, sobretudo, Saddam Hussein) utilizou-se de manipulação ideológica e do reavivamento de antigas cisões sociais (sobretudo tribais) para seu próprio fortalecimento (Baram, 1991 e 1997; Karsh, 1991).

As considerações iniciais sobre a organização tribal e a modernidade, assim como essa breve revisão bibliográfica, abrem caminho para uma observação específica acerca do papel das tribos na constituição da modernidade iraquiana. Como aponta Batatu, a propriedade da terra e a divisão social em classes só se tornam importantes no século XIX, com o início da ligação do país a um mercado imperial britânico, sedimentado na indústria de larga escala. Antes disso, era possível perceber uma grande variedade de fatores de hierarquia, variando

is disguised by tribal-ethnic conflict, tribal-ethnic conflict in turn disguising the primary contradiction, gender contradiction" (Gran,1996: 11).

${ }^{87}$ Uma influente revisão da historiografia sobre o Iraque moderno pode ser encontrada em Farouk-Sluglett e Sluglett (1991).

${ }^{88}$ Esse tema já é trabalhado por Batatu (1979). Outros autores, principalmente Baram (1989 e 1997), destacam como o regime de Saddam precisou absorver lideranças com origens sociais e antecedentes políticos diversos para que pudesse garantir sua sustentação. 
amplamente de cidade para cidade. Só então, com a estabilização, expansão e concentração da propriedade privada, o aumento no papel do dinheiro e a consolidação do papel do estado é que a propriedade torna-se o fator de diferenciação mais relevante (Batatu, 1979: 8 e 11). Dado esse fato, a análise da modernidade iraquiana, com seus múltiplos aspectos, dimensões e tensões internas, deve passar por um momento central de consideração da inserção do Iraque nos processos globais de expansão dos padrões do capitalismo (e, de maneira mais ampla, da modernidade) e das maneiras como os atores internos, inseridos nesse panorama mundial, tensionam em direção a formas específicas da modernidade, a partir dos elementos culturais e sociais já presentes nessa sociedade. Esse problema é equivalente àquele destacado por Batatu: "the long range effects upon pre-existing norms and structures of the gradual transformation of Iraq into an adjunct of the industrial capitalist system... and of the attendant or related facts and processes" (Batatu, 1979: 11).

A relação entre as tribos (e as lideranças tribais, sobretudo) e a política iraquiana parece constituir um importante veio de análise da constituição do estado iraquiano, da identidade nacional do país e das principais disputas sociais em cada um desses momentos. A análise dessa relação passa por considerações de tipos diversos: as variações nas formas de propriedade da terra, as relações entre lideranças tribais e as elites dirigentes nos diferentes períodos em consideração e a participação do tribalismo na identidade nacional iraquiana.

Como mostram Farouk-Sluglett e Sluglett (1983), antes de 1820, com a penetração colonial britânica, a cada uma das tribos iraquianas equivalia a sua dīra, uma porção de terra que a tribo ocupava enquanto pudesse protegê-la, sem se constituírem em proprietários. A capacidade de intervenção otomana era limitada e as tribos resistiam à maior parte das investidas de controle. Contudo, por volta de 1870, com as Reformas do Tanzimat, os avanços técnicos e administrativos do Império Otomano e a abertura do Canal de Suez (1869), o Império consegue ampliar seu controle sobre as províncias que hoje constituem o Iraque. O interesse otomano em estabelecer maiores controles sobre o uso da terra pode ser visto sob o pano de fundo do maior interesse europeu na região, aliado à transição de uma economia de subsistência para a agricultura comercial, sobretudo para a exportação de grãos (Farouk-Sluglett e Sluglett, 1983: 492; Tripp, 2005: capítulo 1). Antes disso, Midhat Pasha, governador otomano para as províncias da região entre 1869 e 1872 , 
havia tentado, sem sucesso, a introdução de um Código de Terras Otomano (já formulado em 1858), que previa a concessão de terras estatais para a exploração da agricultura mediante impostos. Nos anos seguintes, seguiram-se disputas pela posse de terras entre líderes tribais que levou à quase desintegração das confederações tribais (Farouk-Sluglett e Sluglett, 1983: 495; Batatu, 1979: capítulo $6)$.

Como aponta Batatu, essa decadência da estrutura tribal, no período prémandato, se devia a uma série de fatores em operação desde o século XIX, sobretudo a inserção do Império Otomano no capitalismo mundial, as reformas administrativas otomanas, o fim da dinastia Mamluk - que governava de forma quase independente as províncias "iraquianas", o que levou à sua re-incorporação ao Império -, a ampliação da navegação e da comunicação, o governo reformista de Midhat Pasha, os impactos da revolução turca de 1908 e os impactos decorrentes das leis de terras (Batatu, 1979: 73). Com essas mudanças, os shaikhs passaram a dispor da possibilidade de ganhos da exploração comercial de suas terras - 0 "camponês tribal" vai se tornando mais valioso que o "guerreiro tribal" (Batatu, 1979: 77).

Isso se altera com o mandato britânico. Em síntese, durante esse período, há uma aliança entre os grandes shaikhs e os britânicos. Estes precisam dispor das forças locais para manter o controle sobre o país. Além disso, o fortalecimento das tribos servia a uma política de oposição às cidades, de onde surgia a maior oposição ao mandato. Os líderes tribais, por sua vez, recebem imensos benefícios em termos políticos, fiscais e de concessão de terras (Marr, 2004: 23; Batatu, 1979: 91). Isso leva a um processo social, cuja importância e impacto são indisfarçáveis, de reversão no processo de desintegração tribal. Como apontam Farouk-Sluglett e Sluglett (1983: 52), esse processo é vital à penetração desigual do capitalismo no Iraque, com a criação e perpetuação daquilo que, normalmente, seria entendido como relações pré-capitalistas de produção no campo.

Nos termos utilizados neste trabalho, o mandato serve à inserção do tribalismo na modernidade iraquiana. Tribalismo e modernidade, nesse sentido, não se anulam - sobretudo se considerarmos que esse tribalismo não é parte apenas da história iraquiana, mas também britânica ou, enfim, ocidental. Batatu sintetiza adequadamente esse processo: 
“... it should be clear that the semifeudal shaikhly structure of the 'mandatory' period did not derive its strength from any inner vitality. Life was pumped into it artificially by an outside force that had an interest in its perpetuation. In other words, the sheikhs and aghast, at least for the most part, ruled not by virtue of their own power or the willingness and loyalties of their peasants, but by the desire and sufferance of the English" (Batatu, 1979: 99).

O caso do Egito também é particularmente interessante para observarmos este entrelaçamento entre a modernidade capitalista global e forma como esta se realiza em uma sociedade de capitalismo periférico e pós-colonial - no sentido temporal deste termo ${ }^{89}$. É fundamental perceber que a inserção da economia egípcia na moderna estrutura internacional capitalista se dá anteriormente à penetração colonial britânica e à conversão do Egito em uma de suas maiores colônias, na segunda metade do século XIX. Como expressa Albert Hourani (2006: 372), o Egito se torna um satélite para apenas posteriormente tornar-se uma colônia.

O Egito (ainda como uma província otomana) passa por sua primeira grande transformação sócio-econômica no início do século XIX, sob o governo de Muhammad Ali (1805-1848). Este período é fundamental para a inserção do Egito no capitalismo mundial e para o aumento de sua independência com relação ao Império Otomano, processo que dependeu de uma série de reformas internas conduzidas por esse eminente político. Ali realizou uma sistemática reforma do sistema de terras egípcio e de sua estrutura burocrática, tendo paulatinamente conquistado liberdade de ação frente à burocracia estatal otomana. Entre as mais importantes mudanças está a centralização das terras pelo estado - com a abolição do cultivo tributário, tradicional na região, e com a instituição de um imposto pago pelos camponeses diretamente ao estado - e o fomento de seu uso para o plantio de algodão. Ao longo desse período, foi-se instituindo um sistema de monopólio por meio do qual o estado comprava a colheita dos camponeses a preço fixo e revendia

${ }^{89}$ Além de ser um caso bastante promissor para uma comparação com a formação das sociedades latino-americanas. Não é por outro motivo que estudiosos da sociedade e da economia egípcia estiveram em diálogo teórico pesquisadores latino-americanos durante a fase mais produtiva da "sociologia da dependência" (ver, por exemplo, Amin, 1976; para um estudo mais recente que busca atualizar essas perspectivas, ver Vitalis, 1995). 
aos exportadores estrangeiros em Alexandria; ao mesmo tempo, a administração da província passou a permitir a compra de terras egípcias por estrangeiros.

Esse sistema bastante centralizado durou até os últimos anos do reinado de Muhammad Ali, quando pressões européias obrigaram-no a abrir mão do monopólio sobre o algodão e outros produtos. Nesse processo, o Egito assumiu uma típica posição de economia de plantação, passando a exportar matérias primas e a importar produtos industrializados determinados pelo mercado mundial, apesar de uma série de esforços de Muhammad Ali para que ali se avançasse um processo de industrialização - algo que irá diminuir gradativamente nas administrações seguintes (Turner, 1984: 242; Hourani, 2006: 361).

Essa reforma do sistema de terras e de produção no Egito deve ser visto em uma perspectiva maior, que leva em conta tanto o choque das diversas regiões otomanas com o capitalismo industrial em constituição e expansão, quanto a tentativa de gerar respostas a ele $^{90}$. Essa foi a era de reformas conhecidas como Tanzimat, a que já me referi acima. Como bem expressa Ayubi:

\begin{abstract}
"The reforms, initiated by the Turks, the Egyptians, the Tunisians and others in the period from 1800 to 1850 (often known as tanzimat), were in large measure an attempt at 'defensive modernization' as a way of keeping the European encroachment at bay. Bureaucratic centralization, registration of land ownership, the building of new armies and modern educational systems, and the attempt to reassert the control of government over the economy and to maximize tax revenues, were the main aspects of such reforms" (Ayubi, 2006: 87).
\end{abstract}

Porém, ironicamente, essas reformas, em vez de tornarem esses estados mais independentes das potências européias, os tornaram mais dependentes, facilitando o processo de penetração econômica capitalista - e, logo à frente, colonial. No caso egípcio, isso não se esgotou no governo de Muhammad Ali, mas estendeu-se pelas três décadas seguintes, quando seus sucessores estreitaram a dependência financeira com investidores europeus. A ocupação britânica em 1882 -

${ }_{90}$ A importância do mercado internacional de algodão centralizado na Inglaterra para o avanço da revolução inicial - um mercado no qual o Egito passa a se inserir décadas antes de converter-se em colônia - é destacado por Eric Hobsbawm (1977: capítulo 2). 
justificada em termos de uma pretensa perturbação da ordem por movimentos populares - completou o processo mediante o qual a terra egípcia passou ao controle de uma classe capitalista agrária, que produzia praticamente um único produto para o mercado mundial, aliada aos interesses do colonialismo britânico (ver Marsot, 1985: 86-87). O Parlamento egípcio, em funcionamento durante o período colonial sob a tutela de representantes britânicos, era dominado por proprietários de terras com interesses bastante distantes dos pequenos produtores ou de qualquer objetivo determinado de industrialização que contrariasse suas posições. Como aponta Marsot (1985: 87), "that economic link with Britain was naturally reflected in the political relationship between the two countries and explained the reluctance of Egyptian politicians to push the British government too hard".

Sob o colonialismo, o processo de incorporação do mundo árabe e muçulmano ao sistema mundo capitalista obedeceu a uma série de processos que podem ser melhor entendidos tendo em vista as reflexões de Gramsci e Trotsky, apresentadas no capítulo anterior. Dessa maneira - usando ainda um linguajar dualista ara enfrentar a sua própria lógica - podemos observar como a formação desse capitalismo periférico só pode ser entendida pela amálgama de antigas práticas e estruturas tipicamente pré-capitalistas com as novas estruturas necessárias à acumulação capitalista, esta realizada no centro do sistema e pelas elites locais integradas a ele. Ayubi indica que traços daqueles modos anteriores eram preservados ao máximo, sobretudo na agricultura, como forma de garantir a reprodução barata da força de trabalho (Ayubi, 2006: 97; para uma análise semelhante quanto ao caso brasileiro, ver Martins, 2004).

Como afirma Samir Amin, esse capitalismo periférico é ao mesmo tempo engendrado pelo imperialismo e por ele limitado. Amin faz uma interessante crítica às "limitações" impostas ao desenvolvimento de uma burguesia nesses estados periféricos, e particularmente no Egito - bastante próxima, como veremos à frente, a algumas análises desenvolvidas para a compreensão da sociedade brasileira. Com a colonização, as classes proprietárias locais submetem-se de forma mais decisiva à divisão internacional do trabalho, ao mesmo tempo em que alcançam maiores lucros ao manterem instituições que, na "modernidade-capitalista original", seriam consideradas pré-modernas - como formas de exploração do trabalho nãoassalariadas e a funcionalização de relações de dependência pessoal. Como 
aponta sinteticamente Samir Amin, essa "burguesia" em gestação nas regiões periféricas do sistema mundo - não menos modernas do que as localizadas no centro, diríamos aqui, mas sobretudo visíveis a partir das margens desse sistema têm uma peculiaridade só compreensível se levado em conta o caráter assimétrico e global desse capitalismo:

\begin{abstract}
"Du fait de l'existence antérieure de relations de production non capitalistes dans l'agriculture, la nouvelle bourgeoisie agraire - de latifundiaires ou de koulaks - se présente d'une manière complexe, mi-capitaliste, mi-précapitaliste... Elle est capitaliste, non pas parce qu'elle produit pour le marché capitaliste, mais parce que cela lui impose d'adopter des comportements qu'exige la compétition capitaliste : investir, emprunter, calculer, recourir au moins partiellement au travail salarié, etc. En même temps, elle utilise, et parfois renforce, des méthodes d'exploitation précapitalistes provenant des relations antérieure" (Amin, $1976: 37)$.
\end{abstract}

A análise da formação do capitalismo periférico fornece uma série de problemas que não podem ser resolvidos, como se vê no caso egípcio, quando se recorre a idéias como a de uma burguesia progressista e industrializante, tida como modelo exportável para qualquer situação de desenvolvimento. Nesse caso - assim como em grande parte das modernas sociedades periféricas -, a incorporação ao mercado internacional criou uma classe capitalista agrária que esteve recompensada pela exploração de matérias primas (ou pela industrialização em aliança com o capital internacional, como no caso brasileiro a partir da metade do século $X X)$, mas que não desempenhou um papel social progressista de qualquer tipo. Uma burguesia moderna, sim, mas de outro tipo, apenas reconhecível a partir de um olhar crítico lançado da periferia desse sistema mundo moderno; uma burguesia típica de uma estrutura social periférica que não irá se desintegrar de imediato com o fim do período colonial ${ }^{91}$.

Os dois casos acima são exemplares daquilo que uma série de análises das últimas décadas vêm apontando sobre as sociedades pós-coloniais da região, não

91 Para uma análise das incontáveis dificuldades que os regimes pós-independência encontraram para reformar suas estruturas sociais, ver sobretudo Ayubi (2006), Nasr (1999) e Turner (1984). 
apenas no que se refere à sua formação social, mas também no que se refere às relações entre estado e sociedade e aos incentivos para a mobilização política. Como aponta Nasr (1999), os estados muçulmanos posteriores às suas independências tiveram de lidar com as heranças institucionais do período colonial. Contudo, as lideranças políticas envolvidas mais diretamente nessas tarefas, na maioria dos casos, foram formadas no interior daquelas mesmas instituições, o que acabou por levar a uma quase sistemática "indigenização do estado colonial", mesmo sem a presença do colonizador - algo para o qual Fanon já alertava, em meio aos conflitos de libertação nacional (ver Fanon, 2005 [1961]: capítulo 3). A tarefa de criar uma aliança entre a população para apoio aos novos regimes era bastante diferente da tarefa anterior de criar uma aliança nacional de libertação. Como aponta Owen, os programas econômicos levados a cabo pela metrópole, em geral criticados pelas lideranças nacionalistas anti-coloniais, foram reciclados por estas como planos de ação imediata. Essas elites, em geral ocidentalizadas, encontravam-se na maioria das vezes distantes dos setores majoritários de suas sociedades e repousavam sobre aparatos militares descomunais, herdados do período colonial. Essas gigantescas máquinas militares serviram como sustentáculos de uma série de regimes que se originaram nesse período póscolonial, derivados dos costumeiros golpes de estado que assolaram a região como no Iraque em 1936 e 1958, na Síria em 1949 e no Egito em 1952 (Owen, 1992: 24-25; ver também Ayubi, 2006).

Tendo em vista essa frágil estrutura de relações de equilíbrio entre estado e sociedade, uma série de estudos contemporâneos vem apontando a peculiaridade dos padrões de mobilização política de oposição aos seus regimes, no período póscolonial - uma oposição que, ao menos desde a década de 1970, vem se articulando cada vez mais na linguagem do Islã político ${ }^{92}$, este mesmo um fenômeno de massa fortemente marcado pelas características estruturais de suas sociedades, em período posterior às independências.

\footnotetext{
${ }^{92}$ As referências contemporâneas para esta questão - que infelizmente não poderá ser aprofundada neste trabalho, - são numerosas e crescentes, inclusive devido à repercussão que o islamismo vem tendo em toda a mídia ocidental. Ver, por exemplo, Halliday (1995), Esposito (1995), Esposito e Voll (1996), Mahmood (2005), Demant (2004), Eickelman e Piscatori (2004). Quanto ao caso egípcio, que vem recebendo grande atenção na academia devido à importância da Irmandade Muçulmana e suas disputas com o regime atual, ver Adeb-Kotob, (1995) Esposito e Voll (1996); Kombargi, (1998); Kepel (1993); Roy (1992); ElGhobashy (2005) e Wickham (2002).
} 
Os casos iraquiano e egípcio são importantes para percebermos como a modernidade capitalista, em sua expansão mundial, engendra formas sociais que não correspondem à auto-identificação européia do moderno, mas que se encontram ligadas a ela de forma inextricável. A política tribal e os elementos sociais e econômicos do capitalismo agrário, dessa maneira, podem ser entendidos como componentes do quadro da modernidade "também" européia - da mesma forma que, como veremos logo à frente, a escravidão é parte da história da constituição da modernidade, vista a partir de suas margens ${ }^{93}$.

Em todos esses casos, refletir a partir de uma agenda "pós-colonial" não significa apenas "culpar" a escravidão ou a ação imperial pelas mazelas sociais contemporâneas dessas sociedades, em uma espécie de exercício pretensamente científico que já carrega as respostas junto dos questionamentos. Trata-se, na verdade, de buscar compreender como essas formas tidas como "arcaicas" interpenetraram as estruturas ditas "modernas" desses países, constituindo modernidades periféricas fundadas nessas desigualdades materiais e simbólicas desigualdades que o imperialismo elevou a níveis dramáticos.

${ }^{93}$ Uma série de estudos contemporâneos sobre sociedades pós-coloniais vem tentando resolver questões semelhantes a estas. No caso da Índia, por exemplo, grande parte da discussão nas últimas décadas centra-se no estudo das relações entre a estrutura política e social engendrada no período colonial (de 1757 a 1947) e a construção da nação a partir da independência (Chatterjee, 1993; Chakrabaty, 2002; Pathak, 2004; Sen, 2005). Diversos estudos apontam, por exemplo, para o papel de reforço da estrutura de castas desempenhado pelo governo imperial britânico, sobretudo como forma de controle administrativo (Dirks, 1992; Andaya, 1997; Chakrabarty, 2002). 


\title{
5. Marxismo dialético brasileiro e a busca da especificidade da modernidade periférica
}

\author{
“...nos países saídos da colonização, o conjunto de \\ categorias históricas plasmadas pela experiência intra- \\ européia passa a funcionar num espaço com \\ travejamento sociológico diferente, diverso mas não \\ alheio, em que aquelas categorias nem se aplicam com \\ propriedade, nem podem deixar de se aplicar, ou melhor, \\ giram em falso mas são a referência obrigatória, ou, \\ ainda, tendem a um certo formalismo. Um espaço \\ diverso, porque a colonização não criava sociedades \\ semelhantes à metrópole, nem a ulterior divisão \\ internacional do trabalho igualava as nações. Mas um \\ espaço de mesma ordem, porque também ele é \\ comandado pela dinâmica abrangente do capital, cujos \\ desdobramentos the dão a regra e definem a pauta"
}

Roberto Schwarz (1998: 106)

A constituição da modernidade no Brasil é um capítulo dos mais relevantes para uma discussão sobre o uso de raciocínios e categorias eurocêntricas, quando o que se tem em tela é uma sociedade "não tipicamente" ocidental ou central. Já apontei no final do capítulo 2, por meio da citação de Paulo Emílio Salles Gomes extraída da análise de Paulo Arantes acerca do sentimento de dualidade da experiência cultural brasileira, como esse drama da auto-identidade aponta uma contradição plena de conseqüências no seio da experiência cultural e social brasileira. Repito a citação (pela sua pertinência e por não poder expressar o tema de forma mais acabada ou elegante): "não somos europeus nem americanos do norte, mas destituídos de cultura original, nada nos é estrangeiro, pois tudo o é. A penosa construção de nós mesmos se desenvolve na dialética rarefeita entre o não ser e o ser outro" (citado em Arantes, 1992: 15).

Esse "entrelaçamento dual entre o mesmo e o outro" (Arantes, 1992: 16) é captado ainda pelo crítico literário Antonio Cândido: “...o brasileiro não pode deixar de viver pendurado no Ocidente e ele deve tentar não viver pendurado no Ocidente. Ele deve tentar fazer uma cultura dele, mas a cultura que ele pode fazer é uma cultura pendurada no Ocidente (...) Nós somos o outro e o outro é necessário para a identidade do mesmo" (citado em Arantes, 1992: 16). Esse dilema difícil de equacionar marca a experiência intelectual brasileira desde seu início, em suas 
manifestações artísticas ${ }^{94}$, sociais e econômicas. Não é por outro motivo que, sem maiores problemas ou constrangimentos, a grande maioria dos brasileiros seria capaz de tecer comentários sobre como os povos orientais são "diferentes de nós, ocidentais" e que "o Brasil tem um povo diferente do europeu, mais humano, mais quente", e daí por diante ${ }^{95}$.

Esse dilema fundamental fornece a problemática que grande parte do pensamento social brasileiro tentou resolver a partir do uso diverso, como se tentou demonstrar anteriormente, de modos de pensar eurocêntricos. Espero que esteja claro por ora que, da forma como apresentamos a apropriação brasileira dessas categorias, esse processo de nutrição teórica não é um "erro" ou uma "falsidade teórica" que deve ser acusada, ao menos da forma como foi proposta por alguns dos maiores pensadores da sociedade brasileira, como Sérgio Buarque e Raymundo Faoro - e, como já foi apontado, ter ajudado a configurar uma "ideologia" conservadora que persiste até hoje, que tende a desvincular nosso "atraso" ou nossas mazelas da estratificação social brasileira, típica de uma sociedade periférica; em outros termos, essa apropriação esconde, ao mesmo tempo, os elementos de dominação de classe e o caráter periférico de nossa formação social.

Contudo, o próprio caráter contraditório da experiência social brasileira faz com que o uso dessas categorias seja, ao mesmo tempo, indispensável e, no mais

94 O próprio Antonio Cândido tratou desse tema de forma clássica em seu Formação da Literatura Brasileira, cuja introdução já aponta uma certa "precariedade" de nossa literatura (ou, dito melhor, uma dependência de outras literaturas que marca sua formação), um "...galho secundário da portuguesa, por sua vez arbusto de segunda ordem do jardim das Musas..." e, ao mesmo tempo, o seu caráter essencial e verdadeiro, uma vez que "Comparada às grandes, nossa literatura é pobre e fraca. Mas é ela, não outra, que nos exprime... Ninguém, além de nós, poderá dar vida a essas tentativas muitas vezes débeis, outras vezes fortes, sempre tocantes, em que os homens do passado, no fundo de uma terra inculta, em meio a uma aclimação penosa da cultura européia, procuravam estilizar para nós, seus descendentes, os sentimentos que experimentavam, as observações que faziam, - dos quais se formaram os nossos" (Cândido, 2007: 11-12). Uma "aclimatação da cultura européia" em uma terra distante que gera resultados culturais, sociais e estéticos ao mesmo tempo ocidentais e não ocidentais - uma marca de nascença da qual não se pode se livrar.

${ }_{95}$ Apesar de não ser capaz de desenvolver este tema aqui, creio que este é um dilema que, com algumas variações, marca a experiência moderna de todos os países latinoamericanos - não é por menos que as figuras shakespearianas de Próspero, Calibã e Ariel foram utilizadas de modos tão diversos para tentar distinguir a identidade do continente, ou que se forjaram expressões como "Extremo Ocidente" para defini-lo. Em tempos mais recentes, Samuel Huntington tentou definir essa região como perfazendo uma "civilização latino-americana" (ver Huntington, 1993) - algo, no mínimo, impreciso e insuficiente. 
das vezes, insuficiente. Tal insuficiência revela-se de maneira mais grave quando o uso dessas estruturas de referências obscurece um dado fundamental da formação social brasileira, que é o fato de esta ter sido formada como "sociedade periférica", sendo essa a forma original e constantemente recolocada de articulação entre o "ser Mesmo" e o "ser Outro".

Os termos problemáticos para a apropriação dessas categorias e formas de pensar foram muito bem formulados por Roberto Schwarz, no trecho que serve como epígrafe a este capítulo. A estrutura de atitudes e referências eurocêntricas, nas sociedades periféricas, apresenta, dessa forma, um estatuto problemático, uma vez que, para revelarem dados fundamentais dessas sociedades, devem passar por uma espécie de "rotação de perspectiva" - algo para além de uma primeira "adaptação" - que desvele as formas como a modernidade, desde a sua formação primeira, articula-se à colonialidade. Como apontamos no capítulo anterior, essa rotação de perspectiva é um processo adiante de uma "adaptação de categorias": esta "rotação", realizada por uma série de autores críticos como aqueles que analisamos neste capítulo, é o processo pelo qual aquelas categorias passam a dizer respeito a realidades sociais compreendidas a partir de uma idéia de modernidade que incorpora o aspecto da colonialidade como seu dado fundamental.

No pensamento social brasileiro, poucos autores concentraram-se tão intensamente nesse exercício de reinvenção teórica a partir de uma consideração do caráter periférico da formação social brasileira como aqueles que, de formas diversas, ligaram-se ao chamado "Seminário d'O Capital" ou estiveram próximos ao que se costuma chamar de "Escola Paulista de Sociologia". Refiro-me, sobretudo, às obras de Fernando Henrique Cardoso, Octavio lanni, Roberto Schwarz, Fernando Novais e Florestan Fernandes ${ }^{96}$.

Não creio que exista uma denominação precisa que abarque a obra de todos esses autores, nem creio que seja o caso de forjá-la. Esses autores possuem

96 A escolha desses teóricos, evidentemente, não exaure o elenco das contribuições brasileiras a esse exercício de reflexão teórica - uma vez que não nos centramos em teóricos fundamentais como Celso Furtado ou em importantes contribuições das últimas décadas, como as de José de Souza Martins, Luiz Werneck Vianna, Francisco de Oliveira e, mais recentemente, Jessé Souza. Contudo, esse recorte é consciente e visa, sobretudo, recuperar uma série de reflexões que se desenvolveram em um momento de intensa criatividade coletiva interdisciplinar (tanto local quanto mundial) e vigor crítico, bastante incomum em nossa academia atual. 
contribuições mais estreitamente ligadas a disciplinas específicas (sobretudo a História, a Sociologia e a Crítica Literária), mas que se comunicam e se complementam a partir de algumas "formas de ver" o desenvolvimento da sociedade brasileira. O que é relevante, aqui, é apontar os terrenos teóricos explorados pelas principais obras desses autores e a forma como tentaram equacionar o dilema já apontado.

Contudo, é relevante apontar que esses autores não foram elencados a esmo (apesar de não serem os únicos cujas obras poderiam ser abordadas aqui). Creio que eles estão entre os nomes maiores que compartilharam uma "ambiência criativa" (Bastos, 1999: 219) em torno da Faculdade de Filosofia, Ciências e Letras da Universidade de São Paulo (a "Maria Antonia", como até hoje é conhecida), desde o final da década de 50 até meados da década de 60. Essa ambiência criativa, de um potencial acadêmico-científico bastante original para o panorama intelectual brasileiro até então, parece ter dois vetores de origem cruciais. primeiro é aquilo que se convencionou chamar de "Escola Paulista de Sociologia", encabeçada pelo sociólogo Florestan Fernandes (ver Bastos, 1999; Arruda, 2001); o segundo é o "Seminário d'O Capital" - um seminário interdisciplinar de que fizeram parte jovens acadêmicos como José Arthur Giannotti, Fernando Henrique Cardoso, Ruth Cardoso, Octavio Ianni, Fernando Novais e Paul Singer e, de forma mais esporádica, Roberto Schwarz, Bento Prado Júnior, Francisco Weffort, Michael Löwy e Gabriel Bollafi (ver Schwarz, 1998; Arantes, 1992; Lahuerta, 2005). Esses dois "ambientes intelectuais" não caminharam juntos o tempo todo: pelo contrário, em seu início, havia uma forte tensão entre a agenda metodológica explorada pelos jovens orientandos de Florestan Fernandes (sobretudo Cardoso e lanni) e a concepção eclética de sociologia deste mestre (ver Lahuerta, 2005). Mas essa tensão acabou por se mostrar produtiva tanto nas obras do professor Florestan ${ }^{97}$ quanto de seus orientandos.

${ }^{97}$ Apesar de se tratar de uma obra fundamental de interpretação do país e ter servido para
uma série de reflexões ao longo da elaboração deste trabalho, não explorarei com maior
atenção a vasta obra de Florestan Fernandes à luz dos problemas aqui colocados, como
buscarei fazer com os outros autores. Entretanto, a título de nota, gostaria de apontar que
diferentes momentos da obra de Florestan resolvem de maneiras diversas os problemas
advindos da condição periférica do Brasil, um fator fundamental para a reorientação dos
aparatos teóricos com que o autor trabalha ao longo de sua carreira. Tomando apenas dois
de seus livros fundamentais, $A$ Integração do Negro na sociedade de classes (1964) e $A$
Revolução Burguesa no Brasil (1975), é possível perceber que há uma espécie de "rotação
de perspectiva" quanto a este problema (ver Brasil Jr., 2008; Coutinho, 2000), o que o faz 
Não me proponho, aqui, a tratar especificamente de nenhum desses autores ou "vetores", algo que já tem tratamento detalhado na ampla literatura que se vem somando acerca desse momento privilegiado da reflexão social brasileira. Centrome em discorrer acerca das formas como algumas das intuições e abordagens desses autores, sobretudo derivados de um uso crítico e pouco ortodoxo do marxismo, forneceram parâmetros para uma descolonização epistêmica da reflexão sobre a modernidade e o capitalismo brasileiros. Dito de outro modo, creio que esses autores forneceram importantes contribuições para uma reflexão crítica sobre a modernidade a partir de sua periferia, desvelando a colonialidade do poder que Ihe é constitutiva - nos termos como o tema vem sendo desenvolvido atualmente.

Começo por citar o depoimento posterior de um dos membros do chamado Grupo d'O Capital, fundamental para meu argumento:

\begin{abstract}
"O fato é que a certa altura despontou no seminário uma idéia que não é exagero chamar uma intuição nova do Brasil, a qual organizou os principais trabalhos do grupo e teve repercussão considerável. Sumariamente, a novidade consistiu em juntar o que andava separado, ou melhor, em articular a peculiaridade sociológica e política do país à história contemporânea do capital, cuja órbita era de outra ordem" (Schwarz, 1998: 105; destaque meu).
\end{abstract}

A expressão chave dessa síntese é "intuição nova do Brasil" - expressão que, concordando com Roberto Schwarz, não creio ser exagerada. O surgimento de uma

rever o uso de diversas categorias sociológicas, aproximando-se cada vez mais de um aparato teórico marxista e, de alguma forma, daquela "intuição" a partir da qual estavam trabalhando alguns de seus discípulos. Apesar do imenso potencial crítico de $A$ Integração... - um potencial que até hoje vem sendo usado de forma criativa nas melhores tentativas de formular teorias críticas da modernidade periférica, como em Souza (2003) e Coutinho (2000) -, Florestan lançaria mão de forma crucial de uma narrativa da transição e dos obstáculos e de uma versão própria do dualismo, para os quais a categoria de "ordem social competitiva" desempenhava um papel central. Nessa narrativa elaborada por Florestan, a "revolução em São Paulo" teria conservado em seu bojo "reminiscências vivas do passado e estruturas arcaicas que reconstruíam o antigo regime em vários níveis da consciência humana" (Fernandes, 2008 [1964]: 299), uma situação em que se observariam dados "aberrantes" ou "esdrúxulos", uma vez que as relações sociais que depreciavam a população negra seriam uma forma de preservar estruturas sociais arcaicas. Em $A$ Revolução Burguesa..., Florestan reinventaria boa parte de seu aparato teórico e crítico, voltando-se às especificidades da revolução burguesa em uma condição de capitalismo periférico e dependente, em um tipo de revolução em que características estamentais são incorporadas (ou seja, não haveria resquícios ou sobrevivências) como traço estrutural do moderno (para uma análise mais detalhada deste aspecto, ver Cohn, 1999). 
intuição de país em um grupo de estudos que se debruçava sobre O Capital, com objetivos de desenvolver uma "leitura cerrada" da obra - orquestrada, segundo seus membros, pela rigidez do intelecto filosófico de Giannotti e ladeada pelas contribuições do Lukács de História e Consciência de Classe e do Sartre de Questão de Método - não é uma conseqüência necessária ou trivial.

O fundamental é perceber que a escolha pela leitura de Marx, longe de despropositada, foi marcada, ainda segundo Schwarz, por uma série de disputas a que se aferravam os seus jovens membros. Evidentemente, aqueles eram anos de questionamento para a esquerda no mundo todo: depois de 1953, com a morte de Stalin e a posterior divulgação dos crimes cometidos por seu regime, a volta para Marx significava tanto uma tentativa de auto-retificação da esquerda quanto um afronta à exclusividade exegética do Partido Comunista (Schwarz, 1998). Entretanto, é fundamental perceber que esse drama mundial, no caso do grupo, era filtrado por diversos problemas locais: tanto o "local" brasileiro, em épocas de hegemonia do nacionalismo e do desenvolvimentismo, quanto o "local" da própria Maria Antonia, onde, dado seu relativo isolamento das disputas imediatas da política nacional (ver Arruda, 2001), podia-se pensar em “...uma esquerda marxista sem chavão, à altura da pesquisa universitária contemporânea, aberta para a realidade, sem cadáveres no armário e sem autoritarismos a ocultar..." (Schwarz, 1998: 103). Alfredo Bosi aponta que essa articulação entre ciências sociais e dialética é sinal de uma desconfiança desses estudantes críticos contra a aliança entre técnica pretensamente neutra e opressão ideológica que marcava os esforços de desenvolvimento do país à época e que, em termos metodológicos e teóricos, haviam povoado o ensino de ciências sociais no país com receitas positivistas e funcionalistas. Dessa maneira, a imbricação entre sociologia e pensamento dialético, afirma Bosi, seria um problema de "política cultural vivida por toda uma faixa de cientistas sociais que pretendem fazer do seu conhecimento um instrumento eficaz de transformação" (Bosi, 2000 [1992]: 313).

Esse esforço intelectual de leitura sistemática da obra prima de Marx, como se vê, adquire um significado especial dadas as transformações pelas quais passava o Brasil à época. É crucial perceber que o "Brasil" não era apenas um tema a mais na agenda da maioria dos intelectuais participantes do Seminário: alguns deles elaboravam, então, suas monografias acerca de temáticas fundamentais da 
sociedade brasileira - as teses de doutorado de Cardoso (2004) e Novais (2005a) são testemunhos disso.

Mas, para além dos trabalhos de pesquisa individuais e das preocupações intelectuais e políticas apontadas por Schwarz, Milton Lahuerta sintetiza em três referências teóricas a "agenda local" que fornece o contraponto para a leitura do grupo. O primeiro é, como já indicado, o próprio Florestan Fernandes (e, sobretudo, o seu Fundamentos Empíricos da Explicação Sociológica, livro texto fundamental do que poderíamos chamar de primeira fase da Sociologia Paulista), quanto à sua tentativa de elaborar um método eclético que integrasse as várias tradições sociológicas (representadas principalmente por Durkheim, Marx e Weber). O segundo é o nacional-desenvolvimentismo e as teses dualistas formuladas pela Cepal. Por fim, os membros do Seminário contrapunham-se ao nacionalismo, tanto comunista quanto isebiano, que defendia a primazia da disputa entre nação e antinação naquele momento histórico (Lahuerta, 2005: 162-164). Somando-se a isso, não é exagero apontar que esses intelectuais estavam realizando, mesmo por vias pouco explícitas, um diálogo com a tradição dos "intérpretes" do Brasil, uma vez que também se preocupavam, por caminhos e com métodos diferentes, com o problema da formação da sociedade brasileira (ver Arruda, 2001: 298).

Quanto a estes "intérpretes", a influência de Caio Prado Júnior é primordial e apontada pelos próprios membros do grupo. Schwarz compreende que esse autor é uma exceção dentro do panorama do marxismo no Brasil até então, uma vez que o historiador paulista fugia tanto à vulgata comunista quanto do uso do marxismo como uma "referência filosófica de espíritos esclarecidos", sem grandes conseqüências para a vida política ou intelectual do país (Schwarz, 1998: 102). Fernando Novais aponta que a obra do historiador paulista é um marco na historiografia brasileira e latino-americana, de alguma forma sugerindo que ela antecede as obras do marxismo "mais criativo e crítico" que estariam sendo produzidas na América Latina nas décadas posteriores (Novais, 1986: 24-25) inclusive por membros do Seminário, poderíamos acrescentar.

A leitura que Novais realiza da obra Formação do Brasil Contemporâneo (2008 [1942]) é significativa daquilo que se buscou desenvolver no Seminário e que marcou a obra posterior de seus membros: trata-se de uma consideração da dialética marxista como "método" e, mais que isso, como o método científico por excelência. Novais aponta que a idéia de "sentido da colonização", presente desde 
o primeiro instante daquela obra, não é um ente que determina as várias manifestações da formação social da colônia: o "sentido" deveria ser entendido como a essência do fenômeno que se quer analisar; essência que explicaria as manifestações do fenômeno, ao mesmo tempo em que se explicaria por elas. Nessa forma de exposição dialética, inaugurada em nosso pensamento social e em nossa historiografia por Caio Prado, a exposição "deve pressupor, ou mesmo conter, os resultados analíticos da investigação, pois somente assim poderá recompor o andamento da realidade" (Novais, 1986: 18).

A primazia da dialética como método - certamente sob o impacto das considerações de Lukács sobre o "marxismo ortodoxo" (ver Lukács, 2003: cap. 1) é marcante em praticamente todos os trabalhos que se nutriram das reflexões deste seminário. Ela constitui o solo metodológico fundamental para o desenvolvimento daquela "intuição de Brasil" que Schwarz descreveu. Vemos aqui algo cuja importância não pode ser menosprezada: seguindo por uma veia bastante particular à tradição do marxismo dialético, os trabalhos que derivaram do Seminário resolveram os problemas suscitados pelos seus objetos (e, de forma geral, o problema da modernidade e do capitalismo no Brasil) levando em conta o próprio caráter contraditório desse objeto. Ou seja, ao utilizarem a expressão "marxismo dialético como método", não se pode entender que esses autores o estão propondo como um receituário metodológico universalizável, a partir do qual qualquer experiência da realidade social poderia ser abordada. Assim, método e objeto são mutuamente constitutivos, sendo que só faz sentido falar-se na primazia do método dialético uma vez que a própria realidade observada só poderia ser apreendida, em suas múltiplas manifestações e conexões de sentido, caso se considerasse seu caráter contraditório. A dialética a que esses autores recorrem, dessa forma, é a lógica imanente dos objetos da experiência sobre os quais eles se debruçam. Portanto, haveria nessa experiência intelectual coletiva uma via de mútua constituição entre uma "intuição de Brasil" e uma ciência social dialética, de maneira que método e objeto não fossem tidos como externos um ao outro ${ }^{98}$.

Talvez essa seja a grande contribuição desses autores à tradição marxista: a dialética, no capítulo brasileiro do marxismo, é avançada dadas as necessidades

\footnotetext{
${ }^{98}$ Como, aliás, propunham à época também outros autores da "fronteira" do pensamento crítico internacional - o que se observa, por exemplo, nas lições introdutórias de sociologia de Adorno (2008 [1968], sobretudo nas aulas 9 e 10).
} 
impostas pelo próprio objeto contraditório que é o capitalismo periférico e, particularmente, a forma como ele se realiza no Brasil ${ }^{99}$. O termo contradição não é fortuito: como se indicou inicialmente, essa "tensa dialética entre o mesmo e o outro" constitui, como vimos, um dado fundamental da formação social brasileira, que traz desafios insolúveis para uma consideração dela como entidade discreta ou a partir de esquemas dualistas, derivados de uma estrutura de referências eurocêntricas $^{100}$.

É na introdução a Capitalismo e Escravidão no Brasil Meridional (2003 [1962]) que o argumento da primazia do método dialético e uma análise do que ele significaria para as Ciências Sociais são afirmados de forma mais clara e contundente. Trata-se de um texto de extrema importância e que revela muito bem a função do "método dialético" na obra sociológica de Cardoso e em outros trabalhos relevantes do grupo. Essa complexa introdução só se justifica frente ao processo que o autor visa abordar - no caso, a constituição e desagregação da sociedade escravocrata no Rio Grande do Sul. É nesse texto também que as influências que Sartre e Lukács sobre a leitura da obra de Marx realizada no Seminário ficam mais claras, sobretudo no que se refere à posição da idéia de totalidade em uma análise dialética. A forma como Cardoso a define é particularmente importante, inclusive para o diálogo que proponho com os recentes estudos pós-coloniais. Cito:

"Na explicação dialética o conceito de totalidade é utilizado como um recurso interpretativo pelo qual se visa compreender, como Marx escreveu explicitamente no posfácio da Contribuição à Crítica da Economia Política, não a identidade, o padrão de invariância, mas as diferenças em

\footnotetext{
99 Nesse sentido, a obra desses autores pode ser aproximada a alguns clássicos do marxismo ocidental que se debruçaram sobre o processo de modernização de suas sociedades "não-clássicas". Gramsci é, sem dúvida, o principal nome (ver o capítulo anterior e Coutinho, 2000).

${ }^{100}$ Mais uma vez recorro a Paulo Arantes, que formula exemplarmente o que está em jogo nessa passagem da dualidade à contradição: "Como na tradição moderna espaço e reificação costumam andar juntos, não custa imaginar que relações internas que exprimem a natureza do processo são, ao contrário, visadas na sua verdade quando a forma do tempo passa para o primeiro plano - por certo não uma temporalidade qualquer, pois então não haveria meio de distinguir Bergson de Lukács, mas uma temporalidade que abra caminho para a negação interna e a contradição... Noto de passagem que, sem se dar ao trabalho de afinar tanto a conceituação, a revisão uspiana da dualidade baterá justamente na tecla da contradição" (Arantes, 1992: 48).
} 
uma unidade, tal como são engendradas numa totalidade determinada... A totalidade assim entendida pressupõe não apenas a existência de diferenças numa unidade, mas também a existência de 'conexões orgânicas' que explicam, ao mesmo tempo, o modo de inter-relacionamento existente entre as determinações que constituem as totalidades e o próprio processo de constituição das totalidades" (Cardoso, 2003: 29).

A definição de totalidade fornecida por Cardoso compraz tanto uma "totalidade longitudinal" (a história) quanto "latitudinal" (elucidação das relações contraditórias entre elementos que compõem uma realidade concreta) (ver Jay, 1984). Na forma de análise dialética apresentada por Cardoso, a partir da qual se procura recompor uma determinada "totalidade concreta", a função do analista é a busca das mediações pelas quais as determinações imediatas (e por isso abstratas, como a noção de atraso, poderíamos dizer) alcançariam inteligibilidade ao circunscreveremse em constelações globais (ver Cardoso, 2003: 32) (como a formação do capitalismo global e a posição de uma determinada sociedade) - sendo isso um exemplo do que chamamos anteriormente de "rotação de perspectiva". O concreto que se constitui dessa forma - como também tentou mostrar Novais em sua leitura de Caio Prado (carregada pelo espírito do Seminário, evidentemente) - aparece como o "ponto de chegada, quando é o verdadeiro ponto de partida: não há mediações sem o imediato e vice-versa" (Cardoso, 2003: 35). A totalidade recomposta pelo método dialético, nessa proposta, seria uma totalidade que não anularia a diferença, de forma que o particular é entendido como diferenciação do geral.

Dentre as várias conseqüências da análise de Cardoso a respeito do método dialético - entre as quais também poderíamos indicar seu potencial para uma análise da consciência dos atores sociais e para uma abordagem da mudança social de forma mais ampla -, creio que o espaço por ela aberto para uma reflexão sobre a dialética entre universal e particular é aquele com os maiores potenciais para a teoria crítica da modernidade periférica que, de forma mais ou menos coordenada, vai sendo elaborada pelos autores de que tratamos aqui.

É por ela também que podemos entender melhor porque Caio Prado Júnior é o "intérprete" retomado com maior vigor por esses autores. O historiador realiza uma 
espécie de "corte epistemológico" (na expressão posterior de Fernando Novais) ao descrever a formação social brasileira, desde a colonização, tendo em vista o processo mais amplo de expansão comercial européia. A formação social brasileira é um elemento específico daquela totalidade. É a partir dessa perspectiva mundial (ou seja, para além de um plano meramente nacional) que Caio Prado busca compreender as dimensões da vida social e da economia desenvolvidas na colônia. Esta é a passagem clássica em que essa relação é posta inicialmente (para depois, como nos lembra Novais, ser desdobrada em suas múltiplas determinações):

"No seu conjunto, e vista de um plano mundial e internacional, a colonização nos trópicos toma o aspecto de uma vasta empresa comercial, mais completa que a antiga feitoria, mas sempre com o mesmo caráter que ela, destinada a explorar os recursos naturais de um território virgem em proveito do comércio europeu. É este o verdadeiro sentido da colonização tropical, de que o Brasil é uma das resultantes; e ele explicará os elementos fundamentais, tanto no plano econômico como no social, da formação e evolução históricas dos trópicos americanos" (Prado Jr., 2008: 29; destaque no original).

O fundamental é perceber que a idéia de dialética, em Formação do Brasil Contemporâneo, tem duas dimensões que são paralelas: a forma de exposição e construção da totalidade concreta da colonização brasileira e, como estou tentando aqui destacar, a consideração das relações entre o todo e a parte, o universal (expansão marítima comercial européia) e o particular (dimensões da montagem da colônia). Com Caio Prado, em síntese, começa-se a formar uma "linhagem" (utilizando aqui de forma livre, novamente, as considerações de Brandão, 2007) que entende a formação brasileira a partir de suas relações com o capitalismo global, linhagem de que fazem parte, em grande medida, os trabalhos que aqui estão sendo analisados. Dessa forma, a colonização seria um fato pleno de conseqüências para nossa formação social não pela razão de termos sido colonizados por portugueses, mas exatamente pelo tipo de colonização aqui realizada e o momento histórico de realização dessa colonização - o próprio momento de formação do capitalismo. 
Mais do que uma interpretação inspiradora da história da colonização portuguesa nas Américas, essa "linhagem marxista e pós-colonial" - na forma como defini este último tipo de programa crítico no capítulo anterior - instaura uma forma de enxergar as faces do pretenso "atraso" periférico como momentos da modernidade e não como seu o seu outro. Cito Schwarz novamente: "O caminho fora aberto por Caio Prado Júnior, que na esteira aliás de Marx explicara a escravidão colonial como um fenômeno moderno, ligado à expansão comercial européia, estranho portanto àquela sucessão de etapas canônicas" (Schwarz, 1998: 105). A crítica à modernidade ou ao capitalismo periféricos como momento da crítica à modernidade ou ao capitalismo globais depende, como se vê, de uma consideração das formas de entrelaçamento entre as várias determinações dessa totalidade global.

Essa consideração das relações dialéticas entre universal e a particularidade da formação brasileira afastou a centralidade do questionamento acerca dos "Modos de Produção" que existiriam em cada etapa da formação brasileira. Com essa ruptura quanto à unidade de análise - que de nacional passa a ser global adquire maior relevância a compreensão das formas de relação entre as diferentes unidades do que a classificação de cada uma delas em um enquadramento de possibilidades históricas bem definidas ${ }^{101}$.

A ruptura da unidade de análise e a atenção para as articulações entre as diversas formas assumidas pelo capitalismo e pela modernidade é uma das marcas fundamentais, como se está tentando demonstrar, de todos os autores de que tratamos aqui. O filósofo José Arthur Giannotti formulou a questão com o maior nível de abstração, sintetizando de forma bastante exemplar aquilo que seria materializado nas várias análises dos outros membros do Seminário. No artigo “Notas sobre a categoria 'Modo de Produção' para uso e abuso dos sociólogos” (1976), Giannotti busca fornecer uma resposta, pelas vias da dialética marxista, para o problema dos modos de produção, tão em voga na época.

Giannotti realiza uma crítica geral da definição dos modos de produção pela enumeração dos predicados que caracterizariam cada um deles. Em outros termos,

101 Isso explica a enorme oposição existente entre o marxismo dialético que se desenvolve a partir do seminário e a onda do estruturalismo que se tornaria, provavelmente, majoritária no marxismo acadêmico a partir de meados da década de 1960, sobretudo a partir dos trabalhos de Althusser. Para uma discussão sobre a idéia de Modos de Produção aplicada à realidade brasileira e as alternativas a essa forma de teorização, ver Love (1998, parte III). 
a síntese das várias determinações que sumarizaria um conceito não se faz por essa justaposição de diversos predicados, mas por um processo reflexionante, em que resultados se convertem em pressupostos e vice-versa (Giannotti, 1976: 163). Dessa forma, o relevante para o estudo dos modos de produção seria a análise de como "relações de produção, relações sociais mediadas por coisas trabalhadas, se instauram e se mantêm graças a um processo que vem repor sua própria realidade" (Giannotti, 1976: 163). É a partir da análise dessas relações de produção que o conceito ganha concretude, nas múltiplas manifestações históricas possíveis e, sobretudo, abarcando a diversidade das formas de relação entre particularidades e a totalidade do modo de produção. A consideração da diversidade e a centralidade de uma abordagem acerca das formas de entrelaçamento entre as várias manifestações de uma totalidade concreta, abertas por essa forma de análise, são especialmente relevantes no caso do capitalismo, como indica Giannotti:

\begin{abstract}
"Repondo-se a todo instante, individualizando-se graças a seu próprio movimento circular, além de fagocitar modos periféricos, além de instaurar uma história universal por meio da destruição das histórias particulares, o capital está pois criando formas de organização do trabalho que não se efetivam sob as estritas condições de extração da maisvalia... Todos sabemos que o capital comercial forja o sistema colonial, isto quando o capital em geral existe apenas em germe, como processo objetivo que resultará na revolução industrial... Em suma, a circularidade do capital se perfaz configurando um círculo de círculos. Até quando estamos autorizados a chamar cada um desses círculos um modo de produção? A pergunta pela denominação perde importância quando se privilegia a lógica da constituição das circularidades" (Giannotti, 1976: 167).
\end{abstract}

Um círculo de círculos ou uma totalidade de totalidades: a "lógica da constituição das circularidades", ou seja, o inter-relacionamento entre as várias formas assumidas pelo capital em sua manifestação global, adquire primazia sobre um exercício classificatório. Além disso, em termos mais concretos, esse tratamento dialético do capitalismo moderno permite a consideração de um fenômeno como a escravidão como um dado desse capitalismo e dessa modernidade - e, como veremos, a própria crítica desta. 
Certamente é Fernando Novais quem irá tirar as maiores conseqüências dessa forma de pensar a história brasileira em suas relações com a história da modernidade capitalista, em uma explícita incorporação crítica do trabalho de Caio Prado Júnior a partir dos desdobramentos daquela "intuição de Brasil" que surge no Seminário. Na historiografia e nas Ciências Sociais brasileiras, o trabalho de Novais Portugal e Brasil na Crise do Antigo Sistema Colonial (1979) é aquele que desenvolve o mais audacioso argumento acerca do papel fundamental desempenhado pela colonização nas Américas para o desenvolvimento do capitalismo na Europa. É interessante observar que, em suas análises da obra de Caio Prado, Novais tenta demonstrar que aquele historiador haveria "ficado no meio do caminho" em suas considerações sobre a forma como a colonização do Brasil se situaria no panorama mundial. A questão, aponta Novais, não deveria se restringir às relações entre o estabelecimento da Colônia e a expansão comercial européia: um passo à frente seria a busca das articulações entre a exploração colonial e a transição do feudalismo ao capitalismo (Novais, 1986: 20) ${ }^{102}$. O autor retira as maiores conclusões da idéia de "acumulação primitiva" em Marx, buscando uma imagem de conjunto que articulasse o geral (formação do capitalismo) e o particular (formação do Sistema Colonial) ${ }^{103}$. O Sistema Colonial - o conjunto de mecanismos e relações efetivas que integra e articula a colonização com as economias centrais européias - é o componente a partir do quais as várias manifestações da colonização se tornam inteligíveis (ver Novais, 2005a [1979]: 70) e a partir do qual se realizaria o "sentido profundo da colonização".

Como se sabe, o tráfico negreiro adquire uma posição central no processo de acumulação primitiva na Europa. Esse talvez seja o veio mais polêmico, porém igualmente aquele com maior potencial crítico, entre aqueles explorados por Fernando Novais. Em um sistema montado para promover a acumulação primitiva

102 Além do trabalho de Caio Prado e da leitura conjunto de Marx no seminário d’O Capital, a influência das análises do historiador caribenho Eric Williams sobre Fernando Novais é fundamental, como o próprio autor deixa claro. Além disso, a semelhança do percurso trilhado por Novais e por seus colegas ligados aos "Estudos da Dependência" e aquele que será realizado posteriormente por Immanuel Wallerstein é digno de nota, apesar das distinções entre eles.

103 “....a colonização do Novo Mundo na Época Moderna apresenta-se como peça de um sistema, instrumento da acumulação primitiva da época do capitalismo mercantil. Aquilo que, no início dessas reflexões, afigurava-se como um simples projeto, apresenta-se agora consoante como processo histórico concreto de constituição do capitalismo e da sociedade burguesa. Completa-se, entrementes, a conotação do sentido profundo da colonização: comercial e capitalista, isto é, elemento constitutivo no processo de formação do capitalismo moderno" (Novais, 2005a: 70). 
na metrópole, o tráfico de cativos africanos, comandado por mercadores europeus, instaura um setor de comércio de grande importância - enquanto, como observa Novais, o aprisionamento de indígenas geraria um mercado apenas interno à colônia. A conclusão é contundente: "Paradoxalmente, é a partir do tráfico negreiro que se pode entender a escravidão africana colonial, e não o contrário" (Novais, 2005a: 105). O potencial dessas descobertas para uma crítica ao capitalismo e à modernidade, presente na reflexão de diversos membros do Seminário, é exposta já por Novais:

\begin{abstract}
"E assim a Europa pôde contemplar o espetáculo deveras edificante do renascimento da escravidão, quando a civilização Ocidental dava exatamente os passos decisivos para a supressão do trabalho compulsório, e para a difusão do trabalho 'livre', isto é, assalariado. Assim, enquanto na Europa dos séculos XVI, XVII e XVIII transitava-se da servidão feudal para o trabalho assalariado, que passou a dominar as relações de produção a partir da revolução industrial, no Ultramar, isto é, no cenário da europeização do mundo, o monstro da escravidão mais crua reaparecia com uma intensidade e desenvolvimento inéditos" (Novais, 2005a: 98).
\end{abstract}

Novais expõe a metrópole se desnudando na colônia: ela - colônia, depois periferia do sistema-mundo capitalista em formação - revela a natureza do processo civilizador europeu. No rastro da idéia benjaminiana, a tese de Novais e os outros trabalhos que desenovelaram aquela intuição de Brasil procuraram mostrar que a história da formação da periferia é o documento de barbárie sem o qual não se entende o documento de civilização composto desde a Idade Moderna. Este ponto crítico fornecido pelo ponto de vista periférico comporta uma estrutura de referências segundo a qual as "anomalias" periféricas expõem as fraturas constitutivas da "normalidade moderna". O trabalho do historiador, lido em conjunto com os outros trabalhos relevantes que beberam de uma visão metodológica e histórica semelhante, ajuda a construir coletivamente uma história do Brasil que não é mais nacional, uma vez que o eixo de análise é internacional. Trata-se, nas palavras nada exageradas de Paulo Arantes, de um verdadeiro exercício de "desprovincialização da história do país" (Arantes, 1992: 89) - algo bastante 
anterior, mas inteiramente coerente, à proposta de revisão histórica proposta por um crítico pós-colonial como Dipesh Chakrabarty (ver início do capítulo 2) e afinado com uma consideração contemporânea da colonialidade da modernidade.

A exposição de Novais caminha da parte ao todo e do todo à parte: Novais não realiza uma busca dos elementos que "determinam" externamente a colonização e não se restringe a uma análise dos processos internos à colônia, mas constrói reflexivamente as formas de articulação entre o Sistema Colonial e o capitalismo em formação - uma busca pela lógica da mútua constituição de cada uma dessas circularidades, nos termos de Giannotti. E, para além disso, Novais esboça uma preocupação que também estará presente nas principais obras de Cardoso e nos "Estudos de Dependência" por ele encabeçados: o historiador preocupa-se, em diversos momentos, em mostrar que a acumulação realizada pela exploração colonial não é suficientemente captada por uma idéia de "exploração da colônia pela metrópole": nesta, haveria uma camada social específica que se beneficiaria do processo - a burguesia mercantil -, assim como na colônia haveria uma camada que se beneficiavam da participação no Sistema colonial - o senhoriato (Novais, 2005b). Evidentemente, Novais está descrevendo a montagem de uma economia colonial mercantil, escravista e com acumulação externa (ver Novais, 2005a: 145), mas observando que existem grupos sociais que se beneficiam assimetricamente dessa acumulação primitiva em processo. Indicando os agentes fundamentais do processo de montagem desse sistema colonial, Novais consegue escapar de uma denúncia de teleologia, da mesma forma como escaparia de qualquer acusação de determinismo unilateral do externo sobre o interno.

Os diversos aspectos que Novais desenvolve na análise do Sistema Colonial serão, também, em grande medida, as balizas para as análises sociológicas de Cardoso e lanni, desenvolvidas paralelamente ao trabalho do historiador, naquilo que alguns autores chamaram de "Sociologia da Dependência"104. Voltada para os problemas do desenvolvimento econômico e social de seu tempo, a obra desses sociólogos pode ser entendida, em grande medida, como uma tentativa de compreensão das formas pelas quais o desenvolvimento repõe as relações sociais forjadas pela situação colonial. Em outros termos, essa "sociologia da

\footnotetext{
${ }^{104}$ As relações entre os estudos da dependência e a análise histórica de Novais não deixaram de ser notado pelos críticos desta, como se observa exemplarmente no trabalho de Flamarion Cardoso (1980).
} 
dependência", de forte inspiração dialética, volta-se à realização de um programa crítico de compreensão da especificidade das formações periféricas pós-coloniais sobretudo latino-americanas - e dos potenciais e bloqueios ao desenvolvimento derivados dessa posição específica no capitalismo mundial ${ }^{105}$. Talvez não seja mais preciso acrescentar que o estudo dessas sociedades periféricas já se efetiva como o estudo do próprio desenvolvimento do capitalismo - desigual e combinado, na fórmula marxista que se torna clássica na obra de Trotsky.

Evidentemente, os estudos que constituíram esse programa sociológico crítico trataram dos mais diferentes aspectos do desenvolvimento dessas sociedades, como que compondo uma interpretação coletiva do desenvolvimento das sociedades dependentes latino-americanas e, mais especificamente, da brasileira. Creio que é produtivo pensar essa "interpretação coletiva", de fronteiras pouco definidas, presente na obra desses sociólogos - mas também na história colonial de Novais e nos estudos literários de Roberto Schwarz - como as várias materializações daquela "intuição de Brasil" gerada no Seminário d'O Capital e gestada nos vários espaços intelectuais e acadêmicos que perfaziam aquela "ambiência criativa" a que já nos referimos.

Um exemplo dessas várias materializações é o estudo de Octavio lanni sobre o papel do estado no desenvolvimento do capitalismo industrial brasileiro. Conforme se poderia esperar, dadas as suas referências teóricas e o enquadramento que foi aqui destacado até o momento, a análise da industrialização brasileira realizada por lanni busca a construção da totalidade dos processos - tanto do próprio capitalismo em sua expansão desigual e combinada quanto das várias transformações por que a sociedade brasileira passava desde o início do século $X X$. O que há de mais interessante em termos metodológicos na abordagem de lanni é a sua tentativa de mostrar como as dualidades historicamente mobilizadas para a compreensão da modernização brasileira não davam conta da constituição da concretude desse

\footnotetext{
${ }^{105} \mathrm{Em}$ trabalho posterior à sua tese, Novais aponta as formas como esses trabalhos se relacionam: "Também aqui [fase da industrialização, JHB], como nos períodos anteriores, o movimento real de constituição da formação social - isto é, da estratificação e da articulação das classes - só se pode apreender na tensão entre o geral e o particular, que constantemente se negam e integram-se: a dinâmica do capitalismo moderno e monopolista, integrando as antigas áreas coloniais nos circuitos da acumulação e as nações em desenvolvimento, posicionando-se nesse contexto. Daí a forma específica que assume nesses países - como o Brasil - a vida social, econômica e política: nos termos de Fernando Henrique Cardoso (cujas análises estão presentes nos vários passos desta exposição), capitalismo dependente-associado" (Novais, 2005b: 153).
} 
processo. lanni, dito de outro modo, não analisa apenas as formas de interpenetração entre "arcaico" e "moderno" próprias à modernização em uma sociedade periférica como a brasileira. Sua crítica busca atingir um alcance maior a respeito do uso de uma lógica dualista na compreensão desse processo.

Uma das dualidades de imediato postas em xeque por lanni - de forma bastante próxima àquilo que também estava sendo à época realizado por Cardoso e Novais - é a dicotomia entre externo e interno - ou, nos ternos do debate político à época, entre nacionalismo e imperialismo. lanni busca mostrar que a industrialização no Brasil, em vez de exigir uma indispensável ruptura com os capitais internacionais - como pregava, sobretudo, o Partido Comunista brasileiro estava sendo encaminhada de forma a apoiar-se na associação com o capital internacional. Nenhuma aberração do real, parece dizer lanni: "O capitalismo é um só. Quando a industrialização se impõe no Brasil, esta se faz em conjugação e no âmbito do capitalismo internacional" (lanni, 2004 [1965]: 67).

A crítica ao dualismo adquiriu uma importância fundamental na obra desses autores e em outros trabalhos críticos posteriores que estabeleceram alguma comunicação com eles - sobretudo em Crítica à Razão Dualista, de Francisco de Oliveira e Cativeiro da Terra, de José de Souza Martins (ver Arantes, 1992 e Costa, 1978). Cito longamente diversos trechos da argumentação de lanni, uma vez que eles sintetizam com clareza a crítica ao dualismo que é avançada em diversos dos trabalhos praticantes daquele método dialético:

"O conceito de dualidade retira a historicidade da história, tomando o objeto presente em sua existência manifesta... Apenas se afirma a existência do problema, sem que o diagnóstico recomponha a teia de significações que reproduzem a realidade em toda a sua riqueza. Em conseqüência, os fenômenos guardam distância entre si, como se fossem exteriores uns aos outros" (lanni, 2004: 73; destaque meu); "Além do mais, a visão dualista da realidade é abstrata e apenas descritiva. Ela não se apóia na análise das continuidades ou articulações do sistema, mas, ao contrário, na afirmação de suas desigualdades. Ela se apóia na exploração descritiva de apenas uma face da realidade, em sua superfície. E toma as desigualdades como significativas em si, deixando de apanhar seu significado 
integrativo... Finalmente, é uma concepção mecânica da realidade que está na base da teoria das dualidades. Ao seccionar o sistema em arcaico e moderno, urbano e industrial, interno ou externo ou fechado e aberto, essa concepção atribui à realidade as categorias abstratas e subjetivas que fundam a oposição entre o bem e o mal... Na base da teoria das dualidades está um maniqueísmo que só se sustém devido à sua facilidade" (Ianni, 2004: 75-76; destaques meus)

Não poderia ser mais clara a vinculação dessa crítica aos dualismos à apresentação geral sobre as formas de análise integradas de cada uma das esferas do capitalismo, apresentada por Giannotti. Ela é uma demonstração de como a tentativa do desenvolvimento de uma Ciência Social aberta à análise da contradição possui um momento de desconstrução de antinomias ou polarizações abstratas de conceitos que, vistas a partir das experiências sociais periféricas, perdem qualquer efetividade.

Essa desconstrução de polaridades abstratas estará presente em todos os trabalhos aqui referidos, desde Capitalismo e Escravidão no Brasil Meridional, publicado em 1962, no qual Cardoso já avança em seu programa crítico, ao mostrar exatamente as formas de integração de elementos que, vistos a partir de uma narrativa eurocêntrica da história, seriam incompatíveis. O livro já constitui uma primeira tentativa interna ao grupo de mostrar como escravidão e capitalismo não são incompatíveis por princípio, sendo que o segundo precisou da primeira para desenvolver-se - uma consideração que desvela uma "história outra do capitalismo", só apreensível a partir das margens desse sistema.

A dimensão sociológica daquela dialética encontrará máxima expressão no trabalho de Fernando Henrique Cardoso, do início da década de 60 até meados da década de 70. Em suas maiores análises sociológicas, é possível perceber uma constante preocupação com a reconstituição de totalidades concretas, referidos historicamente. Isso parece ser característica advinda não somente daquela leitura coletiva da obra de Marx, mas também constituiu uma preocupação geral de grande parte da "Sociologia Paulista"106 - assim como a preocupação em mobilizar outros

106 Para um exemplo fundamental, ver a análise de Martins sobre a formação agrária brasileira, sobretudo em Martins (2004); para uma análise geral desta questão, ver Bastos (1999). 
autores e tradições teóricas para além do marxismo, como reflexões de Weber e os trabalhos da Cepal.

Alguns dos principais trabalhos de Cardoso podem ser lidos como uma tentativa geral do questionamento de categorias e pressupostos históricos forjados em um contexto europeu para a compreensão das dinâmicas sociais em países periféricos. O trabalho Empresário Industrial e Desenvolvimento Econômico no Brasil é exemplar nesse aspecto. Nele, Cardoso realiza aquela que talvez seja a mais importante crítica acadêmica à idéia da existência de uma "burguesia nacional" no Brasil, esta entendida como um setor social preocupado em promover o desenvolvimento e a industrialização em bases nacionais, em oposição à posição das oligarquias agrárias, aliadas permanentes do capital internacional. Cardoso tem em mente uma série de alvos, desde o partido comunista (participante de uma espécie de aliança desenvolvimentista), o Iseb (por seu nacionalismo e pela tentativa de elaborar uma análise sociológica do Brasil como se ele fosse um "fato singular discreto" - conforme Cardoso, 1972 [1964]: 47), à sociologia da modernização, sobretudo como proposta por W. W. Rostow, com suas etapas de desenvolvimento bem definidas e sua proposição de articulações e papéis sociais descolados de contextos históricos.

Em vez de utilizar esses modelos abstratos, próprios a essas teorias sociológicas em voga em seu tempo (incluindo a sociologia de Parsons), Cardoso propõe que se avance na reconstrução de situações concretas, uma reconstrução que exige a reflexão acerca das estruturas que explicariam o desenvolvimento e que condicionariam a passagem de um tipo de dinâmica a outro ${ }^{107}$. A constituição dessas totalidades concretas exige uma consideração - e estamos aqui em terreno conhecido - das relações entre componentes estruturais internos e externos. Dessa forma, ganharia significado mundial as noções de "atraso" ou, mais especificamente, de subdesenvolvimento: "A noção de sociedade subdesenvolvida só se torna significativa quando há uma referência implícita a uma relação determinada entre um tipo particular de sociedade com outra que é 'desenvolvida'” (Cardoso, 1972: 73). Essa relação determinada passa por uma consideração,

107 Como explica em um artigo posterior, essa passagem para a concretude exige a substituição de modelos de análise baseados em determinações gerais e abstratas por outro que vise a situar concretamente cada momento significativo de modificação da produção capitalista internacional, mostrando como se dá a rearticulação das classes sociais, da economia e do Estado em situações particulares (Cardoso, 1979: 127). 
conforme Cardoso, da divisão internacional do trabalho e do tipo de dominação que Ihe é correlato, e por uma consideração do subdesenvolvimento como uma forma do desenvolvimento: "É preciso, pois, partir da análise das relações básicas entre essas duas formas de sociedade que, em conjunto, exprimem o modo capitalista de produção para compreender cientificamente o processo de desenvolvimento no 'mundo ocidental'” (Cardoso, 1972: 73).

Assim, particularmente quanto ao objeto de que trata nessa pesquisa, Cardoso não deixa de lembrar que a análise da burguesia no Brasil deve ater-se às especificidades do desenvolvimento de uma economia periférica, onde o empreendedor não repetiria a via "clássica" de formação do capitalismo; além disso, o potencial desse desenvolvimento seria condicionado pela situação do mercado mundial e pelos níveis desiguais de desenvolvimento técnico (Cardoso, 1972 [1964]: 46). A consideração dessa especificidade leva a conseqüências analíticas e políticas extremamente distintas daquelas que Cardoso pretende criticar. $O$ argumento que vai sendo revelado pelo sociólogo é o de uma espécie de "drama periférico", em que modernidade e atraso articulam-se de formas diversas, em todas as fases da "modernização". O que se expõe, particularmente, é a inadequação da categoria de uma burguesia nacional: essa "camada", de que tanto se esperava, aliava-se, sempre que preciso, com os setores agrários e oligárquicos mais "arcaicos" ou com o capital internacional, sem que, na prática, isso fosse sinal de qualquer grande contradição; na sociedade brasileira, conviveriam valores estamentais e de classe - não ladeados de forma dualista, mas compondo, por uma simbiose estrutural, a modernidade brasileira.

Cardoso demonstra, poderíamos dizer, a dissolução das categorias mesmas de "tradicional" e "moderno", vistas a partir do capitalismo periférico: "À crescente expansão do mercado e, conseqüentemente, ao aumento de poderio econômico da burguesia industrial, não tem seguido, pelo menos no mesmo ritmo, a desagregação da antiga ordem político-social pré-industrial. A burguesia industrial se acomoda em larga medida à dominação tradicional” (Cardoso, 1972: 181).

Este trabalho de Fernando Henrique Cardoso firma grande parte das bases daquilo que irá se constituir, nos anos seguintes, como uma das versões da "Teoria da Dependência" - ou dos "Estudos de Dependência", como prefere Cardoso (1979 e 1977). O principal livro que marca esses estudos, Dependência e Desenvolvimento na América Latina (2004 [1968]) (escrito conjuntamente com o 
economista chileno Enzo Faletto), parte de considerações e dos pressupostos metodológicos que guardam grande proximidade com o Empresário Industrial..., seja na crítica à sociologia da modernização, na desconstrução de perspectivas dualistas e da transposição das análises sobre o "capitalismo clássico" para a análise de sociedades periféricas, ou na compreensão integrada do desenvolvimento das economias centrais e periféricas, tendo em vista sobretudo as formas como se instituem estruturas de dominação internas e externas aos estados dependentes $^{108}$.

Com essa consideração das relações contraditórias entre grupos internos e externos, essa vertente ("dialética", digo novamente) dos estudos da dependência procura realizar uma espécie de atualização das análises marxistas clássicas do imperialismo para o período em que as economias periféricas passam por um processo de industrialização ou já se industrializaram em alguma medida (ver Cardoso, 1979: 133). Mas uma atualização que dedica atenção especial para as dinâmicas internas aos estados periféricos - algo que só é tratado marginalmente em trabalhos como os de Lênin, Hilferding ou Rosa Luxemburgo.

'The 'movement' that had to be understood, then, was that deriving from the contradictions between the external and the internal, viewed in this complex fashion and summed up in the expression 'structural dependency'. If imperialism was embodied in the penetration of foreign capital (invasions by Americans in the Caribbean, by the English in South America, etc.), it also implied a structural pattern of relations that 'internalized' the external and created a state which was formally sovereign and ready to be an answer to the interests of the 'nation', but which was simultaneously and

\footnotetext{
${ }^{108}$ Este último é um aspecto bastante relevante do trabalho de Cardoso, que diferencia sua obra daquela dos principais autores "dependentistas" que estavam produzindo seus principais trabalhos no mesmo período nos Estados Unidos - sobretudo André Gunder Frank, a quem Cardoso dirige críticas duríssimas (Cardoso, 1977). Como já apontamos no capítulo anterior, a estrutura de composição da totalidade das relações sociais que caracteriza as situações de subdesenvolvimento exige, para ele, não apenas um tratamento da posição de um determinado país no mercado mundial, mas, sobretudo, da dinâmica de classes interna e externa que constituiu e que garante a manutenção dessa situação de dependência. Na maior parte desse livro, Cardoso e Faletto dedicam-se a estudar as modificações das estruturas de dominação que garantem 0 desenvolvimento desses estados em diferentes períodos.
} 
contradictorily the instrument of international economic domination" (Cardoso, 1977: 13)

Vemos aqui, nos termos de Cardoso, aquilo que Boaventura de Sousa Santos expressou como o entrelaçamento entre "guerra civil" e "Baía dos Porcos", no estabelecimento dos esquemas de dominação no capitalismo periférico.

Em "Classes Sociais e História: Considerações Metodológicas", Cardoso realiza uma importante síntese sociológica das leituras da realidade periférica, particularmente brasileira, que animaram os diversos trabalhos a que nos referimos aqui. Trata-se de um artigo bastante denso e rico de possibilidades, uma vez que nele se apresenta uma espécie de revisão dos desafios que a consideração da realidade periférica coloca aos mais diversos aspectos da teoria sociológica e, diríamos, para a teoria da história que orienta os principais esforços de teorização dessa disciplina. Creio que o que Cardoso realiza aí é um verdadeiro exercício de demonstração sociológica da colonialidade da modernidade capitalista, a partir de uma perspectiva periférica. Cardoso esforça-se por mostrar que a compreensão de uma determinada realidade histórica e, particularmente, do modo de produção capitalista, exige atenção para as formas como os diversos elementos organizam-se em um todo particular.

\footnotetext{
"Sendo assim, pensar em termos do modo de produção capitalista o problema das classes e da política na América Latina não significa isolar neste lado do mundo as mesmas características do proletariado e da burguesia industrial inglesas, nem recomeçar a história pela singularidade irredutível da formação social capitalista na periferia. Ambas as perspectivas são falaciosas. É preciso mostrar, simultaneamente, que a periferia não existe sem o centro e que este - desde que exista um modo de produção colonial é também este modo de produção que, por outro lado e ao mesmo tempo, é oposto ao modo capitalista industrial de produção. É e não é, como se propõe na lógica dialética" (Cardoso, 1975: 106; destaque no original).
}

Este realização periférica específica do capitalismo - que, como também aponta Giannotti, só pode ser entendido como um modo de produção subsidiário 
(modo de produção colonial, por exemplo) caso se mostre sua articulação interna ao modo de produção capitalista que o engloba - permite a compreensão da escravidão na periferia, mais uma vez (e não por menos, dada a significação do problema para a formação social brasileira), ou o comportamento dos senhores de escravos como problema próprio ao capitalismo e à modernidade. A análise que Cardoso faz deste setor da sociedade escravista brasileira é digno de nota, uma vez que demonstra a contradição como forma de ser fundamental de uma sociedade periférica. O sociólogo aponta que esses senhores de escravos constituíam uma categoria social cuja existência presumia a contradição entre as formas sociais de trabalho próprias à produção colonial e o destino mercantil dos resultados dessa produção - uma contradição derivada do modo como se inseriam no sistema capitalista mundial: "Demônios bifrontes, se se quiser, duplamente contraditórios, excrescências necessárias para o avanço, no centro do sistema, da acumulação e da potenciação das forças produtivas; entraves estruturais para a etapa seguinte do desenvolvimento gerado pela acumulação que eles em parte propiciaram" (Cardoso, 1975: 111).

Para vislumbrarmos outras dimensões desse programa crítico interdisciplinar, é relevante apontar que esse tipo de contradição próprio às formas de efetivação de classes sociais e da própria experiência social na periferia seria explorado por Roberto Schwarz, sobretudo em sua análise clássica das obras de Machado de Assis (Schwarz, 2000 [1977] e 2000 [1990]). Como aponta Paulo Arantes (1992), Schwarz tira conseqüências estéticas daquela "intuição de Brasil", podendo desenvolver uma importante leitura dialética da vida cultural brasileira no século $\mathrm{XIX}^{109}$, em grande comunicação com as análises históricas de Novais e com as descobertas sociológicas de Cardoso e lanni - sem nos esquecermos de sua companheira de "sociologia paulista", Maria Sylvia de Carvalho Franco, autora de Homens Livres na Ordem Escravocrata (1983). A tese que se desenvolve coletivamente, que trata do caráter funcional do "atraso" na reprodução da sociedade moderna na periferia e seus desdobramentos no caso brasileiro, é tomada por Schwarz como ponto de partida para uma crítica cultural desprovincializadora, uma vez que ela permitiria inscrever na ordem internacional aquilo que parecia nos afastar dela (Schwarz, 2000 [1990]: 13). Ou seja, a partir

${ }^{109}$ E também do século XX, como atesta, por exemplo, sua importante análise da cultura brasileira nos primeiros anos da ditadura militar (ver Schwarz, 2008 [1978]). 
daquele diagnóstico acerca do travejamento sociológico das sociedades periféricas em relação com a modernidade capitalista global, o crítico busca resolver a antinomia há muito presente nos debates culturais no país, que colocava ao crítico uma espécie de escolha entre nacionalismo ("tudo nos seria original") e cosmopolitismo ("tudo aqui é cópia").

Em termos de método de análise literária, o que Schwarz busca realizar é uma análise dialética da cultura brasileira. Para isso, além de avançar um diálogo e apropriações do que ele chama de "tradição contraditória" (Lukács, Brecht, Benjamin e Adorno, além da inspiração do próprio Marx), Schwarz busca uma filiação com o método de Antonio Cândido, sobretudo presente em sua análise clássica do romance Memórias de um Sargento de Milícias (1854), de Manuel Antonio de Almeida. Em "Dialética da Malandragem" (1970), Cândido teria inaugurado, no juízo de Schwarz (ver 2006 [1987]), a análise dialética da cultura no pensamento brasileiro; o procedimento fundamental que vem de Cândido é a investigação da "função exercida pela realidade social historicamente localizada para constituir a estrutura da obra - isto é, um fenômeno que se poderia chamar de formalização ou redução estrutural dos dados externos" (Cândido, 1970: 75; destaque meu). Schwarz adverte que a crítica inaugurada por Cândido no Brasil parte de uma não separação entre o estético e o social, uma vez que a forma é entendida como síntese do movimento histórico ${ }^{110}$. Dessa maneira, a análise da cultura passa a ser mecanismo de elucidação da estrutura social, assim como as ciências sociais e a história iluminam a apreensão da forma pelo crítico.

Esse método de crítica cultural será levado a cabo, de forma mais acabada, na importante leitura que Schwarz faz do livro Memórias Póstumas de Brás Cubas (1880), de Machado de Assis. Em Um mestre na periferia do capitalismo (2006 [1990]), Schwarz descreve minuciosamente as maneiras como Machado de Assis

\footnotetext{
110 "Noutras palavras, trata-se de ler o romance sobre fundo real e de estudar a realidade sobre fundo de romance, no plano das formas mais que dos conteúdos, e isto criativamente... o crítico tem de construir o processo social em teoria, tendo em mente engendrar a generalidade capaz de unificar o universo romanesco estudado, generalidade que antes dele o romancista havia percebido e transformado em princípio de construção artística" (Schwarz, 2006: 140; destaque no original). Como aponta Cevasco (2003: 186), a crítica literária, nessa acepção, deixa de enxergar-se como a busca da significação atemporal, mas busca aquilo que as obras dizem sobre seu tempo e sobre a sociedade em que vivemos. O impacto da obra de Schwarz é exemplar nesse aspecto: suas análises acerca da sociedade brasileira do século XIX, engendradas, sobretudo, em seus estudos da obra de Machado de Assis, ainda funcionam como um dos pontos de partida cruciais para debates históricos e sociológicos sobre aquela sociedade.
} 
teria erigido a "volubilidade" (tanto na prosa quanto no enredo) como forma organizadora desse romance. Volubilidade revelada, por exemplo, pelas mudanças sucessivas de tom e opinião do narrador e pela sua circulação no interior da sociedade brasileira do século XIX. O mais relevante para nossas observações aqui é mostrar como Schwarz consegue compor um Machado de Assis crítico das relações sociais do Brasil de sua época, uma vez que esse princípio formal da volubilidade relaciona-se à forma de ser da burguesia brasileira no século XIX, funcionando a partir de um código de ética que compunha norma burguesa e favor, ou liberalismo e escravismo. A volubilidade é a forma que Machado encontra de representar uma situação em que as idéias liberais não se podiam praticar, mas ao mesmo tempo eram indescartáveis (Schwarz, 2000b [1977]: 25).

A volubilidade seria, portanto, uma maneira de reduzir formalmente 0 antagonismo de classes em sua forma particular ao Brasil (Schwarz, 2000: 62) - ou seja, um país periférico em que - aponta Schwarz remetendo a Trotsky - pelo mecanismo do "desenvolvimento desigual e combinado do capitalismo", a causa última de sua formação social "absurda" "está nos avanços do capital e na ordem planetária criada por eles, de cuja atualidade as condutas disparatadas de nossa classe dominante são parte tão legítima e expressiva quanto o decoro vitoriano" (Schwarz, 2000: 39; destaque no original) ${ }^{111}$. Dessa maneira, a construção literária pode ser enxergada como um instrumento de crítica global da modernidade, vista de suas margens:

\begin{abstract}
"Machado de Assis pormenorizava e apurava a dimensão não burguesa da existência burguesa no Brasil, e estendia ao âmbito da convenção artística, na forma generalizadora da transgressão... Em conseqüência, escravismo e clientelismo não são fixados apenas pelo lado óbvio, do atraso, mas também pelo lado perturbador e mais substantivo de sua afinidade com a tendência nova. Esta 'modernidade', que se poderia prestar para álibi de classe, no universo machadiano entretanto não alimentou ilusões: ela só the aumenta a miséria, pois, sem elogiar o atraso, desqualifica o progresso
\end{abstract}

\footnotetext{
111 Não é exagero apontar que o termo "atualidade", destacado por Schwarz, nos remete aos problemas tratados várias vezes até aqui acerca da temporalidade global de uma história narrada a partir das margens, como nos alertam autores como Homi Bhabha, Boaventura de Sousa Santos e Timothy Mitchell.
} 
de que ele faz parte. Uma posição crítica de altura difícil de igualar" (Schwarz, 2000: 185-186).

A crítica de Machado, via Schwarz, adquire dimensões de crítica ao capitalismo moderno global, em suas múltiplas realizações; dito de outra maneira, Schwarz, informado pelo diagnóstico sociológico de que vim tratando (e, evidentemente, ampliando-o), propõe a leitura de Machado de Assis como um crítico não apenas de nossas elites oitocentistas, mas, a partir delas, do próprio universalismo burguês, que nos países periféricos teriam suas "horas de verdade" (Schwarz, 2000: 217). Pelas vias da volubilidade, se avançaria em direção a uma desprovincialização do Brasil - uma vez que os mecanismos desiguais de inserção do país nos meandros do capitalismo global é que dariam sentido aos comportamentos de classe exemplificados por Brás Cubas, um típico representante da elite brasileira do período. Contudo, fazer sentido da ação dessa burguesia local exige uma consideração sobre as articulações globais que configuraram a forma de ser colonial e pós-colonial brasileira; por esses caminhos, localizar o Brasil no Ocidente passa por emitir um outro olhar sobre esse Ocidente, a partir dessa experiência periférica.

Por essa lente, Machado de Assis se revela como um "autor pós-colonial" exemplar, sobretudo no sentido que tratamos o termo no capítulo anterior ${ }^{112}$, e Schwarz, no mesmo sentido, um crítico igualmente pós-colonial ${ }^{113}$ : ambos expressariam uma forma de conceber a cultura (e, ao mesmo tempo, a sociedade) a partir de uma política e uma sensibilidade geo-historicamente marcadas (ver

112 No controverso artigo "Idéias fora do lugar", Schwarz já indicava a peculiaridade da formação cultural brasileira: apenas nos reconheceríamos por essa espécie de "torcicolo cultural" (2000 [1977]: 25); isso quer dizer que a análise do local só se efetiva com a análise e a crítica do global: "para analisar a originalidade nacional, sensível no dia-a-dia, fomos levados a refletir sobre o processo de colonização em seu conjunto, que é internacional. $O$ tic-tac das conversões e reconversões do liberalismo e favor é o efeito local e opaco de um mecanismo planetário" (2000 [1977]: 30). Creio que esse artigo, que vem sendo objeto de debates até hoje (ver, por exemplo, Franco, 1983; Bosi, 2000; Ricupero, 2008), só ganha sentido quando lido à luz da obra posterior de Schwarz e do contexto intelectual que forneceu aquela "intuição de Brasil", a partir da qual ele lança o olhar sobre a cultura brasileira.

${ }^{113}$ Walter Mignolo tenta mostrar a complementaridade entre a crítica de Frantz Fanon e de autores como Antonio Cândido, Roberto Schwarz e Silviano Santiago, estes especificamente no terreno da crítica cultural. Apesar das evidentes diferenças entre estes autores (diferenças estas que, no terreno acadêmico brasileiro, vêm opondo animosamente seguidores de Santiago e Schwarz), Mignolo aponta que todos eles buscaram, à sua maneira, construir novos centros de enunciação a partir de suas localidades geo-históricas (Mignolo, 2005: 189-190). 
Mignolo, 2005), ou seja, pela condição da modernidade na periferia. Um trabalho de reorientação teórica, como aponta Schwarz, eminentemente interdisciplinar:

\begin{abstract}
"A historiografia da cultura ficou devendo o passo globalizante dado pela economia e sociologia de esquerda, que estudam o nosso 'atraso' como parte da história contemporânea do capital e de seus avanços. Visto do ângulo da cópia, o anacronismo formado pela justaposição de formas da civilização moderna e realidades originadas na colônia é um modo de não-ser, ou ainda, a realização vexatoriamente imperfeita de um modelo que está alhures. Já o crítico dialético busca no mesmo anacronismo uma figura de atualidade e de seu andamento promissor, grotesco ou catastrófico" (Schwarz, 2006 [1987]: 47; destaque no original).
\end{abstract}

Por certo, no campo da crítica da cultura, avançou-se mais uma demonstração do potencial crítico daquela intuição de Brasil; uma intuição que, em essência, constitui uma forma de proceder a uma crítica à modernidade capitalista a partir de sua periferia - e que ganha ainda maior sentido, como espero ter demonstrado, frente às discussões correntes acerca da constituição coletiva de ciências sociais e humanas pós-coloniais. 


\title{
Considerações finais
}

\begin{abstract}
"O homem colonizado que escreve para o seu povo, quando utiliza o passado, deve fazê-lo com a intenção de abrir o futuro, convidar para a ação, fundar a esperança. Mas para garantir a esperança, para Ihe dar densidade, é preciso participar da ação, engajar-se de corpo e alma no combate nacional. Pode-se falar de tudo, mas quando se decide falar dessa coisa única na vida de um homem, que é o fato de abrir o horizonte, de trazer a luz para si, de pôr de pé a si mesmo e ao seu povo, então é preciso colaborar muscularmente"
\end{abstract}

Frantz Fanon, (2005 [1961]: 266-267)

Este trabalho procurou descrever uma arena de disputas sobre os pressupostos a partir dos quais se podem narrar os dilemas da modernidade periférica, por um lado, e da modernidade em geral, por outro. A idéia de uma arena de disputas, a meu ver, permite que este trabalho guarde distância de algumas críticas pós-coloniais (e, na verdade, de inúmeras teorias críticas à modernidade) que procuram dar enorme primazia analítica aos processos de dominação - como se o fazer crítico fosse mais uma descrição da catástrofe vigente do que uma análise das tensões do real e de como essas tensões apontam, eventualmente, para formas pensar e, no limite, de viver que se opõem à situação vigente. Com isso, este trabalho busca afastar-se de uma crítica anti-eurocêntrica que entende o ocidental como essencialmente incapaz de emitir discursos não essencialistas sobre o não-ocidental, ou de uma crítica pós-colonial que entende o exercício crítico antieurocêntrico como algo idêntico a uma crítica da metafísica ocidental.

Não se deve, contudo, tomar a imagem dessa arena como o espaço em que duas concepções de mundo se encontram em disputa - de um lado "pensadores eurocêntricos", carregando em suas costas o fardo do imperialismo e de todas as formas de dominação próprias a um capitalismo mundial assimétrico, e de outro lado "pensadores anti-eurocêntricos" ou "pós-coloniais", emissores de mensagens de libertação epistêmica e política. Essa imagem é simplista e nem de longe consegue dar conta da complexa dinâmica de reapropriação dos discursos eurocêntricos em condições periféricas e da formulação de alternativas para a análise da modernidade nessas sociedades - como espero ter ao menos esboçado neste trabalho. 
Essa imagem maniqueísta esconde duas realidades fundamentais. A primeira delas é que a estrutura de atitudes e referências eurocêntricas foi utilizada e reconstruída em contextos muito diversos. Os casos do Brasil e das sociedades árabes e muçulmanas, tratados aqui, ilustram essa diversidade. No primeiro caso, essa estrutura buscou solucionar teórica e politicamente os dilemas de uma sociedade que nasce ligada ao capitalismo mundial em sua constituição, sendo ao mesmo tempo o seu outro e parte do mesmo, sem o qual as benéfices da civilização não se poderiam acumular no centro. Nesse sentido, ela serviu para tematizar uma posição de dupla subordinação, como vimos: frente ao europeu colonizador (já que nos formamos como colônia) e de Portugal, como metrópole colonizadora, frente às demais potências colonizadoras, uma vez que nossos pensadores sociais destacaram inúmeras vezes a precariedade do "iberismo" como plataforma para um processo civilizador. No caso muçulmano, trata-se de uma apropriação levada a cabo para pensar, inicialmente, a crise dessas sociedades ao longo dos últimos três séculos e, mais recentemente, no período pós-colonial durante o qual o diagnóstico sobre o fracasso da modernização dessas sociedades tornou-se comum em todo o espectro político. Em ambos os casos, essa estrutura de atitudes e referências prestou-se à elaboração de teorias e interpretações modernizadoras, para as quais a meta política fundamental deveria ser a eliminação dos inúmeros bloqueios ao moderno que essas sociedades, ou setores fundamentais dela, portariam de forma essencial.

A segunda realidade escondida por uma consideração maniqueísta, relembro, é que as leituras sobre essas sociedades derivadas de alguma forma de apropriação daquela estrutura de atitudes e referências eurocêntricas não são mentiras grosseiras, falsificações elementares do real ou concepções pré-científicas acerca da história dessas sociedades, mas elas representam uma das formas de narrar a experiência contraditória de modernização e da modernidade, em sociedades que não ocuparam um lugar privilegiado na reflexão de autores clássicos da moderna sociologia. Trata-se de um conjunto de imagens, como vimos, ao mesmo tempo "indispensável" - e não é por menos que ele é mobilizado nos mais diversos contextos periféricos e pós-coloniais - e "insuficiente", sobretudo por não se ater aos elementos de dominação de classe e ao caráter periférico da formação dessas sociedades. 
Nesse sentido, fica aqui a observação de que este trabalho deixa como questão em aberto uma análise mais detida das formas pelas quais aquelas narrativas eurocêntricas são apropriadas pelas elites dessas sociedades para a constituição de ideologias modernizadoras que não questionem estruturas de classe altamente desiguais e com fortes traços "tradicionais" - para usar o linguajar que busco aqui criticar. Se as idéias não flutuam no ar e não possuem uma potência própria de realização, como se tentou argumentar aqui, será preciso entender, em trabalhos futuros, as maneiras pelas quais aquela estrutura de referências ganha relevância e torna-se, em inúmeros casos, parte de um aparato de hegemonia de classe - não habitando apenas as peças de maior erudição social, mas, sim, fazendo parte das análises mais corriqueiras e politicamente influentes nas dinâmicas dessas sociedades periféricas.

Dessa maneira, procurou-se mostrar que essas imagens acerca do "atraso" ganham maior relevância analítica e crítica a partir de uma espécie de redefinição da unidade de análise, possibilitando uma reestruturação categorial que abra espaço para que a crítica à modernidade periférica constitua uma crítica à modernidade global. Nessa rotação, tenta-se superar o dualismo da estrutura de referências eurocêntricas, primeiramente, por meio da perspectiva das múltiplas modernidades, um primeiro momento lógico, em direção à consideração do caráter global e contraditório da modernidade capitalista. De uma estrutura dicotômica, passamos pela diversidade e, por fim, propomos o terreno da totalidade e da contradição como aquele em que melhor se assentam as críticas à modernidade a partir da periferia que foram descritas - críticas advindos de tradições teóricas diversas, constituindo o próprio programa interparadigmático pós-colonial, como este foi aqui apresentado.

A partir desse esboço de programa crítico, creio ser possível pensar uma das possíveis chaves para uma leitura proveitosa de teóricos sociais periféricos. Acredito que tais autores, como tentei sugerir nos dois últimos capítulos, devem ser lidos como testemunhas de disputas e impasses ainda não resolvidos nessas sociedades, dos quais as forças sociais do presente ainda são herdeiras. Com isso, espero ter sugerido, de alguma forma, que o estudo do pensamento social em nações periféricas adquire maior relevância quando serve de ponto de partida para uma reflexão sobre nossos dilemas sociais e sobre o estado de nossas ciências sociais no presente - e não como estudo de uma espécie de cânone local que, 
sendo apenas mais um entre os milhares de "objetos" a disposição de historiadores e cientistas sociais, é dissecado como testemunha de um passado que já não nos diz respeito. Nesse sentido, esses textos devem servir como pontos de partida para a reflexão intelectual e para a práxis política voltadas para o presente, e não como pontos de chegada de trajetórias acadêmicas, individuais ou coletivas. Para além disso, creio que esse tipo de estudo é bastante beneficiado quando contraposto e comparado a problemas semelhantes enfrentados por outras nações periféricas: estudar comparativamente o pensamento social de nações periféricas talvez seja mais um passo adiante na desprovincialização de nossas ciências sociais.

Esses movimentos foram esboçados ao longo desta dissertação, e certamente esse esboço está longe de oferecer respostas concretas sobre como proceder essa crítica às formas do pensar eurocêntrico - e não é a isto que este trabalho se propôs. As tensões e proximidades foram aqui apenas esboçadas, em diálogo com uma série de teóricos críticos contemporâneos, advindos de disciplinas diversas - e, em geral, proponentes de Ciências Sociais e Humanas interdisciplinares, como se tentou de forma muito introdutória fazer aqui. Talvez haja um abuso, nesta proposta, da idéia de "diálogo", uma vez que ela pode ser vista como demasiadamente imprecisa ou aberta, não permitindo um real enfrentamento dos problemas colocados pelos textos, quando tratados em suas nuances. Contudo, creio que a idéia de um "diálogo" entre tradições teóricas que buscaram criticar o caráter eurocêntrico dos sistemas modernos de saber e de poder não pode ser substituída por um rigor textual extremado que se foque apenas nas distâncias supostamente inconciliáveis entre os projetos intelectuais, digamos, da tradição marxista e dos estudos pós-estruturalistas. A estratégia aqui, por mais aberta que possa parecer, foi tentar sugerir, mais do que demonstrar, o potencial de um projeto coletivo de descolonização das estruturas do saber na narração da modernidade, trilhado por meio de uma crítica à modernidade lançada a partir de sua periferia.

Porém, uma outra questão importante ainda fica em aberto, referente a como avançar o tipo de crítica que aqui se propõe. Esta questão refere-se ao próprio conceito de crítica, na forma como ele foi levantado inúmeras vezes ao longo deste 
trabalho. O que é, afinal, uma "teoria crítica" e em que ela se distingue de uma, digamos, "teoria tradicional"? Na verdade, esta é apenas uma formulação mais específica acerca do sentido e das delimitações de um projeto teórico que se propõe como crítico. Evidentemente, esta é uma questão que não poderá ser tratada aqui, ainda mais a esta altura. Por certo, ela é uma fundamental para o pensamento social, ao menos, ao longo do último século, e certamente ainda não se esgotou.

No limite, a questão que fica am aberto refere-se às maneiras pelas quais se pode entender que uma determinada teoria pode ser elaborada, mais uma vez, a partir de um determinado "ponto de vista". A idéia proposta de que uma teoria póscolonial é uma forma de proceder a crítica à modernidade a partir de sua periferia, que tentei delinear por meio de uma série de contribuições teóricas que considero complementares, ainda deixa em aberto o problema de como os discursos teóricos e as teses acadêmicas ecoam disputas de indivíduos, grupos e classes reais. Assim, se, por um lado, creio que esse conceito de crítica aqui apresentado - ou seja, uma tentativa de reinvenção da perspectiva a partir da qual se analisa a modernidade, que busque mostrar que os "atrasos" periféricos devem ser lidos como parte de uma história mundial da modernidade e devem servir como pontos de crítica a esta - encontra-se no terreno de uma descolonização do saber (apesar de não resolver todos os dilemas deste), ele não enfrenta de forma direta o problema da descolonização do poder, para utilizar os termos de teóricos da modernidade/colonialidade.

Mais especificamente, creio que uma questão que ainda não é respondida pela maioria desses discursos críticos que analisei refere-se às formas pelas quais essa descolonização das representações da modernidade deve vir de mãos dadas a uma reconstrução do fazer científico; uma reconstrução que permita aliar progressismo teórico às vozes insurgentes de atores sociais reais que, localizados em uma situação periférica, sustentam os mais pesados fardos dessa modernidade/colonialidade. Nos termos do sociólogo Boaventura de Sousa Santos, essa reinvenção dos conceitos deve vir acompanhada de uma reinvenção do próprio fazer teórico, em direção a um projeto político-intelectual coletivo que tem como pressuposto a necessidade de se "aprender com o Sul" - sendo o "sul" uma metáfora para o sofrimento humano causado pela modernidade capitalista. Um aprendizado que exigiria a reinvenção da emancipação social, permitindo que se vá 
além de uma repetição da teoria crítica produzida no centro e da práxis política e social que ela subscrevera (ver Santos, 2006 e 2007).

Dessa maneira, para que um projeto de crítica pós-colonial ganhe efetividade para além dos eventuais ganhos intelectuais imediatos, creio que ela deva ser um projeto de engajamento com as vozes de atores subalternos insurgentes, de maneira a que se possam recriar, aos poucos, as formas do fazer acadêmico e político. Um engajamento dialógico que permita que esse pensamento tenha relevância social e aponte, junto dessas forças sociais organizadas, para outros paradigmas de vida e de sociedade, para além daquele próprio à modernidade/colonialidade. Um fazer teórico que, ao mesmo tempo, "ajuda as forças em desenvolvimento a se tornarem mais conscientes de si mesmas e, portanto, mais concretamente ativas e operosas" (Gramsci, 2002: 37) e que seja permanentemente reflexivo sobre a sua própria conduta e sobre a relevância em se constituir como elemento dessa práxis social, cujas dimensões estão muito além dos muros da universidade ou de nossas rotinas acadêmicas bem estabelecidas.

Trata-se, é evidente, de uma tarefa de imensas proporções. Entretanto, ela não será e nem poderia ser levada a cabo por indivíduos isolados ou por alguns partidários de determinadas posturas intelectuais. É uma tarefa que passa, no limite, por uma reflexão constante sobre o que significa, hoje, agir "muscularmente", na forma como Frantz Fanon formula o problema. Ou, nos termos de Paulo Freire, trata-se de buscar formas de produção de conhecimentos em que "ação e reflexão, de tal forma solidárias, em uma interação tão radical que, sacrificada, ainda que em parte, uma delas, se ressente, imediatamente, a outra" (Freire, 2007: 89).

Para isso, é fundamental que os proponentes desse tipo de reflexão crítica desenvolvam uma confiança de que os "subalternos podem falar". Suas vozes devem ser entendidas como reivindicações por novas formas de vida e sociedade, mas também como convites a uma reflexão permanente sobre nossos métodos, procedimentos e sobre o sentido do fazer intelectual que se entende como exercício crítico. Dessa maneira, a crítica anti-eurocêntrica, assim como toda teoria crítica, deve buscar refletir sobre as possibilidades e caminhos de realização de uma tarefa que está para além da reconstrução das narrativas da modernidade - no sentido de uma práxis criadora de novas formas de vida que se articulem a novas formas de produção de conhecimento, de maneira que a descolonização do saber e a descolonização do poder se nutram reciprocamente. 


\section{Bibliografia}

ABDEL-MALEK, Anouar (1975). Dialética Social: fundamentos para uma teoria social mundializante. Rio de Janeiro: Paz e Terra.

ABED-KOTOB, Sana (1995). "The Accommodationists Speak: Goals and Strategies of the Muslim Brotherhood of Egypt". International Journal of Middle East Studies 27(3): 321339.

ADORNO, Theodor W. (2008) [1968]. Introdução à Sociologia. São Paulo: Editora UNESP.

AHMAD, Aijaz (2002). Linhagens do Presente. São Paulo: Editora Boitempo.

AJAMI, Fouad (2006). "The Promise of Liberty". Wall Street Journal (Eastern Edition), February 7, 2006.

2003.

(2003). "The Anti-Americans". Wall Street Journal (Eastern Edition), July 3 ,

(2001). "Arabs Have Nobody to Blame But Themselves". Wall Street Journal (Eastern Edition), October 16, 2001.

(1981). The Arab Predicament: Arab Political Thought and Practice Since 1967. New York: Cambridge University Press.

AL-KHAFAJI, Isam (2004). Tormented Births: Passages to Modernity in Europe and the Middle East. London: I.B. Tauris.

(1986). "State Incubation of Iraqi Capitalism". Middle East Report, 86: 4-12.

AL-KHALIL, Samir (1989). The Republic of Fear: The Politics of Modern Iraq. Berkeley: University of California Press.

ALMEIDA, Alberto C. (2007). A cabeça do brasileiro. Rio de Janeiro: Record.

AMADEO, Javier, G. ROJAS (2007). "Marxismo, pós-colonialidade e teoria dos sistemasmundo". Trabalho apresentado no $31^{\circ}$ Encontro Anual da ANPOCS. Disponível em <http://201.48.149.89/anpocs/arquivos/15_10_2007_11_3_38.pdf>.

AMIN, Samir (1976). La Nation Arabe: nationalisme et luttes de classes. Paris: Éditions de Minuit.

ANDAYA, Bárbara W. (1997). "Historicising 'modernity' in Southeast Asia". Journal of the Economic and Social History of The Orient, 40(4): 391-409.

ANDERSON, Lisa (1995). "Democracy in the Arab World: A Critique of the Political Culture Approach". In R. Brynen, B. Korany e P. Noble (eds.), Political Liberalization and Democratization in the Arab World, Vol. 1: Theoretical Perspectives. Boulder: Lynne Rienner. Politics 20(1): 1-18.

(1987). "The State in the Middle East and North Africa". Comparative

ANDERSON, Perry (1985). Linhagens do Estado Absolutista. São Paulo: Editora Brasiliense.

APPIAH, Kwame A. (2003). "Is the 'Post-' in 'Postcolonial' the 'Post-' in 'Postmodern'?". In P. Mongia, Contemporary Postcolonial Theory: A Reader. New York: Oxford University Press.

ARANTES, Paulo Eduardo (2000), Hegel: a ordem do tempo. São Paulo, Hucitec/Polis. (1996). Ressentimento da Dialética. São Paulo: Paz e Terra.

(1992). Sentimento da Dialética na Experiência Intelectual Brasileira. São Paulo: Paz e Terra. 
ARICÓ, José (1982). Marx e a América Latina.Rio de Janeiro, Paz e Terra.

ARON, Raymond (2008). As Etapas do Pensamento Sociológico. São Paulo: Martins Fontes.

ARRUDA, Maria A. do N. (2001). Metrópole e Cultura: São Paulo no Meio Século XX. Bauru: EDUSC.

AVELINO FILHO, George (1990). "Cordialidade e Civilidade em Raízes do Brasil". Revista Brasileira de Ciências Sociais, 12(5): 5-14.

(1987). "As Raízes de 'Raízes do Brasil”". Novos Estudos, 18: 33-41.

AYUBI, Nazih N. (2006). Over-Stating the Arab State: Politics and Society in the Middle East. London: I. B. Tauris.

BARAKAT, Halim I. (1993). The Arab world: society, culture and state. Berkeley: University of California Press.

BARAM, Amatzia (1997). "Neo-Tribalism in Iraq: Saddam Hussein's Tribal Policies 1991-96". International Journal of Middle East Studies 29(1): 1-31.

(1991). Culture, History and Ideology in the Formation of Ba'thist Iraq: 1968-1989. London: Palgrave Macmillan.

(1989). "The ruling political elite in Ba'thi Iraq, 1968-1986: the changing features of a collective profile". International Journal of Middle East Studies 21(4): 447493.

BARBOSA, Muryatan S. (2008). "Eurocentrismo, História e História da África". Sankofa: Revista de História da África e de Estudos da Diáspora Africana, 1: 46-62.

BARTOLOVICH, Crystal (2005). "Global Capital and Transnationalism". In H. Schwarz e S. Ray (eds.), A Companion to Postcolonial Studies. London: Blackwell Publishing.

BARTOLOVICH, Crystal, N. LAZARUS (eds.) (2002). Marxism, modernity, and postcolonial studies. New York: Cambridge University Press.

BASTOS, Élide Rugai (1999). "Pensamento Social da Escola Sociológica Paulista". In S. Miceli (org.), O que ler na Ciência Social Brasileira, 1970-1995, vol. 4. São Paulo: Ed. Sumaré/ANPOCS.

BATATU, Hanna (1979). The Old Social Classes and the Revolutionary Movements of Iraq. Princeton: Princeton University Press.

BELLIN, Eva (2004). "The Robustness of Authoritarianism in the Middle East: Exceptionalism in Comparative Perspective". Comparative Politics 36(2): 139-158.

(2000). "Contingent Democrats: industrialists, labor, and democratization in late-developing countries". World Politics, 52: 175-205.

BHABHA, Homi K. (1998). O Local da Cultura. Belo Horizonte: Ed. UFMG.

BILL, James A., R. SPRINGBORG (1990). Politics in the Middle East. Glenview, IL.: Scott.

BLAUT, James (2000). Eight Eurocentric Historians. New York: Guilford Press.

BOBBIO, Norberto (1996). "Grandeza e decadência da ideologia européia". In Norberto Bobbio, Intelectuais e o poder. São Paulo, Editora Unesp.

BOSI, Alfredo (2000) [1992]. Dialética da Colonização. São Paulo: Companhia das Letras.

BRANDÃO, Gildo M. (2007). Linhagens do Pensamento Político Brasileiro. São Paulo: Editora Hucitec.

$231-269$

(2005). "Linhagens do Pensamento Político Brasileiro". DADOS, 48(2):

(2001). "Idéias e Intelectuais: Modos de Usar". Lua Nova, 54: 25-42. 
BRASIL JR., Antonio da S. (2008). "Demora cultural, dilema social e capitalismo dependente: rotações de perspectivas". Trabalho apresentado no Congresso do Projeto Temático Linhagens do Pensamento Político Brasileiro, FFLCH-USP.

BRUMBERG, Daniel (2002). "The trap of liberalized autocracy". Journal of Democracy 13(4): 56-68.

BRYNEN, Rex, B. KORANY, P. NOBLE (eds.) (1995). Political Liberalization and Democratization in the Arab World, Vol. 1: Theoretical Perspectives. London: Lynne Rienner.

BUCK-MORSS, Susan (2000). "Hegel and Haiti". Critical Inquiry, 26(4): 821-865.

CAMPANTE, Rubens Goyatá (2003). "O Patrimonialismo em Faoro e Weber e a Sociologia Brasileira". DADOS, 46(1): 153-193.

CÂNDIDO, Antonio (2007) [1957]. Formação da Literatura Brasileira: Momentos Decisivos. São Paulo: Ouro sobre Azul.

(2006). "O significado de 'Raízes do Brasil'”. In S. B. de Holanda, Raízes do Brasil. São Paulo: Companhia das Letras. Brasileiros, $\mathrm{n} \cong 8$.

(1970). "Dialética da Malandragem". Revista do Instituto de Estudos

CARDOSO, Ciro Flamarion S. (1980). "As concepções acerca do "sistema econômico mundial" e do "antigo sistema colonial"; a preocupação obsessiva com a "extração de excedente". In J. R. do Amaral Lapa (org.), Modos de produção e realidade brasileira. Petrópolis: Vozes.

CARDOSO, Fernando H. (2003) [1962]. Capitalismo e Escravidão no Brasil Meridional. São Paulo: Ed. Civilização Brasileira.

(1993). "Livros que inventaram o Brasil". Novos Estudos, 37: 21-35.

(1979). "'Teoria da Dependência' ou análises concretas de situações de dependência?". In F. H. Cardoso, O Modelo Político Brasileiro. São Paulo: Difel/Difusão Editorial S.A.

(1977). "The consumption of Dependency Theory in the United States". Latin American Research Review, 12(3): 7-24.

(1975). Autoritarismo e Democratização. Rio de Janeiro: Paz e Terra.

(1972) [1964]. Empresário Industrial e Desenvolvimento Econômico. São

Paulo: Difel.

CARDOSO, Fernando H., E. FALETTO (2004) [1969]. Dependência e Desenvolvimento na América Latina. Rio de Janeiro: Civilização Brasileira.

CEVASCO, Maria E. (2003). Dez Lições sobre Estudos Culturais. São Paulo: Boitempo.

COHN, Gabriel (1999). "A Revolução Burguesa no Brasil". In L. D. Mota (org.), Introdução ao Brasil: um banquete no trópico. São Paulo: Editora Senac São Paulo.

CORONIL, Fernando (2000). "Naturaleza del poscolonialismo: del eurocentrismo al globocentrismo". In E. Lander (org.), La colonialidad del saber: Eurocentrismo y Ciencias Sociales - Perspectivas latinoamericanas. Buenos Aires: CLACSO.

COSTA, Sérgio (2006). "Desprovincializando a Sociologia: a contribuição pós-colonial". Revista Brasileira de Ciências Sociais, 21(60): 117-134.

COUTINHO, Carlos Nelson (2000). "Marxismo e 'imagem do Brasil' em Florestan Fernandes". Disponível em < http://www.acessa.com/gramsci/?page=visualizar\&id $=90>$. 
(1987). "Apresentação". In A. GRAMSCI, A Questão Meridional. Rio de Janeiro: Paz e Terra.

CHAKRABARTY, Dipesh (2002). Habitations of Modernity: essays in the wake of subaltern studies. Chicago: The University of Chicago Press.

(2000). Provincializing Europe. Princeton: Princeton University Press.

CHATTERJEE, Partha (1993). The Nation and its Fragments: Colonial and Postcolonial Histories. Princeton: Princeton University Press.

DAMATTA, Roberto (1997) [1979]. Carnavais, Malandros e Heróis. Rio de Janeiro: Rocco. (1991). A Casa \& a Rua. Rio de Janeiro: Guanabara Koogan S.A.

DEEGAN, H. (1993). The Middle East and Problems of Democracy. Buckingham: Open University Press.

DEMANT, Peter (2007). Choque dos Universalismos: estudos sobre a interação OcidenteIslã. Tese de Livre Docência, Departamento de História, Faculdade de Filosofia Letras e Ciências Humanas, Universidade de São Paulo.

(2004). O Mundo Muçulmano. São Paulo: Contexto.

DERRIDA, Jacques (1979). "Estrutura, Signo e Jogo no Discurso das Ciências Humanas". In J. Derrida, A Escritura e a Diferença. São Paulo: Ed. Perspectiva.

DIAS, Maria O. L. da S. (2002). "Sérgio Buarque de Holanda - Raízes do Brasil". In S. Santiago (org.), Intérpretes do Brasil. Rio de Janeiro: Editora Nova Aguilar.

DIRKS, Nicholas B. (1992). "Castes of Mind". Representations, 37: 56-68.

DIRLIK, Arif (2003). "The Postcolonial Aura: Third World Criticism in the Age of Global Capitalism". In P. Mongia, Contemporary Postcolonial Theory: A Reader. New York: Oxford University Press.

DOSSE, François (2007). História do Estruturalismo, vol. 1. São Paulo, Edusc.

DUBE, Saurabh (2002). "Colonialism, Modernity, Colonial Modernities”. Nepantla, 3(2): 197219.

DUSSEL, Henrique (2000). "Europa, modernidad y eurocentrismo". In E. Lander (org.), La colonialidad del saber: Eurocentrismo y Ciencias Sociales - Perspectivas latinoamericanas. Buenos Aires: CLACSO.

EICKELMAN, D. F., J. PISCATORI (2004). Muslim Politics. Princeton: Princeton University Press.

EICKELMAN, D. (2000). "Islam and the Languages of Modernity". Daedalus, Janeiro de 2000: 119-135.

EISENSTADT, S. N. (2000). "Multiple Modernities". Daedalus, janeiro de 2000: 1-29.

EL-GHOBASHY, Mona (2005). "The Metamorphosis of the Egyptian Muslim Brothers". International Journal of Middle East Studies 37: 373-395.

EL-HASSAN, Hasan Afif (2005). Democracy Prevention in the Arab World: a Study of Democracy Prevention in Egypt. Tese de Doutorado, Department of Political Science, University of Califórnia, Riverside.

ENTELIS, John (1989). Culture and Counterculture in Moroccan Politics. Boulder: Westview Press.

ESPOSITO, John L. (1995). The Islamic Threat: Myth or Reality?. New York: Oxford University Press.

ESPOSITO, John L., J. VOLL (1996). Islam and Democracy. New York: Oxford University Press. 
ESTEVES, Paulo L. M. L. (1998). "Cordialidade e Familismo Amoral: os dilemas da modernização". Revista Brasileira de Ciências Sociais, 13(36).

FANON, Frantz (2005) [1961]. Os condenados da terra. Juiz de Fora: Ed. UFJF.

FAORO, Raymundo (1993). "A aventura liberal numa ordem patrimonialista". Revista USP, 17: 15-29.

(1958). Os donos do poder. Porto Alegre: Editora Globo S.A.

FAROUK-SLUGLETT, Marion e P. SLUGLETT (1991). "The Historiography of Modern Iraq". The American Historical Review 96(5): 1408-1421.

(1983). "The Transformation of Land Tenure and Rural Social Structures in Central and Southern Iraq, c. 1870-1958". International Journal of Middle East Studies, 15: 491-505.

FERNANDES, Florestan (2008) [1964]. A Integração do Negro na Sociedade de Classes, 2 volumes. São Paulo: Editora Globo. (2006) [1975]. Revolução Burguesa no Brasil. São Paulo: Globo.

(1972). "O Estudo sociológico do subdesenvolvimento econômico". In F. Fernandes, Sociedade de Classes e Subdesenvolvimento. Rio de Janeiro: Zahar Editores, 2aedição.

FOUCAULT, Michel (2007). As palavras e as coisas. São Paulo, Martins Fontes.

(1977). Vigiar e Punir. Petrópolis: Vozes.

FRANCO, Maria Sylvia de C. (1983). Homens Livres na Ordem Escravocrata. São Paulo: Ed. Kairos, $3^{\mathrm{a}}$ edição.

(1976). "As idéias estão em seu lugar". Cadernos de Debate, 1.

FREIRE, Paulo (2007). Pedagogia do Oprimido. Rio de Janeiro: Paz e Terra.

FUKUYAMA, Francis (1989). "The End of History". The National Interest, Summer 1989.

GAUSE III, F.G. (1995). "Regional Influences on Experiments in Political Liberalization in the Arab World". In R. Brynen, B. Korany, P. Noble (eds.), Political Liberalization and Democratization in the Arab World, Vol. 1: Theoretical Perspectives. Boulder: Lynne Rienner.

GELLNER, Ernest (2000) [1981]. Muslim society. Cambridge: Cambridge University Press. (1993). Postmodernism, Reason and Religion. London: Routledge.

GERGES, Fawaz (1999). America and Political Islam: Clash of Cultures or Clash of Interests?. Cambridge: Cambridge University Press.

GIANNOTTI, José Arthur (1976). "Notas sobre a categoria 'modo-de-produção' para uso e abuso dos sociólogos". Estudos Cebrap, 17.

GILROY, Paul (2001). O Atlântico Negro. São Paulo : Ed. 34.

GÖLE, Nilüfer (2002). "Islam in Public: New Visibilities and New Imaginaries". Public Culture, 14(1): 173-190.

91-117.

(2000). "Snapshots of Islamic Modernities". Daedalus, Janeiro de 2000:

(1993). Musulmanes et Modernes: voile et civilisation en Turquie. Paris: Éditions La Découverte.

GRAMSCI, Antonio (2002). Cadernos do Cárcere, vol. 5: O Risorgimento/Notas Sobre a Históra da Itália. Rio de Janeiro: Civilização Brasileira.

(1987). A Questão Meridional. Rio de Janeiro: Paz e Terra. 
GRAN, Peter (1996). Beyond Eurocentrism: A New View of Modern World History. New York: Syracuse University Press.

HABERMAS, Jürgen (2002). O Discurso Filosófico da Modenidade: doze lições. São Paulo: Martins Fontes.

(2001). A constelação pós-nacional: ensaios políticos. Littera Mundi.

14.

(1981). "Modernity versus Post-Modernity". New German Critique, 22: 3-

HALL, Stuart (1996). "When was 'the post-colonial'? Thinking at the limit". In I. Chambers, L. Curtis (eds.), The Post-Colonial Question. New York: Routledge.

(1992). "The West and the Rest: discourse and power". In S. Hall e B. Gieben (eds.), Formations of Modernity. Cambridge: Polity Press/ Open University.

HALLIDAY, Fred (2004). "9/11 and Middle Eastern Studies past and future: revisiting Ivory towers on sand". International Affairs 80(5): 953-962.

(2003). Islam and the Myth of Confrontation: religion and politics in the Middle East. London: I.B. Tauris.

(1995). "The Politics of 'Islam': a second look". British Journal of Political Science 25(3): 399-417. 20(2): 145-163.

HARDING, Sandra (1987). "Introduction: is there a feminist method?". In S. Harding (ed.), Feminism and Methodology. Bloomington: Indiana University Press.

HARTSOCK, Nancy (1987). "The Feminist Standpoint: developing the ground for a specially feminist historical materialism". In S. Harding (ed.), Feminism and Methodology. Bloomington: Indiana Universoty Press.

HASSAN, Gubara S. (2001). "Europe and Radical Islam: Confrontation, Accommodation or Dialogue?". Disponível em <http://www.kunstnetzwerk.at/LO/ fundamentalism.pdf>.

HEGEL, Georg W. F. (1991). A razão na história. Lisboa, Edições 70.

(1952). The Philosophy of History. Chicago: The University of Chicago/ Encyclopedia Britannica.

HIRSH, Michael (2004). "Bernard Lewis revisited". Washington Monthly, novembro de 2004. Disponível em <http://www. washingtonmonthly.com/features /2004/0411.hirsh.html>.

HOBSBAWM, Eric (1977). A Era das Revoluções. São Paulo: Ed. Paz e Terra.

HOLANDA, Sérgio Buarque de (2006) [1936]. Raízes do Brasil. São Paulo: Companhia das Letras.

HOURANI, Albert (2006). Uma história dos povos árabes. São Paulo: Companhia das Letras.

(2005). O Pensamento Árabe na Era Liberal, 1798-1939. São Paulo: Companhia das Letras.

HUDSON, Michal C. (2001). "The Middle East". PS: Political Science and Politics, 34(4): 801804.

(1995). "The Political Culture Approach to Arab Democratization: The Case for Bringing it Back in, but Carefully". In R. Brynen, B. Korany, P. Noble (eds.), Political Liberalization and Democratization in the Arab World, Vol. 1: Theoretical Perspectives. Boulder: Lynne Rienner.

HUNTINGTON, Samuel (1993). "The Clash of Civilizations". Foreign Affairs, summer. 
(1991). The Third Wave: Democratization in the Late Twentieth Century. Norman: University of Oklahoma Press.

IANNI, Octavio (2004) [1965]. Estado e Capitalismo. São Paulo: Editora Brasiliense. (1989). "A Sociologia e o Mundo Moderno". Tempo Social, 1(1): 7-27.

IRWIN, Robert. (2008), Pelo amor ao saber: os orientalistas e seus inimigos. São Paulo: Editora Record.

JANI, Pranav (2002). "Karl Marx, Eurocentrism and the 1857 revolt in British India". In C. Bartolovich, N. Lazarus (eds.), Marxism, modernity, and postcolonial studies. New York: Cambridge University Press.

JAY, Martin (1984). Marxism and Totality: The Adventures of a Concept from Lukács to Habermas. Cambridge: Polity Press.

KARSH, Efraim, I. RAUTSI (1991). Saddam Hussein: a political biography. New York: Grove Press.

KAYA, Ibrahim (2004). "Modernity, openness, interpretation: a perspective on multiple modernities". Social Science Information, 43(1): 35-57.

KEDOURI, Elie (1992). Democracy and Arab Political Culture. Washington, D.C.: Washington Institute for Near East Policy.

KEPEL, Gilles (1993). Le prophéte et le pharaon: aux sources des mouvements islamistes. Paris: Le Seuil.

KHALIDI, Rashid (2005). Resurrecting Empire: Western Footprints and America's Perilous Path in the Middle East. Boston: Beacon Press.

KNEI-PAZ, Baruch (2001). The Social and Political Thought of Leon Trotsky. Oxford: Clarendon Press.

KNÖBL, Wolfgang (2006). "Max Weber, as Múltiplas Modernidades e a Reorientação da Teoria Sociológica". Dados, 49(3): 483-509.

KOMBARGI, Asma Bohsali (1998). The Politics of Islamists in Algeria, Egypt and the Sudan. Tese de Doutorado, Department of Political Science, University of Houston.

KRAMER, Martin (1999). "Bernard Lewis". In Encyclopedia of Historians and Historical Writing. London: Fit Dearborn. Disponível em <http://www.geocities.com/ martinkrame rorg/BernardLewis.htm>.

KUPER, Gina Z. (1989). La dominación patrimonial en la obra de Max Weber. México, DF: Fondo de Cultura Económica.

LAHUERTA, Milton (2005). "Em busca da formação social brasileira: marxismo e vida acadêmica". Perspectivas, 28: 157-186.

LANDER, Edgardo (2000). "Ciências Sociales: saberes coloniales y eurocéntricos". In E. Lander (org.), La colonialidad del saber: Eurocentrismo y Ciencias Sociales Perspectivas latinoamericanas. Buenos Aires: CLACSO.

LANGOHR, Vickie (2004). "Too Much Civil Society, Too Little Politics: Egypt and Liberalizing Arab Regimes". Comparative Politics, 36(2): 181-204.

LEWIS, Bernard (2004). A crise do Islã: Guerra Santa e Terror Profano. Rio de Janeiro: Jorge Zahar Ed..

Ed.

(2002). O que deu errado no Oriente Médio?. Rio de Janeiro: Jorge Zahar

(1996). O Oriente Médio: do advento do cristianismo aos dias de hoje. Rio de Janeiro: Jorge Zahar Ed. 
(1996). "Islam and Liberal Democracy". Journal of Democracy, 7(2): 52-63.

(1993). "The Question of Orientalism". In Islam and the West. New York: Oxford University Press. Disponível em: <http://www.dartmouth.edu/ rel8/ Dpndtdocs/>.

(1990). "The roots of Muslim rage". Athlantic Monthly, September 1990.

Press.

(1988). The Political Language of Islam. Chicago: University of Chicago

LINHARES, Maria Yedda Leite (2000). "Descolonização e lutas de libertação nacional". In D. A. Reis Filho, J. Ferreira e C. Zenha (orgs.), O século XX. O tempo das dúvidas, vol. 3. Rio de Janeiro: Civilização Brasileira

LOCKMAN, Zachary (2005). "Critique from the Right: The Neo-Conservative Assault on Middle East Studies". The New Centennial Review, 5(1): 63-110.

LOVE, John (2000). "Max Weber's Orient". In S. Turner (ed.), The Cambridge Companion to Max Weber. Cambridge: Cambridge University Press.

LOVE, Joseph L. (1998). A Construção do terceiro Mundo. São Paulo: Paz e Terra.

LÖWY, Michael (2007). As Aventuras de Karl Marx contra o Barão de Münchhausen. São Paulo: Cortez, 9ª edição.

(1998). "A Teoria do desenvolvimento desigual e combinado". Revista Outubro, 1(1): 73-80.

LUCIANI, Giacomo (1988). "Economic Foundations of Democracy and Authoritarianism: the Arab World in Comparative Perspective". Arab Studies Quarterly, 10(4): 457-475.

LUKÁCS, Georg (2003) [1922]. História e Consciência de Classe. São Paulo: Martins Fontes.

LUST-OKAR, Ellen (2004). "Divided They Rule: The management and Manipulation of Political Opposition". Comparative Politics, 36(2): 159-180.

MAHMOOD, Saba (2005). Politics of Piety. Princeton: Princeton University Press.

MARR, Phebe (2004). Modern History of Iraq. Boulder: Westview.

MARSOT, Afaf Al-Sayyid (1985). A short history of Modern Egypt. Cambridge: Cambridge University Press.

MARTINS, José de Souza (2004). O cativeiro da terra. São Paulo: Ed. Hucitec, 8ª edição.

MARX, Karl (1975). Formações Econômicas Pré-Capitalistas. Rio de Janeiro: Paz e Terra.

MENDONÇA, Kátia M. L. (1999). "Faoro e o encontro entre ética e política". Lua Nova, 48: 93-108.

MIGNOLO, Walter D. (2007). "Delinking: the rhetoric of modernity, the logic of coloniality and the grammar of de-coloniality". Cultural Studies, 21: $449-514$.

(2005). "Human Understanding and (Latin) American Interests - the politics and sensibilities of geohistorical locations". In H. Schwarz, S. Ray (eds.), A Companion to Postcolonial Studies. London: Blackwell Publishing.

(2003). Histórias Locais/Projetos Globais: Colonialidade, Saberes Subalternos e pensamento liminar. Belo Horizonte: Editora UFMG.

(2002). "The Geopolitics of Knowledge and the Colonial Difference". The South Atlantic Quarterly, 101(1): 56-96.

(2001). "Coloniality of Power and Subalternity". In I. Rodríguez (ed.), The Latin American Subaltern Studies Reader. Durham and London: Duke University Press. 
(2000). "La colonialidad a lo largo y a lo ancho: el hemisferio occidental en el horizente colonial de la modernidad". In E. Lander (org.), La colonialidad del saber: Eurocentrismo y Ciencias Sociales - Perspectivas latinoamericanas. Buenos Aires: CLACSO.

MITCHELL, Timothy (2000). "The Stage of Modernity". In T. Mitchell (ed.), Questions of Modernity. Minneapolis, London: University of Minnesota Press.

(1991). Colonising Egypt. Berkeley : University of California Press.

MONTESQUIEU, Charles Louis Secondat, Baron de la Brede et de. (1982) [1748]. O Espírito das Leis. Brasília: Editora da UnB.

MOORE, Barrington (1967). The Social Origins of Dictatorship and Democracy: Lord and Peasant in the Making of the Modern World. Boston: Beacon Press.

MOORE-GILBERT, Bart. (1999). Postcolonial Theory: contexts, practices, politics. London: New York.

MORSE, Richard (1989). "A Miopia de Schwartzman”. Novos Estudos Cebrap, 24.

(1988). O Espelho de Próspero: cultura e idéia nas Américas. São Paulo: Companhia das Letras.

NASR, S. V. R. (1999). "European Colonialism and the Emergence of Modern Muslim States". In J. Esposito (ed.), The Oxford History of Islam. New York: Oxford University Press.

NIBLOCK, Tim (1998). "Democratization: a Theoretical and Practical Debate". British Journal of Middle Eastern Studies, 25(2): 221-233.

NIMTZ, August (2002). "The Eurocentric Marx and Engels and other related myths". In C. Bartolovich, N. Lazarus (eds.), Marxism, modernity, and postcolonial studies. New York: Cambridge University Press.

NOVAIS, Fernando A. (2005a) [1979]. Portugal e Brasil na Crise do Antigo Sistema Colonial (1977-1808). São Paulo: Editora Hucitec, 8ª Edição.

(2005b). "A evolução da sociedade brasileira: alguns aspectos do processo histórico da formação social no Brasil”. In F. Novais, Aproximações: estudos de história e historiografia. São Paulo: Cosac Naify.

(1986). "Caio Prado Jr. na historiografia brasileira". In R. Moraes, R. Antunes e V. B. Ferrante (orgs.), Inteligência Brasileira. São Paulo: Brasiliense.

OLIVEIRA, Francisco de (2001). "Pensar com radicalidade e com especificidade". Lua Nova 54(1): 89-95.

(1972). "Crítica à razão dualista”. Estudos Cebrap, 2.

OLIVEIRA, Tâmara Maria de (2007). "Desnaturalização da Modernidade e Diálogo com a Pesquisa Empírica - aportes para discussão de dilemas da modernidade periférica". Trabalho apresentado no $31^{\circ}$ Encontro Anual da ANPOCS.

OWEN, Roger (1992). State, Power and Politics in the Making of the Modern Middle East. London: Routledge.

PAIXÃO, Marcelo Jorge de Paula (2005). Crítica da Razão Culturalista: relações raciais e a construção das desigualdades sociais no Brasil. Tese de doutorado, Programa de PósGraduação em Sociologia, IUPERJ.

PATHAK, Avijit (2006). Modernity, Globalization and Identity. Delhi: AAkar Books.

PIERUCCI, Antônio F. (2003). O desencantamento do mundo: todos os passos do conceito em Max Weber. São Paulo: USP, Curso de Pós-Graduação em Sociologia/ Ed. 34.

PIPES, Daniel (1996). The Hidden Hand: Middle East Fears of Conspiracy. New York: St. 
Martin's Press.

PIVA, Luiz Guilherme (1997). Ladrilhadores e Semeadores: a modernização brasileira no pensamento político de Oliveira Vianna, Sérgio Buarque de Holanda, Azevedo Amaral e Nestor Duarte. Tese de Doutorado, Programa de Pós-Graduação em Ciência Política, USP.

POSUSNEY, Marsha P. (2004). "Enduring Authoritarianism: Middle East Lessons for Comparative Theory". Comparative Politics, 36(2): 127-138.

PRADO JR., Caio (2008) [1942]. Formação do Brasil Contemporâneo. São Paulo: Brasiliense.

(1966). A Revolução Brasileira. São Paulo: Brasiliense.

PRADO, Antonio A. (1998). "Raízes do Brasil e o modernismo". Novos Estudos Cebra, 50: 211-218.

PRYCE-JONES, David (1989). The Closed Circle: An Interpretation of the Arabs. New York, Harper \& Row.

QUIJANO, Aníbal. (2000), "Colonialidad del poder, eurocentrismo y América Latina". In E. Lander (org.), La colonialidad del saber: Eurocentrismo y Ciencias Sociales Perspectivas latinoamericanas. Buenos Aires, FLACSO.

RICUPERO, Bernardo (2008). "Da formação à forma: ainda as idéias for a de lugar". Lua Nova, 73: 59-69.

RICUPERO, Bernardo e G. N. FERREIRA (2005). "Raymundo Faoro e as Interpretações do Brasil". Perspectivas, 28: 37-55.

ROSS, Michael L. (2001). "Does Oil Hinder Democracy?". World Politics 53: 325-351.

ROY, Olivier (1992). L'Échec de I'Islam Politique. Paris: Seuil.

SABRA, Adam (2003). "What is Wrong with What Went Wrong?". Middle East Report Online, <http://www.merip.org/mero/interventions/sabra_interv.html> .

SAID, Edward (2003) [1978]. Orientalism. New York: Vintage Books. Harper's, July.

(2002). "Impossible Histories: Why the Many Islams Cannot be Simplified".

(2001). "The Clash of Ignorance". The Nation, 22 de outubro de 2001. Disponível em <http://www.thenation.com/doc/20011022/said>.

(1995) [1993]. Cultura e Imperialismo. São Paulo: Companhia das Letras.

SALLUM Jr., Brasílio (1999). "Sérgio Buarque de Holanda - Raízes do Brasil". In L. D. Mota (org.), Introdução ao Brasil: um banquete no trópico. São Paulo: Editora Senac São Paulo.

SANTOS, Boaventura de Sousa (2007). "Para além do Pensamento Abissal: das linhas globais a uma ecologia de saberes". Novos Estudos, 79: 71-94.

(2006). A Gramática do Tempo. São Paulo, Editora Cortez.

(2004). "Do pós-moderno ao pós-colonial e para além de um e de outro". Disponível em <http://www.ces.uc.pt/misc/Do_posmoderno_ao_pos-colonial.pdf>.

SAYYID, Bobby S. (2003). A Fundamental Fear: eurocentrismo and the emergence of Islamism. London; New York: Zed Books.

SCHLUCHTER, Wolfgang (1996). Paradoxes of Modernity: Culture and Conduct in the Theory of Max Weber. Stanford: Stanford Unversity Press.

SCHMIDT, Volker H. (2007). "Múltiplas Modernidades ou Variedades da Modernidade". Revista de Sociologia Política, 28: 147-160. 
SCHWARTZMAN, Simon (2003). "A atualidade de Raymundo Faoro". DADOS, 46(2): 207213.

(1989). "O gato de Cortazar". Novos Estudos Cebrap, 25: 191-203.

(1988). "O espelho de Morse". Novos Estudos Cebrap, 22:185-192.

(1982). Bases do Autoritarismo Brasileiro. Rio de Janeiro: Editora Campus.

SCHWARZ, Roberto (2008) [1969]. "Cultura e Política, 1964-1969. In R. Schwarz, O pai de família e outros estudos. São Paulo: Companhia das Letras.

(2006) [1987]. "Pressupostos, salvo engano, de 'Dialética da Malandragem'”. In R. Schwarz, Que horas são?. São Paulo: Companhia das Letras.

(2000) [1977]. "Idéias fora do lugar". In R. Schwarz, Ao vencedor as batatas: forma literária e processo social nos inícios do romance brasileiro. São Paulo: Editora 34/Duas Cidades.

Duas Cidades.

(2000 [1990]). Um mestre na periferia do capitalismo. São Paulo: Ed. 34/

(1998). "Um seminário de Marx". Novos Estudos Cebrap, 50.

SEN, Amartya (2005). The Argumentative Indian. London: Penguin Books.

SHARABI, Hisham (1988). Neopatriarchy: A Theory of Distorted Change in Arab Society. New York: Oxford University Press.

SHLAIM, Avi (1995). War and Peace in the Middle East. New York: Penguin Books.

(1988). "The Impact of US Policy in the Middle East". Journal of Palestine Studies, 17(2): 15-28.

SHLAIM, Avi, Y. SAYIGH (eds.) (1997). The Cold War and the Middle East. New York: Oxford University Press.

SHOHAT, Ella, R. STAM (2006). Crítica da imagem eurocêntrica. São Paulo: Cosac Naify.

SMITH, Christian (s.d.). "On Multiple Modernities: shifting the modernity paragidm". Disponível em <http://www.nd.edu/ csmith22/documents/MultipleModernities. pdf>.

SOLINGEN, Etel (1996). "Quandaries of the Peace Process". Journal of Democracy, 7(3): 139-153.

SOUZA, Jessé (2003). A Construção Social da Subcidadania: para uma sociologia política da modernidade periférica. Rio de janeiro: IUPERJ.

(2000). A Modernização Seletiva: uma reinterpretação do dilema brasileiro. Brasília: Editora UnB.

(1998). "A ética protestante e a ideologia do atraso brasileiro". Revista Brasileira de Ciências Sociais, 13(38).

(1997). Patologias da Modernidade: um diálogo entre Habermas e Weber. São Paulo: Annablume.

SPOHN, Wilfred (2006). "Multiple, Entangled, Fragmented and Other Modernities. Reflections on Comparative-Sociological Research on Europe, North and Latin America". In S. Costa, et. Al (eds.), The Plurality of Modernity: Decentering Sociology. München: Hampp.

STEINMETZ, George (2006). "Decolonizing German Theory: an introduction". Postcolonial Studies, 9(1): 3-13.

TAVARES BASTOS, A. C. (1939). Os Males do Presente e as Esperanças do Futuro. São Paulo: Companhia Ed. Nacional. 
TAVOLARO, Sergio B. F. (2005). "Existe uma modernidade brasileira? Reflexões em torno de um dilema sociológico brasileiro". Revista Brasileira de Ciências Sociais, 20(59): 522.

TAYLOR, Charles, Benjamin LEE (s.d.). "Multiple Modernities Project: modernity and difference". Disponível em <http://www.sas.upenn.edu/transcult/promad.html>.

TRIPP, Charles (2005). A History of Iraq. Cambridge, New York: Cambridge University Press.

TROTSKY, Leon (1977) [1930]. A História da Revolução Russa (1ํvolume). Rio de Janeiro: Paz e Terra.

TURNER, Bryan S. (1994). Orientalism, Postmodernism and Globalism. London: Routledge.

(1989). Capitalismo y Clases en el Medio Oriente. México, DF: Fondo de Cultura Económica.

(1993). "Sociedades Asiáticas". In Tom Bottomore (org.), Dicionário do pensamento marxista. Rio de Janeiro, Jorge Zahar.

VATIKIOTIS, P. J. (1987). Islam and the State. Routledge: London.

VIOTTI DA COSTA, Emília (1978). "A Revolução Burguesa no Brasil". Encontros com a Civilização Brasileira (4).

VITALIS, Robert (1995). When Capitalista Collide: Business Conflict and the End of Empire in Egypt. Berkeley: University of California Press.

WALLERSTEIN, Immanuel (2007). O Universalismo Europeu. São Paulo, Boitempo Editorial.

WEBER, Max (2008). "Introdução". In M. Weber, A Ética Protestante e o Espírito do Capitalismo. São Paulo: Cengage Learning, $2^{2}$ edição.

(2004). A Ética Protestante e o Espírito do Capitalismo. São Paulo: Companhia das Letras.

(1987). "Confucionismo e puritanismo". In G. Cohn (org.) WeberSociologia.São Paulo: Ática.

(1951). The Religion of China: Confucionism and Taoism. Glencoe: Free

Press.

(1999). Economia e Sociedade, vol 2. Brasília, Editora UnB.

WEFFORT, Francisco C. (1971). "Notas sobre a 'Teoria da Dependência': Teoria de Classe ou Ideologia Nacional?". Estudos Cebrap, 1: 2-24.

WERNECK VIANNA, Luiz (1999). "Weber e a Interpretação do Brasil". Novos Estudos Cebrap, 53: 33-47. Janeiro: Revan.

(1997). A Revolução Passiva: iberismo e americanismo no Brasil. Rio de

WICKHAM, Carrie R. (2002). Mobilizing Islam. New York: Columbia University Press.

WITTFOGEL, Karl A. (1957). Oriental Despotism: a comparative study of total power. New Haven, Yale University Press.

YOUNG, Robert (1990). White Mythologies: Writing History and the West. London and New York: Routledge. 